\title{
Techno-Economic Study of an Energy Sharing Network Comprised of a Data Centre and MURBs for Cold Climate
}

\author{
by \\ Adreon Raymond Murphy \\ Bachelor of Engineering in Mechanical Engineering, Queen’s University, 2016 \\ A thesis presented to \\ Ryerson University \\ in partial fulfillment of the \\ requirements for the degree of \\ MASTER OF APPLIED SCIENCE \\ in the Program of \\ Mechanical and Industrial Engineering
}

Toronto, Ontario, Canada, 2018

C) Adreon Raymond Murphy 2018 


\section{Author's Declaration}

I hereby declare that I am the sole author of this thesis. This is a true copy of the thesis including any required final revisions, as accepted by my examiners.

I authorize Ryerson University to lend this thesis to other institutions or individuals for the purpose of scholarly research.

I further authorize Ryerson University to reproduce this thesis by photocopying or by other means, in total or in part, at the request of other institutions or individuals for the purpose of scholarly research.

I understand my thesis may be made electronically available to the public. 


\title{
Abstract \\ Technoeconomic Study of an Energy Sharing Network Comprised of a of Data Centre and MURBs for Cold Climate
}

\author{
Master of Applied Science, 2018
}

Adreon Raymond Murphy

\author{
Mechanical and Industrial Engineering \\ Ryerson University, Toronto, ON, M5B 2K3, Canada
}

Due to their significant internal heat gain resulting from computer server banks, data centres require cooling year-round, creating an opportunity to transport the waste heat to heatdeficient neighbouring buildings. This thesis evaluates the quantity of multi-unit residential buildings (MURBs) that should be connected to a given data centre in order to maximize the portion of shared energy which provides the MURBs' heating energy and the data centre's cooling energy simultaneously. The thesis then evaluates the financial viability and greenhouse gas (GHG) emissions of three different methods with which energy can be shared from a data centre to surrounding MURBs in a community energy network (CEN). The first method, called the Energy Sharing System involves using a heat pump to produce heating and cooling at the same time for the MURBs and the data centre. The second, called the One-Borefield System, has the same energy sharing aspect as the first, with additional heating and cooling coming from geo-exchange. The third method, called the Two-Borefield System, is an innovative approach to geo-exchange, which uses two separate borefields to achieve free cooling, while also incorporating the energy sharing base. The investigation finds that the optimal MURB area that should be connected to a 4 MW cooling load data centre is $110,000 \mathrm{~m}^{2}$ for the Toronto (Canada) climate. The financial analysis shows that the Energy Sharing System was the most profitable, with a $11.9 \%$ 30-year after-tax 
internal rate of return (IRR). This scenario resulted in the most efficient operation, achieving an overall 4.3 COP for heating and free cooling. This scenario would reduce the MURBs' annual heating related emissions by 2289 tonnes $\mathrm{CO}_{2} \mathrm{e}(57 \%)$ and reduce the data centre's annual space cooling related emissions by 80 tonnes $\mathrm{CO}_{2} \mathrm{e}(53 \%)$. 


\section{Acknowledgments}

I would like to thank my supervisor, Dr. Alan Fung, who has guided me in this process and opened me up to many new opportunities. I would also like to thank Catherine Thorn and Adam Alaica at Enwave for their guidance and technical expertise. Lastly, I would like to thank the

Ontario Centre of Excellence, Mitacs Accelerate, Enwave Energy Corporation and the Ryerson Faculty of Engineering for their financial support. 


\section{Table of Contents}

Author's Declaration ....................................................................................................

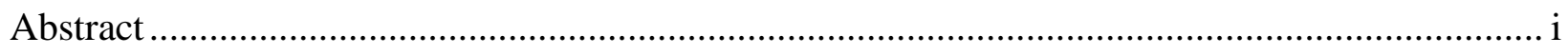

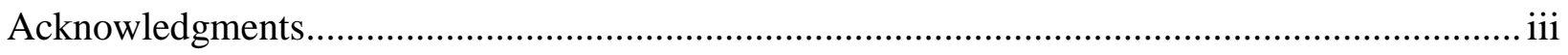

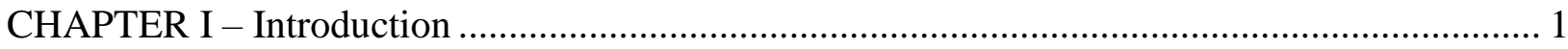

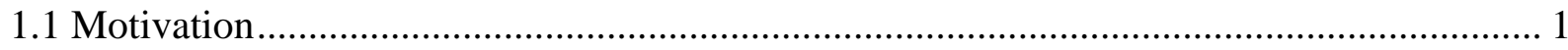

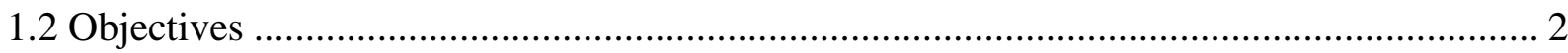

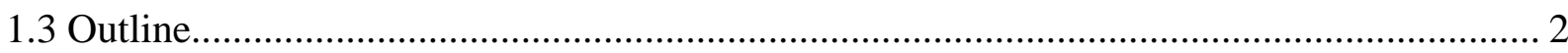

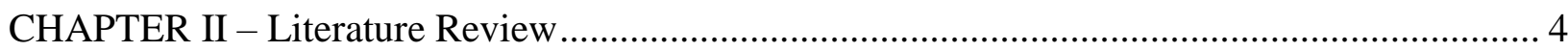

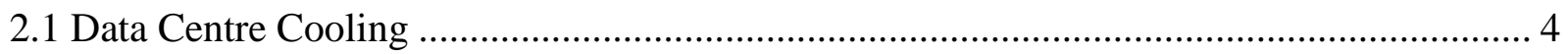

2.1.1 Air and Chilled Water Temperatures Through CRAC Units......................................... 4

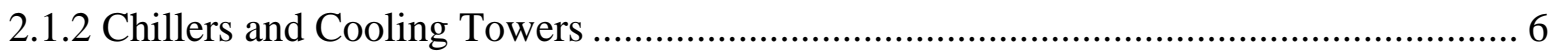

2.1.3 Cooling Load Profiles and Free Cooling ………..................................................... 7

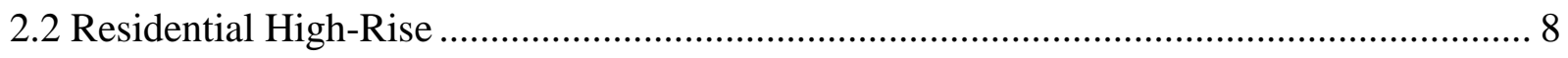

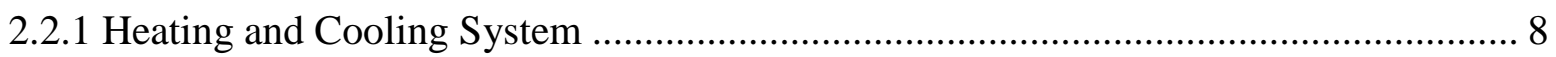

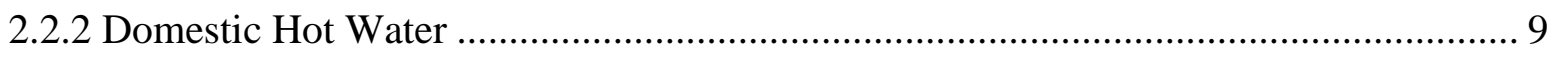

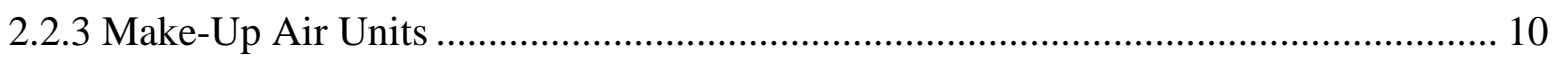

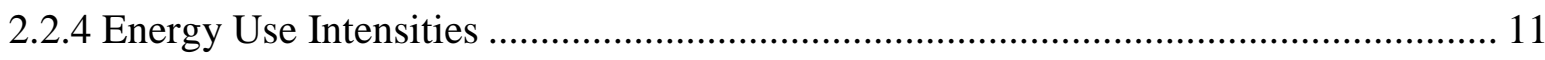

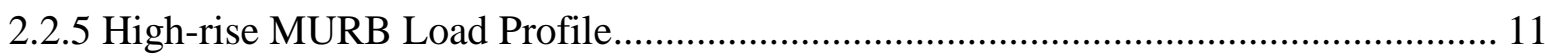

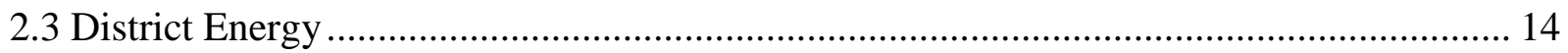

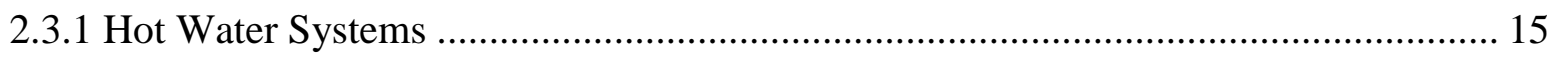

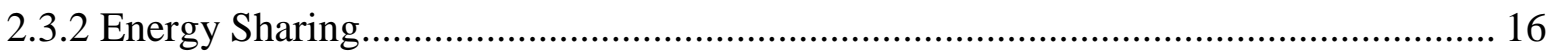

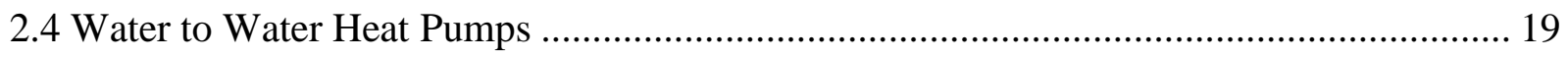

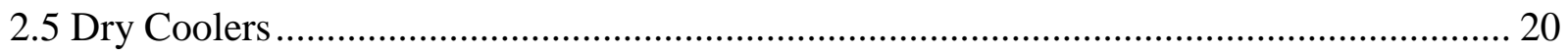

2.6 Ground Source Heat Pumps ..................................................................................... 22

2.7 Existing Data Centre Waste Heat Recovery in District Energy Systems .......................... 27

2.7.1 Open District Heating ..................................................................................... 29

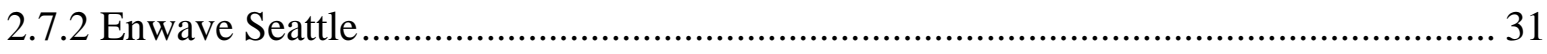

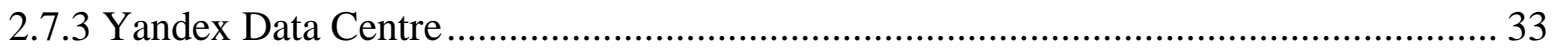

CHAPTER III - Comparison of Energy Sharing Scenarios....................................................... 35

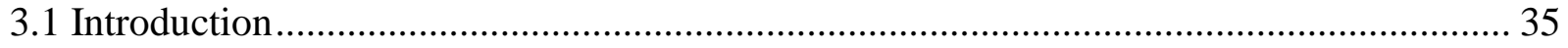

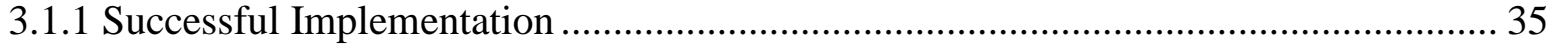

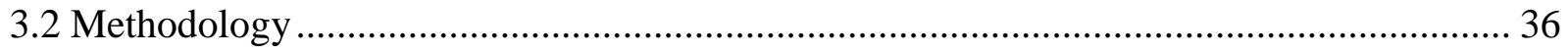

3.3 Scenario 1 - Energy Sharing System.......................................................................... 37 


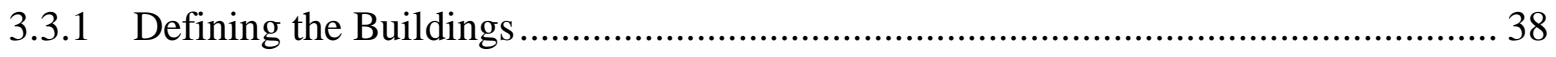

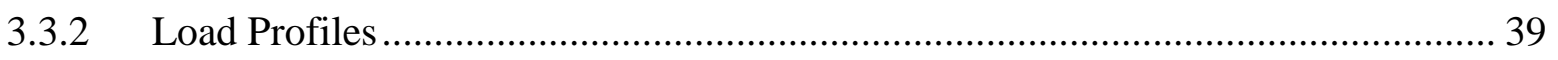

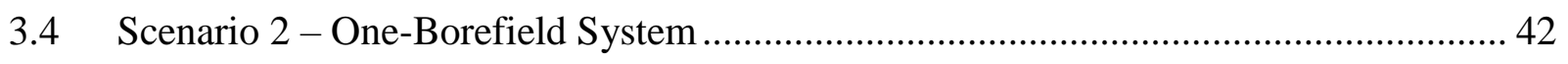

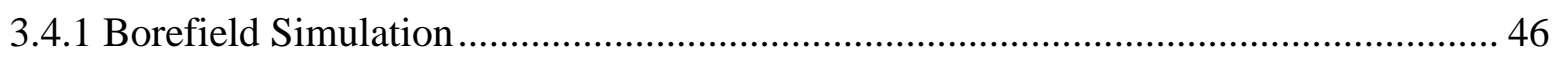

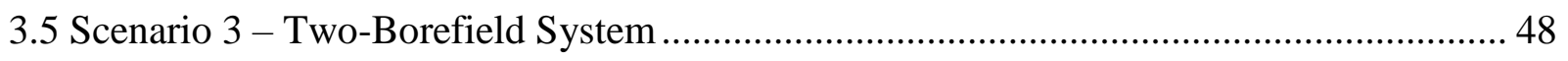

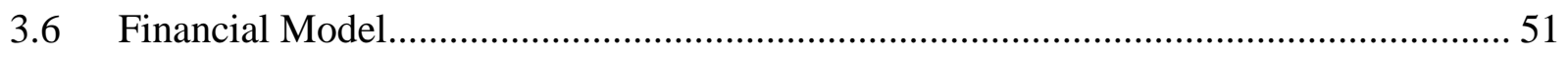

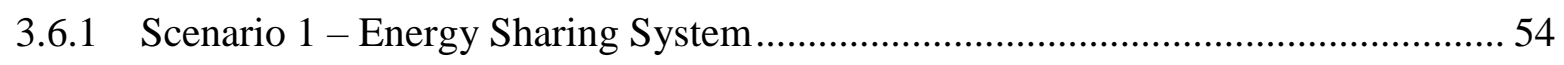

3.6.2 Scenario 2 - One-Borefield System ................................................................. 57

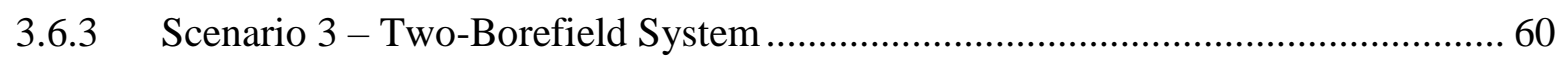

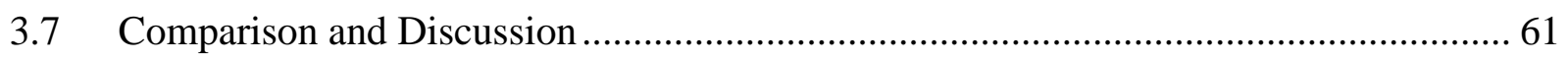

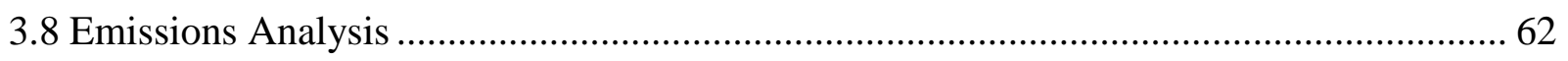

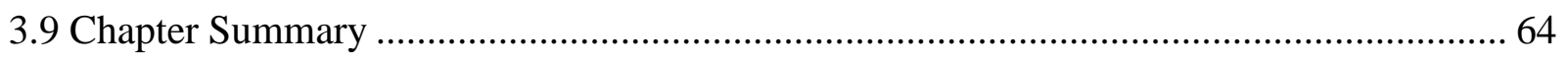

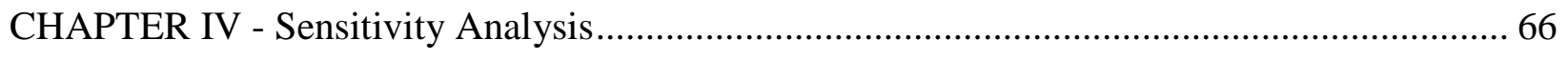

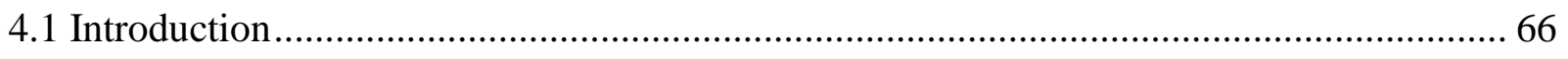

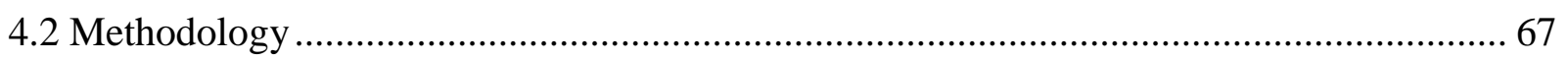

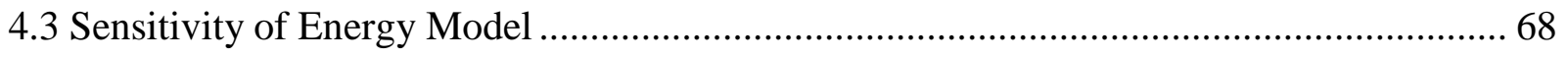

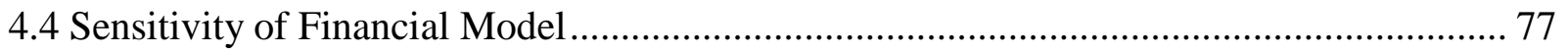

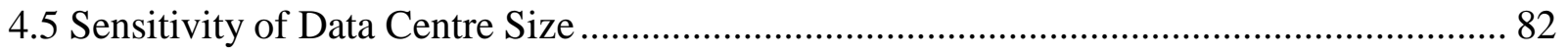

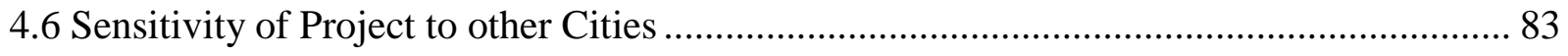

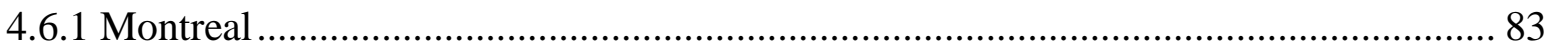

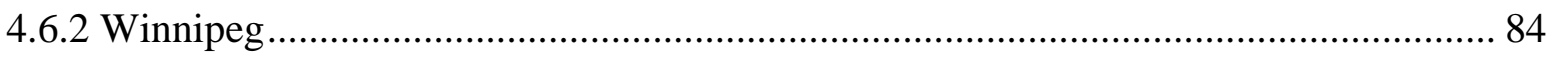

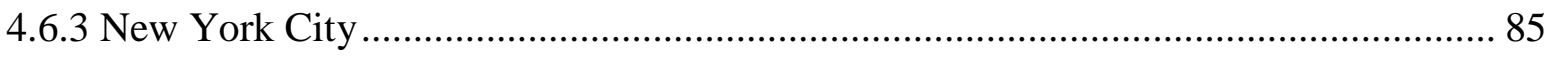

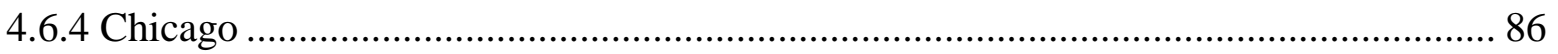

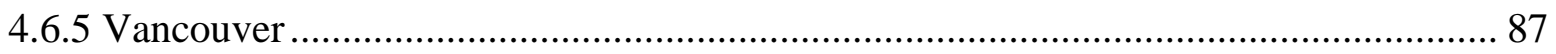

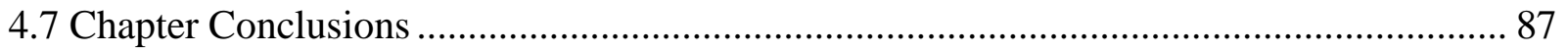

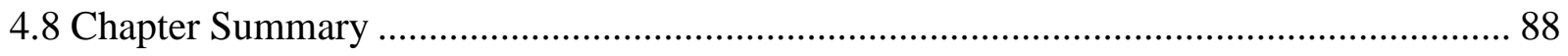

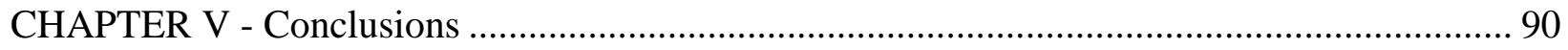

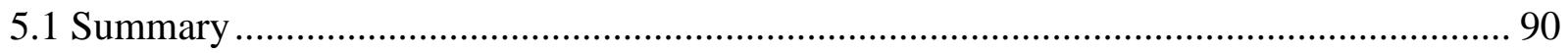

5.1.1 Comparison of Three Different Energy Sharing Systems ....................................... 90

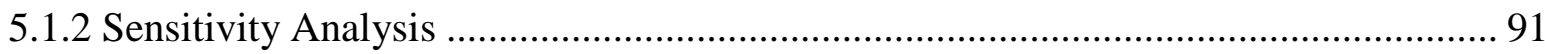

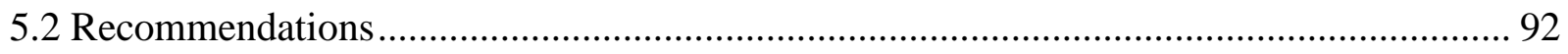

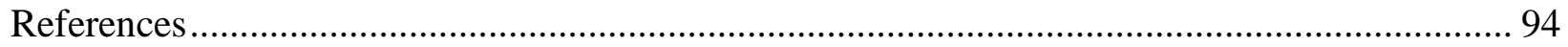

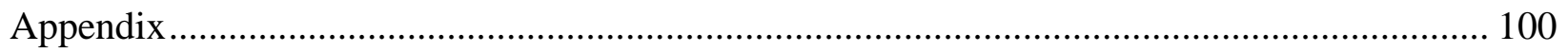

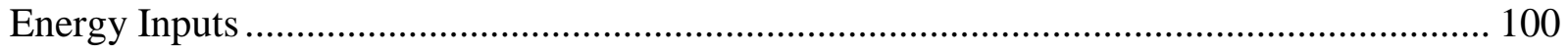




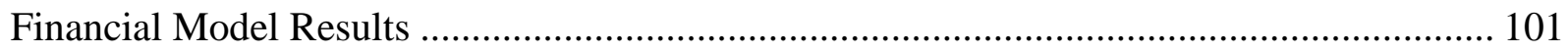

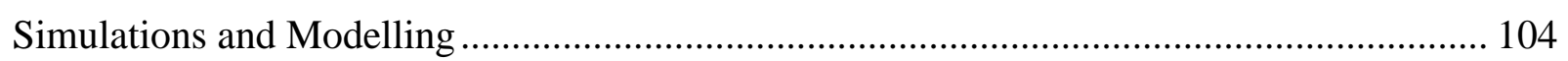

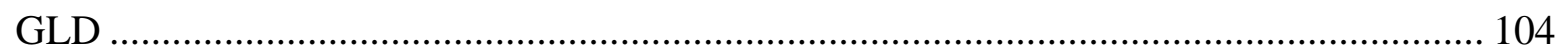

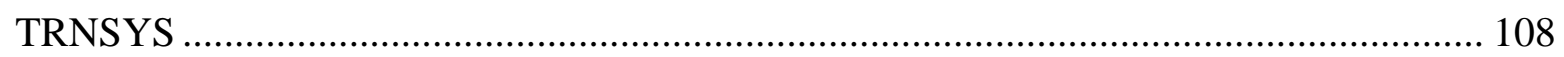




\section{List of Tables}

Table 1: COP of an air cooled chiller for cooresponding outdoor air temperatures (adopted from

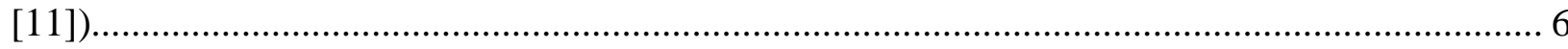
Table 2: Average peak intensities of residential buildings connected to Enwave's district energy system, aggregated by Carson Gemmill [30] .......................................................................... 11 Table 3: Comparison by Davies et al. of using chilled water return or CRAH return air as a waste heat source for district energy systems on an energy, environmental and financial basis [52] .... 29 Table 4: Bosch fan coil correction factors for fan coil output capacity at different heating supply

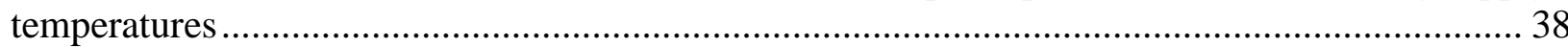

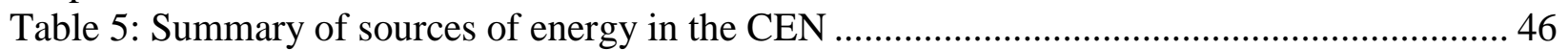

Table 6: Borefield parameters inputted into GLD and TRNSYS for simulation ........................ 47

Table 7: Existing cooling operation parameters for data centre ………………….................... 53

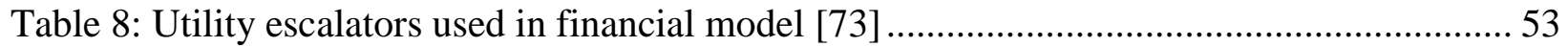

Table 9: Financing cashflow parameters used in financial model [73] ...................................... 54

Table 10: Energy Sharing System (Scenario 1) capital costs used in financial model [73] ......... 54

Table 11: Energy Sharing System operational parameters ........................................................... 56

Table 12: Heating equipment replacement costs for MURBs .................................................... 57

Table 13: One-Borefield System (Scenario 2) capital costs used in financial model [73] ........... 58

Table 14: One-Borefield System operational parameters .......................................................... 59

Table 15: Two-Borefield System (Scenario 3) capital costs used in financial model..................... 60

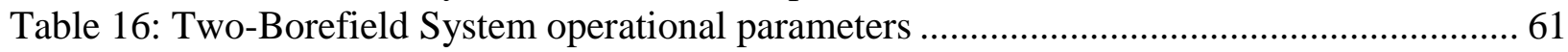

Table 17: Comparison of financial model results for each scenario............................................... 62

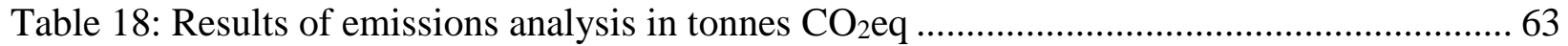

Table 19: Summarization of results from the chilled water supply temperature sensitivity analysis, showing the change in IRR and any other variables which changed during the analysis

Table 20: Summarization of results from the heating water supply temperature sensitivity analysis, showing the change in IRR and any other variables which changed during the analysis

Table 21: Summarization of results from the thermal conductivity sensitivity analysis, showing the change in IRR and any other variables which changed during the analysis ........................... 73 Table 22: Summarization of results from the undisturbed ground temperature sensitivity analysis, showing the change in IRR and any other variables which changed during the analysis ............ 75 Table 23: Summarization of results from the capital cost sensitivity analysis, showing the change in IRR and any other variables which changed during the analysis ............................................. 77 Table 24: Summarization of results from the carbon tax escalation rate sensitivity analysis, showing the change in IRR and any other variables which changed during the analysis ............ 79 Table 25: Summarization of results from the electricity escalation rate sensitivity analysis, showing the change in IRR and any other variables which changed during the analysis ............ 80 Table 26: Summarization of results from the data centre size sensitivity analysis, showing the change in IRR and any other variables which changed during the analysis ................................. 82

Table 27: Parameters changed for Montreal sensitivity analysis................................................... 84

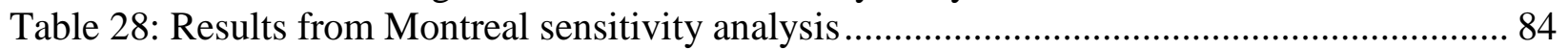

Table 29: Parameters changed for Montreal sensitivity analysis.................................................... 84

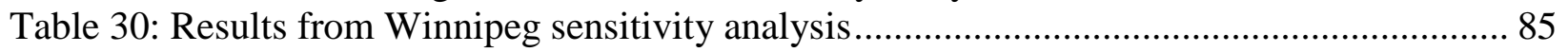


Table 31: Parameters changed for New York City sensitivity analysis.................................. 85

Table 32: Results from New York City sensitivity analysis .............................................. 86

Table 33: Parameters changed for Chicago sensitivity analysis ............................................. 86

Table 34: Results from Chicago sensitivity analysis ........................................................... 86

Table 35: Parameters changed for Vancouver sensitivity analysis ....................................... 87

Table 36: Results from Vancouver sensitivity analysis .................................................... 87

Table 37: Energy consumption breakdown for all equipment in $\mathrm{kWh}$................................... 100

Table 38: "Hot" borefield input parameters used in the Two-Borefield System simulation ...... 109

Table 39: Inputs tab of the "hot" borefield for the Two-Borefield System simulation .............. 111

Table 40: "Cold" borefield input parameters used in the Two-Borefield System simulation .... 111

Table 41: Inputs tab of the "cold" borefield for the Two-Borefield System simulation............. 112

Table 42: Input parameters for the two-stage water to water heat pump connected to the "hot" borefield used in the Two-Borefield System simulation ................................................. 113

Table 43: Input parameters for dry cooler which operates during the winter, used in the Two-

Borefield System simulation....................................................................................... 114

Table 44: Input parameters for dry cooler which operates during the shoulder seasons, used in the Two-Borefield System simulation ........................................................................... 115

Table 45: Weather input parameters used in the Two-Borefield System simulation ................ 117 


\section{List of Figures}

Figure 1: ASHRAE thermal guide lines for data centres [9] ....................................................... 4

Figure 2: Data centre equipment schematic [11] ................................................................. 5

Figure 3: Air flow from CRAH unit through cold, then hot isles in a data centre [13].................. 6 Figure 4: Trane performance data at various condenser water entering temperatures for constant

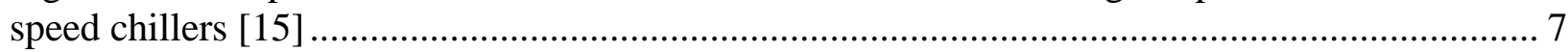

Figure 5: Daikin simulation of 300-ton air-cooled screw chiller with integrated free cooling, showing hourly energy consumption in a data centre over a year [17] ....................................... 8 Figure 6: Recirculation pipe line diagram, showing supply and return from building risers with DHW heater, pump and city water supply [27] 10 Figure 7: Average hourly MURB heating load profile from a building energy model provided by Enwave, showing the percentage of the buildings peak heating which is attributed to domestic hot water (DHW) and the combined space heating and DHW heating load as a percentage of the peak hourly heating load [30] ......................................................................................... 12 Figure 8: Average hourly MURB cooling load profile from a building energy model provided by Enwave, showing the percentage of the buildings peak cooling load at all hours of the year [30]

Figure 9: Heating and cooling load duration curve of one of Enwave's metered residential

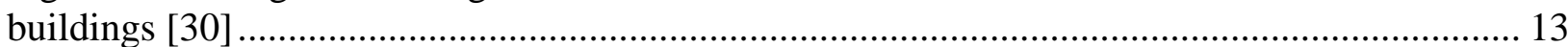

Figure 14: Energy use and $\mathrm{CO}_{2}$ emissions data from Sweden's district energy systems, from 1980

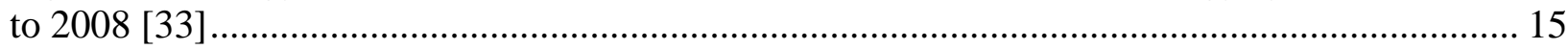

Figure 15: Waste heat temperature of various energy sources that are commonly used in district energy, prepared by FVB Energy [33] .................................................................................. 16 Figure 16: Thermenex Thermal Gradient Header, contained within building mechanical room

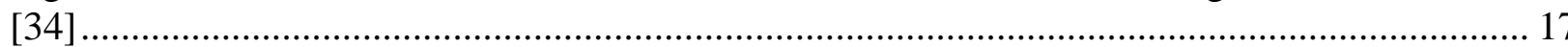

Figure 17: Themenex aquatic centre project, showing resulting natural gas intensity of Thermenex aquatic centre, compared to similar facilities during summer months [36] .............. 18 Figure 18: Themenex aquatic centre project, showing resulting total energy intensity of Thermenex aquatic centre, compared to similar facilities during summer months [36] .............. 18 Figure 19: Example of Thermenex district energy network, incorporating the serpentine, multitemperature pipe [34] .................................................................................................. 19 Figure 20: Heat pump COP versus hot-water supply temperature, with $42^{\circ} \mathrm{F}\left(6^{\circ} \mathrm{C}\right)$ chilled water supply temperature from ASHRAE [38] ........................................................................ 20 Figure 21: Dry cooler, showing fin and tube heat exchanger and fan used to draw air through it

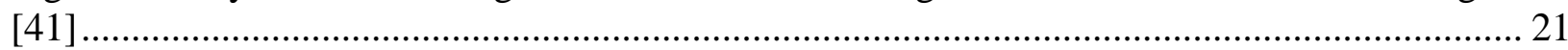
Figure 22: Daikin simulation of 300 ton air-cooled screw chiller, showing energy consumption in a data centre over a year, with various equipment configurations [17] ...................................... 21 Figure 23: Study by Florides and Kalogirou, showing varying temperature with ground depth, indicating that ground temperature becomes constant at greater depths [45] ............................... 22 Figure 24: COMSOL simulation by Johansson of temperature distribution in ground with unloading dry cooler and boreholes at $212 \mathrm{~m}$ depth after 20 years [51]................................... 25 Figure 25: 20-year temperature profile of the mean fluid temperature exiting the borefield, considering an unloading dry cooler and varying borehole lengths [51]................................... 26 Figure 26: 20-year temperature profile of the mean fluid temperature exiting an $85 \%$ balanced,

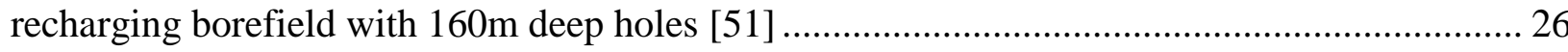


Figure 27: 20-year temperature profile of the mean fluid temperature exiting a 100\% balanced, recharging borefield with varying borehole lengths [51] ................................................ 27

Figure 28: Heat recovery from CRAH return air in data centre, using an air source heat pump

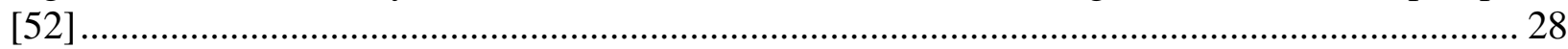

Figure 29: Design for integrating a data centre into a district heating and cooling system [54] .. 30 Figure 30: Design for integrating a data centre into a district heating system [55] .................. 31 Figure 31: Westin Building data centre connected to Enwave Seattle's local district energy

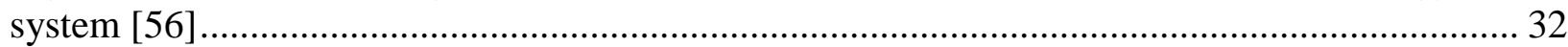

Figure 32: Schematic of Yandex's data centre heat recovery system in Finland [58] ................ 33

Figure 33: Illustration of the proximity of Yandex's data centre to the local district heating

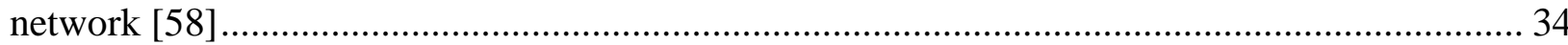

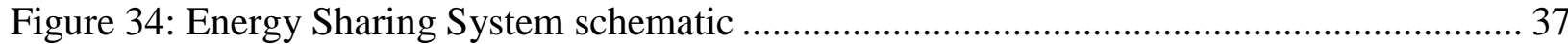

Figure 35: Optimization of MURB area, by finding the maximum percentage of energy sharing

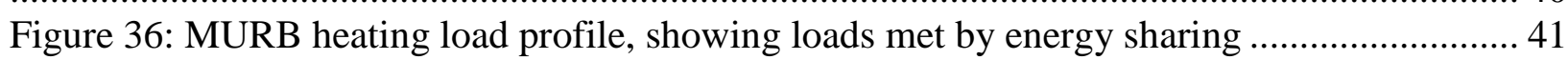

Figure 37: Data centre cooling load profile, showing loads met by energy sharing .................. 41

Figure 38: One-Borefield System (Scenario 2) schematic, simulated in GLD ......................... 42

Figure 39: Optimization of energy met by the CEN for minimized peak provided by the CEN . 43 Figure 40: Results of cost lifecycle cost optimization performed by Nguyen et al. (2014), showing optimal shave factors for several building types in Toronto .................................... 44 Figure 41: MURB heating load profile, showing loads met by energy sharing and geo-exchange

Figure 42: Data centre cooling load profile, showing loads met by energy sharing and geoexchange .......................................................................................................... 45

Figure 43: 20 Year hourly GLD simulation of the One-Borefield System, showing the fluid temperature leaving the borefield and entering the heat pump ........................................... 48

Figure 44: Two-Borefield System (Scenario 3) schematic, simulated in TRNSYS ................... 49 Figure 45: 20-Year hourly TRNSYS simulation of the "hot" borefield in the Two-Borefield System, showing the fluid temperature leaving the borefield and entering the heat pump in red and the average temperature in the entire "hot" borefield volume in green ............................. 50 Figure 46: 20-Year hourly TRNSYS simulation of the "cold" borefield in the Two-Borefield System, showing the fluid temperature leaving the borefield and entering the data centre fan coils in blue and the average temperature in the entire "cold" borefield volume in green .................. 51 Figure 47: 30-year after-tax IRR for each scenario, testing the sensitivity of an 8, 9, 10, 11 and

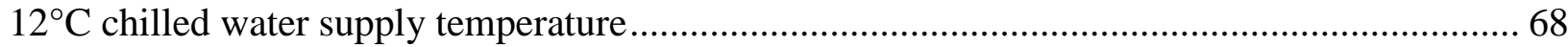
Figure 48: COPs which changed as a result of the chilled water supply temperature sensitivity analysis.

Figure 49: Number of required boreholes which changed as a result of the heating water supply temperature sensitivity analysis ............................................................................. 69 Figure 50: 30-year after-tax IRR for each scenario, testing the sensitivity of a 33, 36, 39, 42 and $45^{\circ} \mathrm{C}$ weighted average heating water supply temperature.

Figure 51: COPs which changed as a result of the heating water supply temperature sensitivity

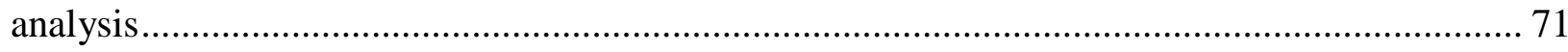
Figure 52: Number of required boreholes which changed as a result of the heating water supply temperature sensitivity analysis 
Figure 53: 30-year after-tax IRR for each scenario, testing the sensitivity of a 2.45, 2.67, 2.94,

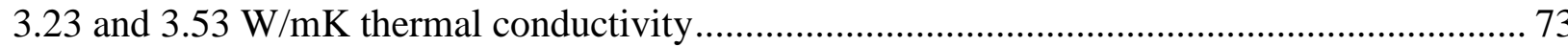
Figure 54: Number of required boreholes which changed as a result of the thermal conductivity sensitivity analysis

Figure 55: 30-year after-tax IRR for each scenario, testing the sensitivity of an 8, 9, 10, 11 and $12^{\circ} \mathrm{C}$ undisturbed ground temperature 75

Figure 56: COPs which changed as a result of the undisturbed ground temperature sensitivity analysis 75

Figure 57: Number of required boreholes which changed as a result of the undisturbed ground temperature sensitivity analysis 76 Figure 58: 30-year after-tax IRR for each scenario, testing the sensitivity of changing the capital

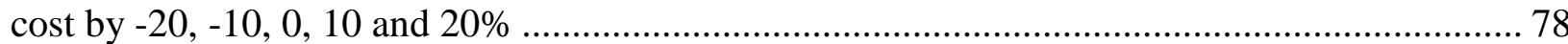
Figure 59: 30-year after-tax IRR for each scenario, testing the sensitivity of a 5.83, 6.36, 7, 7.7 and $8.4 \%$ carbon tax escalation rate. 79

Figure 60: Change in heating gross profit as a result of the carbon tax escalation rate sensitivity analysis

Figure 61: 30-year after-tax IRR for each scenario, testing the sensitivity of changing the electricity escalation rates by $-20,-10,0,10$ and $20 \%$

Figure 62: Change in heating gross profit as a result of the electricity escalation rate sensitivity analysis.

Figure 63: 30-year after-tax IRR for each scenario, testing the sensitivity of a 3333, 3636, 4000, 4400 and $4800 \mathrm{~kW}$ data centre peak cooling load

Figure 64: Optimization data centre cooling energy met by the CEN for minimized peak

provided by the CEN 100

Figure 65: Snapshot of cashflows from the Energy Sharing System financial model in Microsoft

Excel 102

Figure 66: Snapshot of cashflows from the One-Borefield System financial model in Microsoft

Excel 103

Figure 67: Snapshot of cashflows from the Two-Borefield System financial model in Microsoft

Excel 104

Figure 68: Snapshot of the 20-year hourly GLD simulation results for the One-Borefield System

Figure 69: Snapshot of GLD fluid inputs for 20-year simulation. 104

Figure 70: Snapshot of GLD soil inputs for 20-year simulation 105

Figure 71: Snapshot of GLD borehole inputs for 20-year simulation 106

Figure 72: Snapshot of GLD borefield pattern inputs for 20-year simulation. 107

Figure 73: Snapshot of TRNSYS model used to simulate the Two-Borefield System 108 109 


\begin{tabular}{|c|c|}
\hline$B V$ & Book Value (\$) \\
\hline$C F$ & Cash Flow $(\$)$ \\
\hline $\mathrm{COP}_{\text {sys }}$ & System Coefficient of Performance \\
\hline$C_{P}$ & Specific Heat Capacity (kJ/kgK) \\
\hline ES\% $\%_{\text {MURB }}$ & Energy Sharing Percentage for MURBs (\%) \\
\hline $\mathrm{ES} \% \mathrm{DC}$ & Energy Sharing Percentage for the Data Centre (\%) \\
\hline$G P M$ & Gallons Per Minute of Fluid Flow \\
\hline$H$ & Static Pressure Head (feet of water column) \\
\hline$\dot{\mathrm{m}}$ & Mass Flow Rate $(\mathrm{kg} / \mathrm{s})$ \\
\hline$\eta$ & Combined Pump Motor and Electrical Efficiency (\%) \\
\hline $\mathrm{P}_{\text {pump }}$ & Pump Power Requirement $(\mathrm{kW})$ \\
\hline Pumpeff $_{\text {eff }}$ & Pumping Efficiency Relative to \\
\hline QDC n & Data Centre's Total Cooling Load in a Given Hour (kW) \\
\hline QES & Heat Supplied from Energy Sharing (kW) \\
\hline $\mathrm{Q}_{\mathrm{L}}$ & Annual Thermal Energy Consumption (kWh) \\
\hline QMURB n & MURBs' Total Heating Load in a Given Hour (kW) \\
\hline QPeak & Peak thermal load $(\mathrm{kW})$ \\
\hline $\mathrm{T}_{\mathrm{CHWS}}$ & Chilled Water Supply Temperature to Data Centre Fan Coils \\
\hline $\mathrm{T}_{\mathrm{CHWR}}$ & Chilled Water Return Temperature from Data Centre Fan Coils \\
\hline $\mathrm{T}_{\mathrm{CW}}$ & Water Temperature from City to MURBs \\
\hline $\mathrm{T}_{\mathrm{DHW}}$ & Domestic Hot Water Temperature \\
\hline $\mathrm{T}_{\text {HWS }}$ & Hot Water Supply to MURB Fan Coils \\
\hline $\mathrm{T}_{\mathrm{HWR}}$ & Hot Water Return from MURB Fan Coils \\
\hline
\end{tabular}


$\mathrm{W}_{\text {tot }}$

$\begin{array}{ll}\text { BTES } & \text { Borehole Thermal Energy Storage } \\ \text { COP } & \text { Coefficient of Performance } \\ \text { CEN } & \text { Community Energy Network } \\ \text { CRAH } & \text { Computer Room Air Handler } \\ \text { CT } & \text { Cooling Tower } \\ \text { DHW } & \text { Domestic Hot Water } \\ \text { FC } & \text { Fan Coil } \\ \text { GHG } & \text { Greenhouse Gas } \\ \text { GLD } & \text { Ground Loop Design } \\ \text { GSHP } & \text { Ground Source Heat Pump } \\ \text { HDPE } & \text { High Density Polyethylene } \\ \text { IT } & \text { Information Technology } \\ \text { MURB } & \text { Multi-unit Residential Building } \\ \text { TRNS } & \text { TRanNient SYstem Simulation Program }\end{array}$




\section{CHAPTER I - Introduction}

\subsection{Motivation}

As the effects of climate change become increasingly apparent, there has been urgency in predicting how much change the Earth can accommodate before the effects are permanent and catastrophic. Scientists have estimated that if the Earth's average temperature increases by more than $2^{\circ} \mathrm{C}$ (compared to $1861-1880$ levels), the Earth's climate change will be permanent and hundreds of millions of lives will be at stake [1]. This allows for only $1010 \mathrm{Giga}$ tonnes of $\mathrm{CO}_{2}$ emissions (after 2012) to be emitted before the $2^{\circ} \mathrm{C}$ limit is reached [1]. This requires reducing global equivalent $\mathrm{CO}_{2}$ emissions by $49-72 \%$ between 2010 and 2050, and ultimately, will require net zero emissions by 2060-2075 [1]. Achieving these targets for the entire world will be very difficult, especially considering the projected increase in global population and the fact that many developing countries, which currently have low energy use per capita, will increase their energy use as they become more developed. District energy systems could help buildings surpass energy efficiency measures contained within the building, and thus, could be the key investment in achieving the ambitious target of a 72\% GHG emission improvement between 2010 and 2050 .

Data centres are becoming large contributors to greenhouse gas (GHG) emissions globally. In 2010, data centres accounted for between 1.1-1.5\% of global energy consumption, and 1.7$2.2 \%$ of energy consumption in the U.S. [2]. Data centre power demand is expected to increase by $15-20 \%$ annually [3]. In addition to electricity, data centres consume large volumes of water through their evaporative cooling towers. If this growth is to be sustainable, data centre operations must be reimagined as thermal energy resources, thereby offsetting their negative environmental impact and increasing their importance in society [4]. 
Data centres normally produce more heat than the offices within the building housing the data centre can consume. Typically, this excess heat is released to the atmosphere via cooling towers. District energy or community energy systems are the best way-and in most cases, the only way - to effectively use this waste heat. These systems use a network of pipes (below grade) to supply nearby buildings with heating and cooling from a variety of energy sources. Data centres can be an economically viable energy source for these systems because of their high load density and because data centres are increasingly being built close to their end users [5].

\subsection{Objectives}

The aim of the present work is to determine the optimal way to share heat between a data centre and multi-unit residential buildings (MURBs). The selected context for this work is using an existing data centre to serve as a catalyst for building out a community energy network (CEN) provided there are several surrounding mid or high rise MURBs. Three different methods are developed for sharing energy between these two building types, with the goal of finding the optimal system which maximizes the internal rate of return of the project, while also providing significant GHG reductions. All three methods are also tested for their viability in different North American cities which still require heating in MURBs. Finally, the sensitivity of key project variables are tested and the minimum data centre size for project viability is also tested.

\subsection{Outline}

Chapter 2 of this document is a literature review of data centres, residential buildings, district energy systems, equipment, ground source heat pumps and similar projects. Chapter 3 corresponds to a manuscript currently under review by the journal of Energy and Buildings, presenting a comparison of three different energy sharing systems. Chapter 4 presents a sensitivity analysis, including key project variables and various North American cities in which the project 
could be numerically tested and contrasted. Lastly, Chapter 5 presents the overall conclusions and future work for the thesis. 


\section{CHAPTER II - Literature Review}

\subsection{Data Centre Cooling}

The Information Technology (IT) electricity load of a data centre outputs an equal

amount of energy as heat [6]. There are several methods for cooling data centres, including air

cooled, water cooled and two-phase cooled. This report will focus on air cooled data centres, as

they are the most common.

\subsubsection{Air and Chilled Water Temperatures Through CRAC Units}

Air from a computer room air handling (CRAH) unit is supplied to one side of a rack of computer equipment, called the cold isle. On the other side of the rack is the "hot isle", where the heated air is returned to the CRAH units. Supply air is typically $18-27^{\circ} \mathrm{C}\left(64-81^{\circ} \mathrm{F}\right)$, according to ASHRAE TC9.9 (2011 Thermal Guidelines for Data Processing Environments) and return air temperatures are $25-40^{\circ} \mathrm{C}\left(77-104^{\circ} \mathrm{F}\right)$ [7] [8]. Figure 1 shows the recommended operating range of a data centre as well as the required operation range for data centres, as box A1 [9].

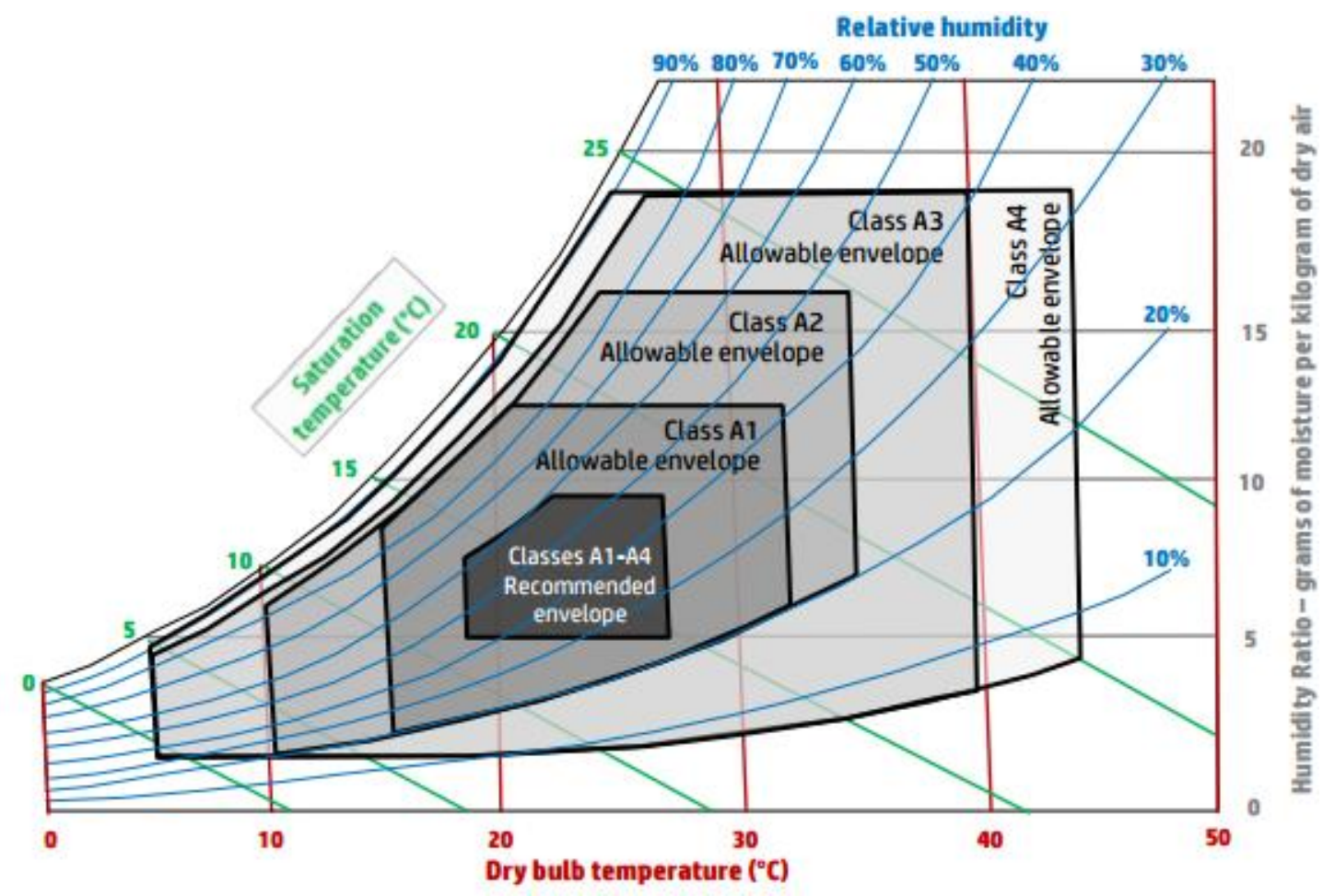

Figure 1: ASHRAE thermal guide lines for data centres [9] 
A typical legacy air cooled data centre will supply chilled water to the computer room air handling $(\mathrm{CRAH})$ unit at $7-10^{\circ} \mathrm{C}\left(45-50^{\circ} \mathrm{F}\right)$, shown in Figure 2 [10] [11]. However, a 2012 study performed by the Silicon Valley Leadership Group indicates that, more recently, the supply and return water temperatures are $10-13^{\circ} \mathrm{C}$ and $15.5-18.4^{\circ} \mathrm{C}$, respectively. The study recommends that the supply and return temperatures be raised for more efficient operation and easier waste heat recovery [12]. The coefficient of performance (COP) of a typical CRAH unit is 12 , where COP is defined in Equation 1 in which Q is the thermal energy supplied or removed from the system and $\mathrm{W}$ is the work required by the system [11].

$$
C O P=\frac{Q}{W}
$$

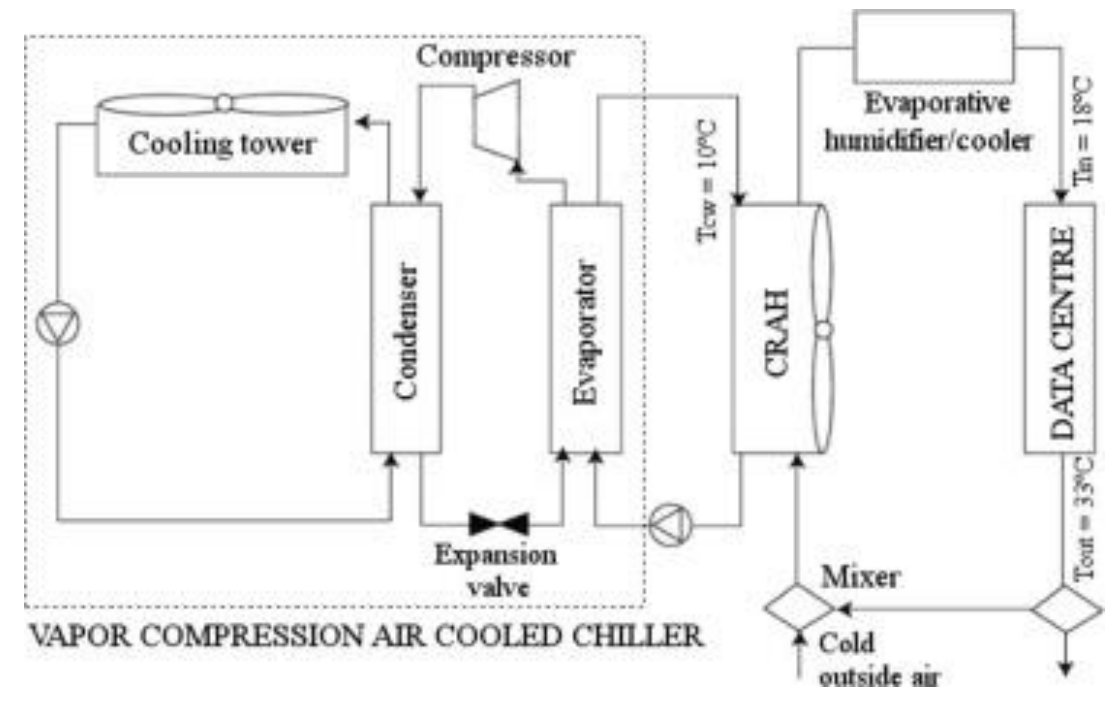

Figure 2: Data centre equipment schematic [11]

Figure 3 shows how air flows from CRAH units to cold isles, through server racks to hot isles where the air is returned [13]. 


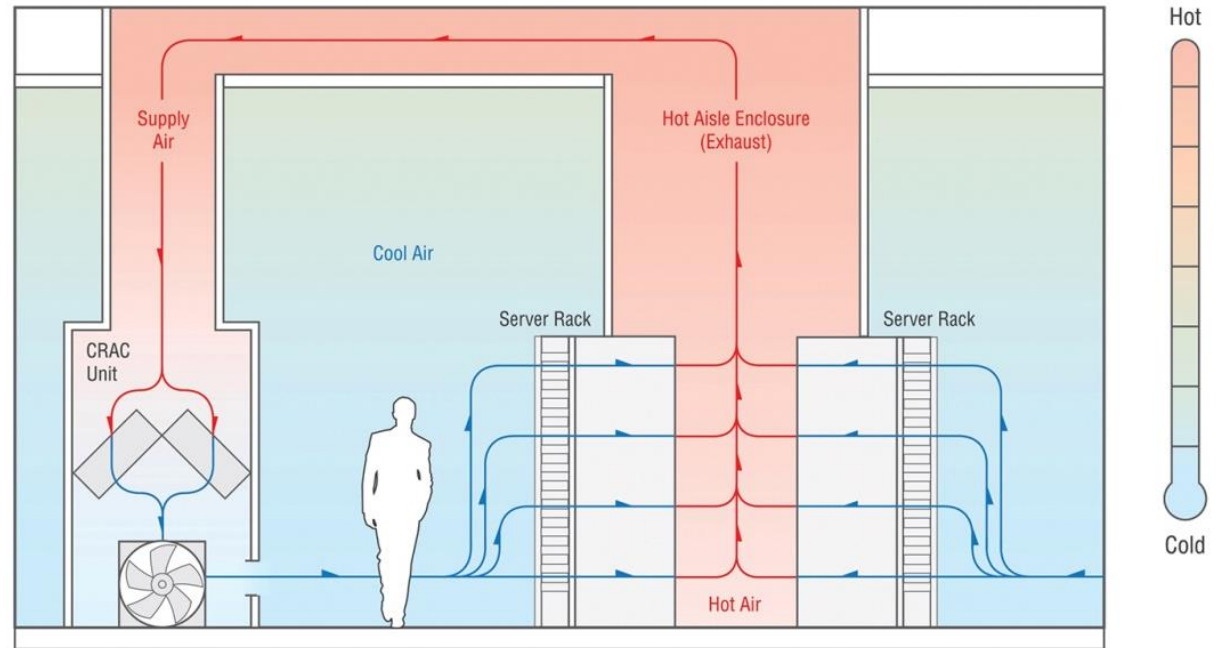

Figure 3: Air flow from CRAH unit through cold, then hot isles in a data centre [13]

\subsubsection{Chillers and Cooling Towers}

Chillers are required to produce the chilled water that is directed to CRAH units. Since data centres require outdoor air in their cooling process, the efficiency of an air cooled chiller will depend on the outdoor air temperature. Depooter et al. use the data shown in Table 1, to represent the COP of an air cooled chiller operating at $100 \%$ load, producing chilled water temperatures between 7 and $12^{\circ} \mathrm{C}$, at corresponding ambient air temperatures [11]. In order to adequately temper the outdoor air, the chiller must modulate between producing $7^{\circ} \mathrm{C}$ water during the hottest periods, and $12^{\circ} \mathrm{C}$ water during the coldest periods.

Table 1: COP of an air cooled chiller for cooresponding outdoor air temperatures (adopted from [11])

\begin{tabular}{|l|c|c|c|c|c|c|c|c|c|}
\hline Temperature $\left({ }^{\circ} \mathrm{C}\right)$ & 0 & 5 & 10 & 15 & 20 & 25 & 30 & 35 & 41 \\
\hline COP & 5.82 & 5.49 & 5.13 & 4.74 & 4.34 & 3.93 & 3.52 & 3.12 & 2.66 \\
\hline
\end{tabular}

Cooling towers intake water from a chiller's warm condenser side and reduce the water temperature by approximately $10^{\circ} \mathrm{F}$, via evaporative cooling [14]. A water-cooled chiller's operating efficiency is inversely proportional to its condenser water supply temperature; efficiency 
increases as condenser water supply temperature decreases. Figure 4 shows COP at condenser water supply temperatures between $85^{\circ} \mathrm{F}$ and $55^{\circ} \mathrm{F}[15]$.

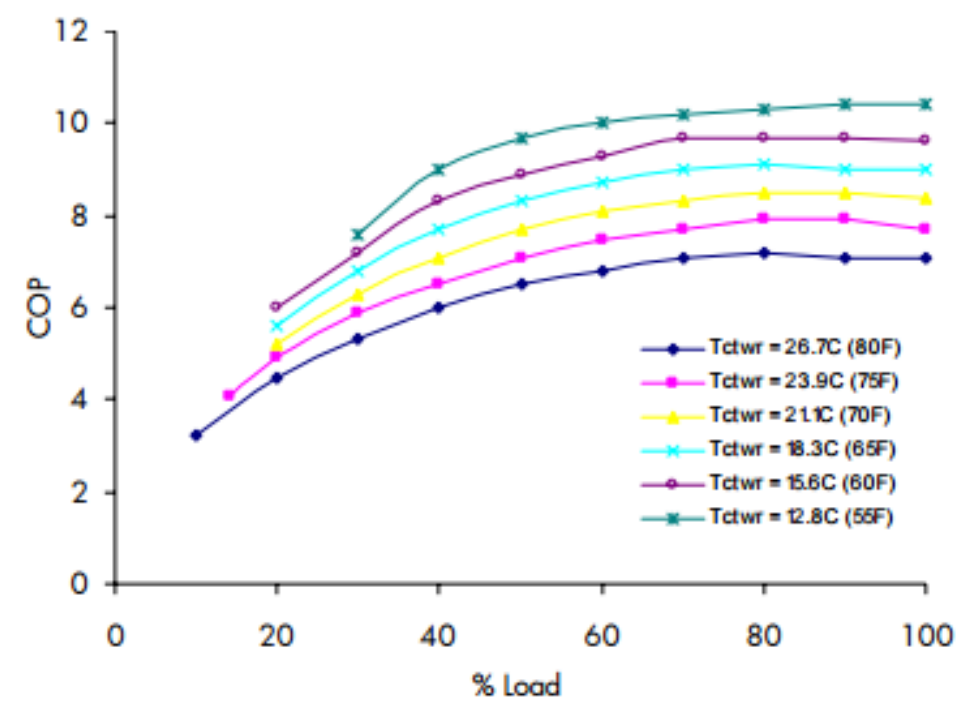

\section{Figure 4: Trane performance data at various condenser water entering temperatures for constant speed chillers [15]}

\subsubsection{Cooling Load Profiles and Free Cooling}

Data centres require cooling 8760 hours per year, due to the large amount of process heat generated from the server racks that provide internet, uphold cloud services and provide external processing power for jobs such as animations at any hour of the day. Twenty Two data centres were surveyed by the American Council for an Energy Efficient Economy (ACEEE). The council found that, on average, HVAC equipment used to cool IT equipment required $60 \%$ as much energy as the IT equipment consumes itself [16]. Considering the fact that data centres can be over 40 times more energy intensive than office buildings, there is a large requirement for cooling as a result of the large electrical load of servers [16].

Daikin, an air conditioning manufacturing company, performed a simulation for cooling a data centre in Minneapolis. The simulation considered a 300-ton air cooled screw chiller with integrated free cooling [17]. Figure 5 shows the results of the simulation, where the y-axis 
represents the chiller electricity consumption and the $\mathrm{x}$-axis represents hourly time steps throughout one year. Even with the cold air of the winter assisting in the cooling, the cooling load profile is relatively constant throughout the year [17].

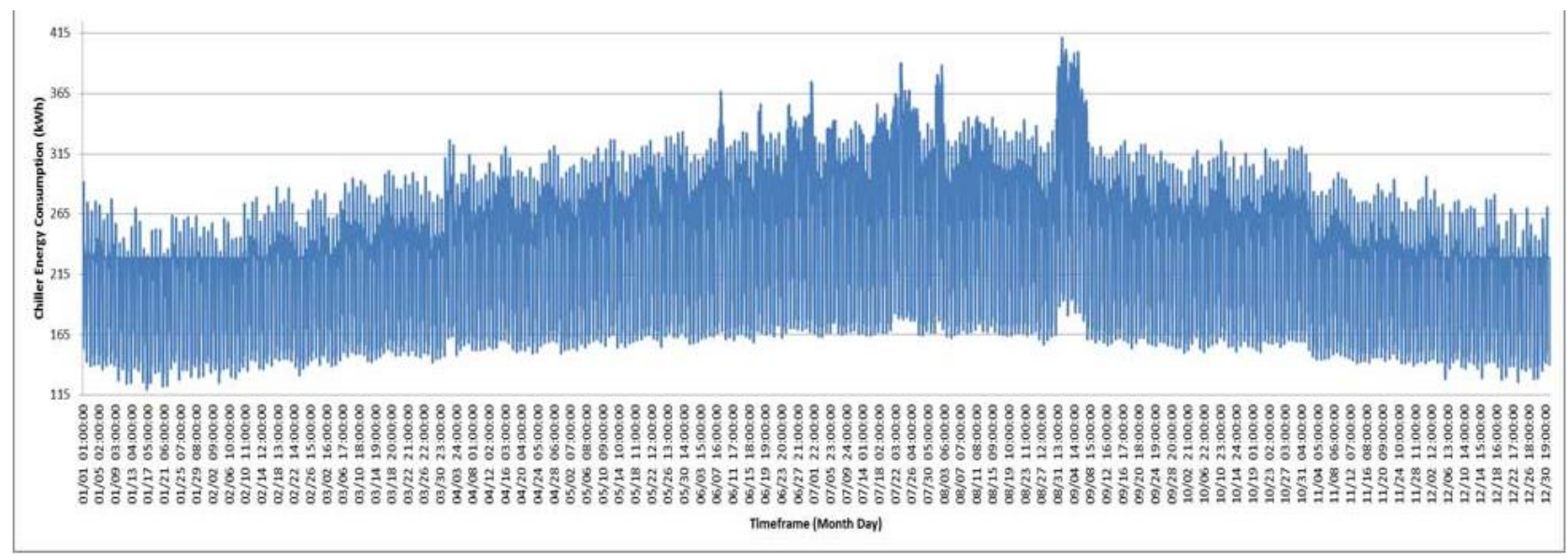

Figure 5: Daikin simulation of 300-ton air-cooled screw chiller with integrated free cooling, showing hourly energy consumption in a data centre over a year [17]

\subsection{Residential High-Rise}

\subsubsection{Heating and Cooling System}

The typical mid- or high-rise residential building in Toronto uses a fan coil based heating system. ASHRAE 90.12007 Appendix G defines that hot water supply to fan coils in buildings can be between $82^{\circ} \mathrm{C}\left(180^{\circ} \mathrm{F}\right)$ and $66^{\circ} \mathrm{C}\left(150^{\circ} \mathrm{F}\right)$, when the outdoor air temperature is between $-7^{\circ} \mathrm{C}$ $\left(19^{\circ} \mathrm{F}\right)$ and $10^{\circ} \mathrm{C}\left(50^{\circ} \mathrm{F}\right)$, respectively [18]. Typical buildings use fan coils that are designed to require $130-150^{\circ} \mathrm{F}$ supply and $120-140^{\circ} \mathrm{F}$ return on the coldest days of the year, to provide adequate heating [19] [20]. Natural gas boilers are used to produce these temperatures. Noncondensing boilers have a manufacturer's efficiency of approximately 70-78\% [21]. Condensing boilers are used to produce supply temperatures below $140^{\circ} \mathrm{F}$ [20]. Condensing boilers can produce higher efficiencies between $80-90 \%$ because condensation of the exhaust stream is possible at 
lower temperatures [21]. The condensed flue gas is used to preheat water entering the boiler, which saves energy.

ASHRAE states that chilled water supply temperature to fan coils can be $7^{\circ} \mathrm{C}\left(45^{\circ} \mathrm{F}\right)$ to $12^{\circ} \mathrm{C}\left(54^{\circ} \mathrm{F}\right)$, between outdoor temperatures of $27^{\circ} \mathrm{C}\left(80^{\circ} \mathrm{F}\right)$ to $16^{\circ} \mathrm{C}\left(60^{\circ} \mathrm{F}\right)$ [18]. Chillers are commonly used in this type of building to produce these temperatures. The COP of the average chiller is 5.0 [22]. Evaporative cooling towers are required to lower the temperature that exits the condenser side of the chiller at approximately $95^{\circ} \mathrm{F}$ and reduce it to $85^{\circ} \mathrm{F}$ [14]. The efficiency of a typical cooling tower is $0.3 \mathrm{~kW} /$ ton due to the operation of fans, making the typical combined chiller and cooling tower COP 3.5 [23]. Fan coil buildings can have either two or four riser pipes for space heating and cooling. Four pipe designs allow heating and cooling to occur at the same time to meet different occupant requirements in the building. Two pipe designs cannot provide the increased occupant comfort but require less capital cost and generally conserve energy.

\subsubsection{Domestic Hot Water}

Domestic hot water (DHW) needs to be stored in buildings at a minimum temperature of $122^{\circ} \mathrm{F}\left(50^{\circ} \mathrm{C}\right)$ to prevent the growth of Legionella, a pathogen that can cause disease if inhaled through steam in a shower [24]. At $140^{\circ} \mathrm{F}\left(60^{\circ} \mathrm{C}\right)$ any legionella will die in approximately 30 minutes [24]. Some buildings only heat their domestic hot water to $140^{\circ} \mathrm{F}$ once a day, week or month, depending on the local regulation. They are allowed to do this because legionella will only grow in stagnant water. In a residential building a large amount domestic hot water is used every day for showers and dishwashers. This provides a steady flow and the domestic hot water tanks only need to be overheated to $140^{\circ} \mathrm{F}$ as a safety measure to purge the legionella. The Ontario building code requires domestic water be heated to $140^{\circ} \mathrm{F}\left(60^{\circ} \mathrm{C}\right)$ to ensure that Legionella never grows [25]. 
Domestic hot water boilers can be condensing, due to the low entering water temperature and therefore operate with $80-90 \%$ efficiency [21]. The typical domestic hot water configuration in a mid- or high-rise residential building goes through the following process. Cold city water enters the building, where it is pumped up a single riser pipe to the mechanical penthouse where a portion of the water is supplied to the domestic hot water boiler and the rest is allocated for domestic cold water. After the water is heated to at least $140^{\circ} \mathrm{F}$ it is sent to storage tanks. When domestic hot water is demanded, the water is supplied down to suites where it is consumed and subsequently, sent down the drain to a waste water treatment plant. To maintain a maximum temperature of $49^{\circ} \mathrm{C}\left(120^{\circ} \mathrm{F}\right)$, within the DHW supply pipes, water must be constantly circulated and reheated [26]. The recirculation pipe is shown in Figure 6, where F.U. is fan coil unit count.

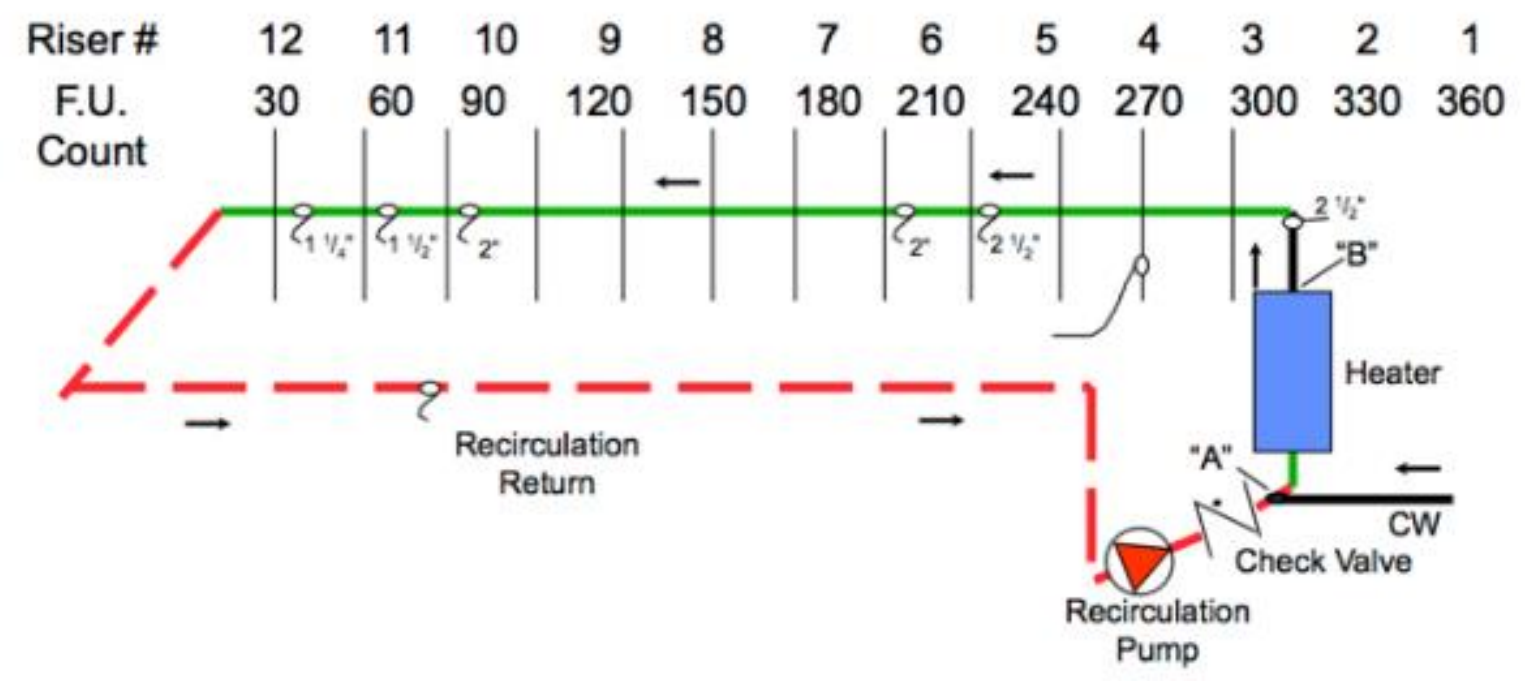

Figure 6: Recirculation pipe line diagram, showing supply and return from building risers with DHW heater, pump and city water supply [27]

\subsubsection{Make-Up Air Units}

Makeup air units are used to pressurize the hallways of a building, in order to prevent heat or cooling from leaking out of the suites. The makeup air must be heated in the winter and is typically cooled in the summer. This is typically done with one natural gas fired packaged unit for 
heating, and a separate electric unit for makeup air cooling. The makeup air is supplied down through ducts to each floor's hallway. Makeup air units can be retrofitted to have hydronic coils, enabling them to be connected to hot water-based district energy systems.

\subsubsection{Energy Use Intensities}

The Toronto Atmospheric Fund conducted a study using 40 real MURBs in Toronto. The study found that the total energy intensity of a MURB in Toronto is $292 \mathrm{ekWh} / \mathrm{m}^{2}$ [28]. This value was calculated by normalizing weather over the last 30 years using CWEC data [28]. The study also found that $66 \%$ of a building's energy consumption is natural gas and $34 \%$ is electricity [28].

Another study performed by Ghajarkhosravi analyzed data on 106 MURBs in the Greater Toronto area and found a slightly higher total median energy use intensity (EUI) of $337 \mathrm{ekWh} / \mathrm{m}^{2}$ [29]. The study also broke out natural gas consumption EUIs for space heating and electricity consumption EUIs for space cooling and found that the medians were $181 \mathrm{ekWh} / \mathrm{m}^{2}$ and 4 $\mathrm{ekWh} / \mathrm{m}^{2}$ [29]. The low cooling EUI can be explained by the fact that some of these buildings have minimal cooling.

The peak loads of several residential buildings have been aggregated by Enwave Energy Corporation, to find the averages shown in Table 2 [30]. These peak load intensities reflect the actual building peak, not the installed capacity.

Table 2: Average peak intensities of residential buildings connected to Enwave's district energy system, aggregated by Carson Gemmill [30]

\begin{tabular}{|l|c|}
\hline \multicolumn{1}{|c|}{ Peak Loads } & Peak Intensities \\
\hline Space Heating & $39 \mathrm{~W} / \mathrm{m}^{2}$ \\
\hline Space Cooling & $38 \mathrm{~W} / \mathrm{m}^{2}$ \\
\hline Domestic Hot Water & $32 \mathrm{~W} / \mathrm{m}^{2}$ \\
\hline
\end{tabular}

\subsubsection{High-rise MURB Load Profile}

The following data is from an energy model of a high-rise condominium located in downtown Toronto. Figure 7 and Figure 8 show the percentage of peak heating and cooling for 
every hour of the year. This heating load profile was used in Chapter 3 to represent a typical existing MURB which could connect to a community energy network. Figure 7 shows a consistent DHW profile, with winter and shoulder season space heating loads. The peak intensity for this load profile is $89 \mathrm{~W} / \mathrm{m}^{2}$ which is slightly high compared to the sum of DHW and space heating peak intensities collected in Table 2 of $71 \mathrm{~W} / \mathrm{m}^{2}$ [30]. The space heating energy intensity was 130 $\mathrm{kWh} / \mathrm{m}^{2}$, slightly lower than the median space heating energy intensity of $145 \mathrm{kWh} / \mathrm{m}^{2}$ found in the study by Ghajarkhosravi, assuming an $80 \%$ boiler efficiency [29]. The total heating energy intensity (including DHW) was $161 \mathrm{kWh} / \mathrm{m}^{2}$, on par with the average total heating energy intensity of $154 \mathrm{kWh} / \mathrm{m}^{2}$ found in the Toronto Atmospheric Fund study, assuming an $80 \%$ boiler efficiency [28].

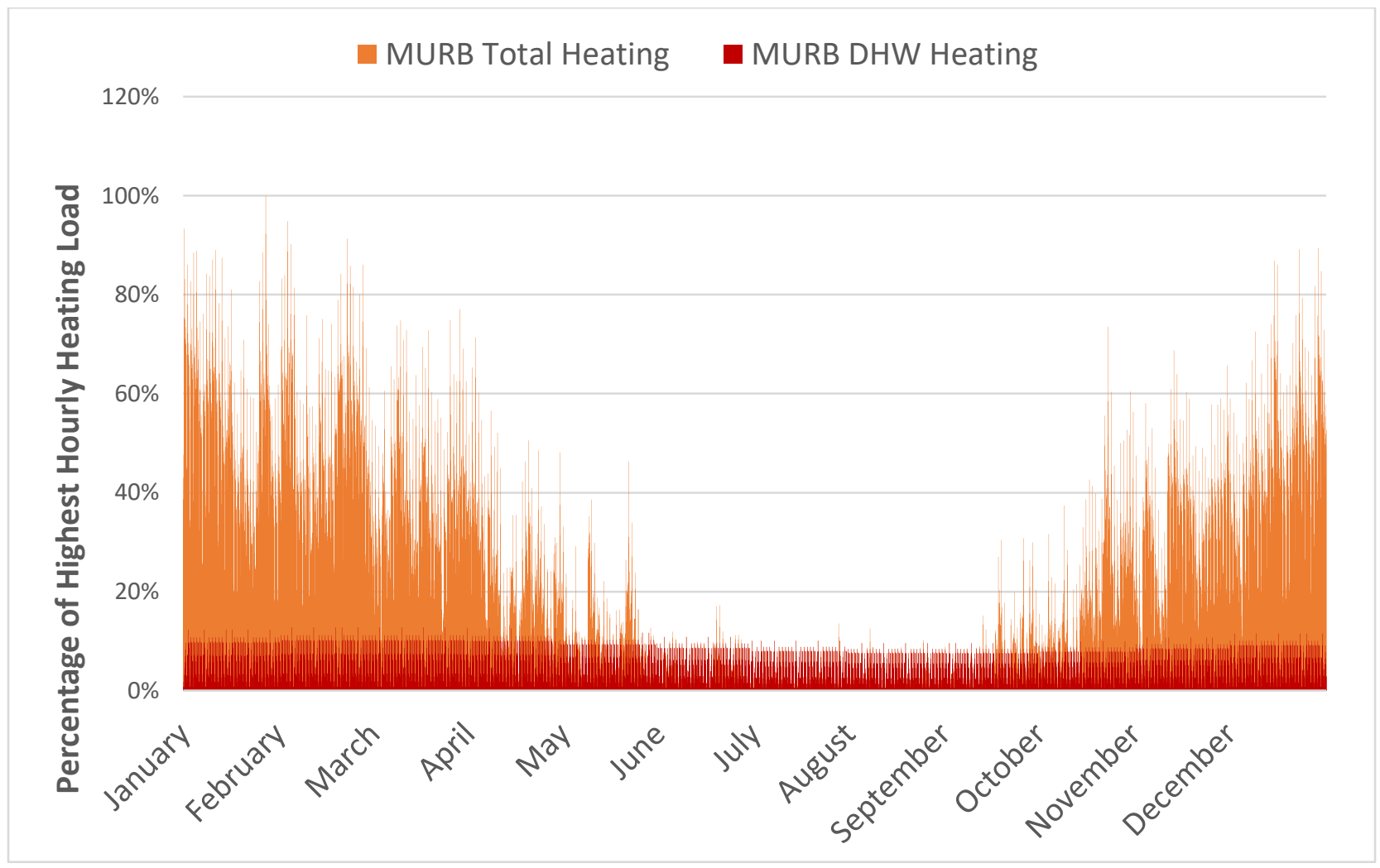

Figure 7: Average hourly MURB heating load profile from a building energy model provided by Enwave, showing the percentage of the buildings peak heating which is attributed to domestic hot water (DHW) and the combined space heating and DHW heating load as a percentage of the peak hourly heating load [30] 


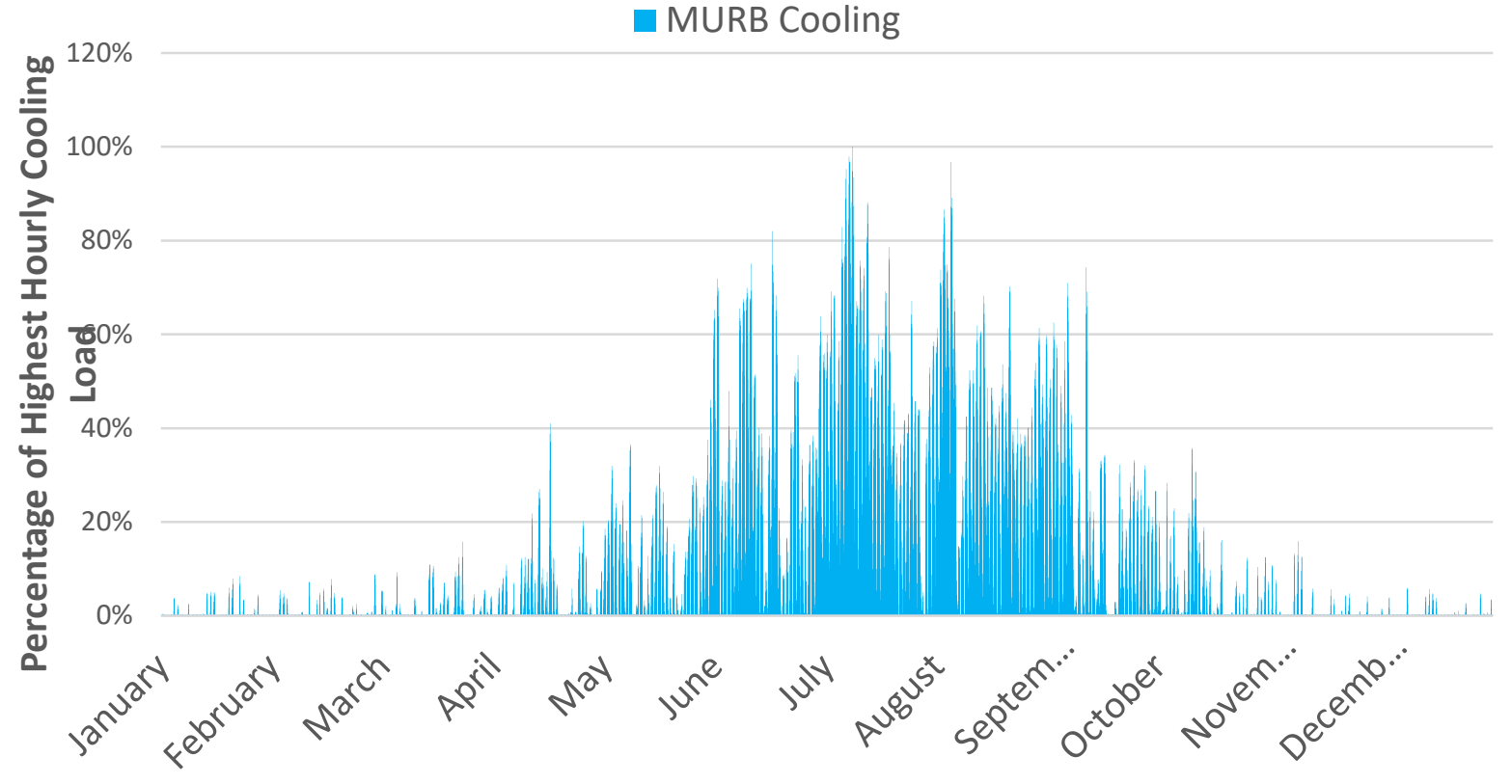

Figure 8: Average hourly MURB cooling load profile from a building energy model provided by Enwave, showing the percentage of the buildings peak cooling load at all hours of the year [30]

Figure 9 is a load duration curve, using the same data as Figure 7 and Figure 8 to show the number of hours, in which the building operates certain percentage of peak. This data indicates that residential buildings rarely reach their peak and the majority of their energy is consumed at lower proportions of peak.

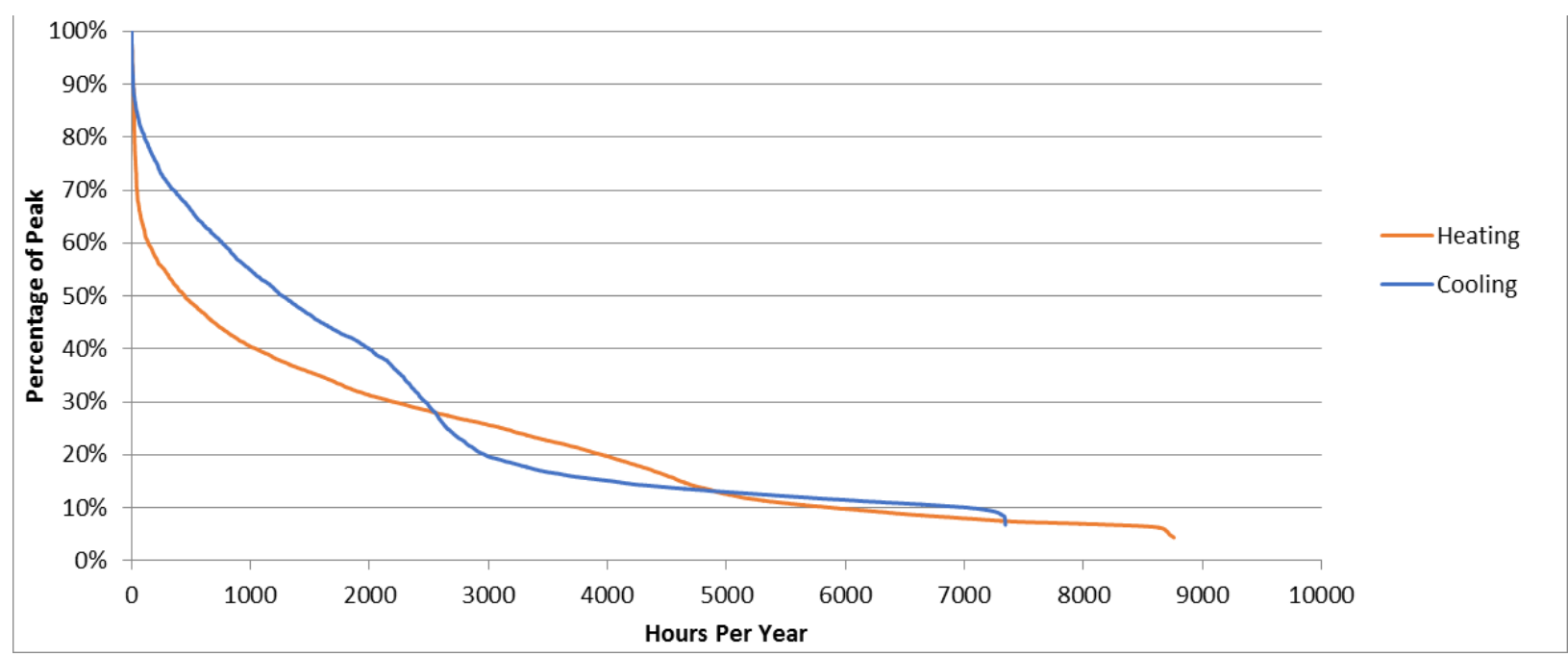

Figure 9: Heating and cooling load duration curve of one of Enwave's metered residential buildings [30] 


\subsection{District Energy}

District energy is the process of piping thermal energy from external sources to multiple buildings for use in heating and cooling. It is an alternative to placing boilers and chillers in the penthouse of each building. District energy has four main advantages that will be described below.

The first advantage of this system is the economies of scale; district energy central plants can have much larger pieces of mechanical equipment than would be seen in a building. They also have the benefit of needing only one or two operators, whereas a standalone building may have its own dedicated operator or at least a hired person to constantly check on the equipment.

Second, reliability is a key advantage of a district energy system. Standalone buildings have difficulty financially justifying the purchase of extra equipment as back up, since only one machine is typically required for each process (one boiler and one chiller). In a district energy central plant, the loads are so large that they have to be split into smaller pieces of mechanical equipment. This makes it easy to justify purchasing extra boilers or chillers to run as back up in the case of machine failures or scheduled maintenance.

Third, district energy is ideal for multiple energy sources, making it by far the most effective way of integrating renewables. Renewable energy, such as solar, wind, and sewer heat recovery, are intermittent, but when combined can produce a relatively constant load. If these systems are also combined with other more reliable energy sources, such as ground or lake-source heat pumps, biogas, biomass, boilers and chillers, then new technologies will be given the chance to thrive on a large scale in the commercial market.

Fourth, district energy takes advantage of load diversity. Load diversity is the difference between the sum of each individual building's peak occurring at different times of the year compared to the highest sum of instantaneous building loads. If office buildings and residential buildings are on the same district energy system, they will peak at nearly opposite times. This 
means that a central plant can be sized to accommodate the peak load at the highest aggregate demand, which can be around $30 \%$ less than the sum of the peak load of each building [31]. Load diversity was not taken into account in the analysis in Chapter 3.

\subsubsection{Hot Water Systems}

Hot water district energy systems provide the opportunity to aggregate the largest variety of energy sources because water can be distributed at any temperature between $0^{\circ} \mathrm{C}$ and $100^{\circ} \mathrm{C}$. Many legacy district energy systems that distributed heat through steam are converting to hot water, in order to take advantage of waste heat sources, solar thermal collectors, and medium temperature geothermal energy. Hot water is very effective for thermal storage, allowing for the use of intermittent energy sources. It also has less distribution losses and reduced maintenance costs compared to steam systems [32]. Hot water systems have lower exergy than steam systems. Hot water district energy systems distribute water at a temperature that is as close to in building space heating water temperatures requirements as possible. Figure 10 shows how Sweden's district energy systems have produced far less emissions, since transitioning to hot water systems, starting in the 1980s. Energy sources such as waste heat could only be distributed through a hot water system because of their low temperature.

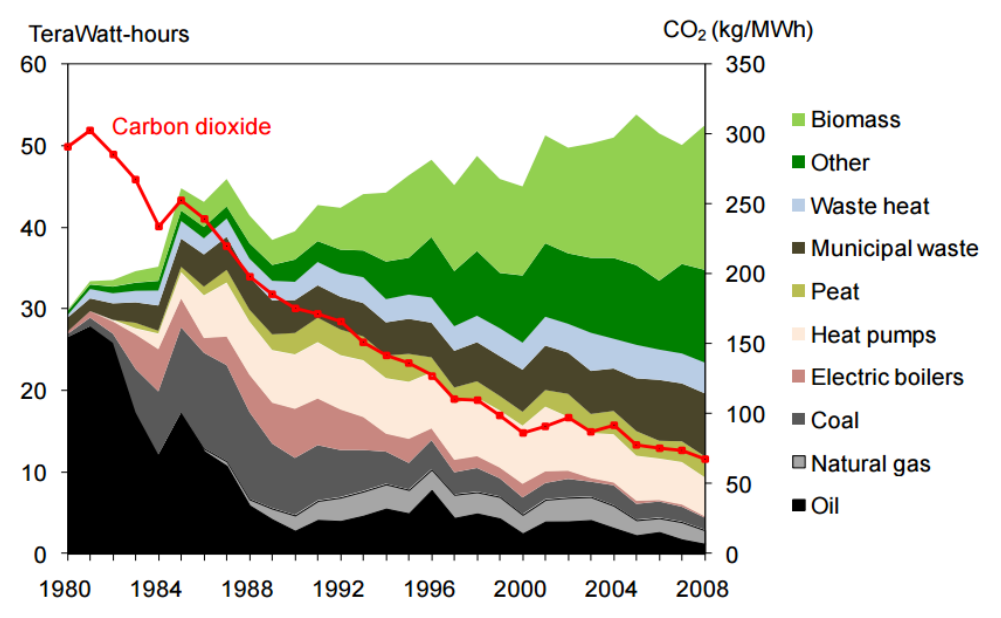

Figure 10: Energy use and $\mathrm{CO}_{2}$ emissions data from Sweden's district energy systems, from 1980 to 2008 [32] 


\subsubsection{Energy Sharing}

Energy sharing between buildings can be done when one building has a heating load that coincides with another building's cooling load. Figure 11 shows the waste heat temperature of a variety of energy sources, prepared by FVB Energy [32]. The higher the temperature of the energy source, the more valuable it is. This thesis will focus on the lowest temperature energy source, chiller condenser heat, shown in Figure 11.

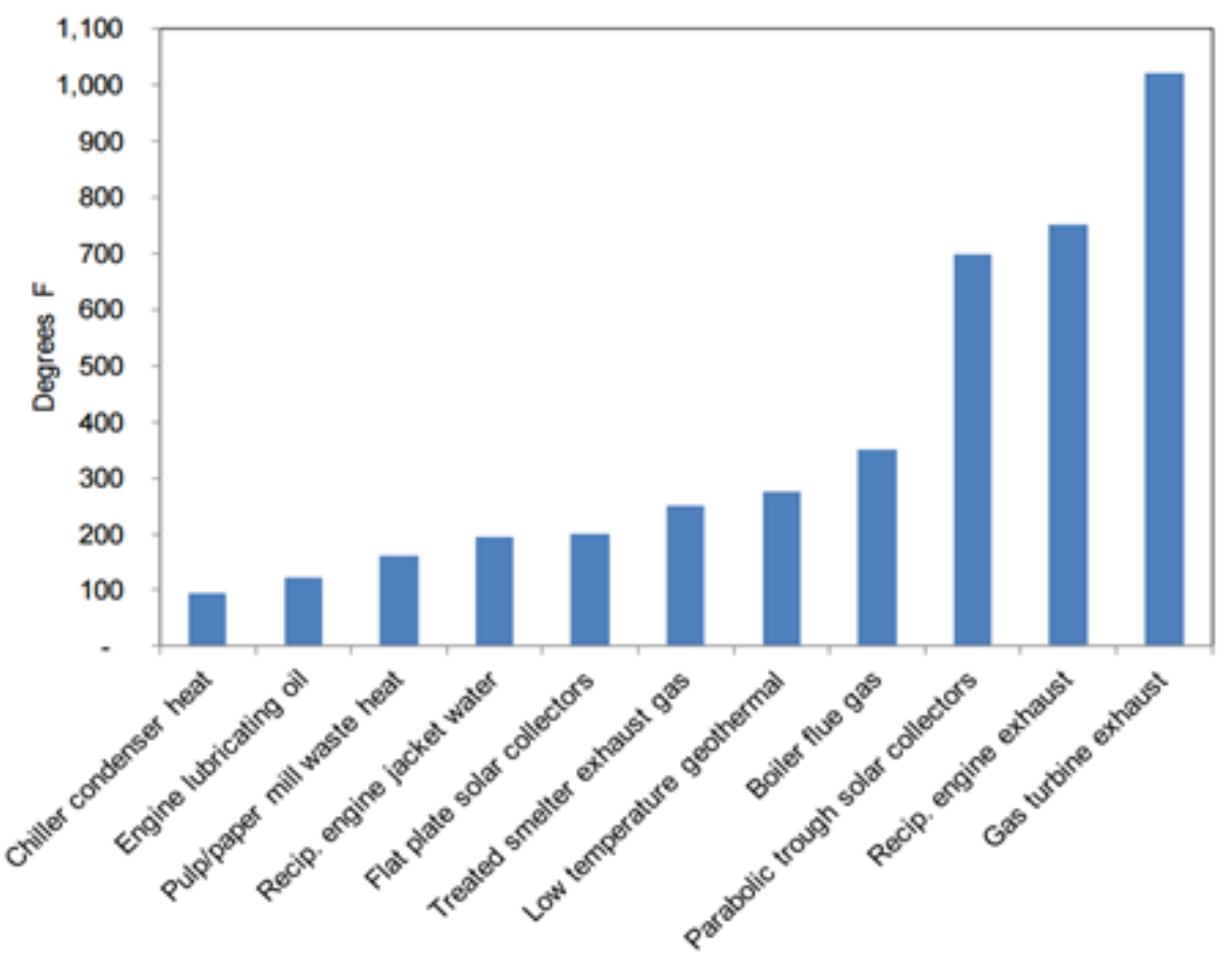

Figure 11: Waste heat temperature of various energy sources that are commonly used in district energy, prepared by FVB Energy [32]

Thermenex is a company founded on effectively utilizing waste heat. The company holds a patent on a system called a Thermal Gradient Header. Essentially, this involves a long serpentine pipe, which contains different temperatures throughout, as shown in Figure 12, contained within the mechanical room of a building [33]. This system allows waste heat to be recovered from all building processes, such as chiller condenser heat and exhaust heat. It can even make use of temperatures below $0^{\circ} \mathrm{C}$ because they are still warmer than outdoor air at certain times of the year 
[34]. The main purpose of this system within a building is to provide heating and cooling simultaneously with a chiller, only using boilers to deliver higher supply temperatures in extreme cold weather.

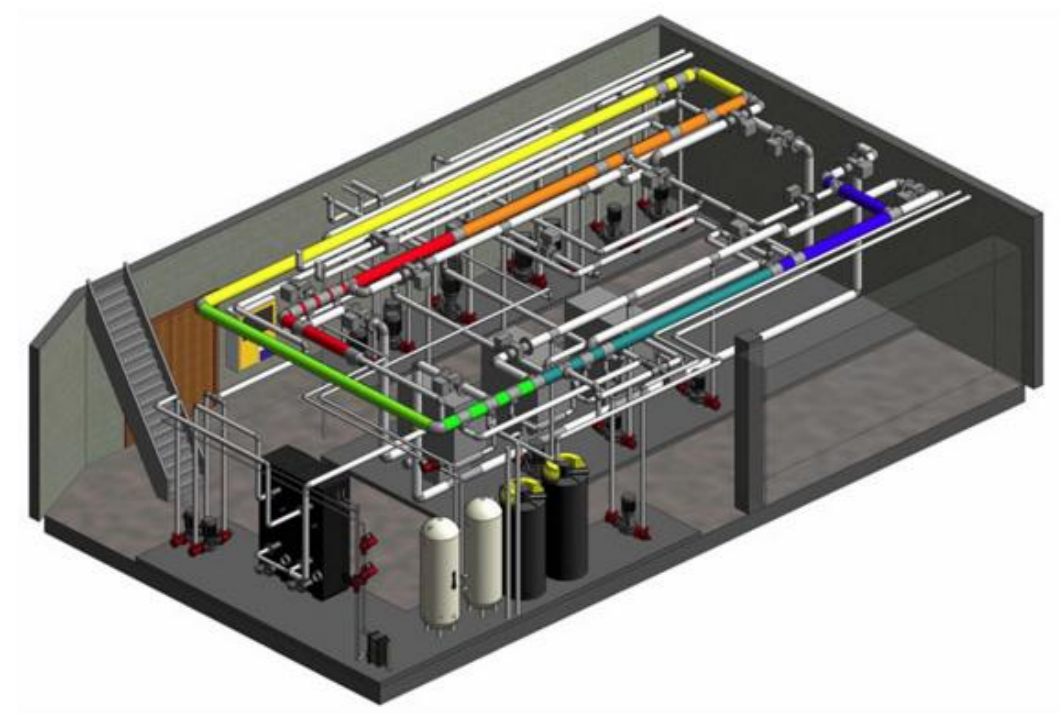

Figure 12: Thermenex Thermal Gradient Header, contained within building mechanical room [33]

Thermenex has also applied its technology on a district scale. Thermemex treats large buildings as thermal energy resources. The company has designed and implemented a community energy system, which connected a pool, an ice rink and a city hall building [35]. Since the pool and the ice rink have year-round heating and cooling loads, respectively, it is logical to share energy. Indeed, Thermenex succeeded in implementing the system and achieving their modelled results. Figure 13 shows that the community centre greatly reduced its boiler's natural gas consumption during the summer [35]. Figure 14 shows that overall energy use in the summer is also reduced; however, not as much as the natural gas consumption specifically [35]. This project achieved a large reduction in GHG emissions, as fuel switched from natural gas to a relatively clean source of electricity and ultimately, energy consumption was reduced. 


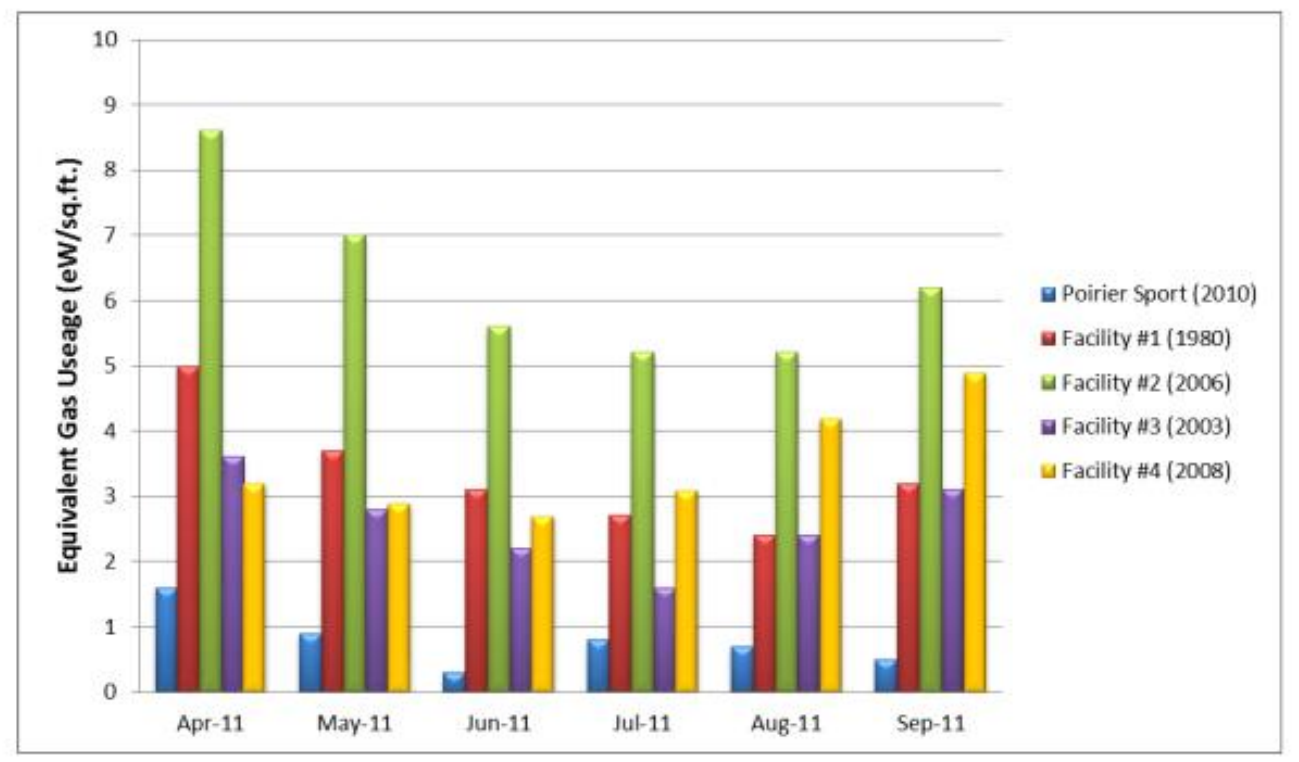

Figure 13: Themenex aquatic centre project, showing resulting natural gas intensity of Thermenex aquatic centre, compared to similar facilities during summer months [35]

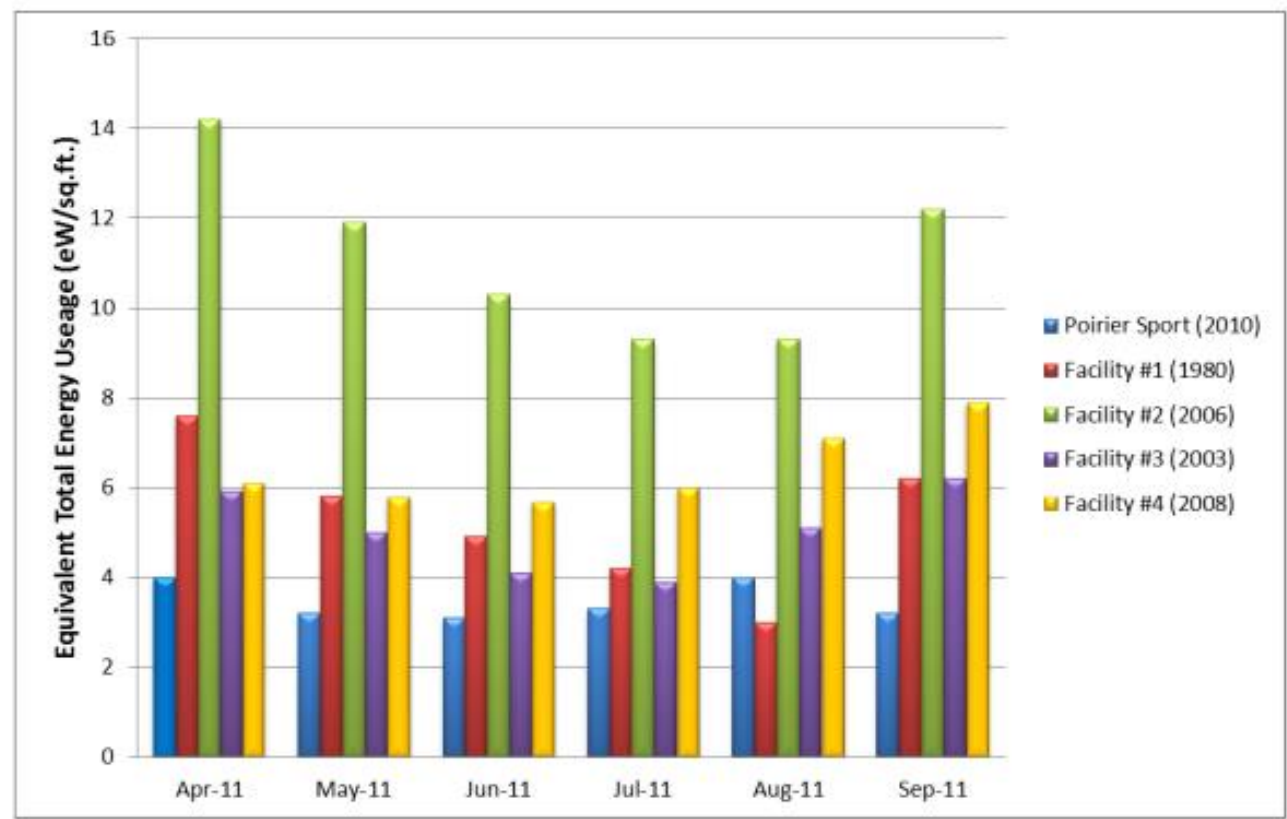

Figure 14: Themenex aquatic centre project, showing resulting total energy intensity of Thermenex aquatic centre, compared to similar facilities during summer months [35]

Thermenex uses multiple distribution or connection temperatures in their district systems through their serpentine pipe, shown in Figure 15. This is designed to minimize the energy losses associated with mixing temperatures and reducing the value of the thermal energy. 


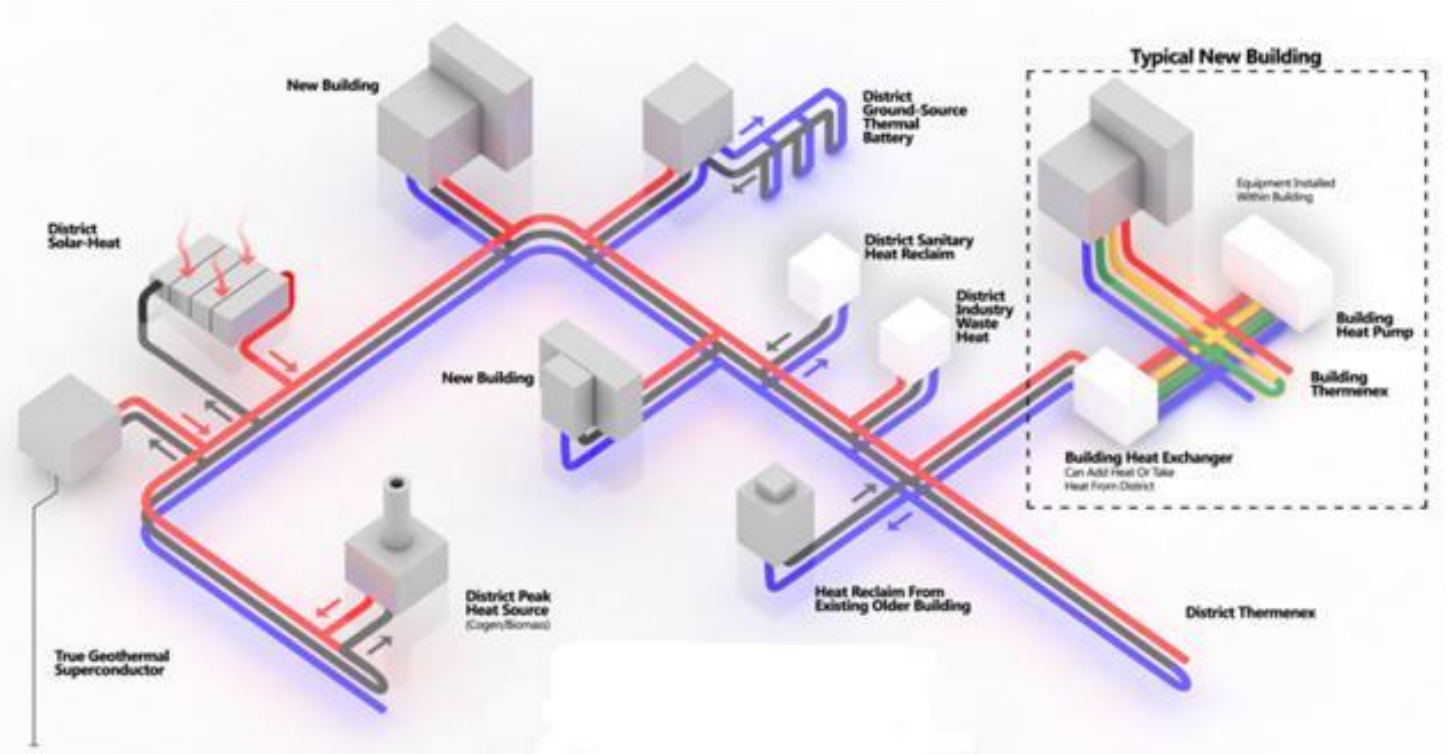

Figure 15: Example of Thermenex district energy network, incorporating the serpentine, multi-temperature pipe [33]

\subsection{Water to Water Heat Pumps}

Water to water heat pumps move heat in the opposite direction of normal flow. An expansion device reduces the pressure of liquid refrigerant, changing it to liquid-vapour form [36]. The low pressure refrigerant then goes through an evaporator, in which it absorbs heat from the colder entering water and boils into low temperature vapour [36]. The vapour then goes to an electric driven compressor, which reduces its volume causing the refrigerant to heat up [36]. The hot refrigerant vapour is then directed to a condenser, where the warmer entering water is heated through coils [36]. The refrigerant is subsequently returned to cooler liquid form, where it repeats the cycle. The heat pump can produce high or low temperatures, by choosing whether the load side of the heat pump is the condenser or the evaporator, respectively. Figure 16 shows that as the required output temperature rises and the evaporator supply temperature remains constant, the efficiency of the heat pump falls, roughly linearly. 


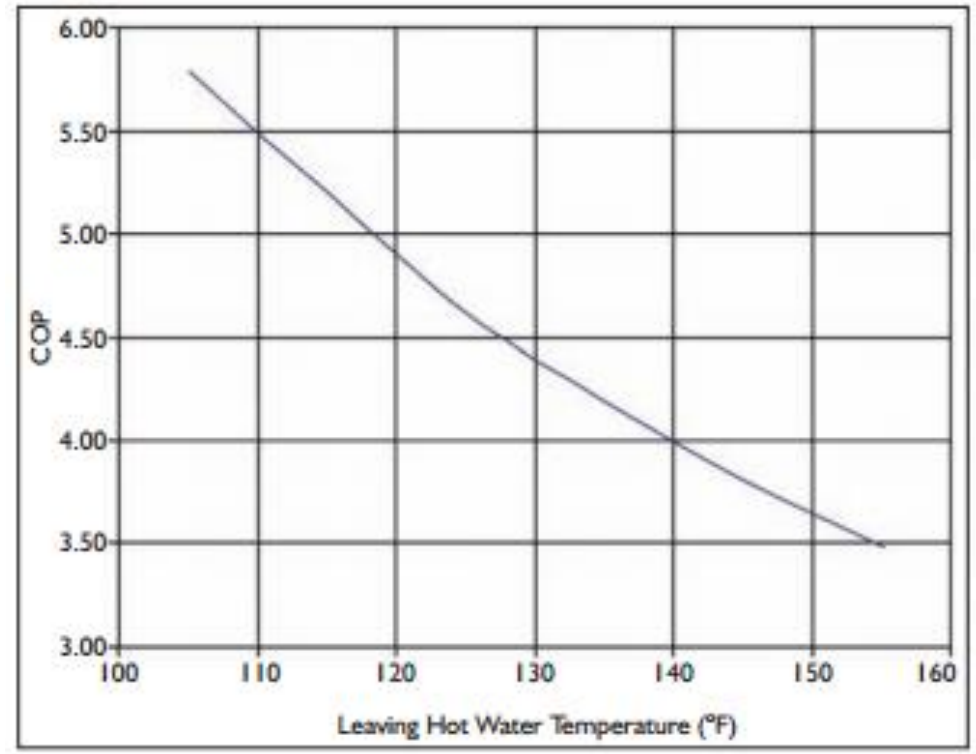

Figure 16: Heat pump COP versus hot-water supply temperature, with $42^{\circ} \mathrm{F}\left(6^{\circ} \mathrm{C}\right)$ chilled water supply temperature from ASHRAE [37]

Heat recovery chillers are the same as heat pumps, except they can be used for both heating and cooling at the same time. Heat recovery chillers can simultaneously produce $7^{\circ} \mathrm{C}\left(44^{\circ} \mathrm{F}\right)$ on the evaporator side and $54^{\circ} \mathrm{C}\left(130^{\circ} \mathrm{F}\right)$ on the condenser side, making them a perfect fit for residential building fan coil systems [38].

\subsection{Dry Coolers}

Dry coolers act as a heat exchanger between the outdoor air and the water/fluid, used for cooling. Fans draw air over a fin tube heat exchanger, which cools down the water contained in the tubes. Since dry coolers only require electricity to power fans, they are very efficient. However, their efficiency depends on the outdoor air temperature. A dry cooler can start being effective once the outdoor air temperature is $5^{\circ} \mathrm{C}$ less than the required supply air temperature or 1.5 to $2^{\circ} \mathrm{C}$ below the required chilled water supply temperature [39]. Glycol must be mixed into the water to avoid freezing in the dry cooler tubes. Freezing can lead to excessive repairs or even complete replacement. In the Toronto climate a $35 \%$ glycol mixture may be required to prevent the fluid 
from freezing at temperatures as low as $-20^{\circ} \mathrm{C}$ [39]. Figure 17 shows the fin tube heat exchanger that the fluid passes through and the fan used to draw air through it.

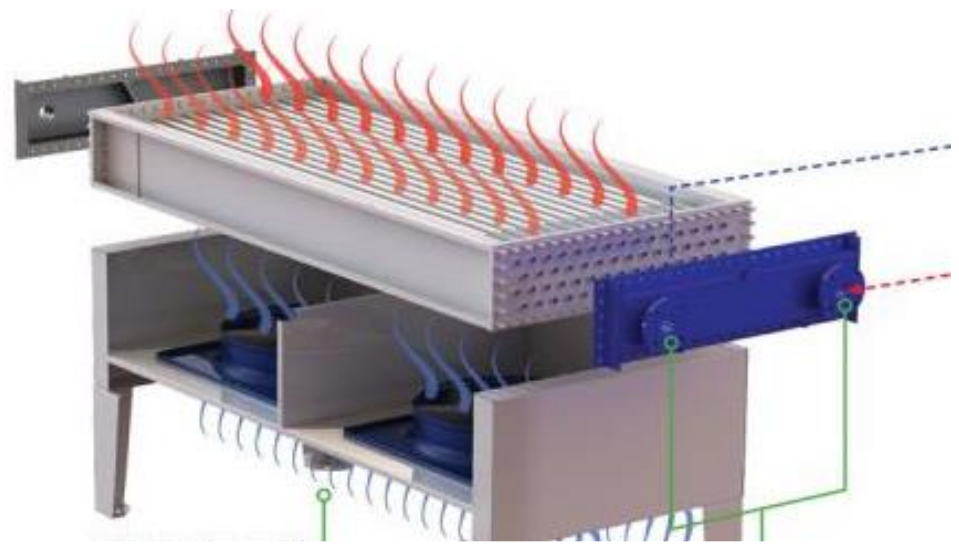

Figure 17: Dry cooler, showing fin and tube heat exchanger and fan used to draw air through it [40]

Daikin performed a simulation on a data centre comparing a regular chiller without free cooling, an integrated chiller with free cooling, and a chiller with a separate dry cooler. Figure 18 shows that free cooling with a dry cooler was the best way to reduce overall energy consumption in cold climates [17]. Chillers using integrated free cooling have reduced efficiency during the summer because they are subject to the open air, while dry coolers can be shut off during the summer.

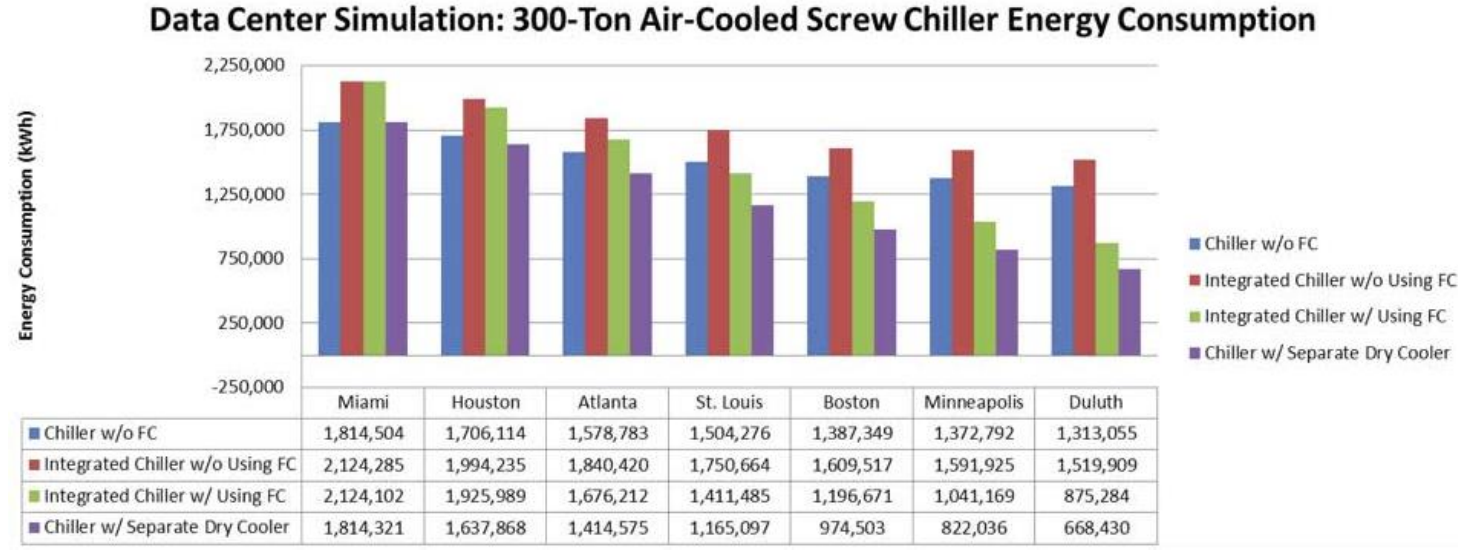

Figure 18: Daikin simulation of 300 ton air-cooled screw chiller, showing energy consumption in a data centre over a year, with various equipment configurations [17] 


\subsection{Ground Source Heat Pumps}

Ground source heat pump systems have been used since 1980 to provide heating and cooling to buildings [41]. The temperature of the ground in Toronto is $10^{\circ} \mathrm{C}$ year-round, at a depth of approximately $10 \mathrm{~m}$ and deeper, as shown in Figure 19 [42] [43]. Since this temperature is constant, it is always warmer than the air during the winter and colder in the summer. This makes the energy in the ground a valuable source and sink for ground source heat pumps. It also allows a ground source heat pump to operate at a higher efficiency than air source heat pumps, especially in extreme weather conditions.

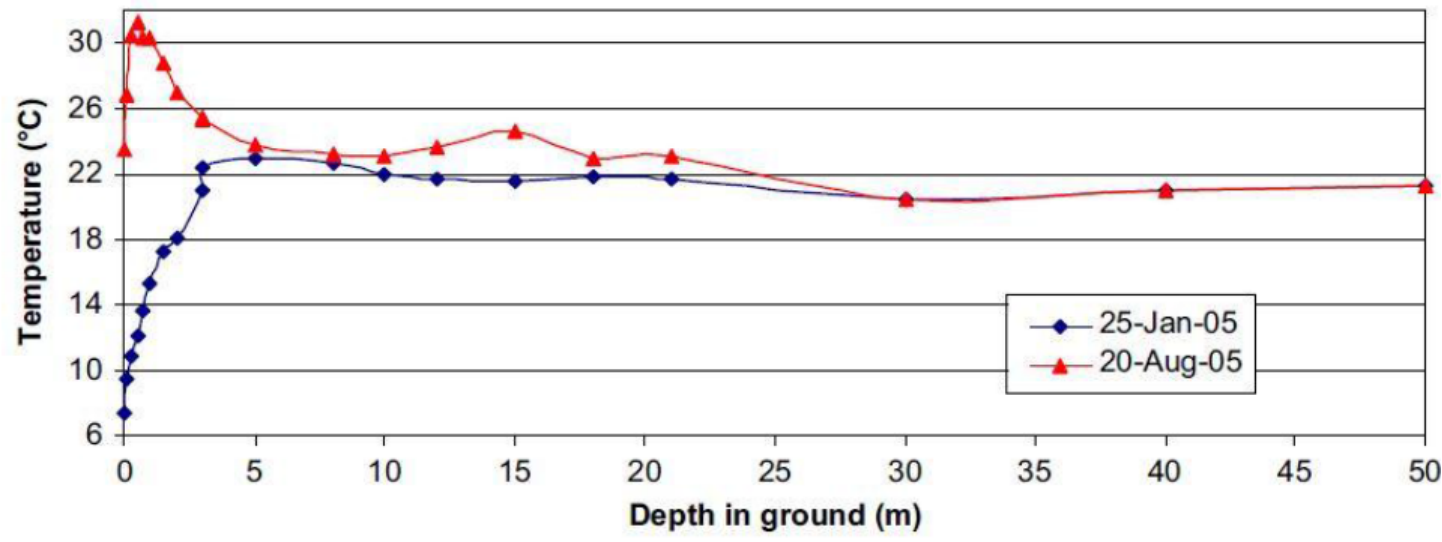

Figure 19: Study by Florides and Kalogirou, showing varying temperature with ground depth, indicating that ground temperature becomes constant at greater depths [44]

There are several options when considering ground source heat pumps systems. They can be vertically or horizontally oriented, and open or close loop. This report will focus on vertically oriented closed loop systems, due to their suitability for dense urban areas without access to moving water.

Vertical boreholes in southern Ontario can be drilled to 750 feet $(228 \mathrm{~m})$ - a depth at which they encounter bedrock, which is located deeper than 10 to $20 \mathrm{~m}$ below the surface, depending on the geology of the site [45]. In the Toronto region, the composition of bedrock is primarily shale and limestone, which have relatively good thermal conductivity for ground source heat pump 
applications [46] [47]. Since these holes are so deep, the vast majority of the borehole length will come into contact with thermally conductive and constant temperature ground.

Borefields can achieve different objectives, depending on their spacing in an array. The ASHRAE 2011 Geothermal Handbook states that a site which consumes an equal amount of heating and cooling energy on an annual basis, will experience an increase of $1.9^{\circ} \mathrm{C}$ in average ground temperature over a 10 -year period, when boreholes are spaced $4.5 \mathrm{~m}$ apart in a 10 by 10 grid, with a boreholes at a depth of $63 \mathrm{~m}$ [47]. Under these same conditions the average ground temperature will only increase by $0.6^{\circ} \mathrm{C}$ if boreholes are spaced $7.6 \mathrm{~m}$ apart [47].

If the amount of heat extracted from the ground is not equal to the amount of heat rejected to the ground annually, the average ground temperature will gradually increase or decrease. As seen in the example above, equal heating and cooling energy do not equate to a balanced ground. This is because the compressor does work which increases both the pressure and temperature of the refrigerant, proportional to the work input via electricity. This compressor heat allows less heat to be extracted from the borefield for heating but means that more heat must be rejected to the borefield for cooling, typically requiring $35 \%$ less heating than cooling.

As explained above, the effects of an imbalanced field can be mitigated by placing boreholes further apart. Conversely, if the design's objective is to thermally saturate the ground, boreholes should be placed close together.

Boreholes have also been used for thermal energy storage, in conjunction with GSHP systems. Waste heat or solar energy can be sent to the boreholes. During this process the heat from the boreholes will transfer to the surrounding earth, via conductive heat transfer, assuming there is no ground water movement or moisture vaporization. Overall, this will warm the ground and 
provide better source temperatures for the GSHP in heating mode because the temperature lift will be lower. This practice can be beneficial in heating dominated borefields.

A study done by Rad et al., investigated the use of borehole thermal energy storage for the intermittent heat output from solar thermal collectors. The modelling concluded that by the fifth year of operation, the community in question received a $96 \%$ solar fraction-only $4 \%$ of the heating energy was supplied by boilers [48].

Man, Yang and Wang conducted a borefield simulation, with year-round cooling in the Hong Kong climate [49]. The simulation compared a balanced GSHP system, achieved with a cooling tower to an unbalanced GSHP system. The results showed that the system prevented long term temperature increase in the boreholes, with fewer holes than the regular system [49]. The study concluded that the hybrid system reduced $34 \%$ of the initial cost and reduced the operating costs by $25-55 \%$ [49].

Johansson performed a study that evaluated the benefit of adding a dry cooler to a borefield that provided only cooling to a building year-round. The building in the study was located in Sweden, where the ground temperature is $6.6^{\circ} \mathrm{C}$ [50]. The building in the study produced a return temperature of $18^{\circ} \mathrm{C}$ and required a supply of $12^{\circ} \mathrm{C}$ directly to its fan coils. The study compared three scenarios on a lifecycle cost basis [50]. The base case scenario considers only a large borefield, used to dissipate all rejected heat. The "unloading" scenario considers a dry cooler that provides the entire cooling load of the building when the outdoor air is under a certain temperature, such as $8^{\circ} \mathrm{C}$. When outdoor air temperature is above $8^{\circ} \mathrm{C}$ the borefield has the capacity to meet all other cooling loads. The "recharging" scenario considers a dry cooler that can meet the cooling load at a $4^{\circ} \mathrm{C}$ outdoor air temperature [50]. The difference is that this dry cooler is programmed to 
provide $100 \%$ fan power when the outdoor air temperature is below $4^{\circ} \mathrm{C}$ [50]. This provides extra cooling that is directed to the borefield instead of the building, thereby balancing the borefield.

The unloading and recharging scenarios considered a fan shaped field, in which the bottom of the field does not overheat. The holes were angled at 15 and 20 degrees, making two concentric circles or holes. The holes fit inside a $14 \mathrm{~m}$ diameter circle and 20 were required, with $14 \mathrm{~cm}$ diameter [50]. Figure 20 shows the results of Johansson's borefield simulation for the unloading scenario, with $212 \mathrm{~m}$ boreholes after 20 years [50].

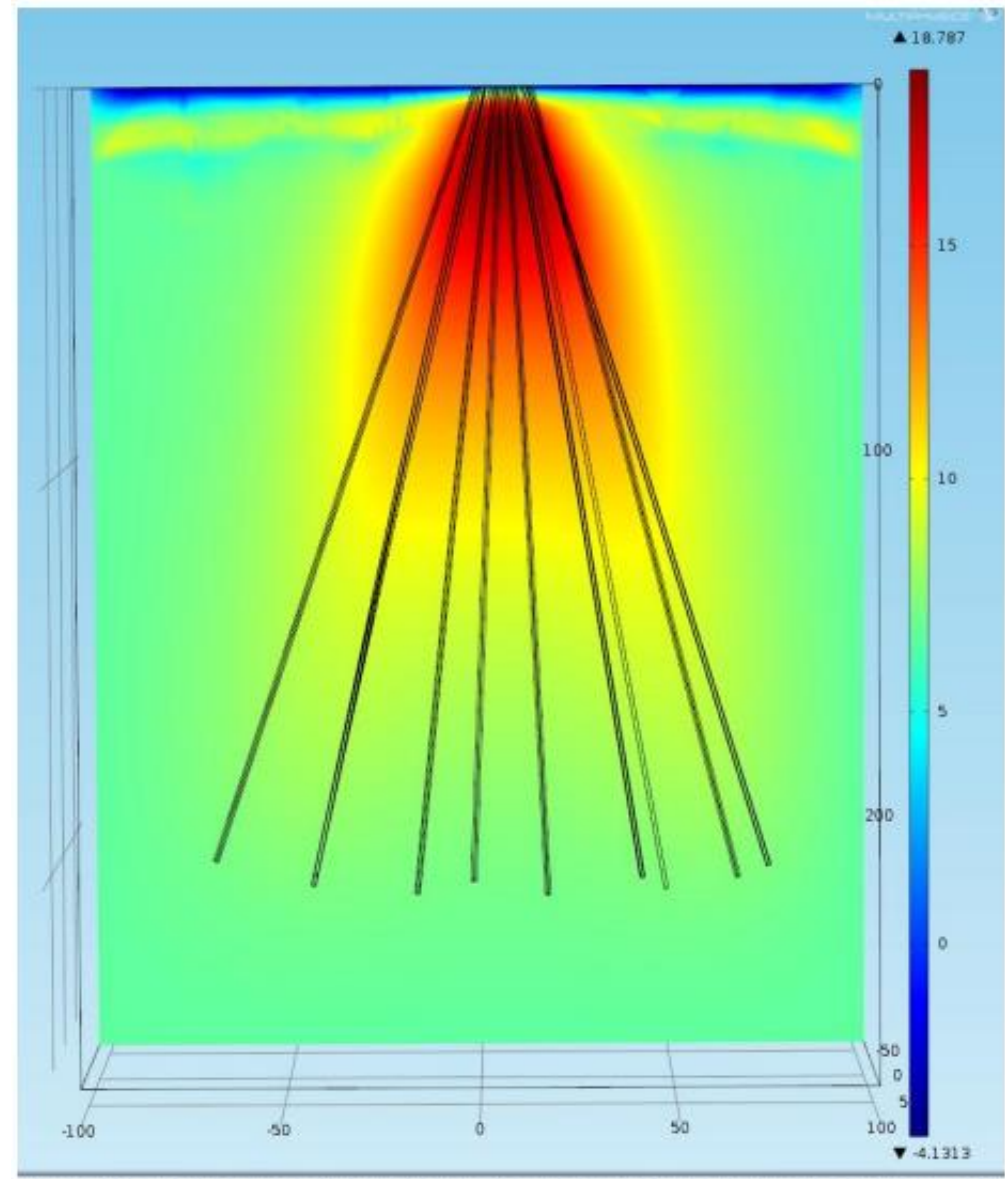

Figure 24: Temperature distribution in the ground for the first unloading case with 21 20 years.

Figure 20: COMSOL simulation by Johansson of temperature distribution in ground with unloading dry cooler and boreholes at $212 \mathrm{~m}$ depth after 20 years [50] 
Figure 21 shows the unloading scenario at varying borehole lengths. The fluid temperature increases over time because the borefield is not balanced. The dry coolers only offset $58 \%$ of the heat directed to the borefield [50]. A borefield, with borehole depth of $212 \mathrm{~m}$ was required to meet the building's specifications [50].

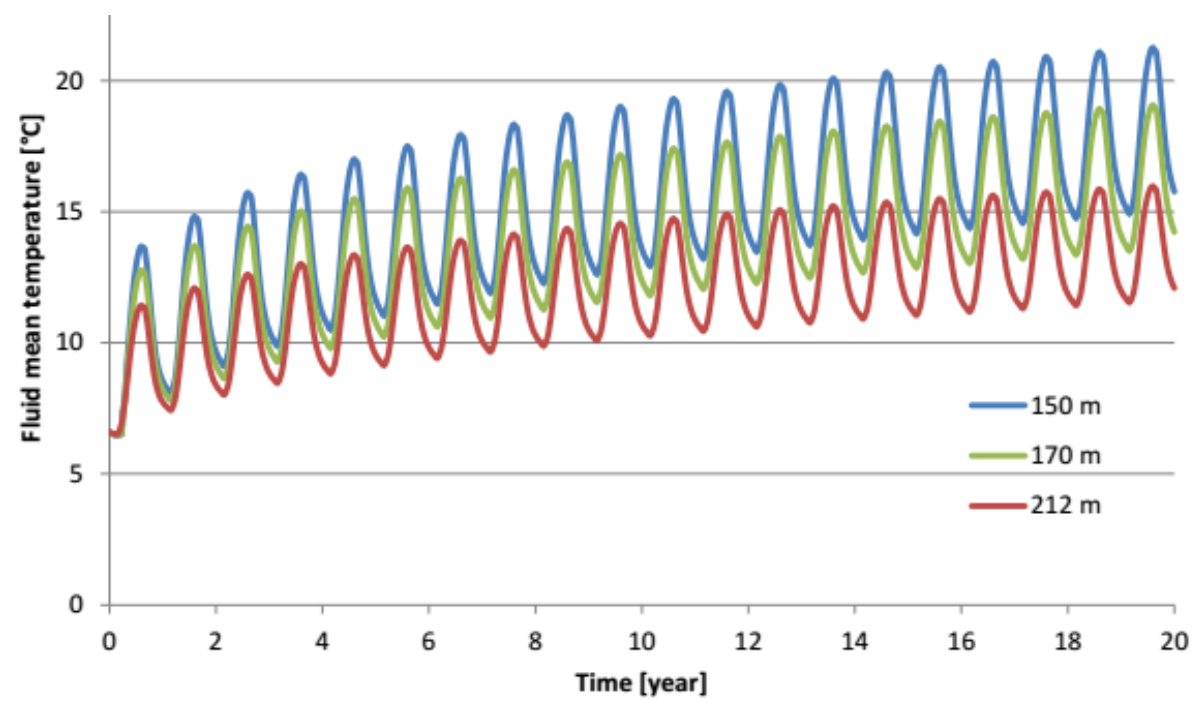

Figure 21: 20-year temperature profile of the mean fluid temperature exiting the borefield, considering an unloading dry cooler and varying borehole lengths [50]

Figure 22 shows the recharging scenario, which is $85 \%$ balanced [50]. The mean fluid temperature was able to remain relatively constant over the 20 -year simulation period, with a shorter borehole length than the unloading scenario, which saved capital.

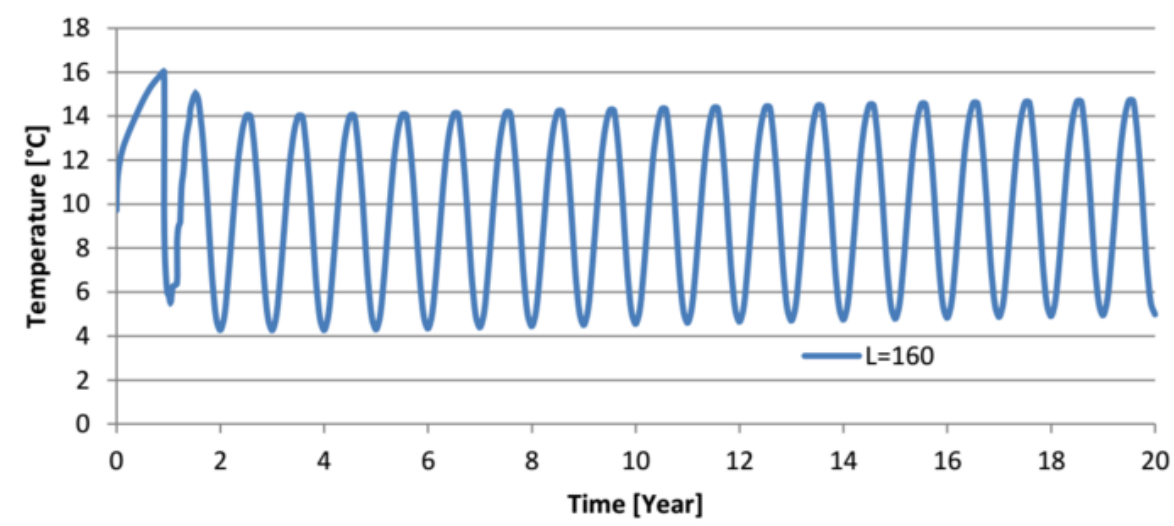

Figure 22: 20-year temperature profile of the mean fluid temperature exiting an $85 \%$ balanced, recharging borefield with $160 \mathrm{~m}$ deep holes [50] 
Figure 23 shows another version of the recharging scenario, which achieved a perfectly balanced borefield. Johansson chose to consider a $190 \mathrm{~m}$ borehole depth instead of $160 \mathrm{~m}$, to avoid providing freezing temperatures to the building's fan coils. This appears to have wasted capital because glycol would have prevented the water from freezing.

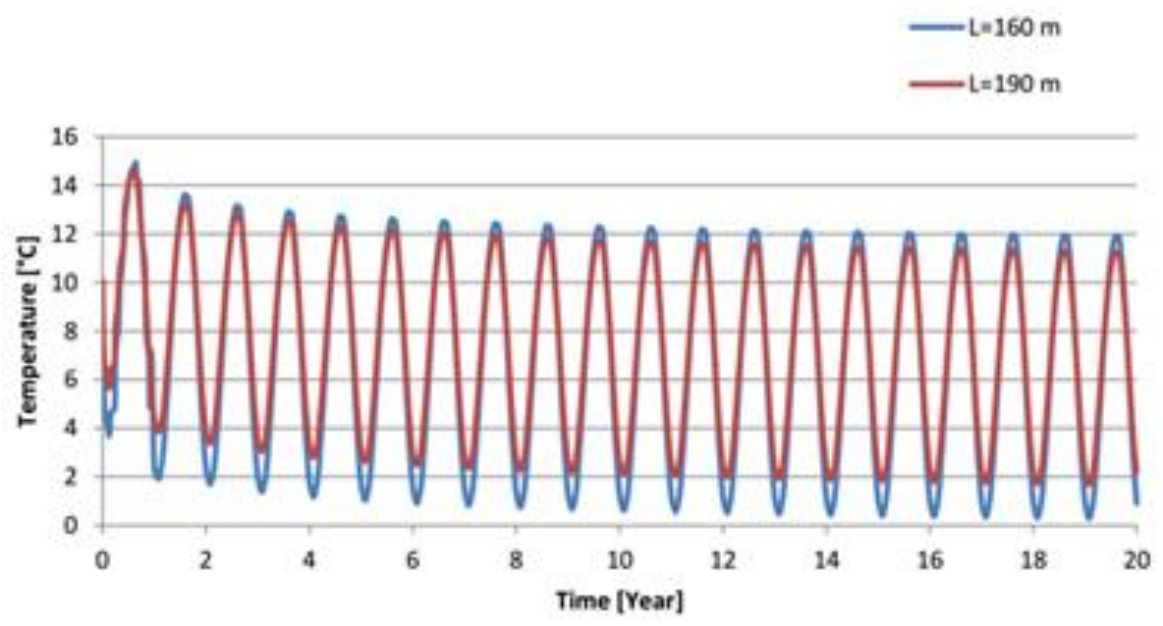

Figure 23: 20-year temperature profile of the mean fluid temperature exiting a 100\% balanced, recharging borefield with varying borehole lengths [50]

The study concluded that the unloading scenario had the lowest lifecycle cost; however, the recharging scenario's lifecycle cost was only $11 \%$ higher. This study has made a strong case for using dry coolers to supplement a borefield used for cooling. It is also shown that it is possible to cool a building without using a ground source heat pump. In the Toronto climate, the recharging scenario may be more attractive because the ground is warmer. An unbalanced borefield may not be able to achieve a $12^{\circ} \mathrm{C}$ supply temperature, because the ground temperature is $10^{\circ} \mathrm{C}$.

\subsection{Existing Data Centre Waste Heat Recovery in District Energy Systems}

Davies et al. performed an investigation of data centre waste heat recovery opportunities in London, England. First, the study found that the best way to recover waste heat from a data centre was to use it in building heating systems, or direct it to a district energy network [51]. Second, the study identified that it is possible to recover heat from both chilled water return and 
the return air to CRAH units [51]. The schematic of the air source heat recovery system is shown in Figure 24. The COPs of single stage heat pumps, with chilled water return and CRAH return air waste heat stream sources, where estimated with Coolpak refrigeration system simulation software. The chilled water source was simulated to achieve a $3.1 \mathrm{COP}$, with an evaporator entering temperature of $20^{\circ} \mathrm{C}$ and leaving temperature of $10^{\circ} \mathrm{C}$ and a condenser leaving temperature of $70^{\circ} \mathrm{C}[51]$. The return air source was simulated to achieve a 4.1 COP, with an evaporator entering temperature of $35^{\circ} \mathrm{C}$ and leaving temperature of $25^{\circ} \mathrm{C}$, with the same condenser leaving temperature [51].

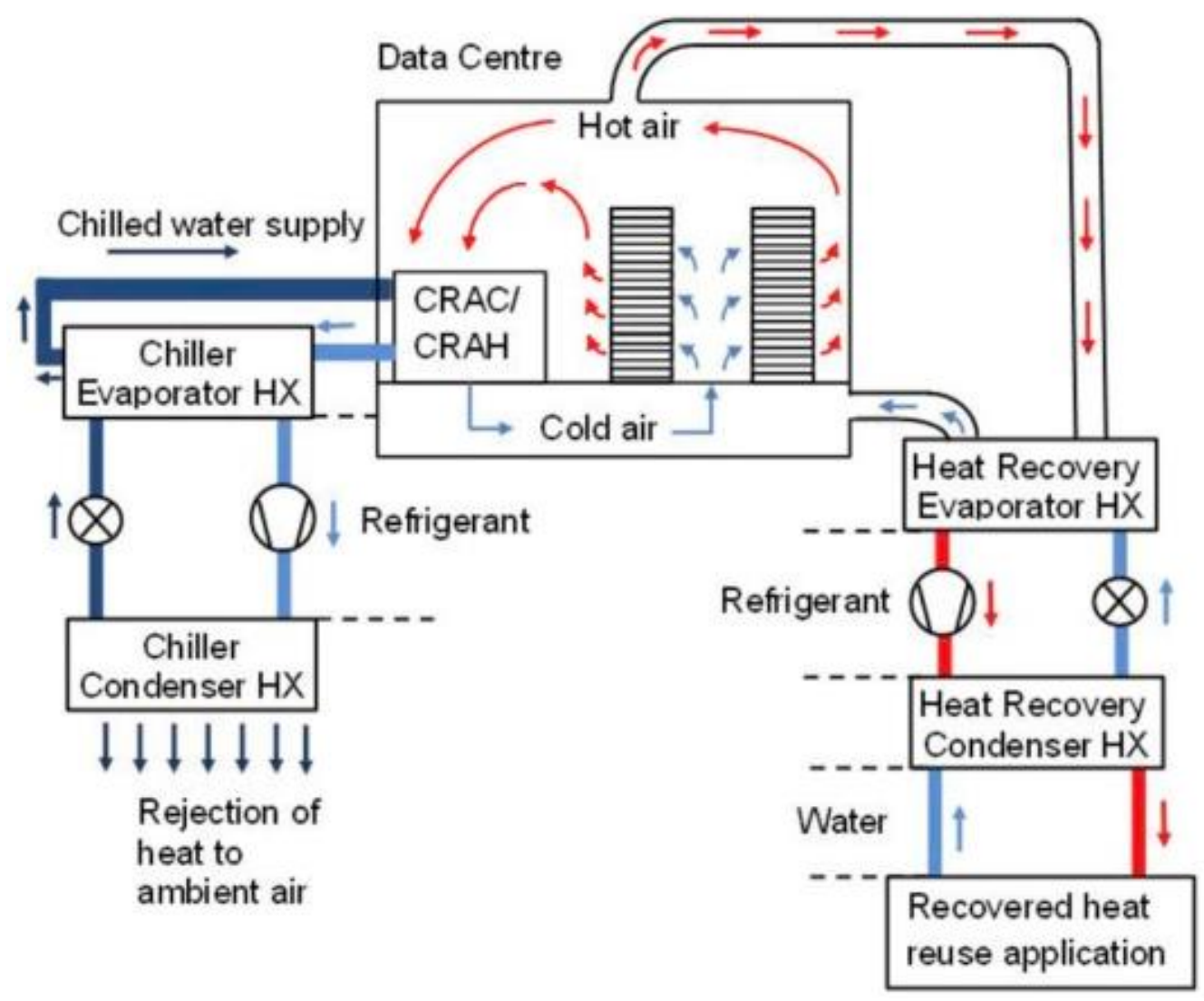

Figure 24: Heat recovery from CRAH return air in data centre, using an air source heat pump [51]

Davies et al. performed an analysis considering a 3.5MW IT constant load data centre interfacing with a district heating network, which demanded 3.5MW of heat, year-round. The 
chilled water source achieved 2.76 MW years of energy savings, while the air source achieved 3.04 MW years of energy savings [51]. This was calculated assuming that 3.5 MW years of heat generation is avoided, and considering the heat pump and pumping electricity consumption. The cost savings is calculated, considering the avoided cost of providing heat via natural gas, at $£ 0.04 / \mathrm{kWh}$ with a $90 \%$ efficiency subtracted by the electricity operating cost of the heat pump, at $£ 0.10 / \mathrm{kWh}[51]$. The cost savings of the air source waste heat is higher in Table 3 because of the heat pump required less electricity.

Table 3: Comparison by Davies et al. of using chilled water return or CRAH return air as a waste heat source for district energy systems on an energy, environmental and financial basis [51]

\begin{tabular}{|c|c|c|c|}
\hline Heat Source & Energy Savings (MWh) & Carbon Savings (tonnes) & Cost Savings (f) \\
\hline Chilled Water & 24,178 & 1864 & $£ 373,634$ \\
\hline Air & 26,630 & 2938 & $£ 614,862$ \\
\hline
\end{tabular}

There are potential gaps in this study that can be filled. First, the capital cost of the retrofits, or the equipment, are not considered in the financial analysis. Second, the cooling energy and cost savings are not considered for the data centres. Third, the data centres' IT load and waste heat output are assumed to be constant over the entire year. This assumption may be adequate for means of comparison, but varying waste heat output as well as varying heat demand should be considered when determining the correct magnitude of energy and cost savings.

Ebrahimi et al. also identified district heating networks as good users of waste heat from data centres [52]. Similar to the Davies et al. study, Ebrahimi et al. identified CRAH unit return air and chilled water return as the best places to capture waste heat [52].

\subsubsection{Open District Heating}

Open District Heating, a Swedish district energy company, is a prime example of data centres being used for their waste heat. This company is connected to four different data centres, 
all with varying connection configurations. Two of these connection designs will be investigated in Chapter 3.

Bahnhof, an internet provider company has a data centre in central Stockholm that is connected to Open District Heating's cooling and heating network, shown in Figure 25. The chiller in this data centre is replaced by a heat exchanger. This heat exchanger simply transfers the energy from the district chilled water loop to the data centres chilled water loop. This reduces the temperature of the return water from the CRAH units to the proper supply temperature. In transferring the energy within the chilled water, the district cooling loop water is warmed. This water is sent to the evaporator side of three Carrier 30XWH 802-HT heat pumps that produce chilled water on the evaporator side and hot water on the condenser side [53]. The data centre outputs $1,189 \mathrm{~kW}$ of cooling at $5.5^{\circ} \mathrm{C}$ and $1,583 \mathrm{~kW}$ of heating at $68^{\circ} \mathrm{C}$ during normal operation [53]. The cost of the three heat pumps, along with controls and installation was $\$ 790,000 \mathrm{CAD}$ [53].

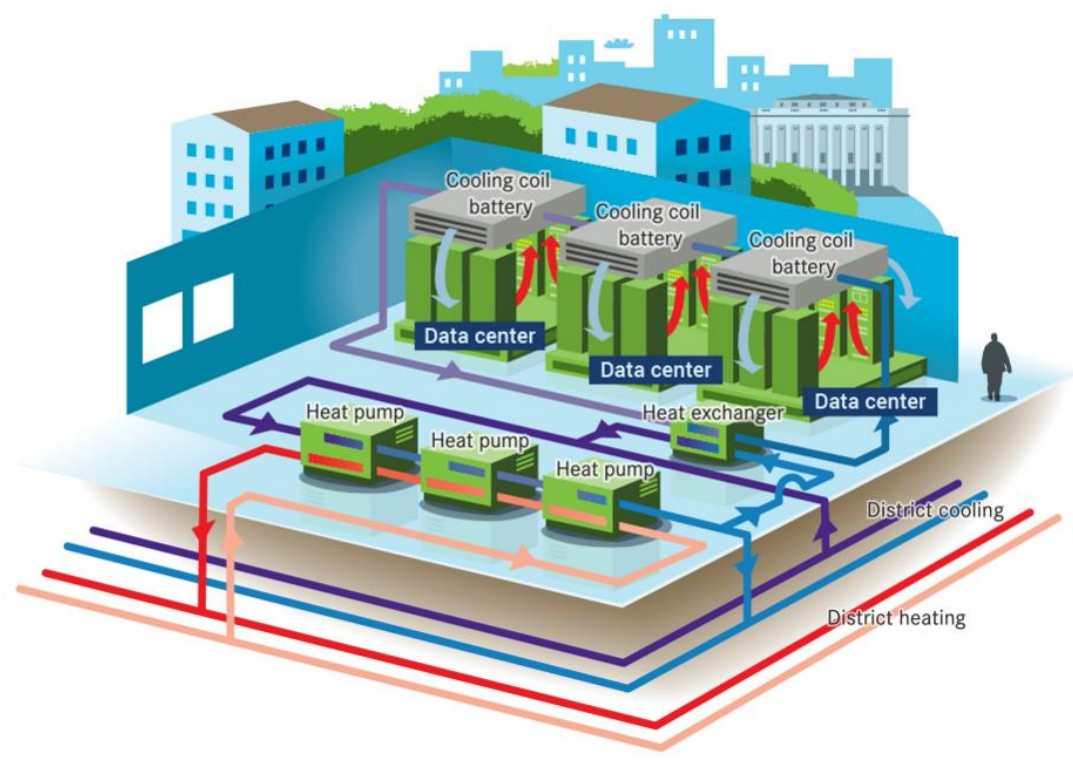

Figure 25: Design for integrating a data centre into a district heating and cooling system [53] 
Another Bahnhof data centre in Stockholm has two Carrier 30XWH 802-HT heat pumps that replace the data centre's chiller, shown in Figure 26 [54]. The condenser side of this series of heat pumps produces hot water for the district heating loop. The heat pumps can produce $649 \mathrm{~kW}$ of cooling and $975 \mathrm{~kW}$ of heating [54]. This data centre normally produces $600 \mathrm{~kW}$ of heating at $68^{\circ} \mathrm{C}$ [54]. The cost of the heat pumps, along with controls and installation was $\$ 510,000 \mathrm{CAD}$ [54]. The data centre's existing chiller is kept as back up, along with the cooling tower.

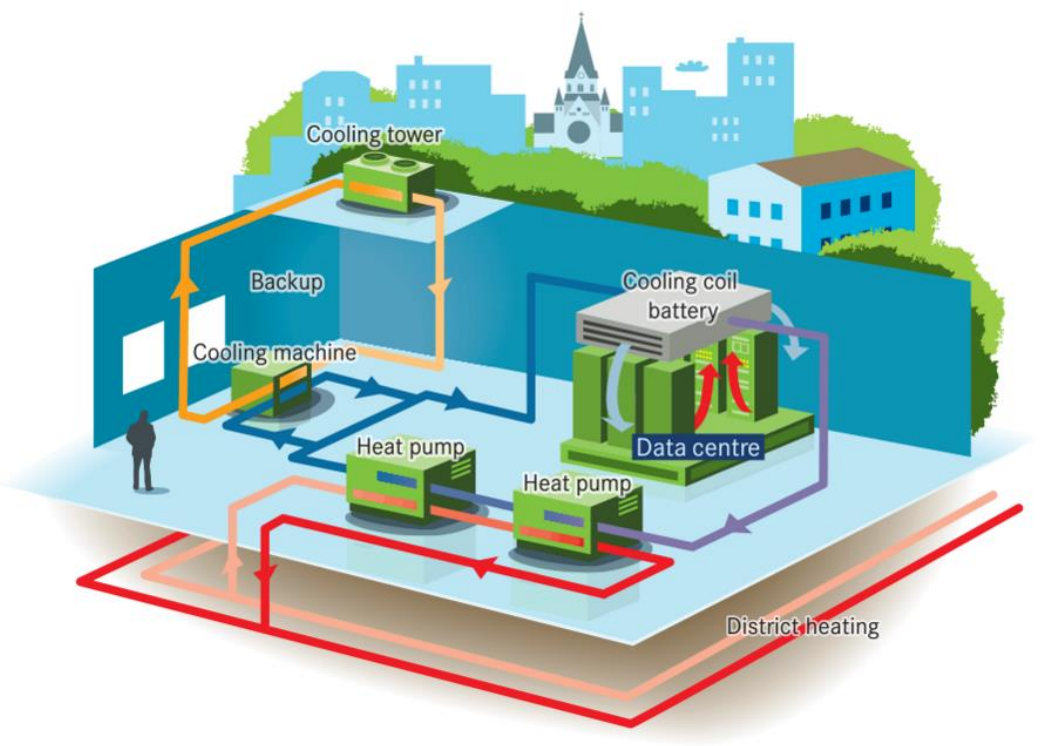

Figure 26: Design for integrating a data centre into a district heating system [54]

The relationship between the data centres and Open District Heating is profitable for both parties. The company has a demand-based pricing system with the data centres. The cost of the waste heat can be 10 times more expensive in the peak of the winter, than the summer [53].

\subsubsection{Enwave Seattle}

Enwave Seattle has completed a data centre heat recovery project, in which the district energy company partnered with an extremely large 11 MW IT load data centre to deliver heat to three Amazon office buildings [55]. Heat recovery chillers are staged between the data centre and the Amazon office buildings. The data centre is shown on the left of Figure 27, while the Amazon 
buildings are on the "future district energy connection", located to the right, out of the schematic. When a signal indicates that Amazon's building require heat, chilled water pumps are activated to transport return water from the data centre at $70^{\circ} \mathrm{F}$ to the evaporator side of heat recovery chillers [56]. The evaporator side of the heat recovery chillers produce chilled water for direct use in the data centre's fan coil units, while the condenser side heats return water from the radiant floor heating systems in Amazon's buildings.

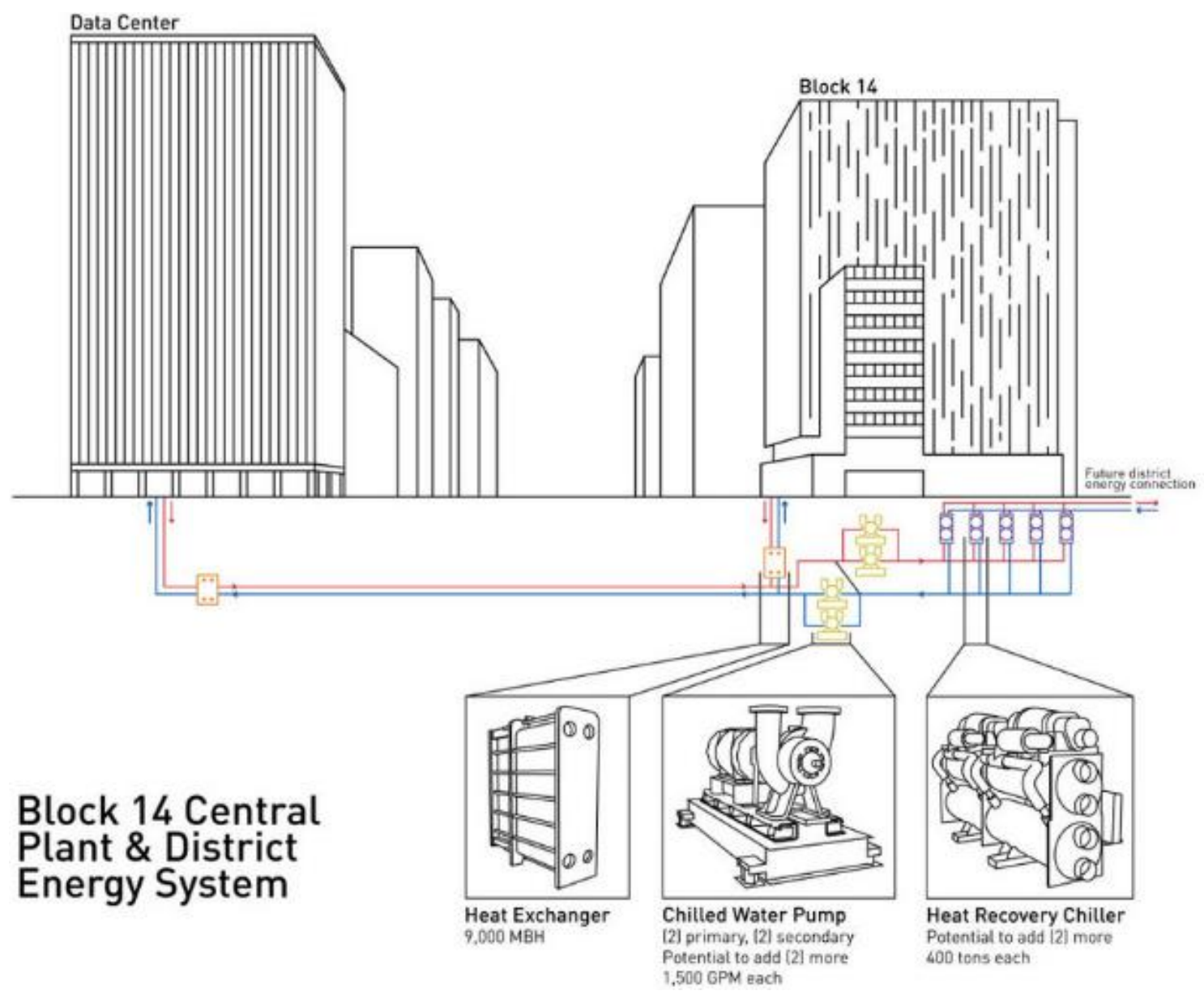

\section{Figure 27: Westin Building data centre connected to Enwave Seattle's local district energy system [55]}

The highly successful project started operating as of January 2016 [55]. The data centre has been able to deliver over 4 million kWh per year of waste heat to Amazon's 3 million square feet of office space at a load of up to 5MW [55] [56]. Additionally, the data centre saves 100,000 
gallons of water per day as well as electricity, from running their cooling towers less often [55]. Richard Stevenson, president of Clise properties, which owns the data centre claimed that the project required several millions of dollars in capital, but that it was easy to financially justify [56].

\subsubsection{Yandex Data Centre}

Yandex, a Russian search engine and internet service company, installed a data centre that recovers waste heat in Mäntsälä, Finland, in 2014 [57]. The system's current design does not use a chiller, rather, it passively cools the building by positioning it in the face of the prevailing wind, as shown in Figure 28 [58] [57]. The data centre's IT load is 6 MW and it currently sells approximately 3.6 MW of waste heat, totaling $20 \mathrm{GWh}$ per year [58].

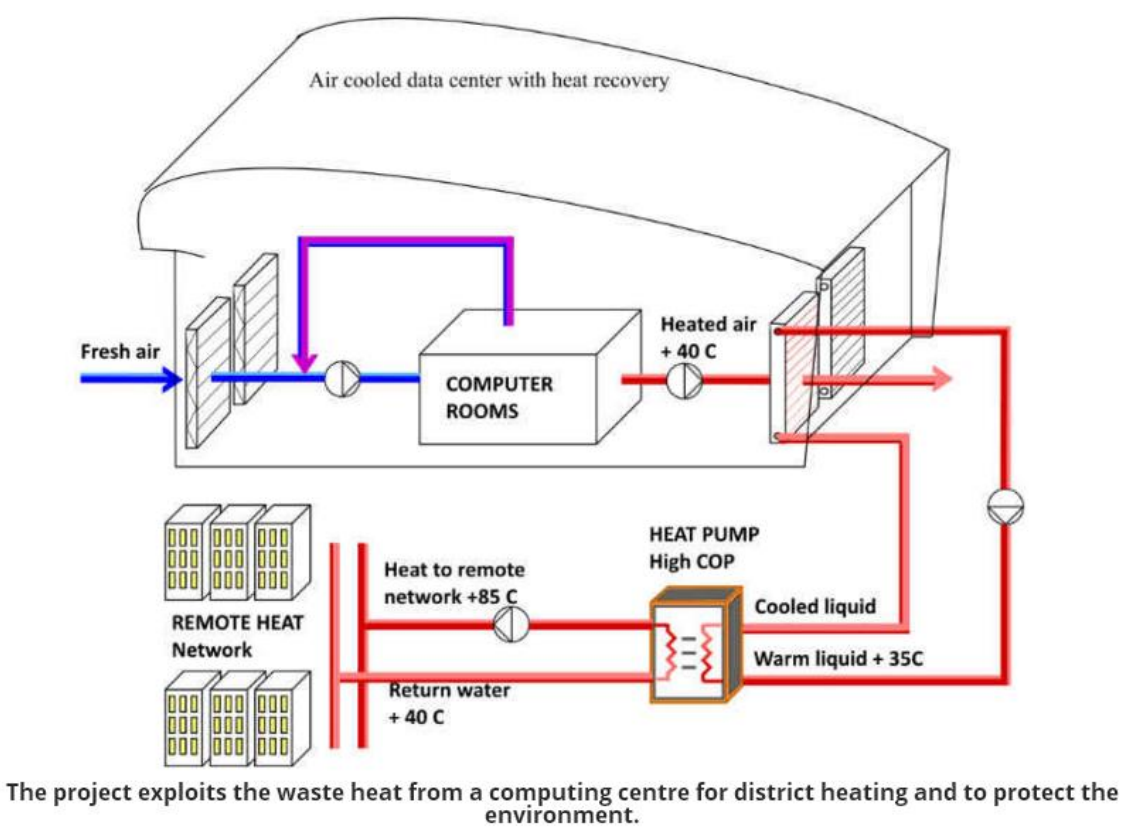

Figure 28: Schematic of Yandex's data centre heat recovery system in Finland [57]

The warm $40^{\circ} \mathrm{C}$ air is passed through water coils which heat to $35^{\circ} \mathrm{C}$ [57]. Twenty four 6cylinder ECOLINE heat pumps manufactured by Bitzer, with a total capacity of 4MW, upgrade the water temperature to $85^{\circ} \mathrm{C}$ and direct it to the local town's district heating network, $200 \mathrm{~m}$ away, shown in Figure 29 [57]. 


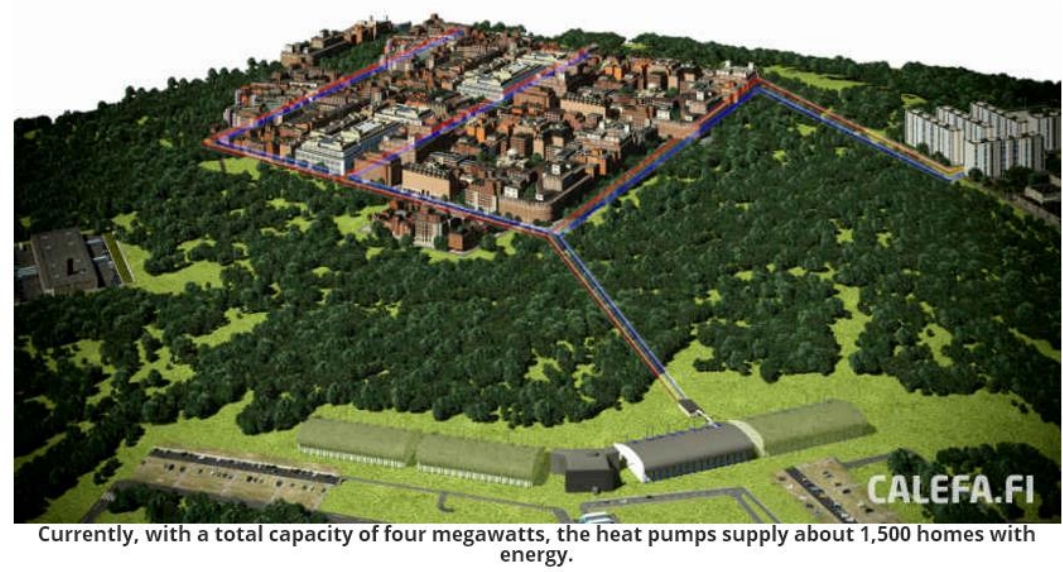

Figure 29: Illustration of the proximity of Yandex's data centre to the local district heating network [57]

The project has reduced the data centres $\mathrm{CO}_{2}$ emissions by $40 \%$, or 4000 tonnes annually [57]. The data centre plans to gain more IT load before the project is completely finished, enough to save 11,000 tonnes of $\mathrm{CO}_{2}$ and sell heat to 4000 homes, compared to the current 1500 [57].

The heat recovery unit inside the data centre did not disrupt the data centre's operations, and was installed quickly. The only change to the data centre was a small amount of extra fan power to draw warm air to the heat recovery unit [58]. The heat pump unit and the piping were installed outside the data centre.

Overall, this project was very successful, and the operators claim that selling waste heat is the best way to reduce operating costs of the data centre [58]. Most data centres are focused on improving their power usage effectiveness (PUE), which is a metric that assesses the amount of extra power used that is not for IT equipment. Data centres that are already efficient will experience diminishing returns in attempting to improve their PUE [58]. Yandex's data centre manager, Ari Kurvi, believes the data centre ultimately benefitted from the tradeoff of allowing a slightly worse PUE in exchange for selling waste heat [58]. 


\section{CHAPTER III - Comparison of Energy Sharing Scenarios}

Corresponding Manuscript: A.R. Murphy, A.S. Fung, "Techno-Economic Study of an Energy

Sharing Network Comprised of a Data Centre and Multi-Unit Residential Buildings for Cold

Climate", Energy and Buildings, Submission Date: July 31 ${ }^{\text {st }}$, 2018, Manuscript Reference:

ENB_2018_2362.

\subsection{Introduction}

Data centres require cooling year-round even in cold climates. This is because the cooling requirement of a data centre is equal to the electrical load of its server equipment. This means that data centres normally produce more heat than can be used in one building alone. Typically, this excess heat is released to the atmosphere via cooling towers. Since this waste heat can be utilized by more than one building the logical approach is create a community or district energy network that is tailored to utilize all of the available low carbon heat. The analysis in this chapter will focus on determining the best way to create a new community energy network that is designed for using data centre waste heat.

\subsubsection{Successful Implementation}

A data centre heat recovery to district energy system has been successfully completed in the past. Fortum, a Swedish district energy company has completed four projects in which they have integrated a data centre into their district heating network and in one of the cases their district cooling network as well [59] [53]. Enwave Energy Corporation, a North American district energy provider, has started construction on a system to recover heat from an $11 \mathrm{MW}$ IT load data centre in Seattle, for use in their district heating network [55]. Yandex, a Russian search engine, connected a 6 MW IT load data centre to a Finnish district heating network, where it sells 3.6 MW of waste heat [58]. Davies et. al. studied the potential for data centre waste heat recovery in London, England and concluded that the best sources of heat are in the chilled water return or the computer room air handling $(\mathrm{CRAH})$ unit return air [51]. This was further supported by Ebrahimi et al. [52]. Among all the aforementioned projects and studies, a study of data centre heat recovery 
for district energy systems has never been conducted with geo-exchange for thermal energy storage.

\subsection{Methodology}

The methodology for this analysis consisted of a three-step process of:

1. Preparing load profiles.

2. Modelling performance and sizing equipment.

3. Conducting a financial analysis.

Hourly cooling data was collected from an operating data centre in Toronto, which included chilled water supply and return temperatures as well as equipment efficiencies. Next, the optimal amount of heating demand that should be connected to this given data centre was determined using the iterative equation solver: Goal Seek function in Microsoft Excel. The optimal portion of peak capacity that should be met by the community energy network (CEN) for both the data centre and the MURBs (which is the largest amount of energy for the smallest capacity) was determined by graphing the energy met at various capacity levels and finding the point where capacity is low and at least $80 \%$ of energy is met. Once the capacity level that will be provided by the community energy network was determined new load profiles were created. With these new load profiles, the amount of heat that can be shared from the data centre to the MURBs, during periods when the data centre's cooling demand and the MURBs' heating demand coincide was determined.

Equipment modelling for the Energy Sharing and One-Borefield System was conducted in GLD [60], while TRNSYS [61] was required to model the unique scenario presented in the TwoBorefield System. GLD was used as the preferred modelling program because it allows selection 
of a wide range of water to water heat pumps, while the TRNSYS package includes coefficients for just one type of heat pump in either one or two stages.

A financial model was created in Microsoft Excel to optimize capital cost and operating efficiency, with the objective of maximizing IRR. IRR was used as a final comparison between the three scenarios to determine which is the most likely to be adopted. The amount of funding required to make a scenario meet a minimum $8 \%$ IRR divided by the total project life GHG emissions reduction was also used as a means of comparison. An $8 \%$ IRR is considered as the minimum IRR for project investment in the district energy industry.

\subsection{Scenario 1 - Energy Sharing System}

Figure 30 illustrates the Energy Sharing System, where $\mathrm{T}_{\mathrm{CHws}}$ and $\mathrm{T}_{\mathrm{CHWR}}$ are the chilled water supply and return temperatures for the data centre's fan coils and $\mathrm{T}_{\mathrm{HWS}}$ and $\mathrm{T}_{\mathrm{HWR}}$ are the heating water supply and return temperatures for the MURBs' fan coils. A new pipe can be implemented that taps off the data centre's chilled water return pipe so that it can deliver warm fluid to a new heat pump. This heat pump then provides adequate heating temperatures for the residential building, while also cooling down the chilled water return fluid and sending it back to the data centre's fan coils. This process is minimally invasive to the data centre because it is a fully redundant system. It can be shut off at any time.

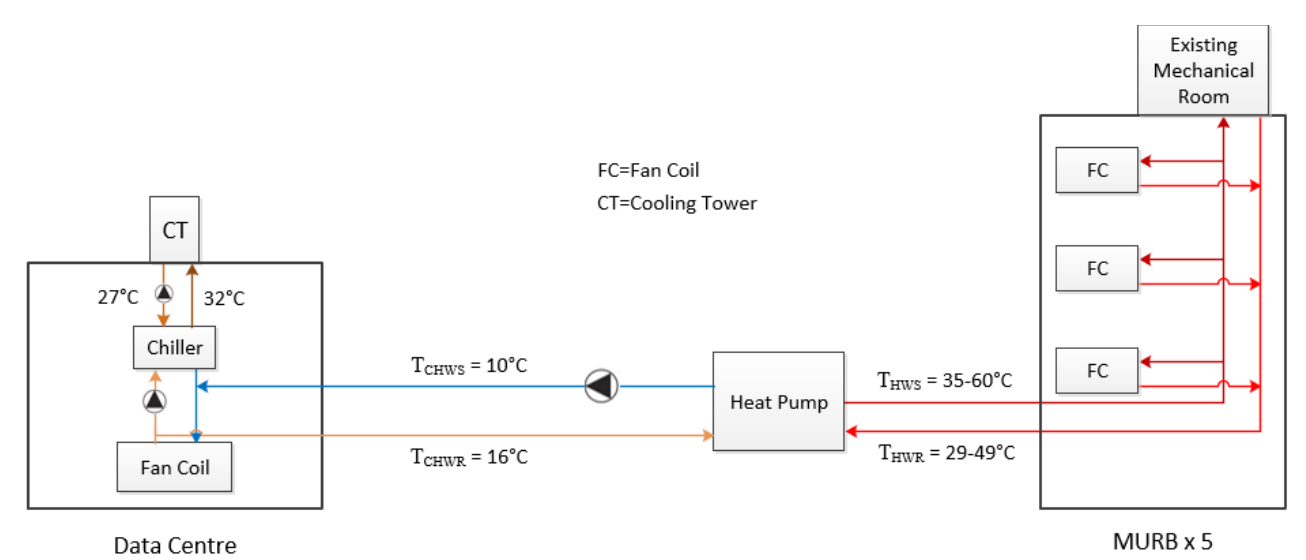

Figure 30: Energy Sharing System schematic 


\subsubsection{Defining the Buildings}

A common HVAC arrangement for mid-rise MURBs in Toronto is the two-pipe fan coil system [62]. This system typically has a penthouse mechanical room with a boiler and chiller, $\mathrm{T}_{\text {CHWR }}$ which heat and cool water before it is distributed down to fan coils in each suite. The twopipe arrangement means that space heating and cooling cannot happen at the same time.

The efficiency of the heat pump shown in Figure 30 is highly dependent on the heating supply and return water temperatures. ANSI/AHRI Standard 440-2008 states that design day heating supply temperature to fan coils are typically $60^{\circ} \mathrm{C}$ [63]. Heating supply temperature can also be scaled back in part load scenarios, according to Table 4 , where the $\%$ of Fan Coil Rated Capacity is the output capability of the fan coil at a particular heating supply temperature [64]. The $\%$ of Rated Fan Coil Capacity is matched to the percentage of heating peak at the MURBs on the 8760 hourly load profile to determine the required heating supply temperature at each hour.

The Trane RTWD heat pump can produce condenser water temperatures up to $60^{\circ} \mathrm{C}$ [65]. Table 4 also shows the corresponding differential temperature (or $\Delta \mathrm{T}$ ) at the same supply temperatures as the Bosch table [65]. Condenser fluid flow (m) and the temperature difference $(\Delta T)$ between the heating water supply and return can be used to calculate the heating load delivered to the building, using Equation 2.

$$
Q=\dot{\mathrm{m}} C_{P}\left(T_{H W S}-T_{H W S}\right)
$$

Table 4: Bosch fan coil correction factors for fan coil output capacity at different heating supply temperatures

\begin{tabular}{|c|c|c|c|c|c|c|}
\hline $\mathrm{T}_{\mathrm{HWS}}\left({ }^{\circ} \mathrm{C}\right)$ & 35 & 40 & 45 & 50 & 55 & 60 \\
\hline \% of Fan Coil Rated Capacity & $36 \%$ & $49 \%$ & $62 \%$ & $74 \%$ & $87 \%$ & $100 \%$ \\
\hline $\begin{array}{c}\text { Trane RTWD Heat Pump } \\
\text { Condenser } \Delta T\left({ }^{\circ} \mathrm{C}\right)\end{array}$ & 6 & 7 & 8 & 9 & 10 & 11 \\
\hline
\end{tabular}


Data centres also use fan coil units to deliver cooling energy to server rooms. Chilled water supply temperature is typically $10^{\circ} \mathrm{C}$ supply and $16^{\circ} \mathrm{C}$ return [12].

The COP of the Trane heat pump was simulated hourly with GLD and TRNSYS, considering the required heating water supply temperatures at the corresponding load levels. The weighted average condenser water leaving and entering temperatures were $39^{\circ} \mathrm{C}$ and $32^{\circ} \mathrm{C}$, respectively. The weighted average COP of the RTWD heat pump, sourcing from the $16^{\circ} \mathrm{C}$ chilled water return temperature, was 4.3 .

Domestic hot water is required to be heated to $60^{\circ} \mathrm{C}$ according to Ontario Building Code [25]. During periods when the heating demand allows for supply water temperatures of less than $60^{\circ} \mathrm{C}$, the existing boilers in the MURBs can increase the DHW temperature to $60^{\circ} \mathrm{C}$ by adding an amount of energy proportional to the remaining temperature lift required. Equation 3 is the formula used to calculate the proportion of domestic hot water energy supplied by the community energy network $(\mathrm{CEN})$, where $\mathrm{T}_{\mathrm{DHW}}$ is the DHW temperature of $60^{\circ} \mathrm{C}, \mathrm{T}_{\mathrm{HWS}}$ is the heating water supply temperature to the MURBs' fan coils, ranging from $35-60^{\circ} \mathrm{C}$ and $\mathrm{T}_{\mathrm{CW}}$ is city water delivered to each MURB assumed at $5^{\circ} \mathrm{C}$. This method was used to apportion the amount of domestic hot water energy delivered by the CEN in the financial model.

$$
\frac{C E N}{\text { Total DHW Energy }}=\frac{\dot{\mathrm{m}} C_{P}\left(\mathrm{~T}_{H W S}-\mathrm{T}_{C W}\right)}{\dot{\mathrm{m}} C_{P}\left(\mathrm{~T}_{D H W}-\mathrm{T}_{C W}\right)}
$$

\subsubsection{Load Profiles}

Figure 31 highlights the optimization of the amount of heating demand connected to the given data centre. The MURB heating energy model was scaled by square footage to represent different levels of heating demand, while the size of the data centre and therefore its cooling load was kept constant. The point where both the MURBs and the data centre had the largest percentage of energy sharing was a multi-unit residential building area of $110,000 \mathrm{~m}^{2}$, or five buildings at 
approximately $22,000 \mathrm{~m}^{2}\left(240,000 \mathrm{ft}^{2}\right)$ each. This point where energy sharing is maximized is the point where profitability is maximized because of energy sharing's highly efficient operation.

Equation 4 was used in Excel to calculate QES n, the amount of energy sharing in each hour of the 8760 load profiles, where QMURB $_{n}$ is the MURBs' total heating load in a given hour and QDC $\mathrm{n}$ is the data centre's total cooling load in a given hour. Equations 5 and 6 define the energy sharing percentage for the MURBs and the data centre.

$$
\begin{gathered}
Q_{E S n}=I F\left(Q_{M U R B n}>Q_{D C n}, Q_{D C n}, Q_{M U R B n}\right) \\
E S \%_{M U R B}=\frac{\sum_{n=1}^{8760} Q_{E S n}}{\sum_{n=1}^{8760} Q_{M U R B}} \\
E S \%_{D C}=\frac{\sum_{n=1}^{8760} Q_{E S n}}{\sum_{n=1}^{8760} Q_{D C n}}
\end{gathered}
$$

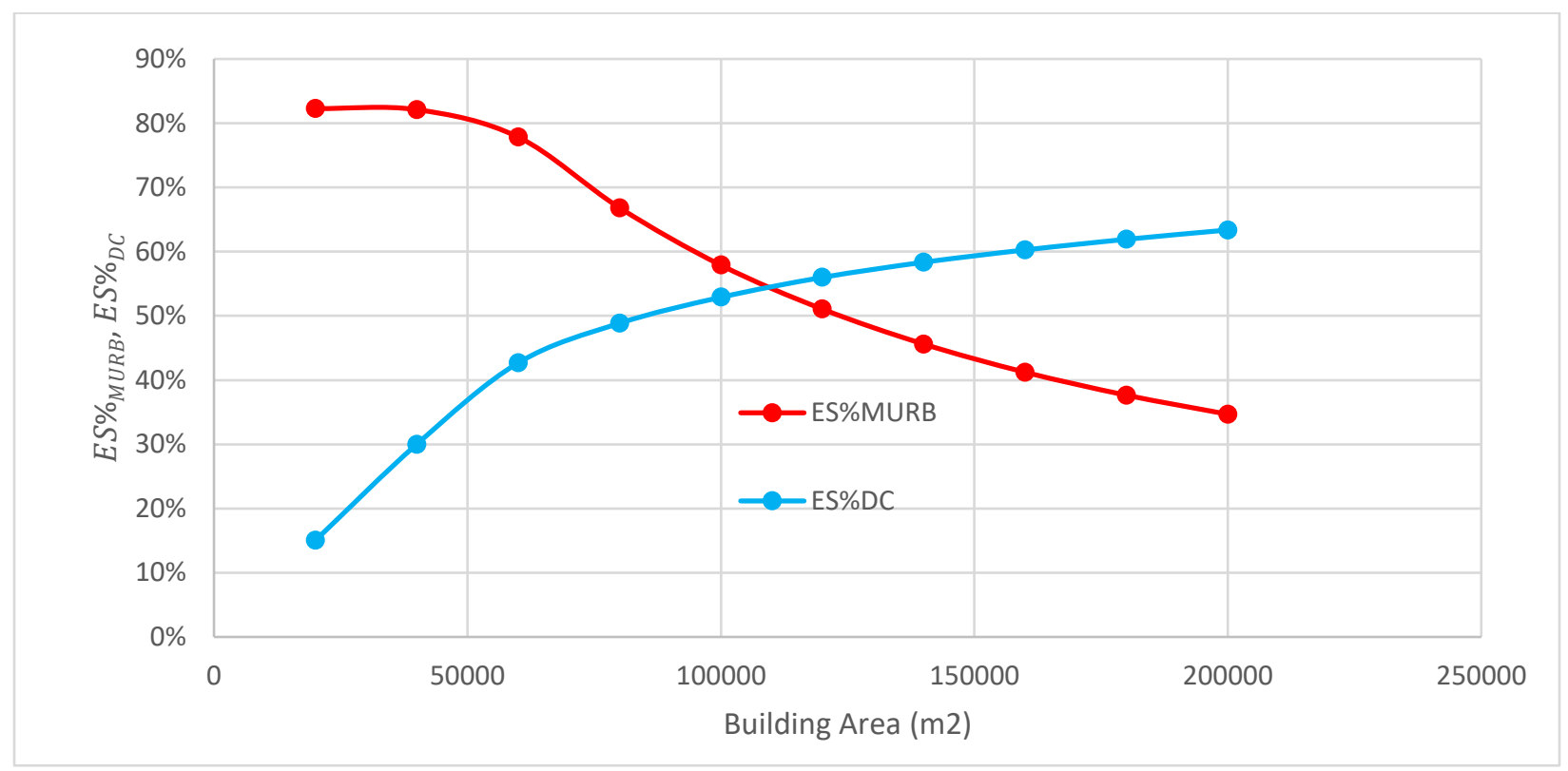

\section{Figure 31: Optimization of MURB area, by finding the maximum percentage of energy sharing}

Figure 32 presents the combined MURB heating load profile, with no consideration for load diversity between buildings, as the full height of the bars. The red portion is made up with existing boiler capacity at each building and the green portion is met by shared energy. Domestic hot water accounts for the heating load during the summer. 


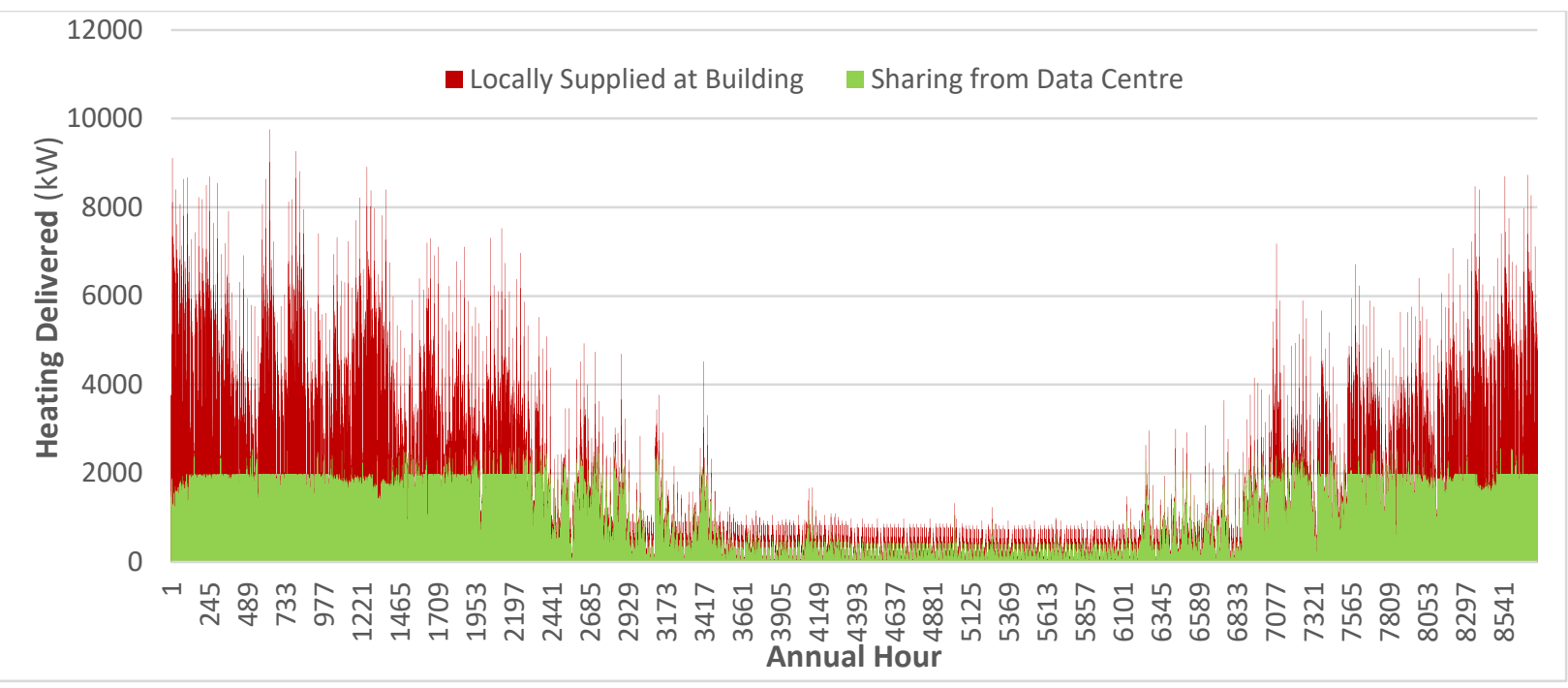

Figure 32: MURB heating load profile, showing loads met by energy sharing

Figure 33 depicts the data centre cooling load profile, as the full height of the bars. The blue portion is made up with existing chiller capacity at the data centre and the green portion is met by shared energy. Energy sharing during the summer is due to DHW loads at the MURBs. MURBs require more DHW than commercial buildings, making them a better choice for energy sharing. This data centre is typical, in that it experiences nearly constant cooling demand, with a very modest increase in cooling demand during the summer. This flat profile is the reason why energy sharing with data centres is so effective.

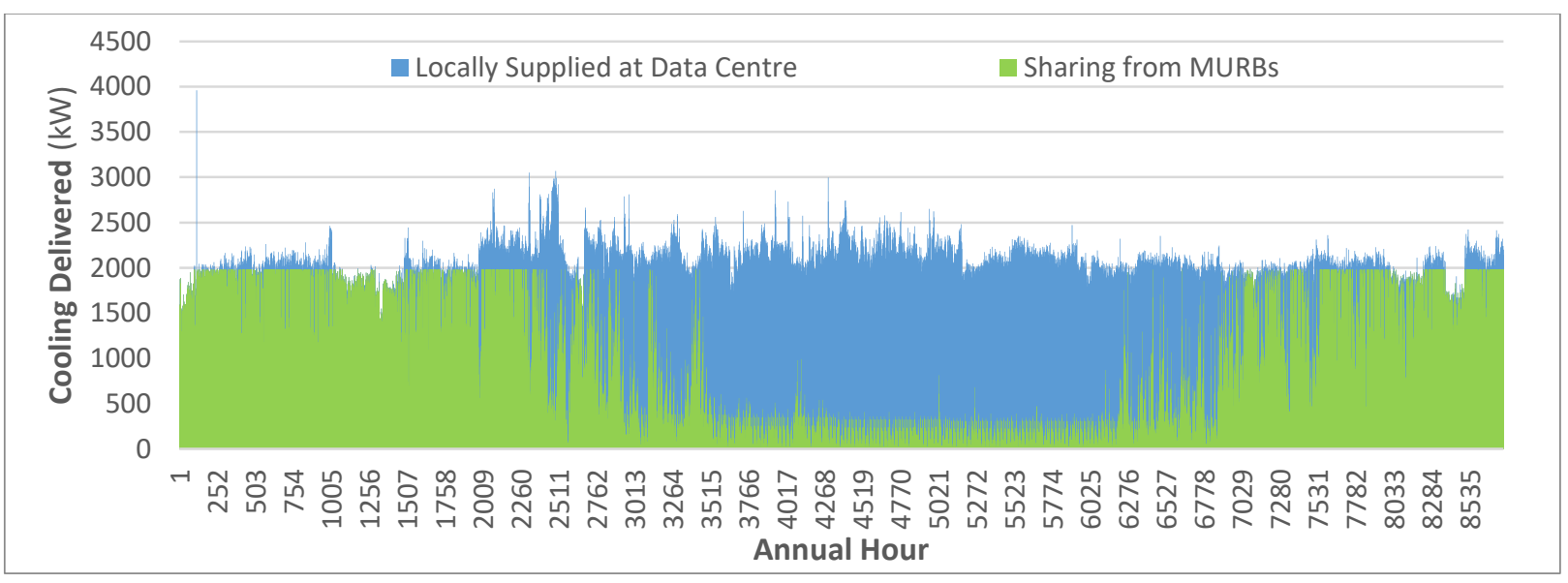

Figure 33: Data centre cooling load profile, showing loads met by energy sharing 


\subsection{Scenario 2 - One-Borefield System}

The second connection configuration uses a single borefield to provide additional low carbon heating and more efficient cooling during periods where data centre cooling and MURB heating do not coincide. Figure 34 shows that the energy sharing heat pump is only used for simultaneous heating and cooling loads, where temperatures leaving both the condenser and evaporator can be controlled because they are constant. A ground source heat pump is used in either heating or cooling mode to control the temperature leaving either the condenser or evaporator, respectively. Two heat pumps are required because one heat pump would not be able to control the temperature leaving both the condenser and the evaporator, when one is receiving varying temperatures from the borefield. The borefield thermal loading must be balanced between the amount of heat rejected and extracted annually, which is why a cooling tower is used to offset the amount of heat rejected to the borefield.

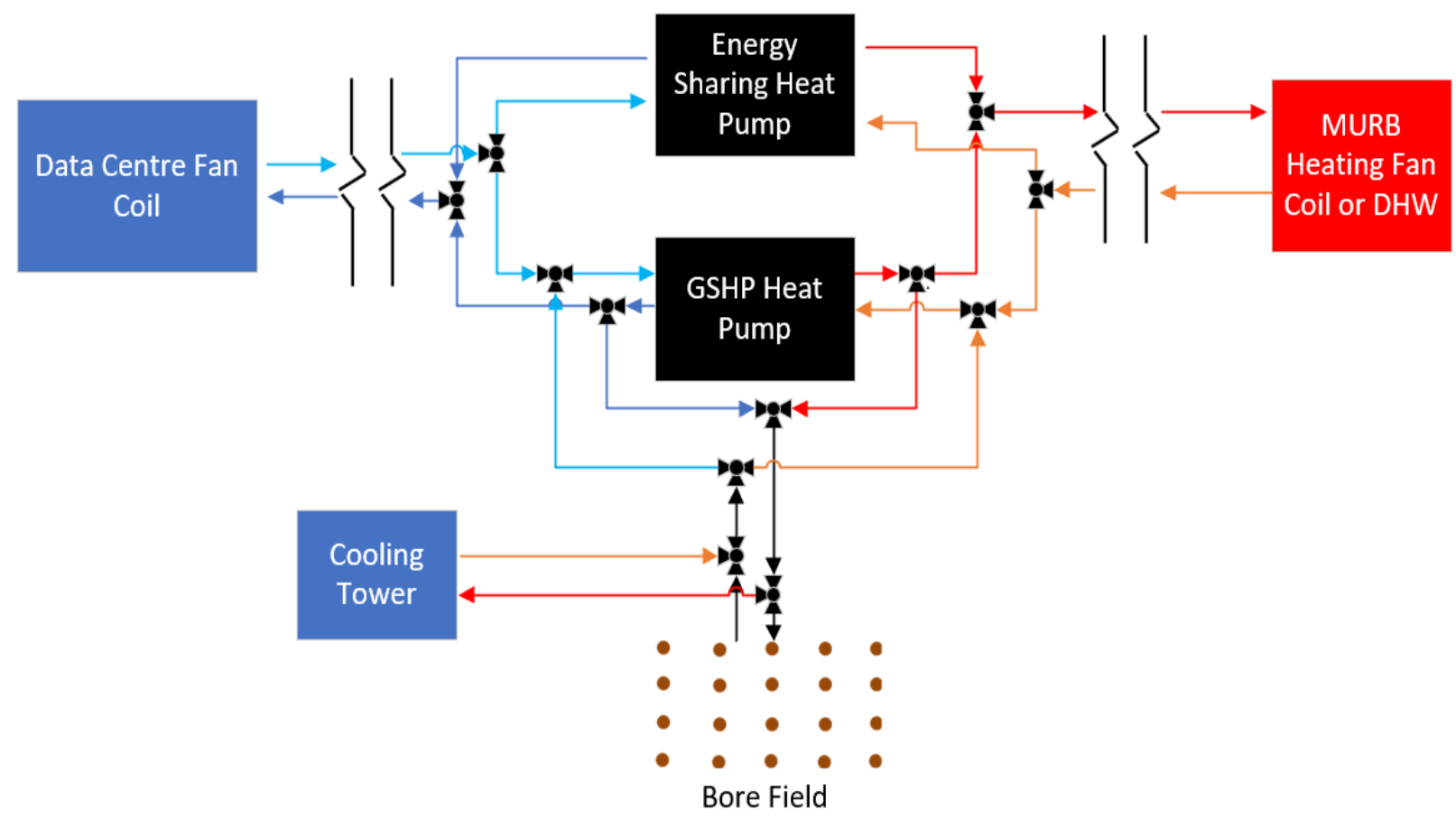

Figure 34: One-Borefield System (Scenario 2) schematic, simulated in GLD 
Geo-exchange should not provide all the remaining capacity for the MURB and the data centre because it would not be economically viable to do so. Figure 35 is an example of how the capacity provided by the CEN was determined. The point on the graph in which capacity was minimal and the amount of energy met was above $80 \%$ was chosen as the optimal portion of peaking heating to be supplied by the CEN. The optimal portions of peak for MURB heating and data centre cooling were determined to be $40 \%$ and $50 \%$ from Figure 35 and Figure 60 in the Appendix, respectively.

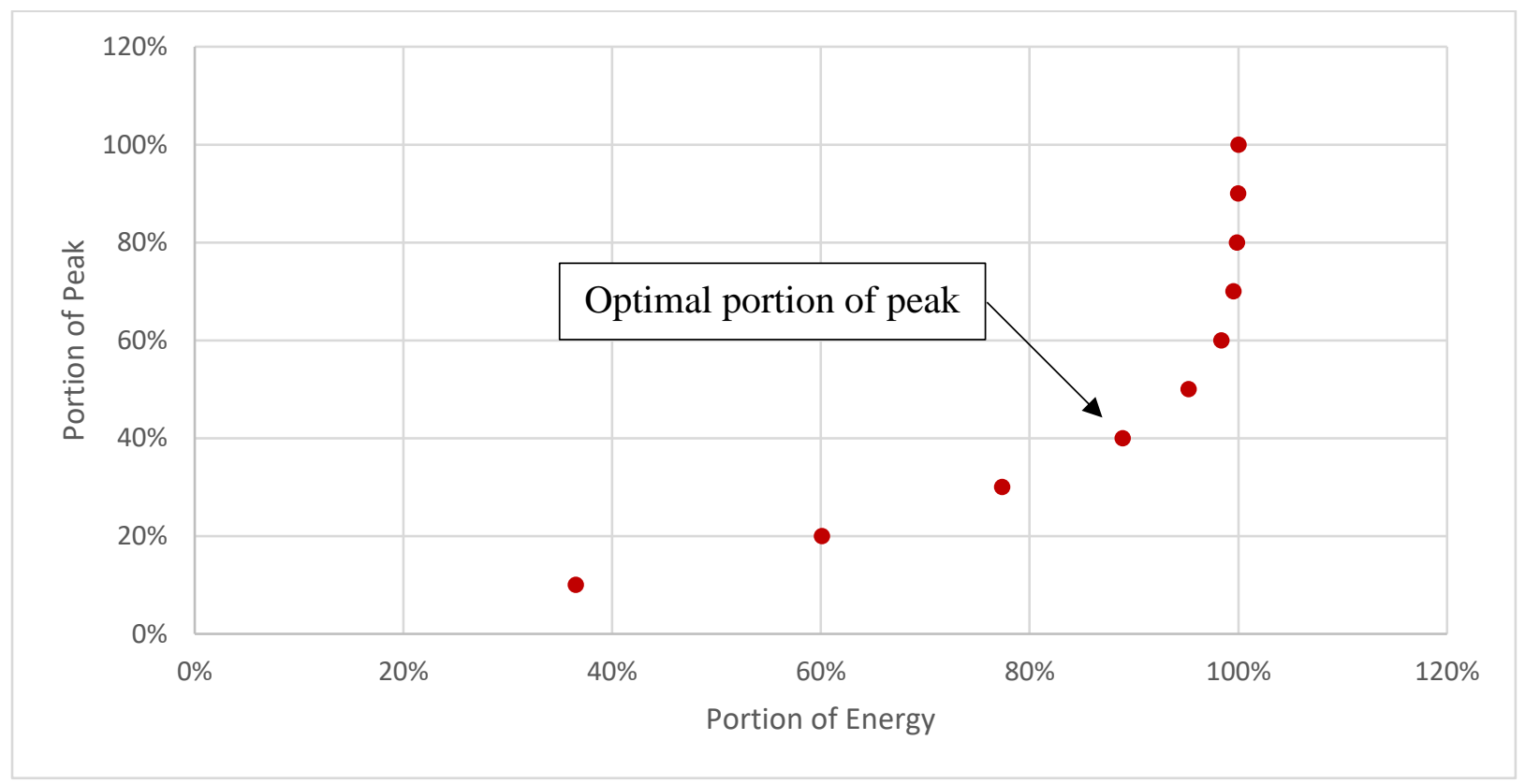

Figure 35: Optimization of energy met by the CEN for minimized peak provided by the CEN

Forty percent is a typical optimal portion of peak heating for a MURB load profile in Toronto. Figure 36 shows the results of an analysis performed by Nguyen et al. [66]. It shows the optimal portions of peak (shave factors) for several types of buildings in Toronto. Building numbers six through nine are mid- and high-rise MURBs and have shave factors between 30 and $40 \%$. 


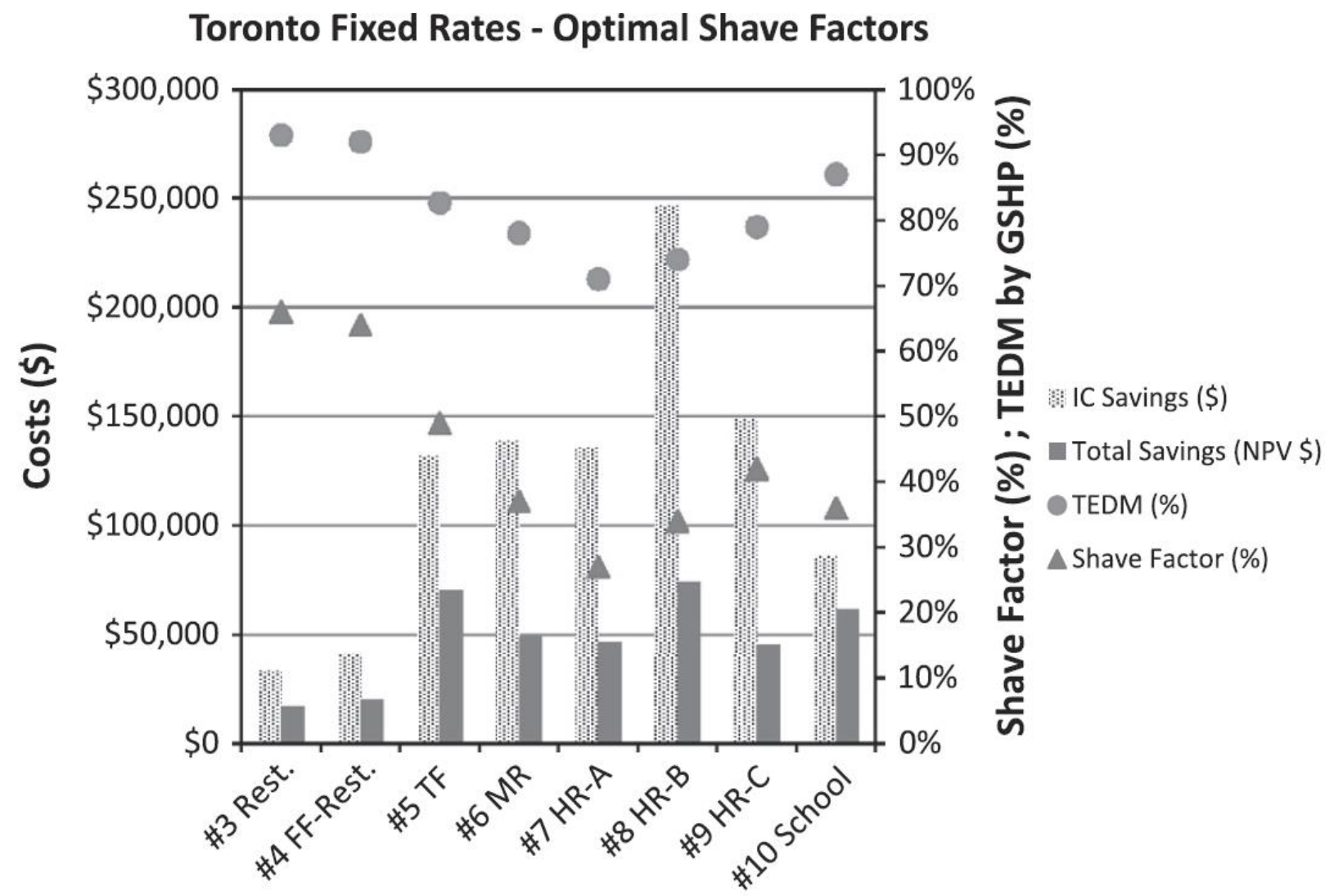

Figure 36: Results of cost lifecycle cost optimization performed by Nguyen et al. (2014), showing optimal shave factors for several building types in Toronto

Figure 37 shows how geo-exchange supplements MURB heating, so that the CEN provides $40 \%$ of heating capacity. Since the MURB can count on the CEN to consistently provide up to $40 \%$ of heating capacity, building owners could decide to remove equipment to free up space in the building, or the equipment could be left so that a higher level of reliability is achieved through increased redundancy. 


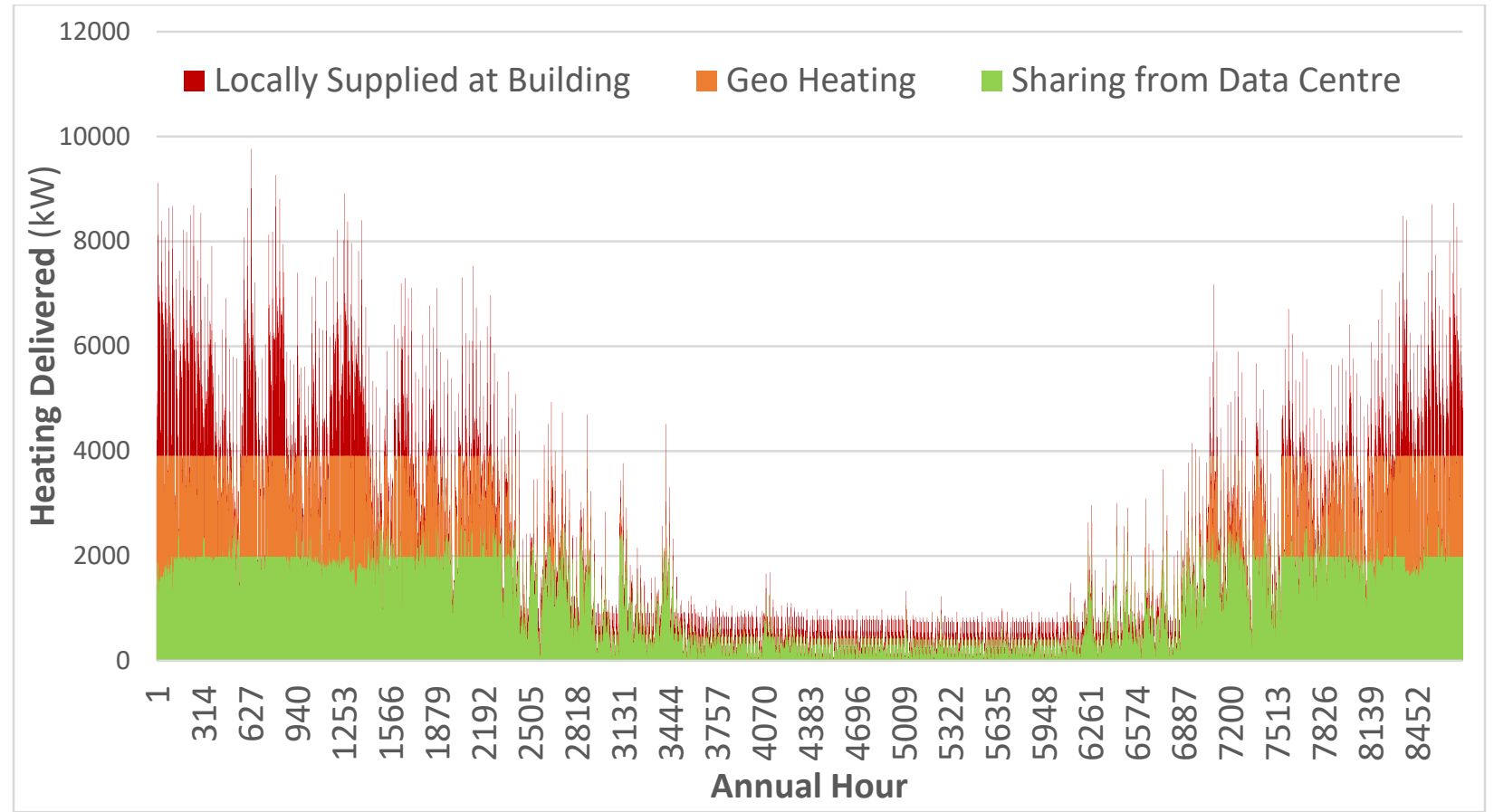

Figure 37: MURB heating load profile, showing loads met by energy sharing and geoexchange

Figure 38 shows how geo-exchange supplements data centre cooling, so that the CEN provides $50 \%$ of cooling capacity. The data centre can also remove chillers or achieve higher reliability by keeping the redundant chillers.

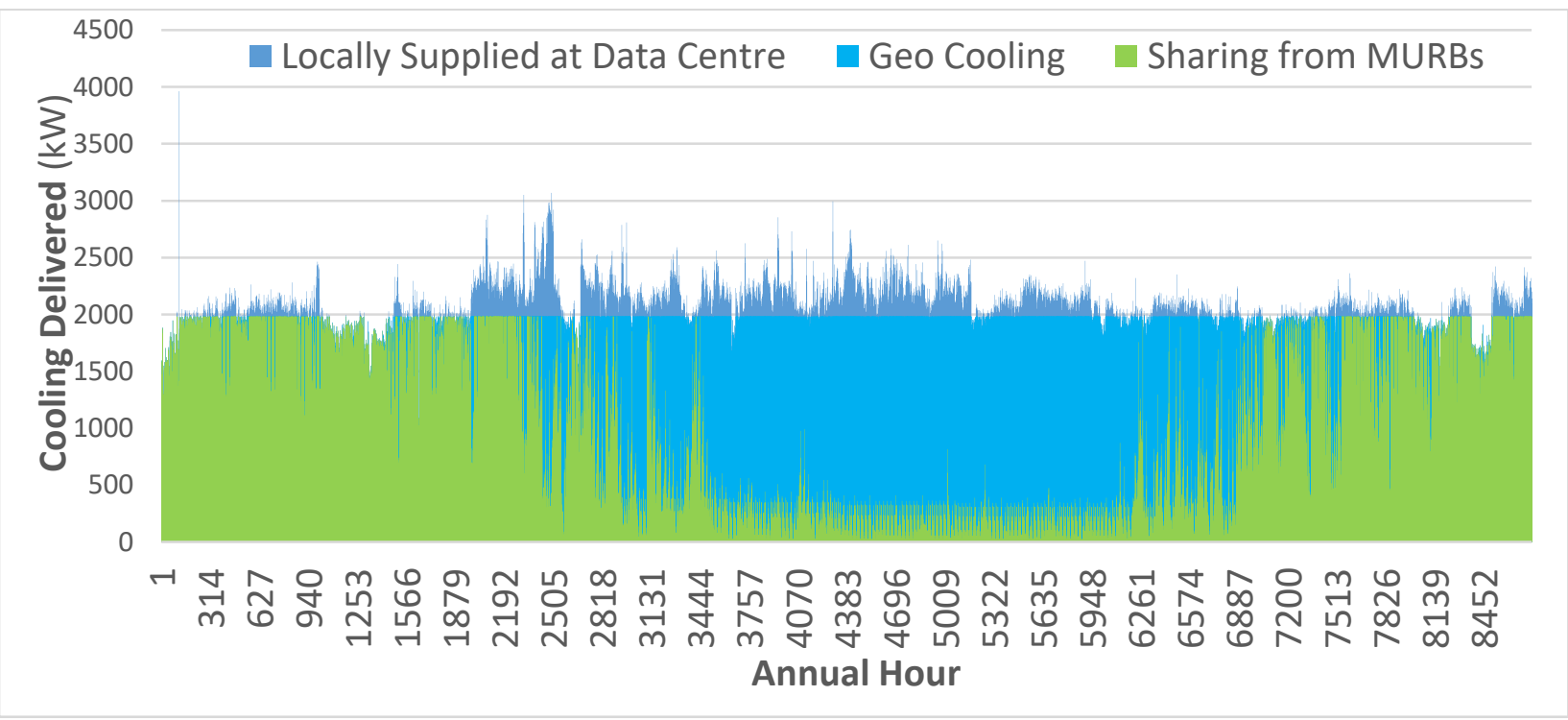

Figure 38: Data centre cooling load profile, showing loads met by energy sharing and geoexchange 
Table 5 summarizes the sources of energy and capacity provided for MURB heating and cooling and data centre cooling.

Table 5: Summary of sources of energy in the CEN

\begin{tabular}{|l|c|c|c|c|}
\hline & $\begin{array}{c}\text { MURB Heating } \\
\text { (MWh) }\end{array}$ & & $\begin{array}{c}\text { Data Centre Cooling } \\
\text { (MWh) }\end{array}$ & \\
\hline Existing Capacity & 3,125 & $18 \%$ & 809 & $4 \%$ \\
\hline Geo-exchange & 4,828 & $27 \%$ & 8,039 & $46 \%$ \\
\hline Energy Sharing & 9,782 & $55 \%$ & 8,798 & $50 \%$ \\
\hline Total & 17,735 & $100 \%$ & 17,646 & $100 \%$ \\
\hline
\end{tabular}

MURBs were not provided with cooling from the CEN, after testing the viability of doing so produced lower IRRs. There are three main reasons that including MURB cooling was less financially viable:

1. Adding MURB cooling created an overly cooling dominant environment in the borefield, which required a large portion of rejected heat to go to cooling towers which do not improve cooling efficiency compared to the existing case.

2. MURB cooling occurred at the same time as domestic hot water loads in the summer. To provide heating and cooling to the MURB at the same time would require four distribution pipes, which adds to the capital cost of the system.

3. MURB cooling requires a lower chilled water supply temperature of $7^{\circ} \mathrm{C}$ than the data centre's $10^{\circ} \mathrm{C}$ because data centres require very little latent cooling [67] [68]. Producing lower chilled water temperatures requires more energy and makes it more difficult to provide free cooling.

\subsubsection{Borefield Simulation}

GLD was used to simulate the scenario presented in Figure 34. Table 6 summarizes the input parameters that were used in the simulation [69]. The ground in Toronto is primarily shale 
with $10 \mathrm{~m}$ of overburden. All input parameters for the GLD simulation are shown in Figures 6568 in the Appendix.

Table 6: Borefield parameters inputted into GLD and TRNSYS for simulation

\begin{tabular}{|l|c|}
\hline Working Fluid & $12.9 \%$ Propylene Glycol \\
\hline Design System Flowrate & $3.0 \mathrm{GPM} / \mathrm{ton}$ \\
\hline Depth of Boreholes & $207 \mathrm{~m}$ \\
\hline Borehole Spacing & $6.1 \mathrm{~m}$ \\
\hline Ground Temperature & $10^{\circ} \mathrm{C}$ \\
\hline Ground Thermal Conductivity & $2.94 \mathrm{~W} / \mathrm{mK}$ \\
\hline Ground Thermal Diffusivity & $0.072 \mathrm{~m} / \mathrm{day}$ \\
\hline Borehole Thermal Resistance & $0.136 \mathrm{mK} / \mathrm{W}$ \\
\hline Pipe Size & $40 \mathrm{~mm}$ \\
\hline Borehole Diameter & $108 \mathrm{~mm}$ \\
\hline $\begin{array}{l}\text { Average Load Side EWT - Heating (Hot Water } \\
\text { Return) }\end{array}$ & $32^{\circ} \mathrm{C}$ \\
\hline Load Side EWT - Cooling (Chilled Water Return) & $16^{\circ} \mathrm{C}$ \\
\hline
\end{tabular}

Multiple 20-year simulations were performed to determine the minimum number of boreholes that would produce source side entering water temperatures (EWT) greater than $-1^{\circ} \mathrm{C}$ and less than $35^{\circ} \mathrm{C}$ [70]. The heat pump entering water temperature profile shown in Figure 39, produced from the simulation in GLD showed that these conditions could be met with 200 boreholes. This requires $150 \mathrm{ft}$ of borehole length per ton of peak load met. This is in line with typical vertical closed loop geo-exchange installations in Ontario at 150 to $200 \mathrm{ft}$ per ton [71]. The 20-year average ground source heat pump (GSHP) COPs under the source temperatures shown in Figure 39 were 3.5 in heating mode and 8.2 in cooling mode. To balance the borefield temperature, $50 \%$ of the cooling energy and $61 \%$ of the peak cooling load were considered to be rejected to a cooling tower. 


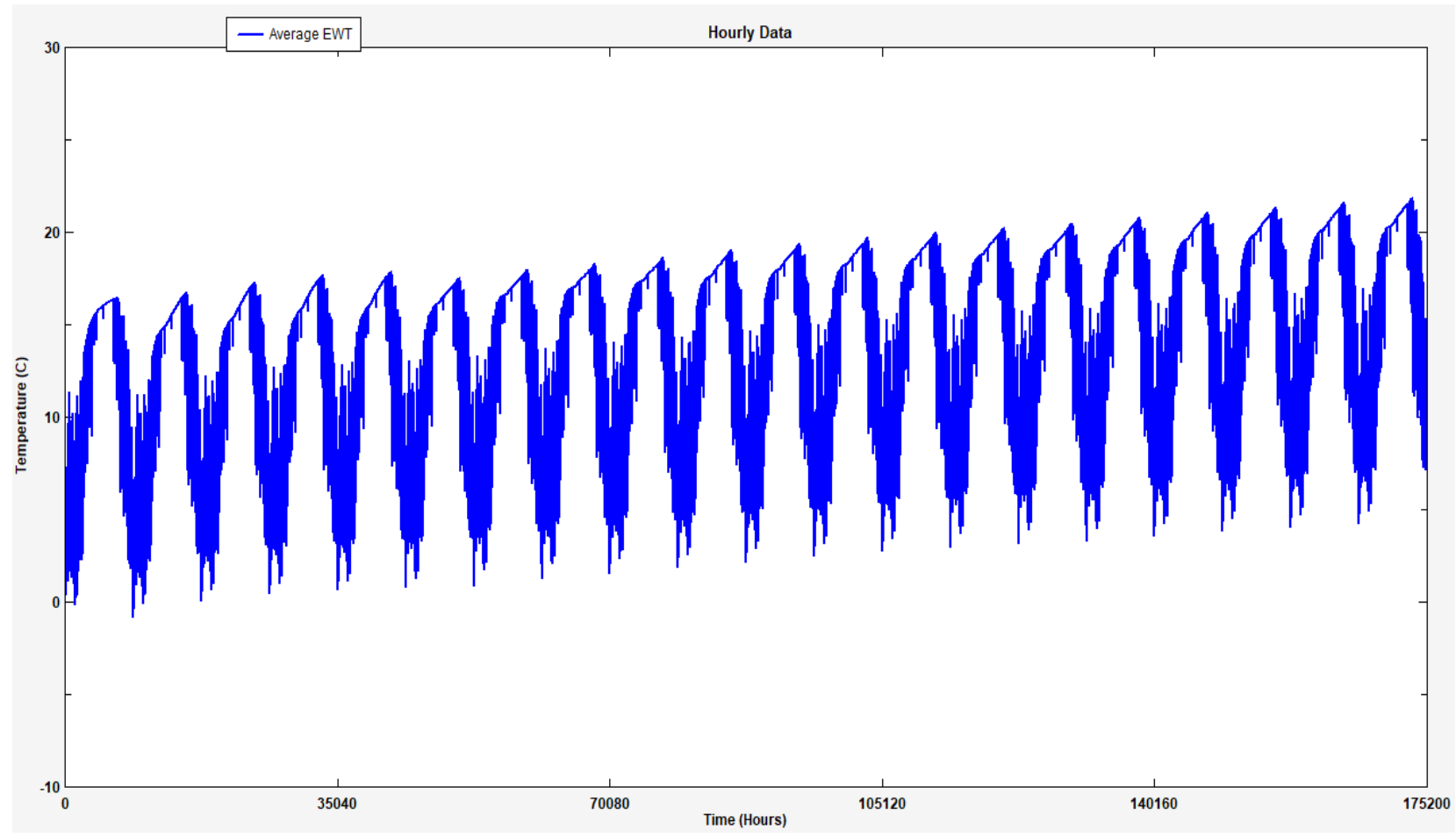

Figure 39: 20 Year hourly GLD simulation of the One-Borefield System, showing the fluid temperature leaving the borefield and entering the heat pump

\subsection{Scenario 3 - Two-Borefield System}

The third scenario is an attempt to improve ground source heat pump heating efficiency

and provide free cooling in every hour of the year, shown Figure 40 . Chilled water return at $16^{\circ} \mathrm{C}$ is passed through a "hot" borefield used for heating, reducing the fluid's temperature to approximately $13^{\circ} \mathrm{C}$, while also warming up this "hot" borefield and maintaining its energy balance. After the first "hot" borefield, the chilled water return fluid enters a second borefield which is a designated "cold" borefield. This "cold" borefield is cooled in the winter by using a dry cooler to transfer the coldness of the outdoor air to the borefield. The dry cooler circuit runs anytime the outdoor air temperature is below $10^{\circ} \mathrm{C}$ and no cooling is demanded. Finally, the chilled water is delivered to the data centre at $10^{\circ} \mathrm{C}$ or less. The TRNSYS model layout is shown in Figure 69 in the Appendix. 


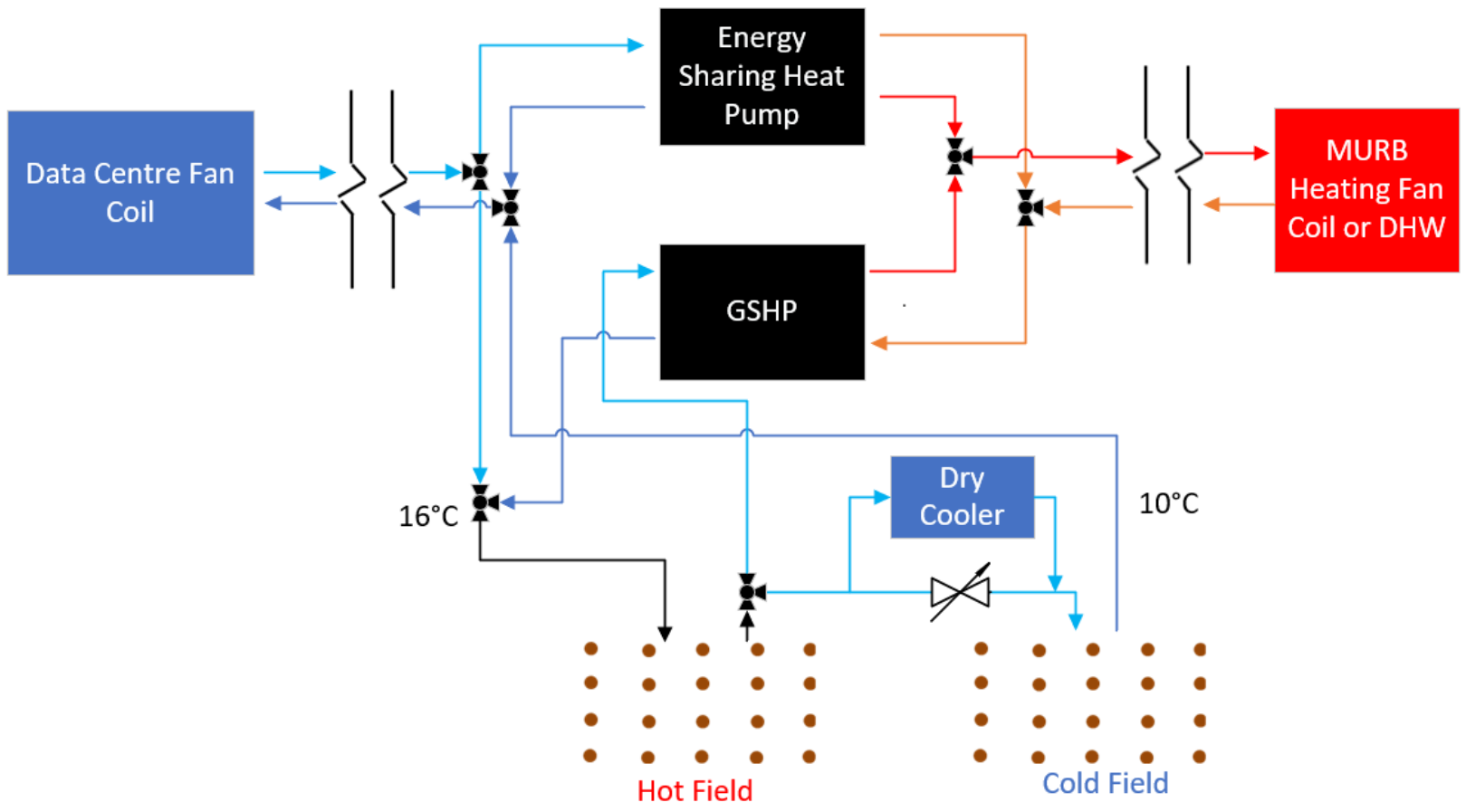

Figure 40: Two-Borefield System (Scenario 3) schematic, simulated in TRNSYS

The same borefield parameters were used in the One-Borefield System as the TwoBorefield System. The full list of inputs parameters are shown in Tables 38 to 45 in the Appendix. Figure 41 shows the 20-year source entering water temperatures in red and the average temperature in the entire "hot" borefield volume in green, outputted by TRNSYS. Two hundred and fifty boreholes were required to maintain the source entering water temperature above $-1^{\circ} \mathrm{C}$ and below $35^{\circ} \mathrm{C}$ in the "hot" borefield. It also shows that the borefield temperature is relatively balanced. The heating COP was 3.9 according to TRNSYS. This is expected because 3.9 falls in-between the heating COP of a regular borefield, in the One-Borefield System at 3.7 and the heating COP of a heat pump sourcing from $16^{\circ} \mathrm{C}$, in the Energy Sharing System at 4.3. 


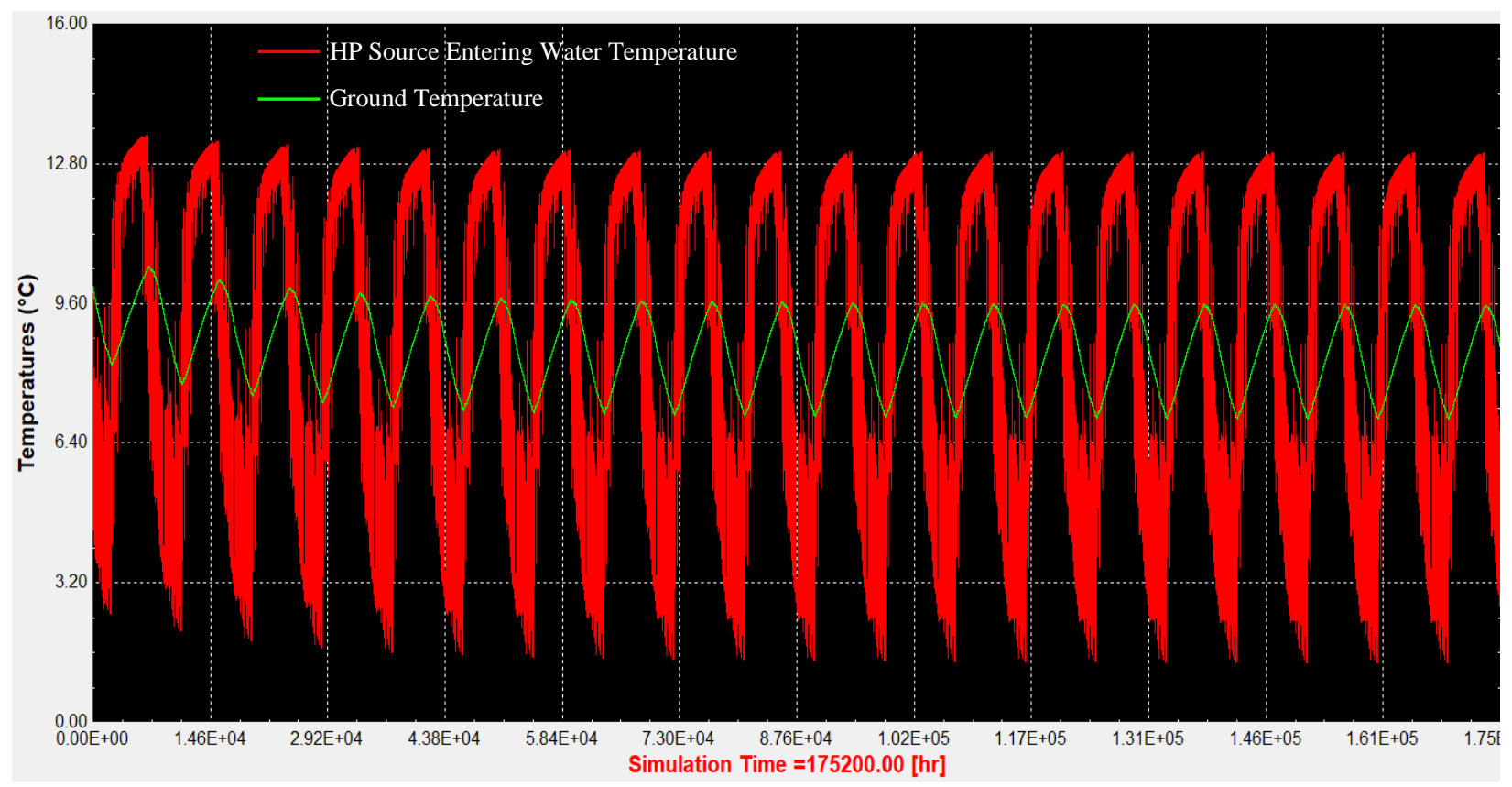

Figure 41: 20-Year hourly TRNSYS simulation of the "hot" borefield in the Two-Borefield System, showing the fluid temperature leaving the borefield and entering the heat pump in red and the average temperature in the entire "hot" borefield volume in green

Figure 42 shows the water temperature entering the borefield after being cooled by the dry cooler. Figure 42 shows that 320 boreholes were required to maintain the chilled water supply temperature, or the borefield leaving water temperature under $10^{\circ} \mathrm{C}$. There is a significant portion of time in which the borefield leaving water temperature is below freezing, which would cause freezing of the ground surrounding each borehole during these times. An uncaptured aspect of this scenario is the potential increase in thermal conductivity of the ground due to freezing. 


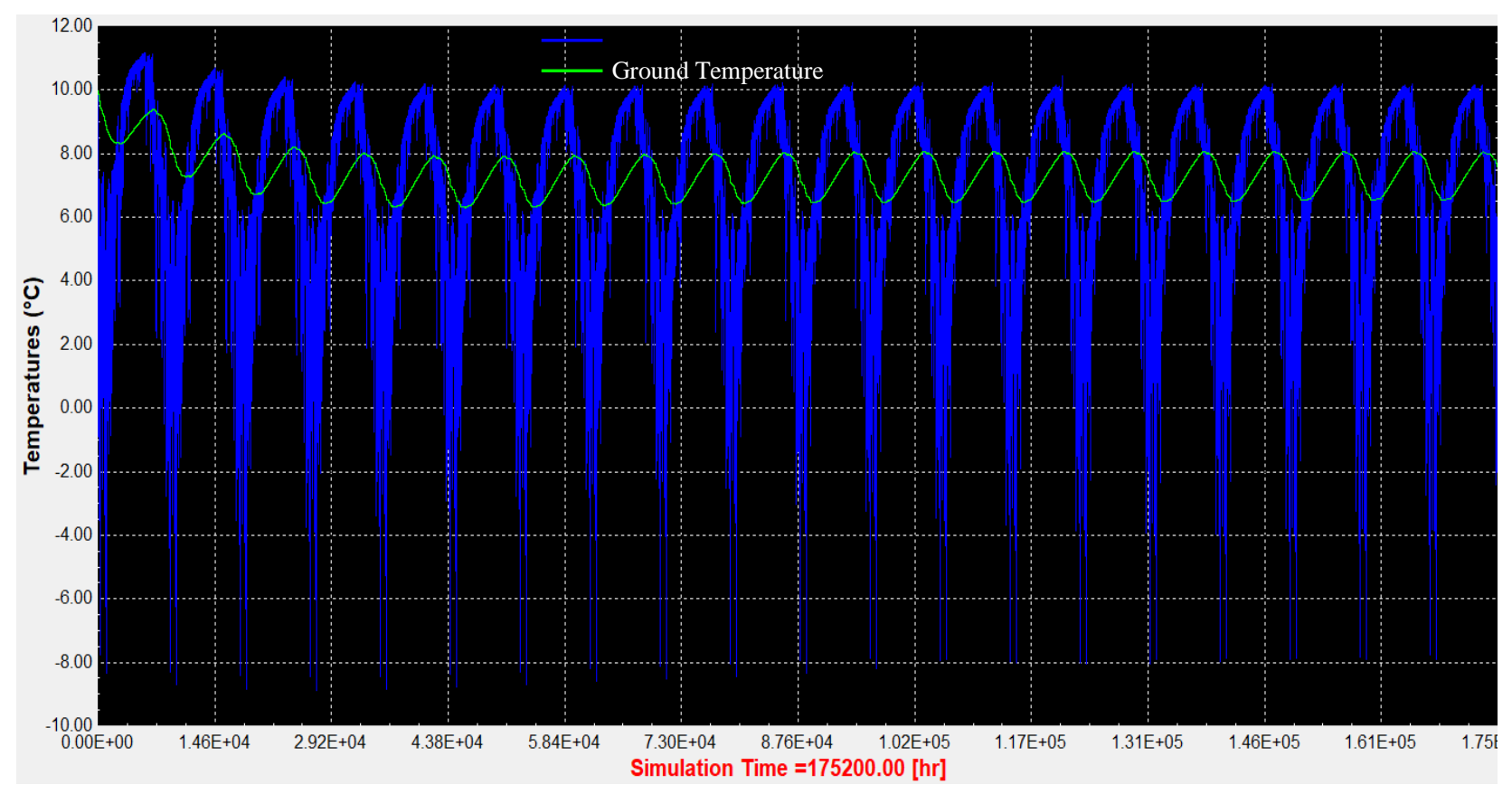

Figure 42: 20-Year hourly TRNSYS simulation of the "cold" borefield in the Two-Borefield System, showing the fluid temperature leaving the borefield and entering the data centre fan coils in blue and the average temperature in the entire "cold" borefield volume in green

The thermal storage efficiency of the cold borefield was also calculated. The dry cooler injects $4,136,000 \mathrm{kWh}$ of cooling into the "cold" field annually and the ground source heat pump injects $3,583,000 \mathrm{kWh}$ of cooling into the "hot" field annually. Comparing this to the $8,039,000 \mathrm{kWh}$ annual cooling requirement that was met, the resulting thermal storage efficiency is $104 \%$. The reason the efficiency is over $100 \%$ is that the undisturbed ground temperature is the same as the target temperature, so there is a small amount of passive cooling occurring as well.

\subsection{Financial Model}

A financial analysis was conducted to compare the three scenarios against each other and against the existing operation cost of the two building types. In this financial model heating and cooling revenue are obtained by issuing a consumption charge to the end users. The consumption charge is computed using Equation 7.

$$
\text { Consumption Charge }=\text { Annual Energy Consumption } * \frac{\text { Fuel Cost }}{\text { Existing Efficiency }}
$$


The variable costs for the utility provider are computed using Equation 8. Variable costs for cooling can include electricity, water and chemicals. Variable costs for heating can include electricity and natural gas.

$$
\text { Variable Cost }=\text { Annual Energy Consumption } * \frac{\text { Fuel Cost }}{\text { Proposed Efficiency }}
$$

The heating and cooling gross profit are computed using Equation 9.

$$
\text { Gross Profit }=\text { Consumption Charge }- \text { Variable Costs }
$$

The net cash flow for the utility provider is calculated for each year using Equation 10.

$$
\text { Net Cash Flow = Total Gross Profit - Capital Expenditures }
$$

The IRR is computed using Excel's IRR function, which uses Equation 11 to determine the IRR, where CF is the net cashflow in each year. The IRR was calculated over a 30-year period.

$$
0=C F_{0}+\frac{C F_{1}}{(1+I R R)^{1}}+\frac{C F_{2}}{(1+I R R)^{2}}+\cdots+\frac{C F_{30}}{(1+I R R)^{30}}
$$

The after-tax IRR is also calculated using Equation 11 but uses after tax cash flow for the CF variable. The after-tax cash flow is calculated using Equation 12, with Equations 13 and 14 nested inside it.

$$
\begin{gathered}
\text { After Tax Cash Flow }=\text { Pre Tax Cash Flow }- \text { Taxes Payable } \\
\text { Taxes Payable }=(\text { Book Value of Asset } * \text { Depreciation Rate }) * \text { Tax Rate }
\end{gathered}
$$

The book value of the asset in a given year is calculated using Equation 14, where $\mathrm{n}$ is the year in the contract.

$$
B V_{n}=B V_{n-1}-\left(B V_{n-1} * \text { Depreciation Rate }\right)
$$

The after-tax IRR is used as the final basis for comparison between scenarios and for determining if a project can go forward.

The financial model assumes the MURBs would be willing to pay an equal rate to the community energy provider for heating and cooling because of the significant emissions that 
would be reduced. The natural gas rate for MURBs was determined from one year of bills from a condominium building in Toronto, ending in March 2017. The average annual natural gas rate was calculated to be $\$ 0.31 / \mathrm{m}^{3}$. MURBs were assumed to have an existing boiler efficiency of $78 \%$.

Data centre cooling efficiency and marginal electricity cost are shown in Table 7. These values were obtained from an employee of a data centre in Toronto. The financial model assumes a data centre would only participate in a CEN if they received a $25 \%$ decrease in operational cost. This is because data centres will be conservative with any changes to their existing operations. Therefore, in the financial model the existing total cooling COP (including the cooling tower) is 5.48 a $25 \%$ increase in efficiency compared to the total cooling COP of 4.39, calculated from Table 7.

Table 7: Existing cooling operation parameters for data centre

\begin{tabular}{|l|c|}
\hline Data Centre Existing Operational Cost & \\
\hline Chiller Efficiency & $6.2 \mathrm{COP}(0.566 \mathrm{~kW} / \mathrm{ton})$ \\
\hline Cooling Tower Efficiency & $17.5 \mathrm{COP}(0.2 \mathrm{~kW} / \mathrm{ton})$ \\
\hline Water Cost & $\$ 3.45 / \mathrm{m}^{3}(\$ 0.008 /$ Tonh $)$ \\
\hline Cooling Tower Chemical Cost & $\$ 0.001 /$ Tonh \\
\hline Electricity Cost & $\$ 0.15 / \mathrm{kWh}$ \\
\hline
\end{tabular}

Table 8 shows the assumptions for utility rate escalations in the financial model.

Table 8: Utility escalators used in financial model [72]

\begin{tabular}{|l|c|}
\hline Utility Escalators & \\
\hline Natural Gas Escalation Rate & $2.5 \%$ \\
\hline Electricity Escalation Rate Until 2027 & $4 \%$ \\
\hline Electricity Escalation Rate after 2027 & $2 \%$ \\
\hline Water Escalation Rate & $2 \%$ \\
\hline Cooling Tower Chemicals Escalation Rate & $2 \%$ \\
\hline Carbon Tax on Natural Gas 2018 & $\$ 20 /$ tonne \\
\hline Carbon Tax Escalation Rate & $7 \%$ \\
\hline
\end{tabular}

The following Table 9, shows the financing cash flow assumptions used in the model. 
Table 9: Financing cashflow parameters used in financial model [72]

\begin{tabular}{|l|c|}
\hline Financing Cashflow & \\
\hline Term & 30 years \\
\hline Tax Rate & $26.5 \%$ \\
\hline Depreciation Rate & $9.5 \%$ \\
\hline
\end{tabular}

\subsubsection{Scenario 1 - Energy Sharing System}

Table 10 summarizes the capital costs required to establish a community energy system for energy sharing. An eight-inch supply and return pipe is required to deliver heating to the MURBs and cooling to the data centre. The pipe size was determined in a program called System Syzer [73], which calculates peak flow rates, using Equation 2 when given the differential temperature of the system and its peak load. The program then references ASHRAE 90.1-2010 maximum pipe velocities for given sizes and materials to check if the required flow rate is appropriate for the selected pipe size [74]. All the equipment costs were obtained from Enwave's cost data and include installation [72].

Table 10: Energy Sharing System (Scenario 1) capital costs used in financial model [72]

\begin{tabular}{|l|c|c|c|c|}
\hline \multicolumn{1}{|c|}{ Description } & Quantity & $\begin{array}{c}\text { Unit Rate } \\
(\$ / \text { unit })\end{array}$ & Unit & Total $(\$)$ \\
\hline To Res HW 2 x 8" Steel Pipe & 400 & 1,800 & $\mathrm{~m}$ & 720,000 \\
\hline $\begin{array}{l}\text { To Data Centre CHW 2 x 8" } \\
\text { HDPE Pipe }\end{array}$ & 100 & 1,800 & $\mathrm{~m}$ & 180,000 \\
\hline Heat Pump w/Install & 563 & 500 & tons & 281,334 \\
\hline District HW Pump & 1484 & 20 & GPM & 29,680 \\
\hline District CHW to Data Centre & 1227 & 20 & GPM & 24,540 \\
\hline Res HW HX & 8862 & 2.0 & MBH & 17,724 \\
\hline Data Centre CHW HX & 563 & 90 & ton & 50,640 \\
\hline Residential Building Retrofit Cost & 5 & 200,000 & Bldgs & $1,000,000$ \\
\hline Data Centre Connection Cost & 1 & 200,000 & Bldgs & 200,000 \\
\hline $\begin{array}{l}\text { Heat Pump Plant Building, Slab } \\
\text { on Grade, with Foundations }\end{array}$ & 1000 & 160 & $\mathrm{ft}^{2}$ & 160,000 \\
\hline $\begin{array}{l}\text { Valve Automation, Controls and } \\
\text { Instrumentation, Electrical }\end{array}$ & & & & 364,309 \\
\hline
\end{tabular}

$\mathbf{\$ 3 , 0 1 0 , 2 2 8}$ 
The MURB retrofit cost is an estimate based on several installation quotes, given to Enwave from contractors on similar buildings. Since mechanical rooms are typically on the roof of a building, a new set of pipes would be required to deliver energy to the plant and have it interface with existing equipment before being distributed to residents. Garbage chute rooms on each floor can be used to install new four-inch pipes that travel straight up to the mechanical room. Other minor work would include tying in the new pipe to the distribution system with controls to regulate flow and temperature at the heat exchanger, separating the building distribution system from the CEN. Make-up air (MAU) units in a MURB are typically direct natural gas fired. Also included in the retrofit cost is provisions for installing a double row of hydronic coils in the MAU, so that it can be fed heating water from the CEN.

Minor work would also need to be carried out to connect the data centre. A heat exchanger would need to be installed at the data centre, then a new set of pipes would need to interface with the chilled water supply and return pipes at the data centre chiller plant to supplement.

A 1000 square foot structure for a heat pump plant was included in the capital costs. The cost to build the on-grade structure was priced at $\$ 160$ per square foot, based on Enwave's past projects [72]. Finally, $13 \%$ of the total capital cost was allocated for new electrical connections, as well as valve automation and controls and instrumentation.

The capital costs spent by the community energy provider are meant to be recovered through gross profit from efficient operation over a 30-year period. The operational costs for the Energy Sharing System are shown in Table 11. 


\section{Table 11: Energy Sharing System operational parameters}

\begin{tabular}{|l|c|}
\hline \multicolumn{2}{|c|}{ Provider Operational Costs } \\
\hline Heat Pump Heating COP & 4.3 \\
\hline Heating Distribution Pump Efficiency & $0.0057 \mathrm{~kW} / \mathrm{ton}$ \\
\hline Cooling Distribution Pump Efficiency & $0.0012 \mathrm{~kW} / \mathrm{ton}$ \\
\hline Electricity Cost & $\$ 0.15 / \mathrm{kWh}[75]$ \\
\hline
\end{tabular}

The pump power requirements in $\mathrm{kW}$ were calculated using Equation 15. The flow rates in GPM were calculated using Equation 2, given system differential temperature and peak load. System Syzer was used to calculate H (head), the pressure differential in equivalent feet of water column, given the pumping distance and pipe material. The pump motor efficiency was assumed to be $77 \%$, with a $97 \%$ electrical efficiency, resulting in $75 \%$ for $\eta$. The 0.746 factor is used to convert from horsepower to $\mathrm{kW}$. After determining the pump power requirement, Pump, Equation 16 was used to calculate the pumping efficiency used in the financial model, where QPeak is maximum thermal load on an 8760 load profile.

$$
\begin{gathered}
P_{\text {Pump }}=\frac{G P M * H}{3960 * \eta} * 0.746 \\
\text { Pump }_{\text {eff }}=\frac{P_{\text {Pump }}}{Q_{\text {Peak }}}
\end{gathered}
$$

The 30-year average cooling gross profit margin, where gross profit margin is defined in Equation 17 for the Energy Sharing Scenario was 98\%. The margin is extremely high because only pumping energy was associated to cooling. The 30 -year average heating gross profit margin was $19.6 \%$. Since the price of natural gas is several times cheaper than electricity, the 4.3 COP was comparable to existing heating operation costs, but slightly better.

$$
\text { Gross Profit Margin }=\frac{\text { Consumption Charges }}{\text { Variable Costs }}
$$




\subsubsection{Scenario 2 - One-Borefield System}

The One- and Two-Borefield Systems only provide a portion of heating and cooling capacity to respective buildings, however at the end of the existing equipment life, a portion of the equipment would not need to be replaced because the buildings can rely on the CEN for capacity. A capacity charge can be used to account for this value. A capacity charge was not considered in Scenario 1 because the source of heating or cooling for the CEN is dependent on the demand of the other building type, and cannot be $100 \%$ reliable. Table 12 summarizes the replacement costs of relevant equipment in MURBs, which were used to calculate the capacity charge. This information was obtained from a condo reserve account in Toronto and indicates the expected lifetime of equipment [76].

Table 12: Heating equipment replacement costs for MURBs

\begin{tabular}{|l|c|c|}
\hline & $\begin{array}{c}\text { Capital Cost } \\
(\$ / M B H ~ 2014)\end{array}$ & $\begin{array}{c}\text { Life Span } \\
\text { (years) }\end{array}$ \\
\hline Space Heating Boiler & 29 & 25 \\
\hline Domestic Hot Water Boiler & 29 & 25 \\
\hline
\end{tabular}

It is assumed that MURBs will go through one replacement of boilers over the span of the 30 -year contract. The annual capacity was then calculated to be the cost of the equipment in 2020 (the start of the contract) divided by 30 . The annual capacity charge is then $\$ 2.12$ per MBH of capacity insured by the CEN in 2020 . This charge would be escalated by the consumer price index (CPI) throughout the 30-year contract.

The data centre would also pay a capacity charge for not having to replace a portion of their chiller and cooling tower system. The data centre is assumed to replace chillers and cooling towers once over the span of the 30-year contract. Since a typical installed cost for a chiller plant, including the cooling tower, is $\$ 1500 /$ ton, the annual capacity charge for the data centre would be 
$\$ 1500 /$ ton divided by 30 . This results in a charge of $\$ 50$ per ton of capacity insured by the CEN in 2020 and escalated by CPI throughout the 30-year contract.

The One-Borefield case uses the same existing operational costs for the MURBs and the data centre as Scenario 1. Table 13 summarizes the capital costs associated to developing a community energy system that includes a borefield. The cost of purchasing land for a borefield was not considered. It was assumed that a partnership with the local municipality could be reached which would allow drilling in a municipal park as long as it is restored to its original state once drilling is complete.

Table 13: One-Borefield System (Scenario 2) capital costs used in financial model [72]

\begin{tabular}{|l|c|c|c|c|}
\hline \multicolumn{1}{|c|}{ Description } & Quantity & $\begin{array}{c}\text { Unit Rate } \\
\text { (\$/unit) }\end{array}$ & Unit & Total $\mathbf{( \$ )}$ \\
\hline To MURBs HW 2 x 8" Steel Pipe & 400 & 1,800 & $\mathrm{~m}$ & 720,000 \\
\hline To Data Centre CHW 2 x 8" HDPE Pipe & 100 & 1,800 & $\mathrm{~m}$ & 180,000 \\
\hline Heat Pump w/Install & 1125 & 500 & ton & 562,668 \\
\hline Cooling Tower w/Install & 340 & 200 & ton & 68,000 \\
\hline District HW Pump & 2059 & 20 & GPM & 41,180 \\
\hline District CHW to Data Centre & 1227 & 20 & GPM & 24,540 \\
\hline MURB HW HX & 13321 & 2.0 & MBH & 26,642 \\
\hline Data Centre CHW HX & 563 & 90 & ton & 50,640 \\
\hline Residential Building Retrofit Cost & 5 & 200,000 & Bldg & $1,000,000$ \\
\hline Data Centre Connection Cost & 1 & 200,000 & Bldg & 200,000 \\
\hline $\begin{array}{l}\text { Heat Pump Plant Building, Slab on } \\
\text { Grade, with Foundations }\end{array}$ & 1000 & 160 & $\mathrm{ft} \mathrm{t}^{2}$ & 160,000 \\
\hline $\begin{array}{l}\text { Valve Automation, Controls and } \\
\text { Instrumentation, Electrical }\end{array}$ & & & & 394,377 \\
\hline Borefield & 200 & 9900 & hole & $1,980,000$ \\
\hline
\end{tabular}

The heat pump capacity needed to be increased from Scenario 1 because separate heat pumps were required to be able to provide energy sharing and energy from geo-exchange at the same time. The cost of the borefield which includes everything from drilling to installation of the manifold was obtained from a local Ontario driller, Geo Source [45]. 
The operational costs for the One-Borefield System are shown in Table 14. The system COP for heating and cooling was calculated using Equation 18, where the total annual heating or cooling load met by the CEN is $\mathrm{Q}_{\mathrm{L}}$ and the total electricity consumed by the energy sharing heat pump, the geo-exchange heat pump, the cooling tower, the distribution pumps and the geoexchange circulation pumps is shown as $\mathrm{W}_{\text {tot. }}$. The system COP was calculated to be 3.1 for heating and 11.7 for cooling.

$$
C O P_{\text {sys }}=\frac{Q_{L}}{W_{\text {tot }}}
$$

Table 14: One-Borefield System operational parameters

\begin{tabular}{|l|c|}
\hline \multicolumn{2}{|c|}{ Provider Operational Costs } \\
\hline Energy Sharing Heating COP & 4.3 \\
\hline Heating Distribution Pump Efficiency & $0.0057 \mathrm{~kW} /$ ton \\
\hline Cooling Distribution Pump Efficiency & $0.0012 \mathrm{~kW} /$ ton \\
\hline Geo-exchange Pump Efficiency in Heating Mode & $0.0171 \mathrm{~kW} /$ ton \\
\hline Geo-exchange Pump Efficiency in Cooling Mode & $0.0344 \mathrm{~kW} /$ ton \\
\hline Geo-exchange Heating COP & 3.5 \\
\hline Geo-exchange Cooling COP & 8.2 \\
\hline Chiller COP when Connected to Cooling Tower & $6.2 \mathrm{COP}(0.56 \mathrm{~kW} /$ ton $)$ \\
\hline Cooling Tower COP & $17.5 \mathrm{COP}(0.2 \mathrm{~kW} /$ ton $)$ \\
\hline Electricity Cost & $\$ 0.15 / \mathrm{kWh}[75]$ \\
\hline
\end{tabular}

The cooling gross profit margin was $57 \%$ in this scenario, where gross profit margin is defined in Equation 19 for the One-and Two-Borefield Systems. This is largely due to the favorable geo-exchange COP, which kept the system COP high. The heating gross profit margin was still relatively high at $17 \%$, considering the lower $3.5 \mathrm{COP}$. This is because this scenario received capacity charges, which feed into the gross profit margin equation, Equation 19.

$$
\text { Gross Profit Margin }=\frac{\text { Consumption Charges }+ \text { Capacity Charges }}{\text { Variable Costs }}
$$




\subsubsection{Scenario 3 - Two-Borefield System}

The Two-Borefield System uses the same capacity charges as the One-Borefield System and the same existing operational costs as both Scenario 1 and 2. Table 15 summarizes the capital costs associated to developing a community energy system that includes two borefields.

Table 15: Two-Borefield System (Scenario 3) capital costs used in financial model

\begin{tabular}{|l|c|c|c|c|}
\hline \multicolumn{1}{|c|}{ Description } & Quantity & $\begin{array}{c}\text { Unit Rate } \\
(\$ / \text { unit })\end{array}$ & Unit & Total $(\$)$ \\
\hline To MURB HW 2 x 8" Steel Pipe & 400 & 1,800 & $\mathrm{~m}$ & 720,000 \\
\hline $\begin{array}{l}\text { To Data Centre CHW 2 x 8" HDPE } \\
\text { Pipe }\end{array}$ & 100 & 1,800 & $\mathrm{~m}$ & 180,000 \\
\hline Heat Pump w/Install & 1125 & 500 & ton & 562,668 \\
\hline Dry Cooler w/ Install & 1000 & 150 & ton & 150,000 \\
\hline District HW Pump & 2059 & 20 & GPM & 41,180 \\
\hline District CHW to Data Centre & 1227 & 20 & GPM & 24,540 \\
\hline MURB HW HX & 13321 & 2.0 & MBH & 26,642 \\
\hline Data Centre CHW HX & 563 & 90 & ton & 50,640 \\
\hline Residential Building Retrofit Cost & 5 & 200,000 & Bldg & $1,000,000$ \\
\hline Data Centre Connection Cost & 1 & 200,000 & Bldg & 200,000 \\
\hline $\begin{array}{l}\text { Heat Pump Plant Building, Slab on } \\
\text { Grade, with Foundations }\end{array}$ & 1000 & 160 & $\mathrm{ft}^{2}$ & 160,000 \\
\hline $\begin{array}{l}\text { Valve Automation, Controls and } \\
\text { Instrumentation, Electrical }\end{array}$ & & & & 394,377 \\
\hline Borefield & 570 & 9900 & hole & $5,643,000$ \\
\hline
\end{tabular}

The only difference from the One-Borefield System scenario is that a dry cooler is used instead of a cooling tower and the size is larger because the goal is to overcool the ground. The Two-Borefield System scenario requires 370 extra boreholes total.

The operational costs for the Two-Borefield System are shown in Table 16. The system COP for heating and cooling was calculated using Equation 18, this time considering the total electricity consumed by the energy sharing heat pump, the geo-exchange heat pump in heating mode, the dry cooler, the distribution pumps, geo-exchange circulation pumps and the dry cooler circulation pumps as $\mathrm{W}_{\text {tot }}$. The system COP was calculated to be 4.1 for heating and 40 for cooling. 
Table 16: Two-Borefield System operational parameters

\begin{tabular}{|l|c|}
\hline \multicolumn{2}{|c|}{ Provider Operational Costs } \\
\hline Energy Sharing Heating COP & 4.3 \\
\hline Heating Distribution Pump Efficiency & $0.0057 \mathrm{~kW} /$ ton \\
\hline Cooling Distribution Pump Efficiency & $0.0012 \mathrm{~kW} /$ ton \\
\hline Geo-exchange Pump Efficiency in Heating Mode & $0.0171 \mathrm{~kW} / \mathrm{ton}$ \\
\hline Geo-exchange Pump Efficiency in Cooling Mode & $0.0014 \mathrm{~kW} /$ ton \\
\hline Geo-exchange Heat Pump COP in Heating Mode & 3.9 \\
\hline Dry Cooler COP & $20 \mathrm{COP}(0.17 \mathrm{~kW} / \mathrm{ton})$ \\
\hline Dry Cooler Circulation Pump Efficiency & $0.0046 \mathrm{~kW} /$ ton \\
\hline Electricity Cost & $\$ 0.15 / \mathrm{kWh}[75]$ \\
\hline
\end{tabular}

The cooling gross profit margin was $87 \%$ in this scenario because of the high 20.0 dry cooler $\mathrm{COP}$ and the fact that no electricity was required from the ground source heat pump. The heating gross profit margin was higher than that of the Energy Sharing System, at 19.9\%. This is because of the favourable $3.9 \mathrm{COP}$ and the capacity charges which were received, which feed into the gross profit margin equation, Equation 19.

\subsection{Comparison and Discussion}

The final after tax IRRs for each scenario are shown in Table 17. Before tax cash flows for all three scenarios are shown in the Appendix in Figures 61 to 63. The Energy Sharing System was most profitable, with an 11.9\% 30-year, after tax IRR. There are several reasons for this. First, energy sharing is always the most efficient method of delivering heating and cooling because the grade of the heat source from the data centre is not reduced by storing it in a borefield, which provides the highest possible COP of 4.3 for the given temperatures. Second, the capital cost of the system was the lowest because a borefield was not incorporated. This solution would financially improve with increased scale as well because $75 \%$ of the capital costs are fixed. 
Table 17: Comparison of financial model results for each scenario

\begin{tabular}{|l|c|c|}
\hline \multicolumn{1}{|c|}{ Scenario } & $\begin{array}{c}\text { 30-year, After Tax IRR } \\
\text { Before Funding }\end{array}$ & $\begin{array}{c}\text { Funding Required as \% of } \\
\text { Capital Cost to Meet 8\% IRR } \\
\text { Threshold }\end{array}$ \\
\hline Energy Sharing & $11.9 \%$ & $0 \%$ \\
\hline One-Borefield & $7.8 \%$ & $3 \%$ \\
\hline Two-Borefield & $6.6 \%$ & $15 \%$ \\
\hline
\end{tabular}

The One-Borefield System (Scenario 2) could only be more profitable than the Energy Sharing System (Scenario 1) if the incremental cost from installing the borefield was very small, since gross profit is significantly lower.

In the Two-Borefield System (Scenario 3) we can clearly see that the chilled water return temperature is reduced once it enters the hot borefield, which means the waste heat is not taken full advantage of; however, this contributes to cooling before the cold borefield. The cooling gross profit margin of the Two-Borefield System is nearly as high as the Energy Sharing System, with the difference being from the electricity required for the dry cooler. Heating gross profit was also high, at $19.9 \%$. Despite the high gross profit, the number of boreholes required to accommodate full free cooling is too large to justify without a small amount of funding.

\subsection{Emissions Analysis}

An emissions analysis was conducted to give context to the benefits of the CEN. First, the existing emissions of the MURBs and the data centre were calculated, using an electricity emissions factor of $43 \mathrm{~g} \mathrm{CO}_{2} \mathrm{e} / \mathrm{kWh}$ [77] and a natural gas emissions factor of $185 \mathrm{~g} \mathrm{CO}_{2} \mathrm{e} / \mathrm{kWh}$ [77]. Table 18 summarizes the emssions analysis.

$$
\text { Existing Total Emissions }=\frac{17,735,000 \mathrm{kWh}}{78 \%} * 185 \frac{\mathrm{g} \mathrm{CO2e}}{\mathrm{kWh}} * \frac{1 \text { tonne }}{1,000,000 \mathrm{~g}}=4206 \text { tonnes }
$$


Table 18: Results of emissions analysis in tonnes $\mathrm{CO}_{2} \mathrm{eq}$

\begin{tabular}{|l|c|c|}
\hline & MURB Heating (tonnes) & Data Centre Cooling (tonnes) \\
\hline Energy Requirement & $17,735 \mathrm{MWh}$ & $17,646 \mathrm{MWh}$ \\
\hline Existing Total Emissions & 4206 & 132 \\
\hline Existing Capacity & 1886 & 65 \\
\hline Energy Sharing & 100 & 0.1 \\
\hline Scenario 1 GHG Savings & $2220(53 \%)$ & $67(51 \%)$ \\
\hline Existing Capacity & 530 & 6 \\
\hline Energy Sharing & 100 & 0.1 \\
\hline Scenario 2 Geo-exchange & 60 & 52 \\
\hline Scenario 2 Cooling Tower Emissions & & 10 \\
\hline Scenario 2 GHG Savings & $3306(79 \%)$ & $74(56 \%)$ \\
\hline Existing Capacity & 530 & 6 \\
\hline Energy Sharing & 100 & 0.1 \\
\hline Scenario 3 Geo-exchange & 55 & 0.3 \\
\hline Scenario 3 Dry Cooler & & 18 \\
\hline Scenario 3 GHG Savings & $3522(84 \%)$ & $108(82 \%)$ \\
\hline
\end{tabular}

Emissions savings from switching from natural gas heating to geo-exchange are substantial because the carbon intensity of electricity in Ontario is already 3.5 times less than natural gas, before considering the fact that GSHP heating is four to five times more energy efficient than natural gas equipment. Scenario 3 has the largest emssions savings because the network is delivering more energy than Scenario 1 and both heating and cooling are more efficient than Scenario 2 .

The Two-Borefield System would reduce 105,660 tonnes of equivalent $\mathrm{CO}_{2}$ emissions over 30 years. This scenario would need $15 \%$ capital funding, or $\$ 1.45$ million to meet an $8 \%$ IRR as shown in Table 17. Dividing the $\$ 1.45$ million capital funding required by the project life emissions reductions results in a value of $\$ 14 /$ tonne $\mathrm{CO}_{2} \mathrm{e}$. This means that if carbon tax increased by $\$ 14 /$ tonne additional to the assumed $\$ 20 /$ tonne this scenario would be financially viable. 


\subsection{Chapter Summary}

The scope of this paper is to determine the optimum way to create a CEN, serving a data centre and several MURBs. The first scenario demonstrated the simplicity of only energy sharing, the second scenario layered in standard geo-exchange as an energy source and the third scenario was a unique approach to achieving free cooling, tailored to the high data centre chilled water supply temperature. Scenarios 1 and 2 were simulated in GLD, while Scenario 3 was simulated in TRNSYS. The simulation results were then used in a custom Microsoft Excel model which compared each scenario on a financial basis. Each scenario's GHG emissions savings were also calculated to contextualize their benefit. The following are significant findings and conclusions from the analysis and scenario evaluation.

\section{Community Energy Network}

- The optimal MURB area that should be connected to a 4 MW cooling load data centre is $110,000 \mathrm{~m}^{2}$ in Toronto, Canada.

- The project considers that data centres should receive a $25 \%$ reduction in cooling costs, so that they are enticed to participate in the project.

\section{Energy Sharing System}

- The scenario of only energy sharing was the most profitable, with a $11.9 \% 30$-year aftertax IRR.

- The scenario resulted in the most efficient operation, achieving a $4.3 \mathrm{COP}$ for heating and free cooling.

- This scenario would reduce the MURBs' annual heating related GHG emissions by 2220 tonnes (53\%) and reduce the data centre's annual cooling related GHG emissions by 67 tonnes $(51 \%)$.

\section{$\underline{\text { One-Borefield System }}$}


- This scenario performed slightly better than the Two-Borefield System because of its significantly lower capital cost.

- This scenario achieved an 7.8\% 30-year after-tax IRR.

- This scenario would reduce the MURBs' annual heating related GHG emissions by 3306 tonnes $(79 \%)$ and reduce the data centre's annual cooling related GHG emissions by 74 tonnes $(56 \%)$.

\section{$\underline{\text { Two-Borefield System }}$}

- This scenario required $15 \%$ of the total capital cost in funding to achieve an $8 \% 30$-year after-tax IRR.

- This scenario would reduce the MURBs' annual heating related GHG emissions by 3522 tonnes (84\%) and reduce the data centre's annual cooling related GHG emissions by 108 tonnes $(82 \%)$.

- If carbon tax increased by an additional \$14/tonne this scenario would be financially viable. This study demonstrated the financial and carbon benefit an existing community with a data centre can have if a district energy approach is applied. The Energy Sharing System (Scenario 1) is the recommended system because of its high returns, its simplicity and the fact that it will financially improve with scale because $75 \%$ of the capital cost is fixed.

Further research could be of benefit. A sensitivity analysis should be conducted to determine which parameters are the most sensitive and therefore may need more reliable data. The sensitivity analysis should also include testing the project in other cities. Finally, an experimental analysis could be conducted for the cold borefield of the Two-Borefield System, to determine if local ground freezing improves the system results. 


\section{CHAPTER IV - Sensitivity Analysis}

Corresponding Manuscript: A.R. Murphy, A.S. Fung, "Sensitivity Analysis of an Energy Sharing Network Comprised of a Data Centre and Multi-Unit Residential Buildings for Cold Climate", Energy and Buildings, Submission Date: July 31 ${ }^{\text {st }}, 2018$, Manuscript Reference:

ENB_2018_2270.

\subsection{Introduction}

Due to their significant internal heat gain resulting from computer server banks, data centres require cooling year-round, creating an opportunity to transport the waste heat to heatdeficient neighbouring buildings. Chapter 3 evaluated the financial viability of three different methods with which energy can be shared from a data centre to surrounding MURBs in a community energy network (CEN). The first method, called the Energy Sharing System involves using a heat pump to produce heating and cooling at the same time for the MURBs and the data centre. The second, called the One-Borefield System, has the same energy sharing aspect as the first, with additional heating and cooling coming from geo-exchange. The third method, called the Two-Borefield System, is an innovative approach to geo-exchange, which uses two separate borefields to achieve free cooling, while also incorporating the energy sharing base. To solidify the results presented in Chapter 3, a sensitivity analysis was carried out to determine which variables were most important to the prediction of the overall project viability. In addition, the project sensitivity was tested in five other cities: Montreal, Chicago, New York City, Winnipeg and Vancouver, to determine if this project would be applicable in a wide range of cities.

The sensitivity of the heating and cooling COPs to different supply temperatures will be simulated. The sensitivity of the borefield models to changes in thermal conductivity will also be assessed, as it can vary even over short distances and cannot be completely proven until a conductivity test is performed for the specific site. The sensitivity of the financial model will also be assessed, by varying the capital cost as well as the carbon tax, natural gas and electricity 
escalation rates. The sensitivity of the project to data centre size was also tested. Finally, the city sensitivity analysis will include modifying the electricity and natural gas rates, as well as the undisturbed ground temperature to reflect the project conditions of the five selected cities.

\subsection{Methodology}

To determine which variables are most sensitive to overall project viability each parameter was adjusted by $-20 \%,-10 \%,+10 \%$ and $+20 \%$, where possible. An example of when the variable could not be changed by these percentages is the testing of the heating and cooling supply temperatures. These were varied by a threshold of temperatures that could occur in the HVAC industry, as changing absolute temperature by 10 and 20\%, would be drastic and unrealistic. After each variable was changed, a new IRR was calculated and plotted on a graph for comparison. The variables which produced the steepest slope on the graph were then the most sensitive variables to the project.

The sensitivity of the project to implementation in different cities required changing several variables. The natural gas and electricity prices needed to be determined for each city, as well as differences in ground temperature, which affects heat pump efficiencies and the ground loop requirement. The chosen cities also contained a significant quantity of data centres, located in dense areas. The results from the sensitivity analysis of individual variables were used to explain the differences in IRR across the five additional cities that were tested.

The city sensitivity analysis maintained the same heating and cooling load profiles for the MURBs and the data centre. This is because this project seeks to strike the right balance between data centre cooling and MURB heating - as long as the heating season is of similar length (November to April), the heating energy intensity is not a critical factor. Also, the cooling requirement of a data centre is not highly dependent on outdoor air temperature. 


\subsection{Sensitivity of Energy Model}

The first step to conducting a full sensitivity analysis was testing the energy model. The cooling supply temperature was changed from $10^{\circ} \mathrm{C}$ to $8,9,11$ and $12^{\circ} \mathrm{C}$. A chilled water supply temperature of $8^{\circ} \mathrm{C}$ would suit a more conservative data centre, while supply temperatures of $12^{\circ} \mathrm{C}$ have also been referenced in literature [12]. The results of this analysis are shown in Table 19 and Figures 43-45.

Table 19: Summarization of results from the chilled water supply temperature sensitivity analysis, showing the change in IRR and any other variables which changed during the analysis

\begin{tabular}{|c|c|c|c|c|c|c|c|}
\hline & \multicolumn{2}{|c|}{ Energy Sharing } & \multicolumn{2}{c|}{ One-Borefield } & \multicolumn{3}{c|}{ Two-Borefield } \\
\hline CHWS & $\begin{array}{c}\% \text { Change } \\
\text { in IRR }\end{array}$ & $\begin{array}{c}\text { Heating } \\
\text { COP }\end{array}$ & $\begin{array}{c}\text { \% Change } \\
\text { in IRR }\end{array}$ & $\begin{array}{c}\text { Cooling } \\
\text { COP }\end{array}$ & $\begin{array}{c}\text { \% Change } \\
\text { in IRR }\end{array}$ & $\begin{array}{c}\text { Heating } \\
\text { COP }\end{array}$ & \# of BH \\
\hline $8^{\circ} \mathrm{C}$ & $-3.9 \%$ & 4.10 & $-4.5 \%$ & 8.00 & $-43.1 \%$ & 3.84 & 1000 \\
\hline $9^{\circ} \mathrm{C}$ & $-0.8 \%$ & 4.22 & $-1.1 \%$ & 8.05 & $-13.4 \%$ & 3.86 & 680 \\
\hline $10^{\circ} \mathrm{C}$ & $0.0 \%$ & 4.25 & $0.0 \%$ & 8.17 & $0.0 \%$ & 3.88 & 570 \\
\hline $11^{\circ} \mathrm{C}$ & $2.3 \%$ & 4.34 & $2.8 \%$ & 8.33 & $8.5 \%$ & 3.91 & 520 \\
\hline $12^{\circ} \mathrm{C}$ & $4.4 \%$ & 4.43 & $5.6 \%$ & 8.56 & $13.1 \%$ & 3.93 & 500 \\
\hline
\end{tabular}

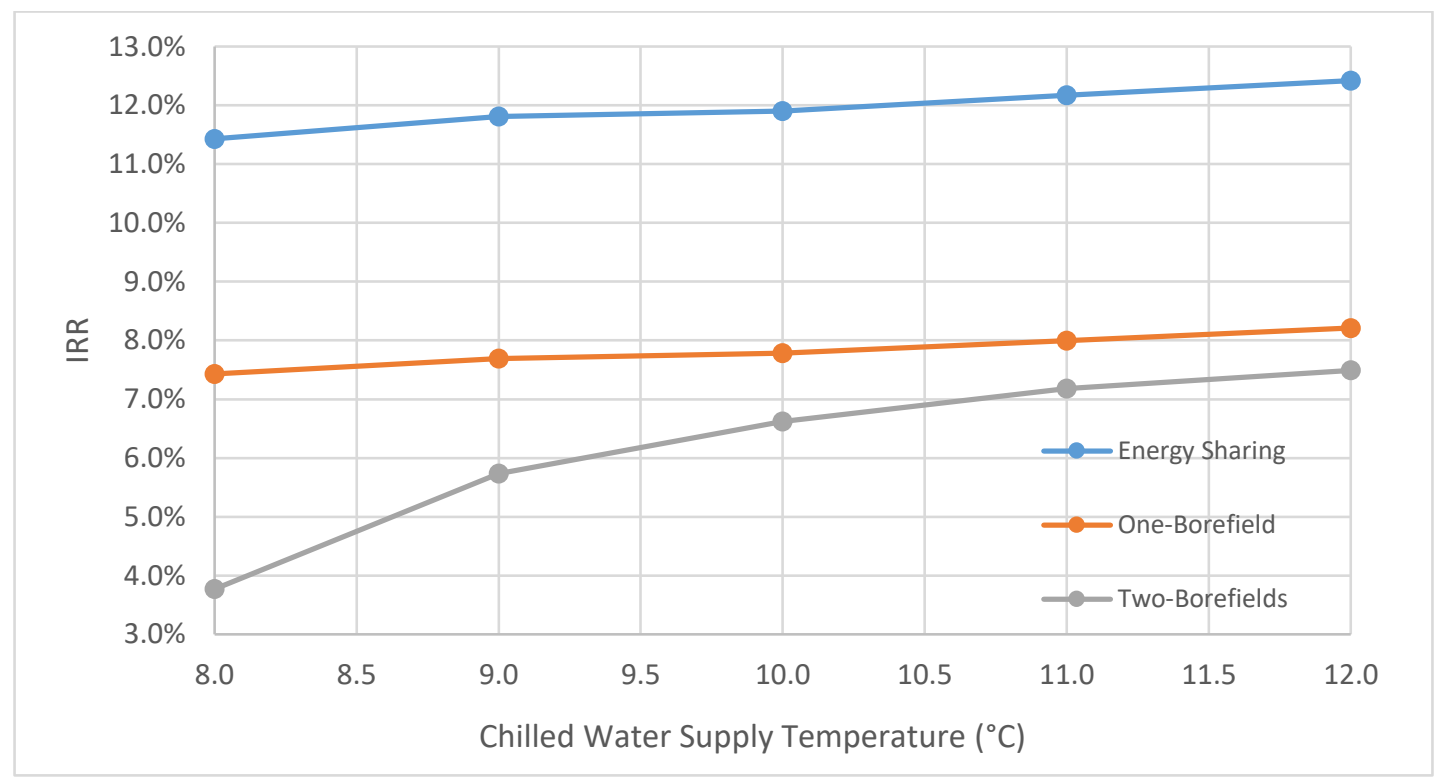

Figure 43: 30-year after-tax IRR for each scenario, testing the sensitivity of an 8, 9, 10, 11 and $12^{\circ} \mathrm{C}$ chilled water supply temperature 


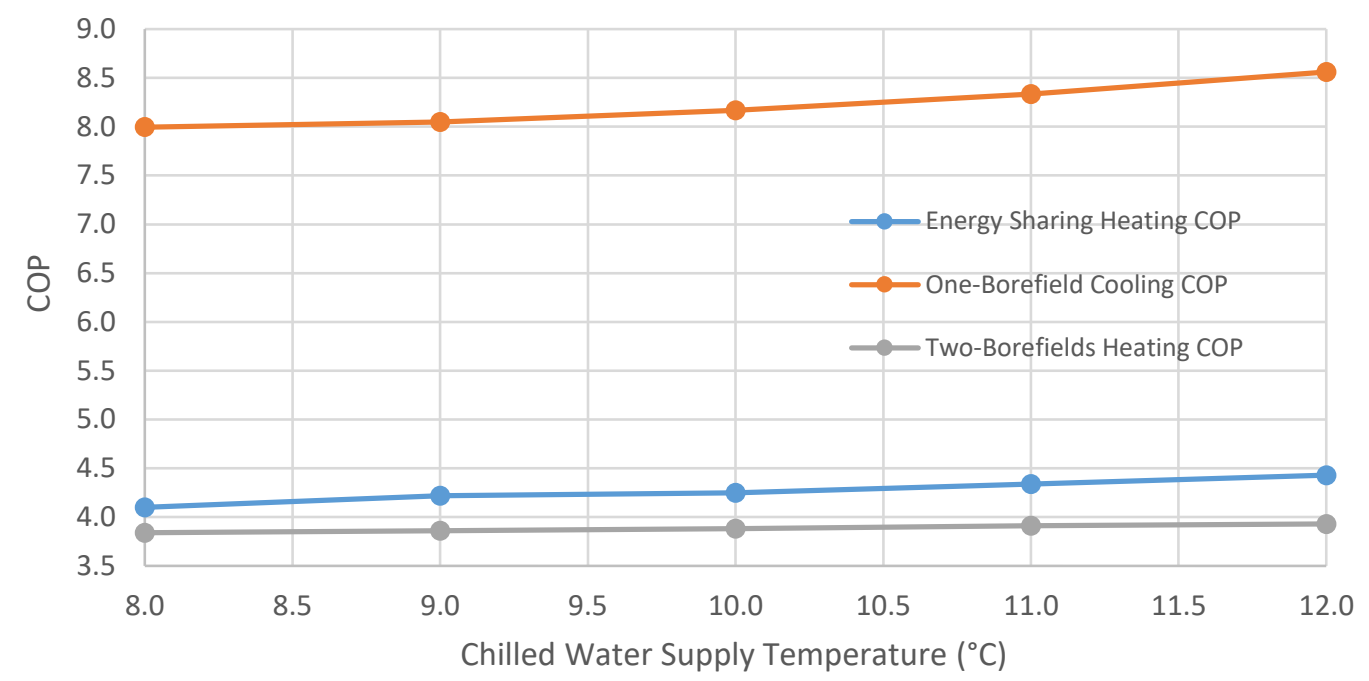

Figure 44: COPs which changed as a result of the chilled water supply temperature sensitivity analysis

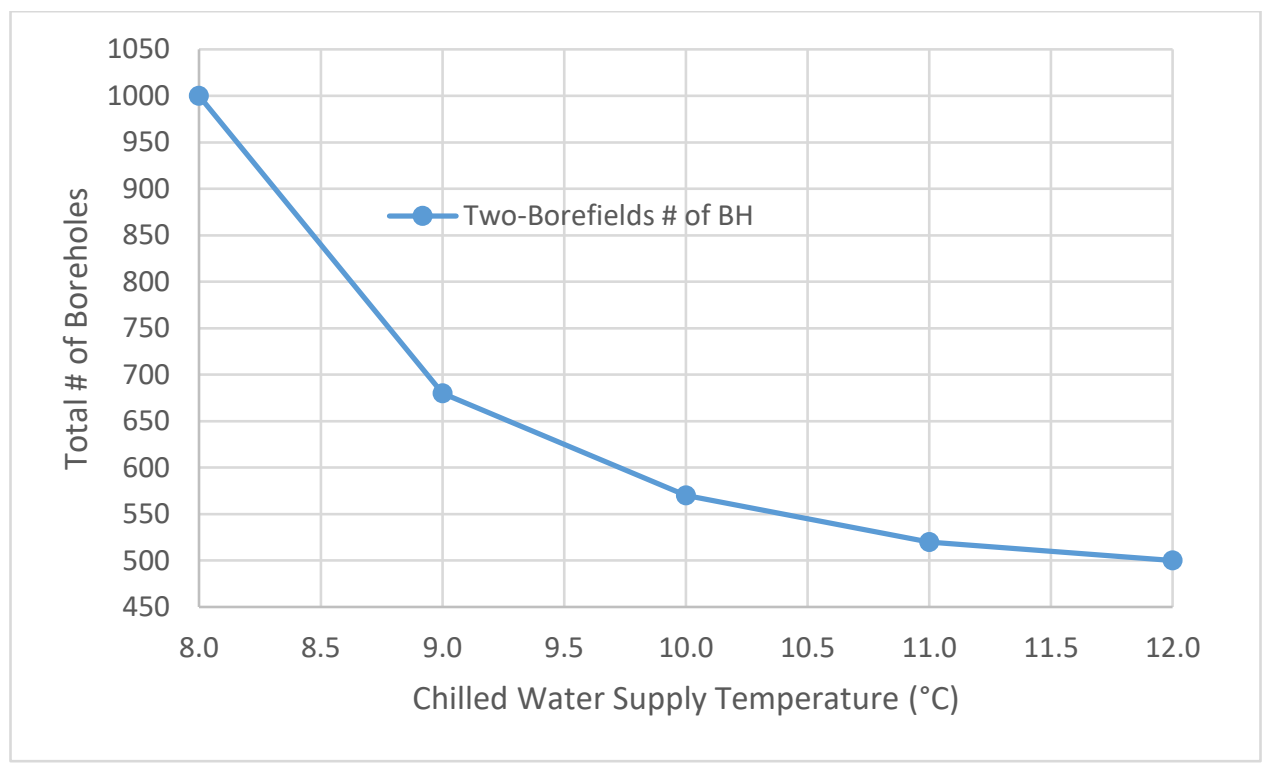

Figure 45: Number of required boreholes which changed as a result of the heating water supply temperature sensitivity analysis

The change in chilled water supply temperature had the largest effect on the Two-Borefield System (as seen in Figure 45) because it directly affected the number of boreholes required for free cooling, ultimately changing the capital cost. The Two-Borefield System required 70 less boreholes for the cold field to achieve a supply temperature of $12^{\circ} \mathrm{C}$, but required 430 more boreholes to achieve an $8^{\circ} \mathrm{C}$ supply temperature. When the required chilled water supply 
temperature was high, the dry cooler could provide free cooling for a larger portion of the load. Additionally, since the undisturbed ground temperature in Toronto is $10^{\circ} \mathrm{C}$, the borefield was resistant to maintaining the leaving fluid temperature from the borefield at $8^{\circ} \mathrm{C}$. The Energy Sharing System and the One-Borefield System only experienced a change in heat pump efficiency (as seen in Figure 44), which affected the operation cost slightly, and consequently, the IRR.

The weighted average heating supply temperature to enter fan coils in MURBs was changed from $39^{\circ} \mathrm{C}$ to $33,36,42$ and $45^{\circ} \mathrm{C}$. An average heating supply temperature of $33^{\circ} \mathrm{C}$ could occur in highly efficient building, or a building with radiant in floor heating. An average heating supply temperature of $45^{\circ} \mathrm{C}$ could be common in a building with a higher design heating supply temperature than $60^{\circ} \mathrm{C}$ or a building which experiences high part loads frequently. The results of this analysis are shown in

Table 20 and Figures 46-48.

Table 20: Summarization of results from the heating water supply temperature sensitivity analysis, showing the change in IRR and any other variables which changed during the analysis

\begin{tabular}{|c|c|c|c|c|c|c|c|c|c|}
\hline & Energy Sharing & \multicolumn{4}{|c|}{ One-Borefield } & \multicolumn{3}{c|}{ Two-Borefield } \\
\hline HWS & $\begin{array}{c}\text { \% Change } \\
\text { in IRR }\end{array}$ & $\begin{array}{c}\text { Heating } \\
\text { COP }\end{array}$ & $\begin{array}{c}\text { \% Change } \\
\text { in IRR }\end{array}$ & $\begin{array}{c}\text { Heating } \\
\text { COP }\end{array}$ & $\begin{array}{c}\text { Cooling } \\
\text { COP }\end{array}$ & $\begin{array}{c}\text { \# of } \\
\text { BH }\end{array}$ & $\begin{array}{c}\text { \% Change in } \\
\text { IRR }\end{array}$ & $\begin{array}{c}\text { Heating } \\
\text { COP }\end{array}$ & $\begin{array}{c}\text { \# of } \\
\text { BH }\end{array}$ \\
\hline $33^{\circ} \mathrm{C}$ & $10.7 \%$ & 4.72 & $14.5 \%$ & 3.89 & 8.30 & 209 & $12.4 \%$ & 4.60 & 579 \\
\hline $36^{\circ} \mathrm{C}$ & $5.0 \%$ & 4.46 & $6.9 \%$ & 3.69 & 8.22 & 205 & $6.0 \%$ & 4.21 & 575 \\
\hline $39^{\circ} \mathrm{C}$ & $0.0 \%$ & 4.25 & $0.0 \%$ & 3.52 & 8.17 & 200 & $0.0 \%$ & 3.88 & 570 \\
\hline $42^{\circ} \mathrm{C}$ & $-3.9 \%$ & 4.10 & $-5.3 \%$ & 3.41 & 8.13 & 196 & $-5.4 \%$ & 3.60 & 566 \\
\hline $45^{\circ} \mathrm{C}$ & $-7.4 \%$ & 3.98 & $-11.0 \%$ & 3.30 & 8.00 & 194 & $-11.2 \%$ & 3.35 & 564 \\
\hline
\end{tabular}


Figure 46: 30-year after-tax IRR for each scenario, testing the sensitivity of a 33, 36, 39, 42 and $45^{\circ} \mathrm{C}$ weighted average heating water supply temperature

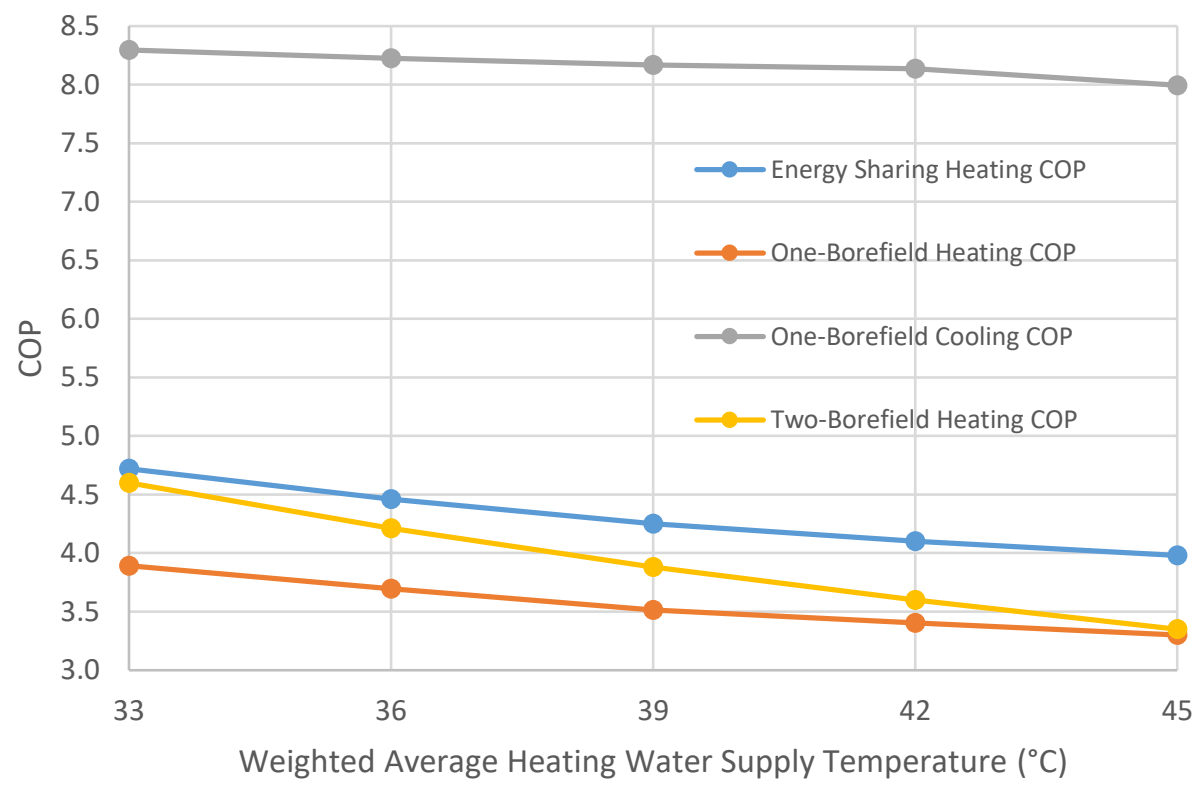

Figure 47: COPs which changed as a result of the heating water supply temperature sensitivity analysis 


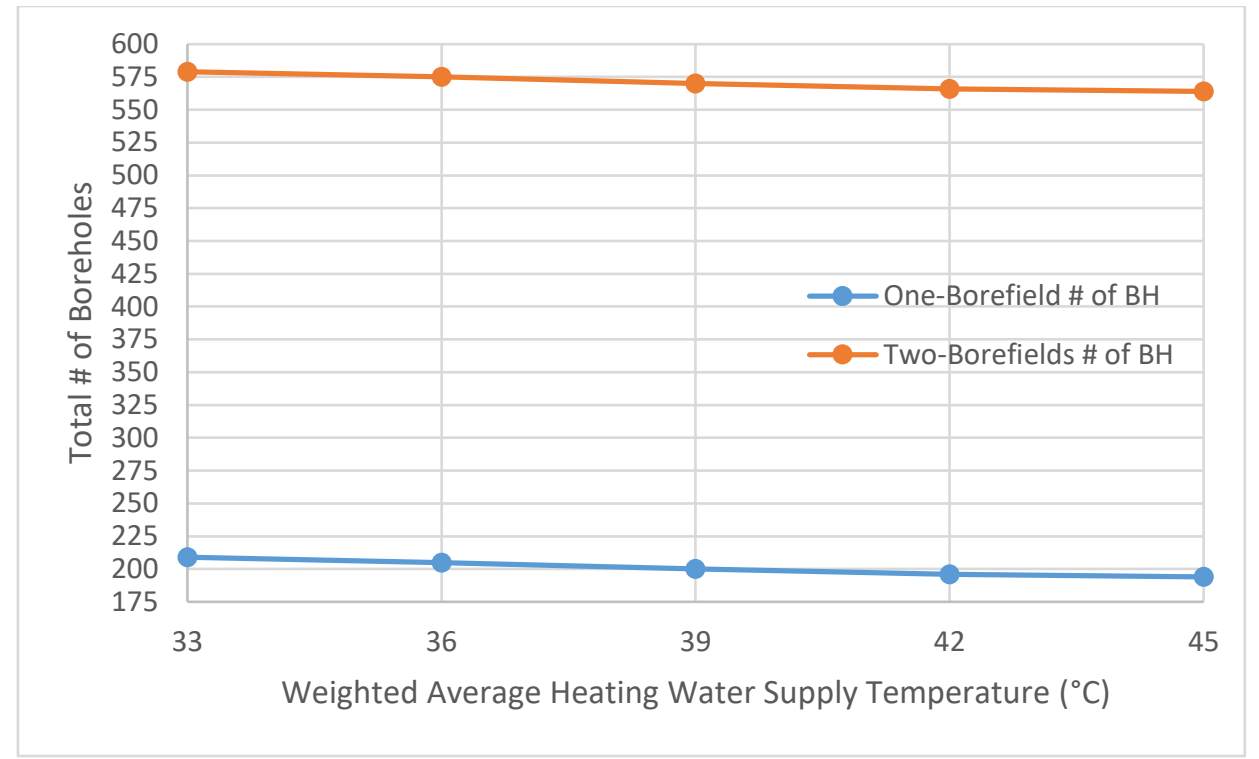

\section{Figure 48: Number of required boreholes which changed as a result of the heating water supply temperature sensitivity analysis}

Figure 47 demonstrates that the change in heating supply temperature significantly affected the heating COP in all scenarios. In the geo-exchange scenarios, the number of boreholes had to be increased by nine because of increased heat pump efficiency at lower heating supply temperatures, and decreased by six because of decreased heat pump efficiency at higher heating supply temperatures (shown in Figure 48). At lower heat pump efficiencies, the electrical work inputted into the heat pump provides a larger portion of the required heating and therefore relies on the borefield less. This effect counteracts the change in heat pump efficiencies and slightly reduces the sensitivity of changing the heating supply temperature variable. Figure 47 also shows a slight change in cooling COP because of the change in the number of boreholes.

The thermal conductivity of the ground was changed by 10 and $20 \%$ from 2.94 to 2.45 , 2.67, 3.23 and $3.53 \mathrm{~W} / \mathrm{mK}$. Thermal conductivity is a wise variable to test because it cannot be completely confirmed until a conductivity test is conducted at the site in question, which requires drilling a test hole. Additionally, in the Two-Borefield System, the thermal conductivity used in TRNSYS may be low because the ground in the cold borefield experiences freezing near the bore 
holes for a significant portion of time. Frozen shale will have higher conductivity than when it is thawed; however, this was not captured in the main analysis due to the difficulty of predicting the amount of soil that froze, and exactly how much it increased the thermal conductivity without a detailed finite element model. Table 21 and Figures 49 and 50 show the results of varying the thermal conductivity by 10 and $20 \%$.

Table 21: Summarization of results from the thermal conductivity sensitivity analysis, showing the change in IRR and any other variables which changed during the analysis

\begin{tabular}{|c|c|c|c|c|}
\hline & \multicolumn{2}{|c|}{ One-Borefield } & \multicolumn{2}{c|}{ Two-Borefield } \\
\hline $\begin{array}{c}\text { Thermal } \\
\text { Conductivity }\end{array}$ & $\begin{array}{c}\text { \% Change in } \\
\text { IRR }\end{array}$ & $\begin{array}{c}\text { \# of } \\
\text { BH }\end{array}$ & $\begin{array}{c}\text { \% Change in } \\
\text { IRR }\end{array}$ & \# of BH \\
\hline $2.45 \mathrm{~W} / \mathrm{mK}$ & $-5.5 \%$ & 232 & $-8.6 \%$ & 640 \\
\hline $2.67 \mathrm{~W} / \mathrm{mK}$ & $-2.7 \%$ & 216 & $-5.0 \%$ & 610 \\
\hline $2.94 \mathrm{~W} / \mathrm{mK}$ & $0.0 \%$ & 200 & $0.0 \%$ & 570 \\
\hline $3.23 \mathrm{~W} / \mathrm{mK}$ & $2.6 \%$ & 187 & $2.1 \%$ & 555 \\
\hline $3.53 \mathrm{~W} / \mathrm{mK}$ & $5.0 \%$ & 175 & $4.2 \%$ & 540 \\
\hline
\end{tabular}

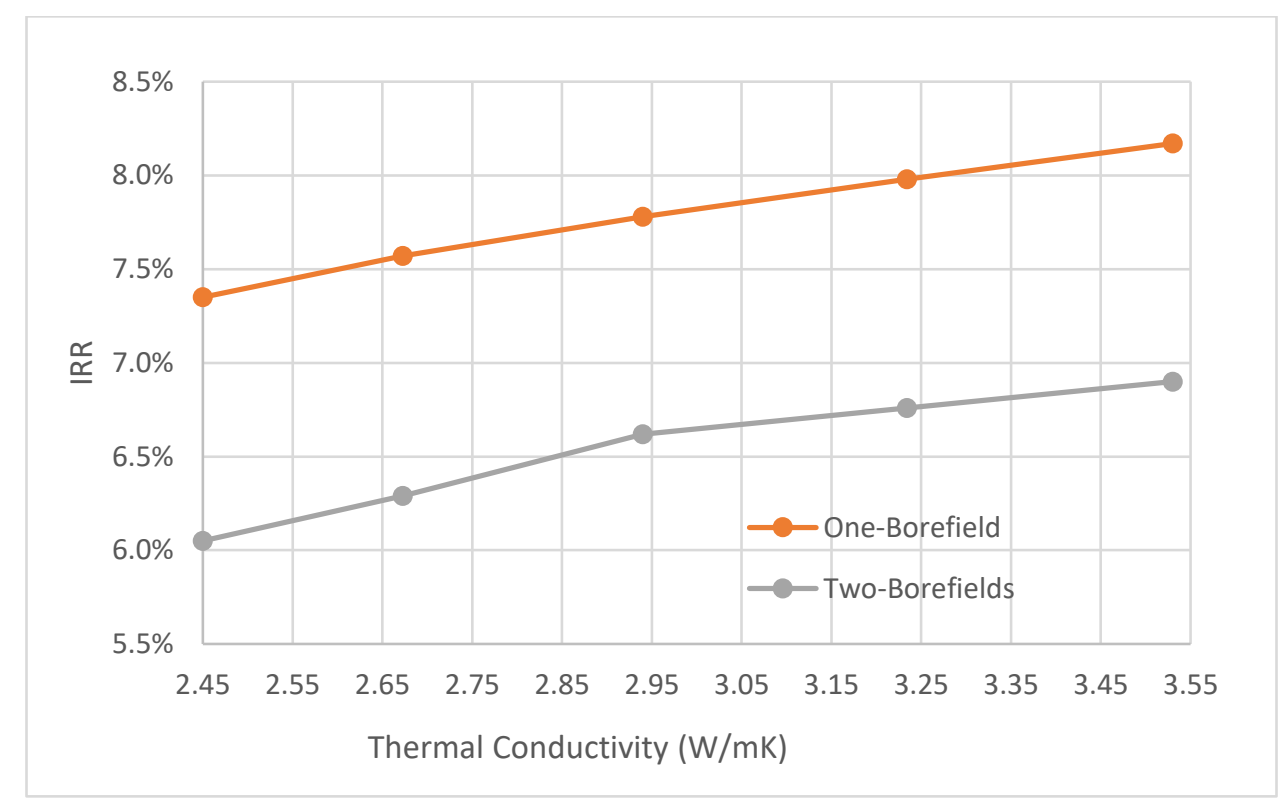

Figure 49: 30-year after-tax IRR for each scenario, testing the sensitivity of a 2.45, 2.67, 2.94, 3.23 and $3.53 \mathrm{~W} / \mathrm{mK}$ thermal conductivity 


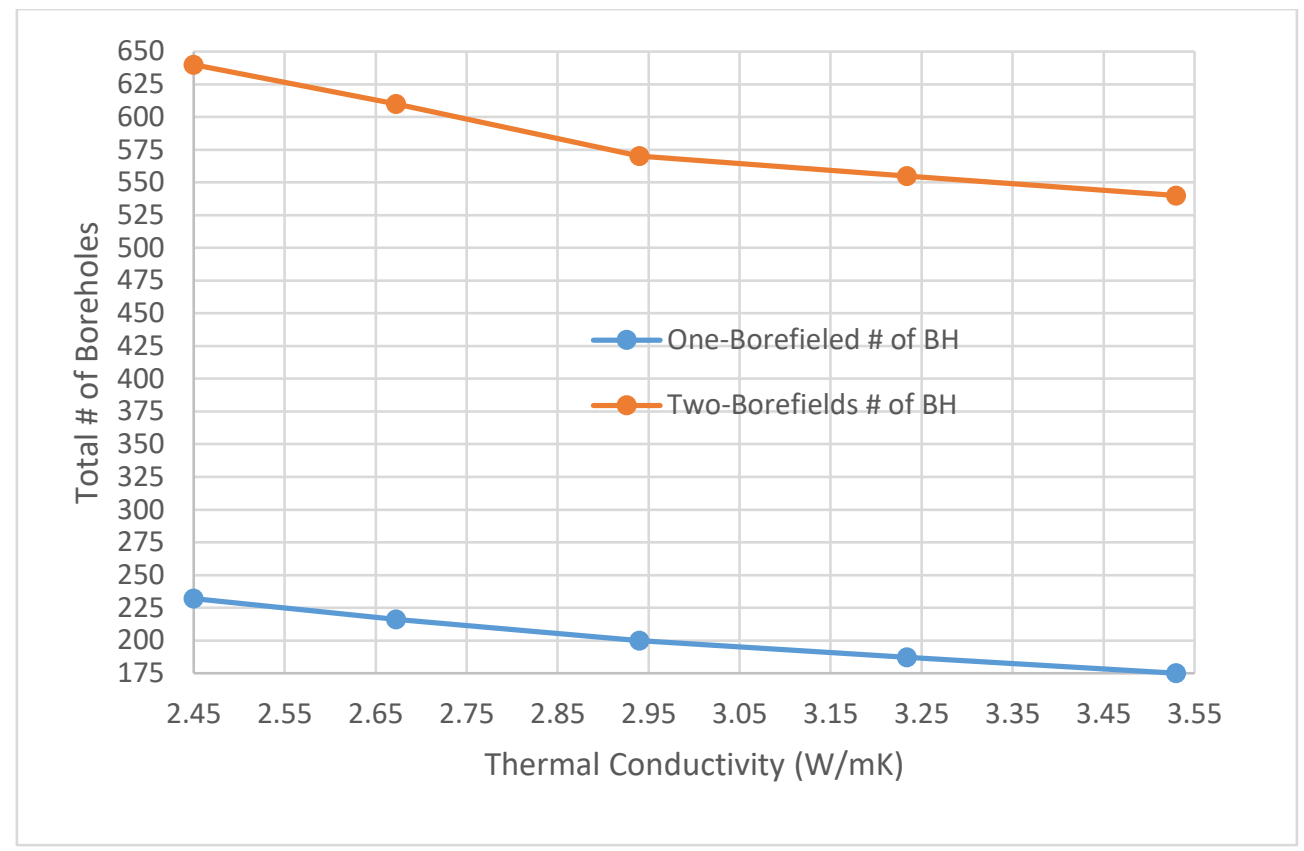

\section{Figure 50: Number of required boreholes which changed as a result of the thermal conductivity sensitivity analysis}

In both the One- and Two-Borefield Systems, the change in ground thermal conductivity responded as expected, the heat pump COPs did not change, but less ground loop was required when thermal conductivity was increased, and more was required when it was decreased, as shown in Figure 50. Overall, these simulations indicate that thermal conductivity is one of the least sensitive variables.

Ground temperature is a parameter that can be accurately predicted and will be a key factor in comparing the project implementation in other cities. The ground temperature was changed from $10^{\circ} \mathrm{C}$ to $8,9,11$ and $12^{\circ} \mathrm{C}$. Table 22 and Figures $51-53$ show the results of the ground temperature variance analysis. 
Table 22: Summarization of results from the undisturbed ground temperature sensitivity analysis, showing the change in IRR and any other variables which changed during the analysis

\begin{tabular}{|c|c|c|c|c|c|c|c|}
\hline & \multicolumn{4}{|c|}{ One-Borefield } & \multicolumn{3}{c|}{ Two-Borefield } \\
\hline $\begin{array}{c}\text { Ground } \\
\text { Temperature }\end{array}$ & $\begin{array}{c}\text { \% Change } \\
\text { in IRR }\end{array}$ & $\begin{array}{c}\text { Heating } \\
\text { COP }\end{array}$ & $\begin{array}{c}\text { Cooling } \\
\text { COP }\end{array}$ & $\begin{array}{c}\text { \# of } \\
\text { BH }\end{array}$ & $\begin{array}{c}\text { C Change } \\
\text { in IRR }\end{array}$ & $\begin{array}{c}\text { Heating } \\
\text { COP }\end{array}$ & $\begin{array}{c}\text { \# of } \\
\text { BH }\end{array}$ \\
\hline $8^{\circ} \mathrm{C}$ & $-7.1 \%$ & 3.41 & 9.01 & 242 & $7.9 \%$ & 3.87 & 510 \\
\hline $9^{\circ} \mathrm{C}$ & $-3.5 \%$ & 3.46 & 8.60 & 220 & $4.5 \%$ & 3.88 & 535 \\
\hline $10^{\circ} \mathrm{C}$ & $0.0 \%$ & 3.52 & 8.17 & 200 & $0.0 \%$ & 3.88 & 570 \\
\hline $11^{\circ} \mathrm{C}$ & $2.4 \%$ & 3.57 & 7.76 & 185 & $-7.7 \%$ & 3.89 & 635 \\
\hline $12^{\circ} \mathrm{C}$ & $5.1 \%$ & 3.66 & 7.36 & 172 & $-15.6 \%$ & 3.90 & 710 \\
\hline
\end{tabular}

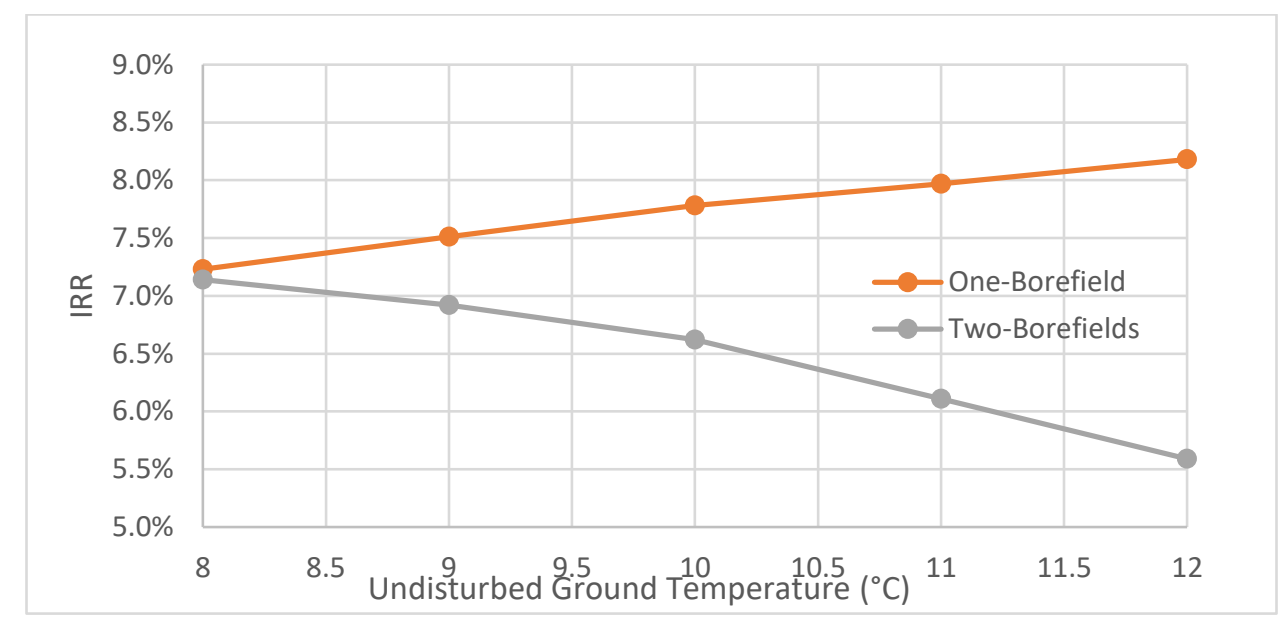

Figure 51: 30-year after-tax IRR for each scenario, testing the sensitivity of an 8, 9, 10, 11 and $12^{\circ} \mathrm{C}$ undisturbed ground temperature

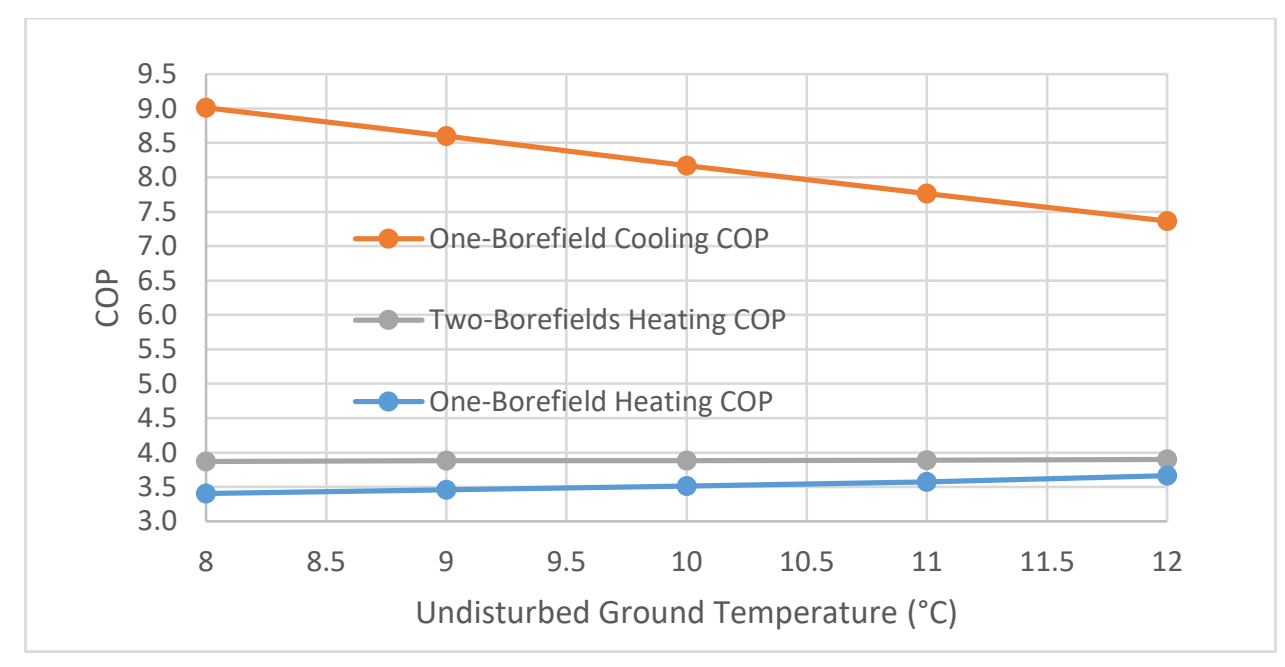

Figure 52: COPs which changed as a result of the undisturbed ground temperature sensitivity analysis 


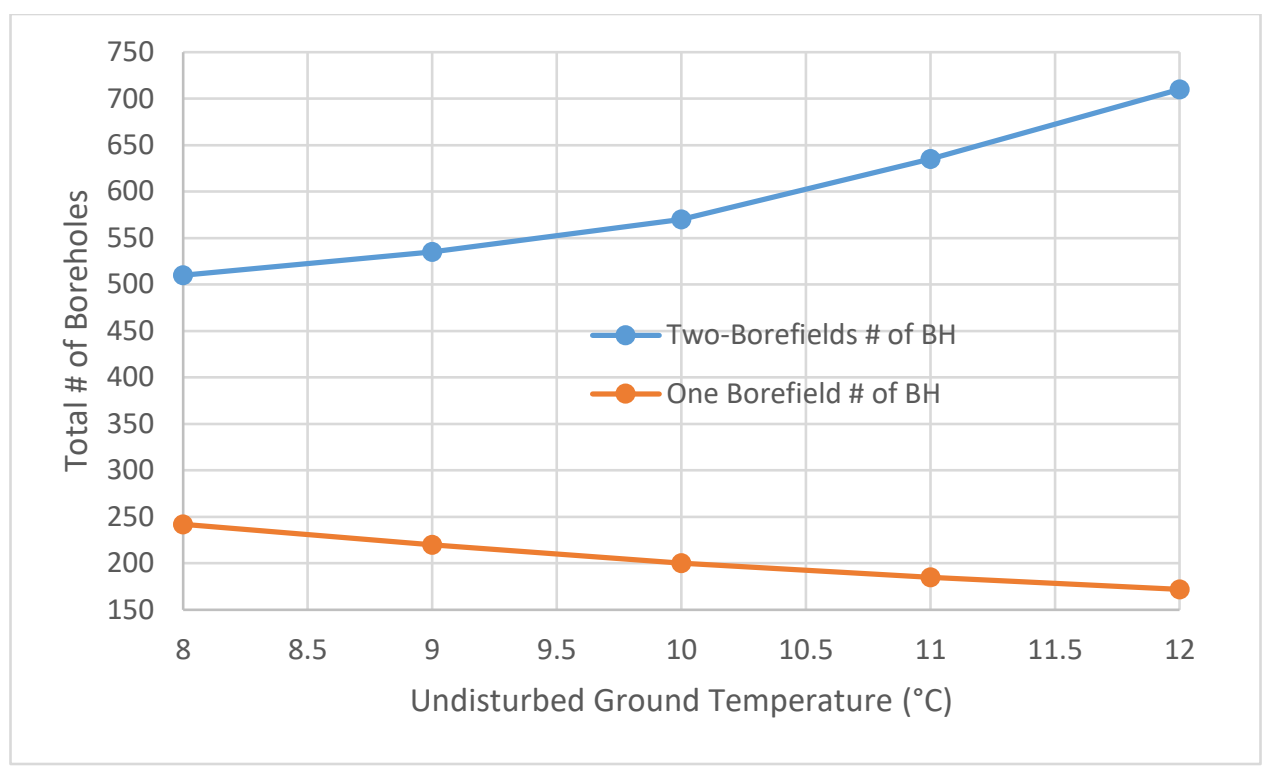

\section{Figure 53: Number of required boreholes which changed as a result of the undisturbed ground temperature sensitivity analysis}

In the One-Borefield System the limiting factor for borefield size is the fluid temperature entering the heat pump below $-1^{\circ} \mathrm{C}$ in heating mode. When the undisturbed ground temperature is higher there is more room for low temperature swings, which allows for less boreholes, as shown in Figure 53. The One-Borefield System also saw a slight increase in heating COP and decrease in cooling COP at higher undisturbed ground temperatures, as shown in Figure 52. The change in heating and cooling COPs counteracted themselves, which resulted in the change in number of boreholes to be the factor that changed the outcome of this simulation. The Two-Borefield System responded differently to the adjustment in ground temperature. The heating COP increased slightly with increased ground temperature, but the cooling borefield needed 140 more boreholes at a ground temperature of $12^{\circ} \mathrm{C}$ to achieve the chilled water supply temperature of $10^{\circ} \mathrm{C}$. At an $8^{\circ} \mathrm{C}$ ground temperature, the cold borefield required 60 less boreholes, showing a large net benefit, despite the slight decrease in heating COP.

In summary, the most sensitive energy model variable for all the scenarios was the change in heating supply temperature. This is typical for a district system because building heating supply 
temperatures can vary widely between buildings. This problem is underlined by the fact that centralized district energy systems, which do not have heat pumps at each building, need to have a heating water supply temperature equal to that of the highest temperature building. The most sensitive variable for the Two-Borefield System was the data centre's chilled water supply temperature. The analysis found that at $8^{\circ} \mathrm{C}$, the Two-Borefield System is simply infeasible, as the dry cooler cannot operate as often. This is because there is less time in the year in which the air temperature is less than $8^{\circ} \mathrm{C}$ and the ground temperature is too high. An $8^{\circ} \mathrm{C}$ chilled water supply temperature would preclude data centres that are designed conservatively from participating in the project, however, most data centres have a cooling supply temperature of $10^{\circ} \mathrm{C}$ and above. This is because the air temperature only needs to be between 18 and $27^{\circ} \mathrm{C}$ because these spaces are not designed for human comfort [7] [12].

\subsection{Sensitivity of Financial Model}

The second step of conducting a full sensitivity analysis was testing the financial model.

The sensitivity of the capital cost is an important variable to test because there can often be unforeseen added costs to a project, or there may be unexpected cost savings. The capital cost of each scenario was increased and decreased by 10 and 20\%, with the results shown in Table 23 and Figure 54.

Table 23: Summarization of results from the capital cost sensitivity analysis, showing the change in IRR and any other variables which changed during the analysis

\begin{tabular}{|c|c|c|c|}
\hline & Energy Sharing & One-Borefield & Two-Borefield \\
\hline $\begin{array}{c}\text { Change in Capital } \\
\text { Cost }\end{array}$ & \% Change in IRR & \% Change in IRR & \% Change in IRR \\
\hline$-20 \%$ & $17.6 \%$ & $20.2 \%$ & $22.2 \%$ \\
\hline$-10 \%$ & $8.9 \%$ & $10.3 \%$ & $11.3 \%$ \\
\hline $0 \%$ & $0.0 \%$ & $0.0 \%$ & $0.0 \%$ \\
\hline $10 \%$ & $-8.2 \%$ & $-9.8 \%$ & $-10.9 \%$ \\
\hline $20 \%$ & $-15.3 \%$ & $-18.4 \%$ & $-20.2 \%$ \\
\hline
\end{tabular}




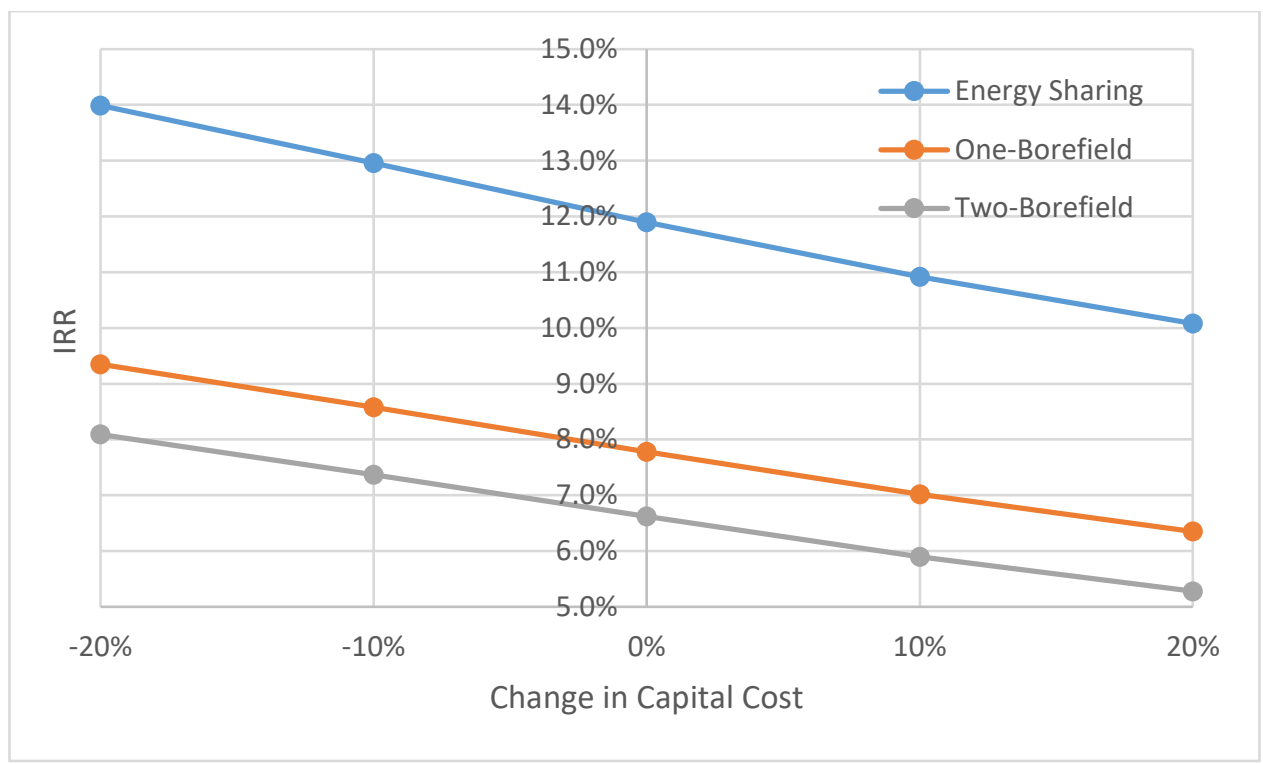

\section{Figure 54: 30-year after-tax IRR for each scenario, testing the sensitivity of changing the capital cost by $-20,-10,0,10$ and $20 \%$}

The analysis found that the sensitivity of the capital cost is higher in the scenarios with higher original capital cost. This is because the dollar amount of the change is larger. Even though the sensitivity of the scenarios which incorporate geo-exchange are higher, the risk of these projects may be overstated because the borefield installations are $37 \%$ and $62 \%$ of the total capital cost and the complexity of this installation is low compared to the building retrofits and the installation of the district pipes.

Changes in carbon tax escalation are also a very important variable to test because the future price is highly dependent on political decisions. Carbon tax is added to any commodity which produces $\mathrm{CO}_{2}$ emissions. In the case of natural gas, a carbon tax at $\$ 20 /$ tonne adds $8 \%$ to the natural gas rate in 2018. Testing the sensitivity of carbon tax escalation produces similar results to testing the escalation of the natural gas rate, so the escalation of the natural gas rate will not be tested. The carbon tax escalation rate was changed by 10 and $20 \%$, from $7 \%$ to $5.83,6.36,7.7$ and 8.4\%. Table 24 and Figures 55 and 56 show the results of this analysis. 
Table 24: Summarization of results from the carbon tax escalation rate sensitivity analysis, showing the change in IRR and any other variables which changed during the analysis

\begin{tabular}{|c|c|c|c|c|c|c|}
\hline & \multicolumn{2}{|c|}{ Energy Sharing } & \multicolumn{2}{c|}{ One-Borefield } & \multicolumn{2}{c|}{ Two-Borefield } \\
\hline $\begin{array}{c}\text { Carbon } \\
\text { Tax } \\
\text { Escalation }\end{array}$ & $\begin{array}{c}\text { \% Change } \\
\text { in IRR }\end{array}$ & $\begin{array}{c}\text { Heating } \\
\text { Gross Profit }\end{array}$ & $\begin{array}{c}\text { \% Change } \\
\text { in IRR }\end{array}$ & $\begin{array}{c}\text { Heating } \\
\text { Gross } \\
\text { Profit }\end{array}$ & $\begin{array}{c}\text { \% Change } \\
\text { in IRR }\end{array}$ & $\begin{array}{c}\text { Heating } \\
\text { Gross } \\
\text { Profit }\end{array}$ \\
\hline $5.83 \%$ & $-2.4 \%$ & $16.7 \%$ & $-5.1 \%$ & $14.1 \%$ & $-4.1 \%$ & $17.1 \%$ \\
\hline $6.36 \%$ & $-1.4 \%$ & $18.0 \%$ & $-2.8 \%$ & $15.4 \%$ & $-2.3 \%$ & $18.3 \%$ \\
\hline $7.00 \%$ & $0.0 \%$ & $19.6 \%$ & $0.0 \%$ & $17.1 \%$ & $0.0 \%$ & $19.9 \%$ \\
\hline $7.70 \%$ & $1.7 \%$ & $21.5 \%$ & $3.5 \%$ & $19.0 \%$ & $2.9 \%$ & $21.8 \%$ \\
\hline $8.40 \%$ & $3.4 \%$ & $23.6 \%$ & $7.1 \%$ & $21.0 \%$ & $5.9 \%$ & $23.7 \%$ \\
\hline
\end{tabular}

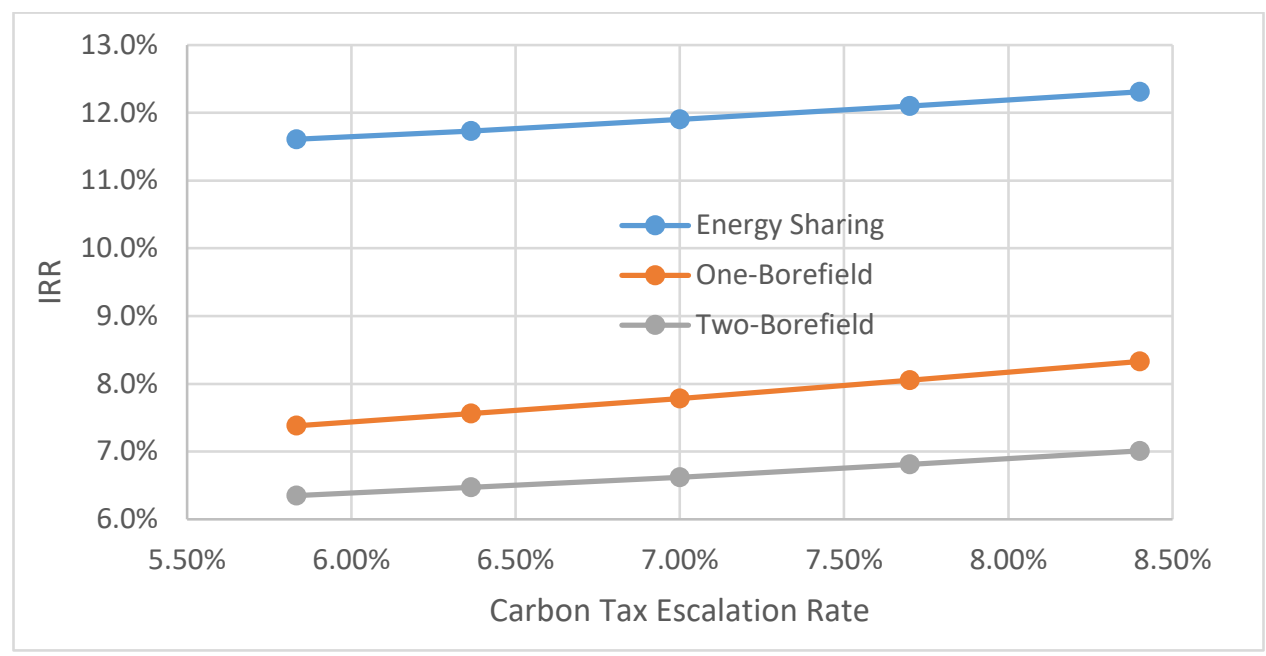

Figure 55: 30-year after-tax IRR for each scenario, testing the sensitivity of a 5.83, 6.36, 7, 7.7 and $8.4 \%$ carbon tax escalation rate

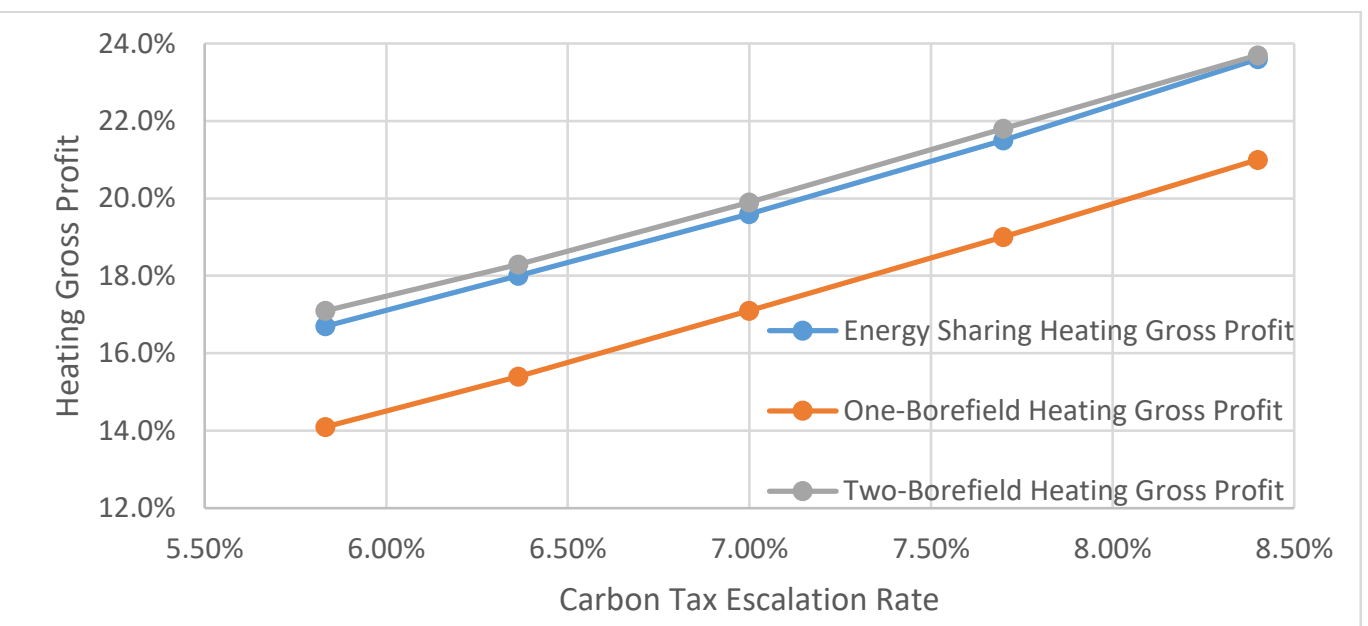

Figure 56: Change in heating gross profit as a result of the carbon tax escalation rate sensitivity analysis 
When carbon tax increases, the avoided cost of natural gas increases in the financial models. The reason the Energy Sharing System has the lowest sensitivity to changes in carbon tax is because this system is supplying less heating energy for the CEN, thus using more natural gas and receiving less of a benefit from this increase in avoided cost. The reason the Two-Borefield System is slightly less sensitive than the One-Borefield System is that the Two-Borefield System has lower heating operational costs. The One-Borefield System's thin heating gross profit margin is more affected by changes in avoided cost.

Changes in electricity escalation are difficult to predict because the future price is dependent on the type of generation systems that will installed, as well as political decisions. The electricity escalation rate was changed by 10 and 20\%, from 4\% up until 2027 to $3.33,3.64,4.4$ and $4.8 \%$, and from $2 \%$ between 2027 and the end of the project in 2049 to $1.67,1.82,2.2$ and 2.4\%. Table 25 and Figures 57 and 58 show the results of this analysis.

Table 25: Summarization of results from the electricity escalation rate sensitivity analysis, showing the change in IRR and any other variables which changed during the analysis

\begin{tabular}{|c|c|c|c|c|c|c|c|c|c|}
\hline \multicolumn{2}{|c|}{$\begin{array}{c}\text { Electricity } \\
\text { Escalation }\end{array}$} & \multicolumn{2}{c|}{ Energy Sharing } & \multicolumn{3}{c|}{ One-Borefield } & \multicolumn{3}{c|}{ Two-Borefield } \\
\hline Up to & After & $\begin{array}{c}\% \\
\text { Change } \\
\text { in IRR }\end{array}$ & $\begin{array}{c}\text { Heating } \\
\text { Gross } \\
\text { Profit }\end{array}$ & $\begin{array}{c}\% \\
\text { Change } \\
\text { in IRR }\end{array}$ & $\begin{array}{c}\text { Heating } \\
\text { Gross } \\
\text { Profit }\end{array}$ & $\begin{array}{c}\text { Cooling } \\
\text { Gross } \\
\text { Profit }\end{array}$ & $\begin{array}{c}\% \\
\text { Change } \\
\text { in IRR }\end{array}$ & $\begin{array}{c}\text { Heating } \\
\text { Gross } \\
\text { Profit }\end{array}$ & $\begin{array}{c}\text { Cooling } \\
\text { Gross } \\
\text { Profit }\end{array}$ \\
\hline $3.33 \%$ & $1.67 \%$ & $1.8 \%$ & $25.6 \%$ & $2.7 \%$ & $23.3 \%$ & $54.2 \%$ & $-0.5 \%$ & $23.8 \%$ & $87.5 \%$ \\
\hline $3.64 \%$ & $1.82 \%$ & $1.0 \%$ & $22.9 \%$ & $1.4 \%$ & $20.5 \%$ & $55.5 \%$ & $-0.3 \%$ & $22.1 \%$ & $87.4 \%$ \\
\hline $4.00 \%$ & $2.00 \%$ & $0.0 \%$ & $19.6 \%$ & $0.0 \%$ & $16.9 \%$ & $56.9 \%$ & $0.0 \%$ & $19.9 \%$ & $87.4 \%$ \\
\hline $4.40 \%$ & $2.20 \%$ & $-1.2 \%$ & $15.7 \%$ & $-1.7 \%$ & $13.1 \%$ & $58.5 \%$ & $0.3 \%$ & $17.4 \%$ & $87.3 \%$ \\
\hline $4.80 \%$ & $2.40 \%$ & $-2.4 \%$ & $11.7 \%$ & $-3.6 \%$ & $8.8 \%$ & $59.9 \%$ & $0.6 \%$ & $14.8 \%$ & $87.2 \%$ \\
\hline
\end{tabular}




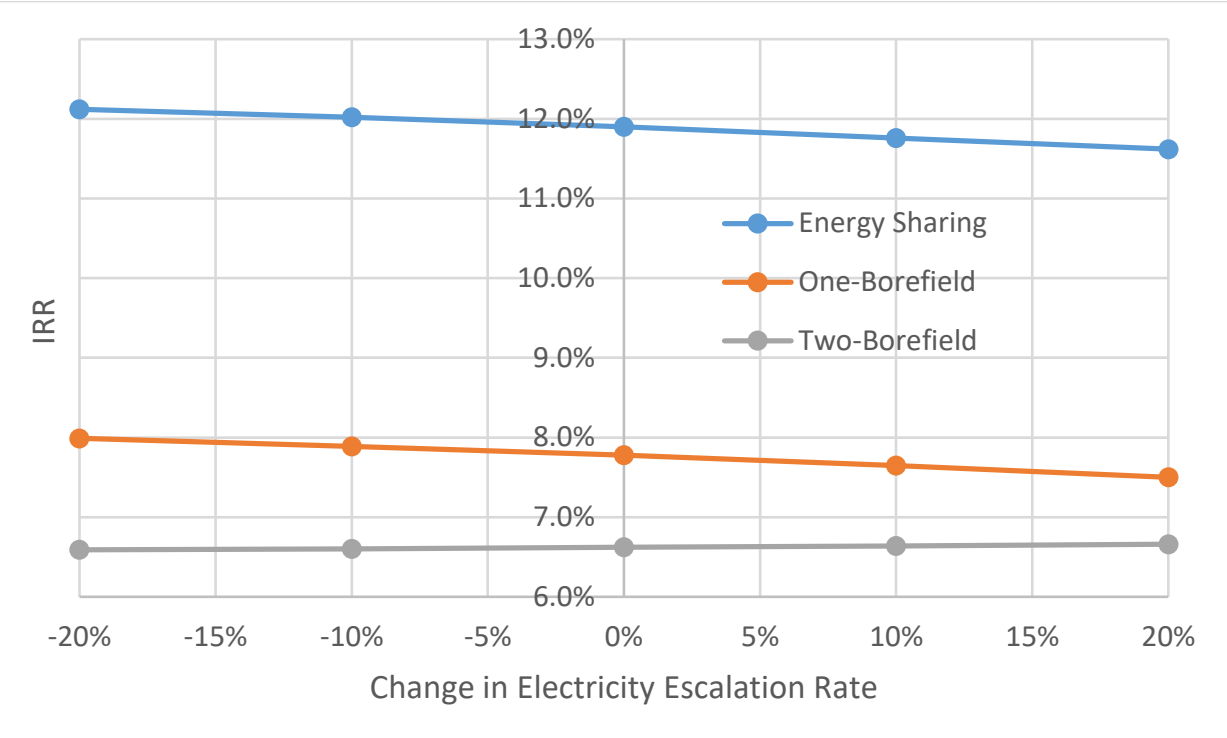

Figure 57: 30-year after-tax IRR for each scenario, testing the sensitivity of changing the electricity escalation rates by $-20,-10,0,10$ and $20 \%$

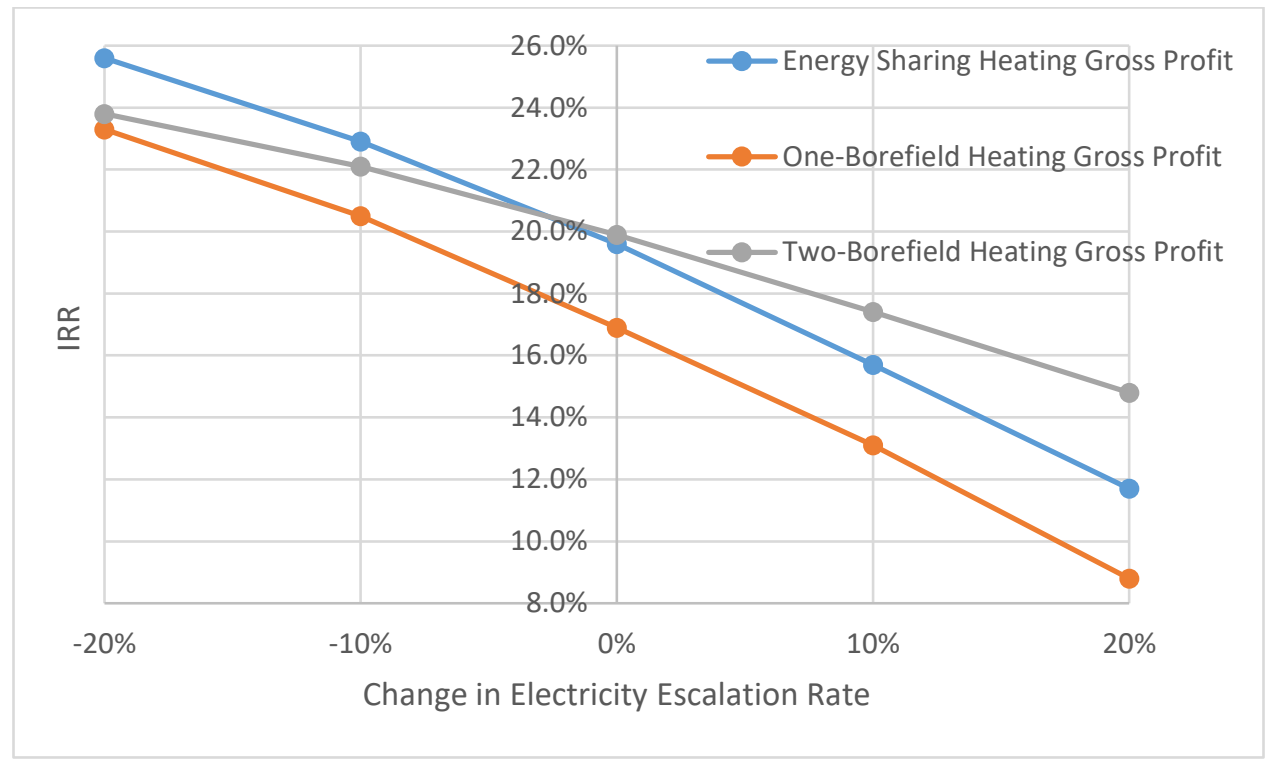

Figure 58: Change in heating gross profit as a result of the electricity escalation rate sensitivity analysis

Similar to the sensitivity of the change in carbon tax escalation rate, the change in electricity escalation rate is more pronounced in scenarios with lower gross profit margins. The sensitivity of electricity escalation is lower than that of carbon tax because electricity is used in 
both the avoided cost and the proposed case, making them partially cancel each other out, whereas natural gas is not use in the proposed CEN.

Overall, the sensitivity analysis of the financial model has shown that the main project risk is in an inaccurate prediction of capital costs. Present energy rates were not tested because they are known for a given area and the analysis shows that changes in carbon tax and electricity escalation are not overly sensitive variables.

\subsection{Sensitivity of Data Centre Size}

The sensitivity of the project to different data centre sizes is important to test for two reasons. First, many data centres leave extra space to expand their IT capacity in the future, directly affecting the cooling load. This can make the cooling capacity of a given data centre difficult to predict. Second, the financial performance of a data centre heat recovery project increases when larger data centres are connected. This effect should be tested to determine the minimum threshold for project implementation. The peak data centre cooling load was changed from $4000 \mathrm{~kW}$ to 3333 , 3636,4400 and $4800 \mathrm{~kW}$. The heating capacity of the MURBs was changed by 10 and $20 \%$ to keep the same optimized ratio of cooling load to heating load. The cost of equipment was also changed to reflect the 10 and $20 \%$ changes in capacity. Table 26 and Figure 59 show the results of this analysis.

Table 26: Summarization of results from the data centre size sensitivity analysis, showing the change in IRR and any other variables which changed during the analysis

\begin{tabular}{|c|c|c|c|}
\hline & Energy Sharing & One-Borefield & Two-Borefield \\
\hline $\begin{array}{c}\text { Data Centre Peak } \\
\text { Cooling }\end{array}$ & \% Change in IRR & \% Change in IRR & \% Change in IRR \\
\hline $3333 \mathrm{~kW}$ & $-13.6 \%$ & $-12.1 \%$ & $-8.9 \%$ \\
\hline $3636 \mathrm{~kW}$ & $-7.2 \%$ & $-6.3 \%$ & $-4.5 \%$ \\
\hline $4000 \mathrm{~kW}$ & $0.0 \%$ & $0.0 \%$ & $0.0 \%$ \\
\hline $4400 \mathrm{~kW}$ & $7.6 \%$ & $5.9 \%$ & $4.5 \%$ \\
\hline $4800 \mathrm{~kW}$ & $14.9 \%$ & $11.3 \%$ & $8.3 \%$ \\
\hline
\end{tabular}




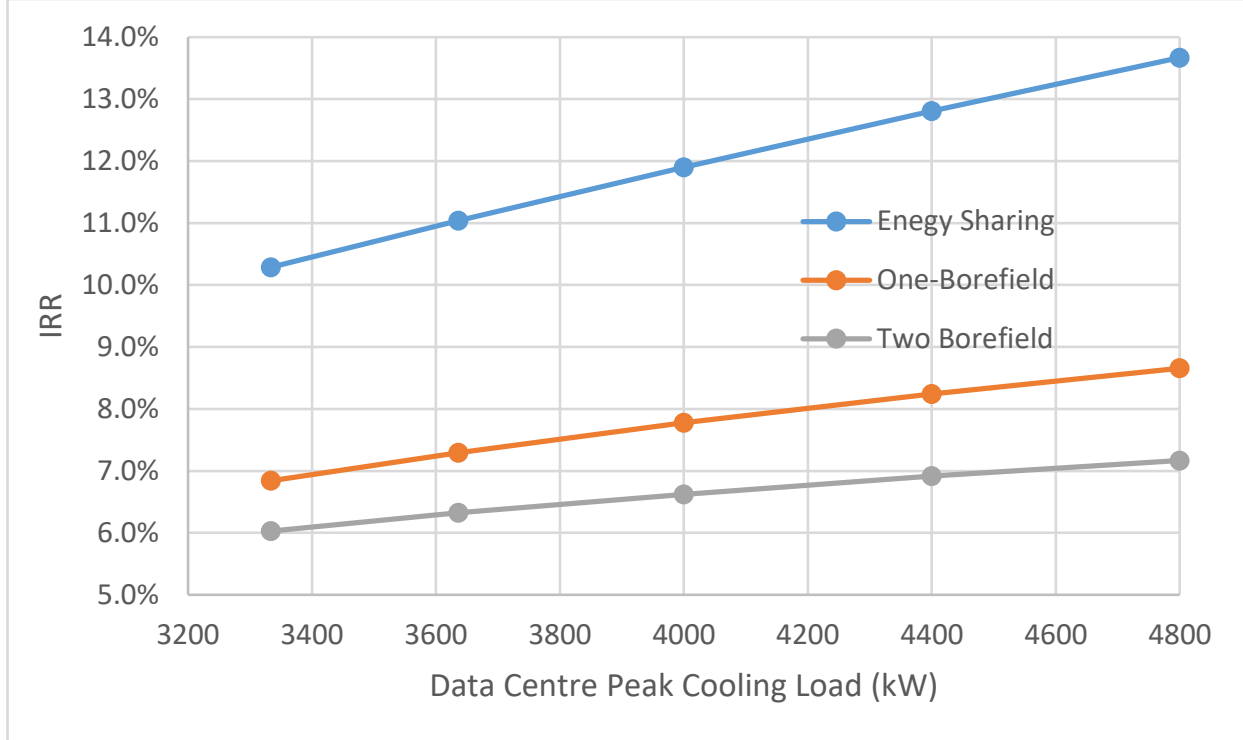

Figure 59: 30-year after-tax IRR for each scenario, testing the sensitivity of a 3333, 3636, 4000,4400 and $4800 \mathrm{~kW}$ data centre peak cooling load

Data centre size had the largest effect on the Energy Sharing System, as it has the largest percentage of costs that do not change with capacity (such as retrofit costs and district piping costs). The two geo-exchange systems had smaller impacts because of the large borefield capital cost changing by 10 and $20 \%$ to simulate the scenario of a different data centre size. The minimum data centre peak cooling load to allow each scenario to meet an $8 \%$ IRR was $2500 \mathrm{~kW}, 4200 \mathrm{~kW}$ and $6800 \mathrm{~kW}$ for the Energy Sharing, One- and Two-Borefield Systems respectively.

\subsection{Sensitivity of Project to other Cities}

\subsubsection{Montreal}

Montreal has 33 data centres and is a good candidate for this project because of the abundant, inexpensive, clean electricity [78]. Montreal has many buildings that are heated via electric resistance heaters, which already result in very low GHG intensity. This case will assume that the MURBs connected in this CEN are heated with natural gas boilers, because natural gas still results in $37 \%$ of building energy consumption in the commercial and institutional sector [79]. Table 27 shows the parameters that were changed to best reflect Montreal's project conditions. 
Table 27: Parameters changed for Montreal sensitivity analysis

\begin{tabular}{|l|c|c|}
\hline & Montreal & Toronto Reference \\
\hline Natural Gas Price & $\$ 0.3135 / \mathrm{m}^{3}[80]$ & $\$ 0.31 / \mathrm{m}^{3}$ \\
\hline Electricity Price & $\$ 0.0797 / \mathrm{kWh}[75]$ & $\$ 0.15 / \mathrm{kWh}$ \\
\hline Ground Temperature & $10^{\circ} \mathrm{C}[81]$ & $10^{\circ} \mathrm{C}$ \\
\hline
\end{tabular}

Table 28 shows the results of the Montreal test case. Since the ground temperature is the same as in Toronto, only the energy prices changed to be lower for electricity and nearly the same for natural gas, resulting in a financial improvement in all scenarios. As was the case in the analyses of carbon tax and electricity rate escalation, the scenario with the lowest gross profit margin had the largest change in IRR.

Table 28: Results from Montreal sensitivity analysis

\begin{tabular}{|l|c|c|}
\hline \multirow{2}{*}{\multicolumn{1}{|c|}{ Scenario }} & \multicolumn{2}{|c|}{ Montreal } \\
\cline { 2 - 3 } & 30-year, after tax IRR before funding & Change in IRR \\
\hline Energy Sharing & $13.9 \%$ & $16.8 \%$ \\
\hline One-Borefield & $11.0 \%$ & $41.7 \%$ \\
\hline Two-Borefield & $7.8 \%$ & $17.2 \%$ \\
\hline
\end{tabular}

\subsubsection{Winnipeg}

Winnipeg contains six data centres [78]. The cold ground temperature makes it an interesting test case for the two geo-exchange scenarios. Table 29 shows the parameters that were changed to best reflect Winnipeg's project conditions.

Table 29: Parameters changed for Montreal sensitivity analysis

\begin{tabular}{|l|c|c|}
\hline & Winnipeg & Toronto Reference \\
\hline Natural Gas Price & $\$ 0.1763 / \mathrm{m}^{3}[82]$ & $\$ 0.31 / \mathrm{m}^{3}$ \\
\hline Electricity Price & $\$ 0.0658 / \mathrm{kWh}[75]$ & $\$ 0.15 / \mathrm{kWh}$ \\
\hline Ground Temperature & $6.5^{\circ} \mathrm{C}[83]$ & $10^{\circ} \mathrm{C}$ \\
\hline
\end{tabular}

Table 30 shows the results of the Winnipeg test case. Although Winnipeg's electricity rate and natural gas rate are $56 \%$ and $43 \%$ lower than Toronto's, respectively, the financial outcome is still negative. This is because natural gas is only used in the avoided case, so a lower natural gas rate directly reduces the heating revenue generated for the project. Electricity is used in both the 
avoided and proposed case, which means a lower electricity rate does little to improve the IRR. The cold ground temperature in Winnipeg required an increase of 75 boreholes in the OneBorefield System and a reduction of 140 boreholes in the cold borefield of the Two-Borefield System. The cold ground was promising for the Two-Borefield System, but a location which has cold ground and higher natural gas prices needs to be found.

Table 30: Results from Winnipeg sensitivity analysis

\begin{tabular}{|l|c|c|}
\hline \multirow{2}{*}{\multicolumn{1}{|c|}{ Scenario }} & \multicolumn{2}{|c|}{ Winnipeg } \\
\cline { 2 - 3 } & 30-year, after tax IRR before funding & Change in IRR \\
\hline Energy Sharing & $8.9 \%$ & $-25.3 \%$ \\
\hline One-Borefield & $5.7 \%$ & $-26.3 \%$ \\
\hline Two-Borefield & $5.6 \%$ & $-15.0 \%$ \\
\hline
\end{tabular}

\subsubsection{New York City}

New York City contains 52 data centres and 755 buildings over $100 \mathrm{~m}$ (approximately 25 storeys), making it a prime candidate for this project [84] [85]. Table 31 shows the parameters that were changed to best reflect New York City's project conditions.

Table 31: Parameters changed for New York City sensitivity analysis

\begin{tabular}{|l|c|c|}
\hline & New York City & Toronto Reference \\
\hline Natural Gas Price & $\$ 0.356 / \mathrm{m}^{3}[86]$ & $\$ 0.31 / \mathrm{m}^{3}$ \\
\hline Electricity Price & $\$ 0.226 / \mathrm{kWh}[75]$ & $\$ 0.15 / \mathrm{kWh}$ \\
\hline Ground Temperature & $12^{\circ} \mathrm{C}[47]$ & $10^{\circ} \mathrm{C}$ \\
\hline
\end{tabular}

Table 32 shows the results of the New York City test case. Both natural gas and electricity are expensive in New York City, compared to the rest of the United States and Toronto. The Energy Sharing System's returns nearly stayed the same because it used a minimal amount of electricity because of efficient heat pump operation. The One-Borefield System experienced a significant drop in returns despite requiring 30 less boreholes because of the larger electricity use. Less boreholes were required, as it was more difficult for the fluid temperature entering the heat pump in heating season to be below $-1.1^{\circ} \mathrm{C}$, due to the increased undisturbed ground temperature 
of $12^{\circ} \mathrm{C}$. The Two-Borefield System experienced the same reduction in IRR as the One-Borefield System despite requiring 130 more boreholes because of the Two-Borefield System's minimal electricity use.

Table 32: Results from New York City sensitivity analysis

\begin{tabular}{|l|c|c|}
\hline \multirow{2}{*}{\multicolumn{1}{|c|}{ Scenario }} & \multicolumn{2}{|c|}{ New York City } \\
\cline { 2 - 3 } & 30-year, after tax IRR before funding & Change in IRR \\
\hline Energy Sharing & $11.6 \%$ & $-2.2 \%$ \\
\hline One-Borefield & $6.1 \%$ & $-21.6 \%$ \\
\hline Two-Borefield & $5.6 \%$ & $-15.7 \%$ \\
\hline
\end{tabular}

\subsubsection{Chicago}

Chicago has 83 data centres and 319 buildings over $100 \mathrm{~m}$ (approximately 25 storeys), making it a prime candidate for this project [87] [85]. Table 33 shows the parameters that were changed to best reflect Chicago's project conditions.

Table 33: Parameters changed for Chicago sensitivity analysis

\begin{tabular}{|l|c|c|}
\hline & Chicago & Toronto Reference \\
\hline Natural Gas Price & $\$ 0.287 / \mathrm{m}^{3}[88]$ & $\$ 0.31 / \mathrm{m}^{3}$ \\
\hline Electricity Price & $\$ 0.0894 / \mathrm{kWh}[75]$ & $\$ 0.15 / \mathrm{kWh}$ \\
\hline Ground Temperature & $12^{\circ} \mathrm{C}[47]$ & $10^{\circ} \mathrm{C}$ \\
\hline
\end{tabular}

Table 34 shows the results of the Chicago test case. Chicago's undisturbed ground temperature was the same as New York City's and thus, the geo-exchange scenarios saw the same decrease and increase in boreholes. Chicago's low electricity rates resulted in the largest benefit for the One-Borefield System because it used the most electricity and also required less boreholes.

Table 34: Results from Chicago sensitivity analysis

\begin{tabular}{|l|c|c|}
\hline \multirow{2}{*}{\multicolumn{1}{|c|}{ Scenario }} & \multicolumn{2}{|c|}{ Chicago } \\
\cline { 2 - 3 } Energy Sharing & 30-year, after tax IRR before funding & Change in IRR \\
\hline One-Borefield & $12.6 \%$ & $6.2 \%$ \\
\hline Two-Borefield & $10.2 \%$ & $31.3 \%$ \\
\hline
\end{tabular}




\subsubsection{Vancouver}

Vancouver contains 21 data centres and its geographic location on the West Coast of North America has not been tested through the other four cities [78]. Table 35 shows the parameters that were changed to best reflect Vancouver's project conditions.

Table 35: Parameters changed for Vancouver sensitivity analysis

\begin{tabular}{|l|c|c|}
\hline & Vancouver & Toronto Reference \\
\hline Natural Gas Price & $\$ 0.214 / \mathrm{m}^{3}[89]$ & $\$ 0.31 / \mathrm{m}^{3}$ \\
\hline Electricity Price & $\$ 0.0872 / \mathrm{kWh}[75]$ & $\$ 0.15 / \mathrm{kWh}$ \\
\hline Ground Temperature & $13^{\circ} \mathrm{C}[81]$ & $10^{\circ} \mathrm{C}$ \\
\hline
\end{tabular}

Table 36 shows the results of the Vancouver test case. Similar to Winnipeg, Vancouver has relatively low natural gas and electricity rates, which resulted in lower returns because of the natural gas rate variable being more sensitive. Similar to the Chicago scenario, the One-Borefield System case had the smallest reduction in IRR and the Two-Borefield System had the largest reduction in IRR because of the $13^{\circ} \mathrm{C}$ ground temperature.

Table 36: Results from Vancouver sensitivity analysis

\begin{tabular}{|l|c|c|}
\hline \multirow{2}{*}{\multicolumn{1}{|c|}{ Scenario }} & \multicolumn{2}{|c|}{ Vancouver } \\
\cline { 2 - 3 } & 30-year, after tax IRR before funding & Change in IRR \\
\hline Energy Sharing & $9.8 \%$ & $-17.4 \%$ \\
\hline One-Borefield & $7.7 \%$ & $-1.4 \%$ \\
\hline Two-Borefield & $5.1 \%$ & $-23.1 \%$ \\
\hline
\end{tabular}

\subsection{Chapter Conclusions}

The city sensitivity analysis showed that Montreal and Chicago produced higher returns than Toronto, and would be ideal candidates for this project because of their common element of relatively low electricity prices and relatively high natural gas prices. The analysis for Winnipeg showed that even with cold undisturbed ground temperatures, the returns for the Two-Borefield System would not be adequate if natural gas prices are low. An ideal candidate for the Two- 
Borefield System would be the Scandinavian region, where natural gas prices are very high and undisturbed ground temperatures are similar to Winnipeg's.

The analysis of data centre size demonstrated that the project will have significantly higher returns if data centres with peak cooling loads larger than $4 \mathrm{MW}$ can be found, while also maintaining the ideal ratio of cooling to heating by finding enough surrounding buildings to add to more than $110,000 \mathrm{~m}^{2}$ of building area. That same analysis found that the minimum data centre peak cooling load for the most profitable (energy sharing) scenario to be financially viable was $2500 \mathrm{~kW}$. Additional considerations for this project are to ensure heating supply temperatures are low, although even a weighted average heating supply temperature of $45^{\circ} \mathrm{C}$ produced high returns in the Energy Sharing System. The Two-Borefield System cannot have a data centre chilled water supply temperature lower than $10^{\circ} \mathrm{C}$, and would significantly benefit from higher chilled water supply temperatures.

\subsection{Chapter Summary}

Sensitivity of Energy Variables

- The heating water supply temperature was the most sensitive energy variable, changing the IRR by a factor of $7-14 \%$, with a $6^{\circ} \mathrm{C}$ change in supply temperature.

- The chilled water supply temperature was the most sensitive variable for the Two-Borefield System, lowering the IRR by a factor of $43 \%$ at $8^{\circ} \mathrm{C}$ and raising it by a factor of $13 \%$ at $12^{\circ} \mathrm{C}$.

Sensitivity of Financial Variables

- The capital cost was the most sensitive financial variable, changing the IRR by a factor of $15-22 \%$, when varying the capital cost by $20 \%$.

\section{Sensitivity of Data Centre Size}

- The Energy Sharing System was the most sensitive to changes in data centre peak cooling load, changing the IRR by around $14 \%$ with a change in peak cooling load of $20 \%$. 
- The minimum data centre peak cooling load for the Energy Sharing System was found to be $2500 \mathrm{~kW}$.

\section{Sensitivity of Project to Other Cities}

- The project had the highest returns in Montreal, where the IRR improved by factors of 17$42 \%$.

- Chicago also had high returns for the Energy Sharing and One-Borefield System, but lower returns for the Two-Borefield System. 


\section{CHAPTER V - Conclusions}

The scope of this thesis is to determine the optimum way to create a $\mathrm{CEN}$, serving a data centre and several MURBs. The first scenario demonstrated the simplicity of only energy sharing, the second scenario layered in standard geo-exchange as an energy source and the third scenario was a unique approach to achieving free cooling, tailored to the high data centre chilled water supply temperature. Scenarios 1 and 2 were simulated in GLD, while Scenario 3 was simulated in TRNSYS. The simulation results were then used in a custom Microsoft Excel model which compared each scenario on a financial basis. Each scenario's GHG emissions savings were also calculated to contextualize their benefit. The following are significant findings and conclusions from the analysis and scenario evaluation.

\subsection{Summary}

The following is a summary of the significant findings and conclusions determined from the analyses conducted in Chapter 3 and Chapter 4:

\subsubsection{Comparison of Three Different Energy Sharing Systems}

\section{Community Energy Network}

- The optimal MURB area that should be connected to a $4 \mathrm{MW}$ cooling load data centre is $110,000 \mathrm{~m}^{2}$ in Toronto, Canada.

- The project considers that data centres should receive a $25 \%$ reduction in cooling costs, so that they are enticed to participate in the project.

\section{Energy Sharing System}

- The scenario of only energy sharing was the most profitable, with a $11.9 \% 30$-year aftertax IRR. 
- The scenario resulted in the most efficient operation, achieving a 4.3 COP for heating and free cooling.

- This scenario would reduce the MURBs' annual heating related GHG emissions by 2220 tonnes $(53 \%)$ and reduce the data centre's annual cooling related GHG emissions by 67 tonnes $(51 \%)$.

\section{$\underline{\text { One-Borefield System }}$}

- This scenario performed slightly better than the Two-Borefield System because of its significantly lower capital cost.

- $\quad$ This scenario achieved an 7.8\% 30-year after-tax IRR.

- This scenario would reduce the MURBs' annual heating related GHG emissions by 3306 tonnes $(79 \%)$ and reduce the data centre's annual cooling related GHG emissions by 74 tonnes $(56 \%)$.

$\underline{\text { Two-Borefield System }}$

- This scenario required $15 \%$ of the total capital cost in funding to achieve an $8 \%$ 30-year after-tax IRR.

- This scenario would reduce the MURBs' annual heating related GHG emissions by 3522 tonnes (84\%) and reduce the data centre's annual cooling related GHG emissions by 108 tonnes $(82 \%)$.

- If carbon tax increased by an additional \$14/tonne this scenario would be financially viable.

\subsubsection{Sensitivity Analysis}

Sensitivity of Energy Variables

- The heating water supply temperature was the most sensitive energy variable, changing the IRR by a factor of $7-14 \%$, with a $6^{\circ} \mathrm{C}$ change in supply temperature. 
- The chilled water supply temperature was the most sensitive variable for the Two-Borefield System, lowering the IRR by a factor of $43 \%$ at $8^{\circ} \mathrm{C}$ and raising it by a factor of $13 \%$ at $12^{\circ} \mathrm{C}$.

\section{$\underline{\text { Sensitivity of Financial Variables }}$}

- The capital cost was the most sensitive financial variable, changing the IRR by a factor of $15-22 \%$, when varying the capital cost by $20 \%$.

\section{Sensitivity of Data Centre Size}

- The energy sharing system was the most sensitive to changes in data centre peak cooling load, changing the IRR by around $14 \%$ with a change in peak cooling load of $20 \%$.

- The minimum data centre peak cooling load for the energy sharing system was found to be $2500 \mathrm{~kW}$.

Sensitivity of Project to Other Cities

- The project had the highest returns in Montreal, where the IRR improved by factors of 17$42 \%$.

- Chicago also had high returns for the Energy Sharing and One-Borefield Systems, but lower returns for the Two-Borefield System.

\subsection{Recommendations}

This study demonstrated the financial and carbon benefit an existing community with a data centre can have if a district energy approach is applied. The Energy Sharing System (Scenario 1) is the recommended system because of its high returns, its simplicity and the fact that it will financially improve at larger scales because $75 \%$ of the capital cost is fixed.

The sensitivity analysis of cities showed that the best cities for implementation of this project were Montreal and Chicago, although the Energy Sharing System has an adequate IRR for implementation in all the five additional cities that were studied: Montreal, Chicago, New York City, Winnipeg and Vancouver. The selected cities represent different climates and energy 
markets, so it can be concluded that the project could be implemented in any city which has a significant heating requirement in North America. The analysis also showed that the Energy Sharing System could be implemented in Toronto even if the data centre peak cooling load is as small as $2500 \mathrm{~kW}$.

Further research could be of benefit. An experimental analysis could be conducted for the cold borefield of the Two-Borefield System. The experiment would determine if local ground freezing significantly improves thermal conductivity, and thereby improves the financial outcome of the Two-Borefield System. An alternative to the experiment could be a finite element model of the borefield, which could capture the change in ground thermal conductivity during freezing conditions. 


\section{References}

[1] Science Based Target Initiative, "Science-based Target Setting Manual," 6 March 2017. [Online]. Available: http://sciencebasedtargets.org/wp-content/uploads/2016/10/SBTManual-Draft.pdf.

[2] J. Koomey, "Growth in data center electricity use 2005 to 2010," New York Times, 2011.

[3] T. Brunschwiler, B. Smith, E. Ruetsche and B. Michel, "Toward zero-emission data centers through direct reuse of thermal energy," IBM Journal of Research and Development, vol. 53, no. 3, pp. 11:1 - 11:13, 2009.

[4] J. Velkova, "Data that warms: Waste heat, infrastructural convergence and the computation traffic commodity," Big Data and Society, pp. 1-10, 2016.

[5] The Data Center Journal, "Dynamic Global Data Centre Market to Surge Through 2018," 1 February 2018. [Online]. Available: http://www.datacenterjournal.com/dynamic-globaldata-center-market-surge-2018/.

[6] N. Rasmussen, "Calculating Total Cooling Requirements for Data Centers," Schneider Electric , 2011.

[7] ASHRAE, "2011 Thermal Guidelines for Data Processing Environments-Expanded Data Center Classes and Usage Guidance," American Society of Heating, Refrigerating and Air-Conditioning Engineers, Inc., 2011.

[8] Stulz, "Free Cooling for Data Centers," Stulz, 2015.

[9] Hewlett-Packard, "Applying 2011 ASHRAE data center guidelines to HP ProLiant-based facilities," Hewlett-Packard, 2012.

[10] K. Ebrahimi, J. G. F. and A. S. Fleischer, "A review of data center cooling technology, operating conditions and the corresponding low-grade waste heat recovery," Renewable and Sustainable Energy Reviews, pp. 623-638, 2014.

[11] V. Depoorter, E. Oró and J. Salom, "The location as an energy efficiency and renewable energy supply measure for data centres in Europe," Applied Energy, vol. 140, pp. 338-349, 2015.

[12] Raging Wire, Synapsense, York, Silicon Valley Leadership Group, "Maximizing Cooling Efficiency in a Concurrently Maintainable and Fault Tolerant Data Center," Mission Critical Magazine, 2012.

[13] J. Sasser, "A Look at Data Center Cooling Technologies," Uptime Institute , 2014. [Online]. Available: https://journal.uptimeinstitute.com/a-look-at-data-center-coolingtechnologies/. [Accessed 27 April 2017].

[14] Baltimore Air Coil, "Cooling Towers," 2015. [Online]. Available: http://www.baltimoreaircoil.com/english/resource-library/file/823. [Accessed 23 April 2017].

[15] HP, "Model-Based Approach for Optimizing a Data Center Centralized," 14 April 2006. [Online]. Available: http://www.hpl.hp.com/techreports/2006/HPL-2006-67.pdf. [Accessed 29 October 2016].

[16] S. Greenberg, E. Mills, B. Tschudi and P. Rumsey, "Best Practices for Data Centers: Lessons Learned from Benchmarking 22 Data Centres," ACEEE Summer Study on Energy Efficiency in Buildings, pp. 76-87, 2006. 
[17] R. Loflin, "Is "Free Cooling" Really Free," FacilitiesNet, 2016. [Online]. Available: http://www.facilitiesnet.com/hvac/contributed/Is-quotFree-Coolingquot-Really-Free-37475. [Accessed 25 April 2017].

[18] ASHRAE, "ASHRAE Standard 90.1-2007 Energy Standard for Buildings Except LowRise Residential Buildings," ASHRAE, 2009.

[19] European Association for Storage of Energy, "Thermal Hot Water Storage," March 2016. [Online]. Available: http://ease-storage.eu/wpcontent/uploads/2016/03/EASE_TD_HotWater.pdf. [Accessed 23 April 2017].

[20] M. Napolitan, "Getting the Most Out of Your Commercial Condensing Boiler," Cx Associates , 11 April 2012. [Online]. Available: https://buildingenergy.cxassociates.com/2012/04/getting-the-most-out-of-your-commercial-condensing-boiler/. [Accessed 23 April 2017].

[21] Green Match, "Condensing vs Non-Condensing Boilers," 28 March`2017. [Online]. Available: http://www.greenmatch.co.uk/blog/2015/10/condensing-vs-non-condensingboilers. [Accessed October 2015].

[22] Pacific Northwest National Labortory , "ANSI/ASHRAE/IES Standard 90.1-2013 Determination of Energy Savings: Quantitative Analysis," U.S. Department of Energy, 2014.

[23] Baltimore Air Coil, "Series V Closed Circuit Cooling Towers," 2013. [Online]. Available: http://www.baltimoreaircoil.com/english/resource-library/file/546. [Accessed 24 April 2017].

[24] R. George, "Hot Water System Temperatures and the Code," Plumbing Engineer, October 2014. [Online]. Available: http://www.plumbingengineer.com/content/hot-water-systemtemperatures-and-code. [Accessed 27 April 2017].

[25] Halton Region, "Legionella," Halton Region, 2017. [Online]. Available: http://www.halton.ca/cms/One.aspx?portalId=8310\&pageId=9673. [Accessed 27 April 2017].

[26] Government of Ontario, "O. Reg. 23/04: Building Code," Government of Ontario, 18 February 2004. [Online]. Available: https://www.ontario.ca/laws/regulation/r04023. [Accessed 27 April 2017].

[27] JMP, "Domestic Hot Water Recirculation Part 4: Pump Sizing Example," Square Space, 18 August 2014. [Online]. Available: http://jmpcoblog.com/hvac-blog/domestic-hotwater-recirculation-part-4-pump-sizing-example. [Accessed 27 April 2017].

[28] C. Binkley, M. Touchie and K. Pressnail, "Energy Consumption Trends of Multi-Unit Residential Buildings in the City of Toronto," Toronto Atmospheric Fund, Toronto, 2013.

[29] M. Ghajarkhosravi, "Utility Benchmarking And Potential Savings of Multi-Unit Residential Buildings (MURBs) In Toronto," Toronto, 2013.

[30] C. Gemmill, Interviewee, Director, Engineering. [Interview]. March 2017.

[31] International District Energy Association , "IDEA Report: The District Energy Industry," International District Energy Association, 2005.

[32] M. Spurr, "Getting Into Hot Water: Costs and Benefits," June 2012. [Online]. Available: http://www.districtenergy.org/assets/pdfs/03AnnualConference/Monday-B/B5- 
1SPURRFVBGetting-into-Hot-Water-IDEA-June-2012-FINAL-2.pdf. [Accessed 25 April 2017].

[33] Thermenex, "What We Do," Thermenex, 2017. [Online]. Available: https://thermenex.com/about/. [Accessed 25 April 2017].

[34] J. Weston, Interviewee, President and CEO. [Interview]. 8 March 2017.

[35] Thermenex , "Thermenex - Aquatic Complexes," March 2017. [Online]. Available: https://2khdwl2lx3wy1py4uy1bg4qg-wpengine.netdna-ssl.com/wpcontent/uploads/2017/03/Thermenex-Aquatic-Complexes-Energy-Comparison.pdf. [Accessed 25 April 2017].

[36] M. Vargončík and M. Marci, "Air-Source Heat Pumps," Technical University of Košice, 2005.

[37] R. Hubbard, "Water-to-Water Heat Pumps," ASHRAE Journal, vol. 51, no. 1, pp. 28-35, 2009.

[38] T. H. Durkin and K. E. Cecil, "Geothermal Central System," ASHRAE Journal , 2007.

[39] H. ACÜL, "Dry Cooler Free Cooling Applications in Cold Water Air Conditioning and Process Cooling," Friterm, 2008.

[40] Dry Coolers Inc, "Solanus Series Quench Oil Coolers," Dry Coolers Inc, 2017. [Online]. Available: http://drycoolers.com/support/brochures/solanus-series-quench-oil-coolers. [Accessed 27 April 2017].

[41] G. Shymko, "Earth's exchange: ground source heat pumps," Canadian Consulting Engineer, 1 August 2000. [Online]. Available:

http://www.canadianconsultingengineer.com/features/earth-s-exchange-ground-sourceheat-pumps/. [Accessed 27 April 2017].

[42] Canadian GeoExchange Coalition, "How GeoExchange Systems Work?," 2016. [Online]. Available: http://www.geo-exchange.ca/en/geoexchange_how_it_works_p49.php. [Accessed 10 November 2016].

[43] G. Florides and S. Kalogirou, "Annual Ground Temperature Measurements at Various Depths," Higher Technical Institute , 2005.

[44] G. Florides and S. Kalogirou, "Ground heat exchangers - A review of systems, models and applications," Renewable Energy, vol. 32, no. 15, p. 2461-2478, 2007.

[45] S. Reitsma, Interviewee, CEO, Owner Geosource. [Interview]. 31 March 2017.

[46] Government of Ontario, "Geology Ontario," 2008. [Online]. Available: http://www.geologyontario.mndmf.gov.on.ca/mndmfiles/pub/data/imaging/M2544/M2544 .pdf. [Accessed 25 April 2017].

[47] ASHRAE, "ASHRAE Handbook- HVAC Applications: Geothermal Energy," ASHRAE, 2011.

[48] F. R. Rad, "An integrated model for designing a solar community heating system with borehole thermal storage," Energy for Sustainable Development, no. 36, pp. 6-15, 2017.

[49] Y. Man, H. Yang and J. Wang, "Study on Hybrid Ground-Coupled Heat Pump System for Air-Conditioning in Hot-Weather Areas Like Hong Kong," Applied Energy, vol. 87, pp. 2826-2833, 2010. 
[50] E. Johanasson, "Optimization of Ground Source," KTH Industrial Engineering and Management, 2012.

[51] G. Davies, G. Maidment and R. Tozer, "Using data centres for combined heating and cooling: An investigation for London," Applied Thermal Engineering, vol. 94, pp. 269304, 2016.

[52] K. Ebrahimi, G. Jones and A. Fleischer, "A review of data center cooling technology, operating conditions and the corresponding low-grade waste heat recovery opportunities," Renewable and Sustainable Energy Reviews, vol. 31, pp. 622-638, 2014.

[53] Open District Heating, "Bahnhof data centre Thule," 2012. [Online]. Available: https://oppenfjarrvarme.fortum.se/?case=bahnhof_thule\&lang=en. [Accessed 30 October 2016].

[54] Open District Heating, "Bahnhof data centre Pionen," 2012. [Online]. Available: https://oppenfjarrvarme.fortum.se/?case=bahnhof_pionen\&lang=en. [Accessed 30 October 2016].

[55] IDEA Industry News, "Update: In Seattle waste heat is being recovered to heat buildings," DistrictEnergy.org, 30 June 2016. [Online]. Available:

http://www.districtenergy.org/blog/2016/06/30/update-in-seattle-recovered-waste-heat-isbeing-used-to-heat-buildings/. [Accessed 27 April 2017].

[56] IDEA Industry News, "District energy system pulls heat from data centers in Westin Building to heat new Amazon buildings," DistrictEnergy.org, 17 November 2015. [Online]. Available: http://www.districtenergy.org/blog/2015/11/17/district-energysystem-pulls-heat-from-data-centers-in-westin-building-to-heat-new-amazon-buildings/. [Accessed 27 April 2017].

[57] Heat Pumps Today, "Finnish City uses Waste Heat from Data Centre for District Heating," Heat Pumps Today, 10 August 2015. [Online]. Available: http://www.heatpumps.media/features/finnish-city-uses-waste-heat-from-data-centre-fordistrict-heating. [Accessed 27 April 2017].

[58] Data Center Dynamics, "DCD at CeBIT: Heat reuse worth more than PUE - Yandex," Data Center Dynamics, 18 March 2015. [Online]. Available:

http://www.datacenterdynamics.com/content-tracks/design-build/dcd-at-cebit-heat-reuseworth-more-than-pue-yandex/93586.fullarticle. [Accessed 27 April 2017].

[59] Open District Heating, "Pilots," 2017. [Online]. Available: https://www.opendistrictheating.com/.

[60] Thermal Dynamics Inc., "Ground Loop Design Version GLD2016," 2016. [Online]. Available: http://www.groundloopdesign.com/2016_commercial.html.

[61] Thermal Energy System Specialists, LLC, "TRNSYS Transient System Simulation Tool," 2017. [Online]. Available: http://www.trnsys.com/.

[62] Canadian Morgatage and Housing Corporation, "Survey of In-Suite Space and Domestic Hot Water Heating Systems in Multi-Residential Buildings," Government of Canada, 2003.

[63] AHRI, "ANSI/AHRI Standard 440 with Addendum 1," Air-Conditioning, Heating, and Refrigeration Institute, 2008.

[64] Bosch, "Bosch Climate 5000 Brushless DC Fan Coil Unit," Bosch, 2014. 
[65] Trane, "Series R Helical Rotary Liquid Chillers," February 2010. [Online]. Available: https://www.trane.com/content/dam/Trane/Commercial/global/productssystems/equipment/chillers/compr-chillers/rlc-prc029-en_02012010.pdf.

[66] Nguyen et al., "An analysis of the factors affecting hybrid ground-source heat pump installation potential in North America," Applied Energy 125, pp. 28-38, 2014.

[67] Canada Mortgage and Housing Corporation, "MULTI-UNIT RESIDENTIAL BUILDINGS Tune-Ups for Energy and Water Efficiency," Goverment of Canada , 2017.

[68] Stulz, "Data Centre Cooling Best Practice," Stulz, 2008.

[69] A. A. Alaica and S. B. Dworkin, "Characterizing the effect of an off-peak ground pre-cool control strategy on hybrid ground source heat pump systems," Energy and Buildings, pp. 46-59, 2017.

[70] J. A. Shonder, J. Thorton and P. J. Hughes, "Selecting the Design Entering Water Temperature for Vertical Geothermal Heat Pumps in Cooling-Dominated Applications," 23 June 2001. [Online]. Available: http://citeseerx.ist.psu.edu/viewdoc/download?doi=10.1.1.498.2829\&rep=rep1\&type=pdf.

[71] Ontario Geothermal Association, "The OGA's Response to Ontario's Long Term Energy Plan," OGA, 2011.

[72] C. Thorn, Interviewee, Director, Community Energy Planning at Enwave Energy Corporation. [Interview]. 1 February 2018.

[73] Bell and Gossett, "Bell and Gossett," 2018. [Online]. Available: http://bellgossett.com/selection-sizing-cad-tools/system-syzer/.

[74] ASHRAE, "ASHRAE 90.1-2010," 2010.

[75] Hydro Quebec, "Comparison of Electricity Prices in Major North American Cities 2017," 1 April 2017. [Online]. Available: http://www.hydroquebec.com/data/documentsdonnees/pdf/comparison-electricity-prices.pdf.

[76] Morrison Hershfield, "Comprehensive Reserve Fund Study TSCC 2350," Toronto, 2014.

[77] Green Ontario Fund, "Guidance Document GreenON Challenge," Green Ontario Fund, 2018.

[78] Data Centre Research, "Colocation Canada," 2018. [Online]. Available: http://www.datacentermap.com/canada/.

[79] Ville de Montreal, "Reduced Dependance on Fossil Fuels in Montreal," 15 June 2016. [Online]. Available:

http://ocpm.qc.ca/sites/ocpm.qc.ca/files/document_consultation/3.1_anglais_ocpm_fossil_ fuels_en_1.pdf.

[80] Energir, "Bill Components," 1 November 2015. [Online]. Available:

https://www.energir.com/ /media/Files/Residentiel/Tarif/Residentiel_D1_facture_an.pdf?1 $\mathrm{a}=\mathrm{en}$.

[81] P. E. Nejad and M. Bernier, "Simulations of a New Double U-tube Borehole Configuration with Solar Heat Injection and Ground Freezing," in eSim, Halifax, 2012.

[82] Manitoba Hydro, "Natural Gas Sales Service - Billed Rate Schedule," 1 May 2018. [Online]. Available: https://www.hydro.mb.ca/accounts_and_services/rates/pdf/billed_rate_schedule.pdf. 
[83] G. P. Williams and L. W. Gold, "Ground temperatures," National Research Council Canada, 1976.

[84] Data Centre Research, "Colocation New York," 2018. [Online]. Available: http://www.datacentermap.com/usa/new-york/new-york/.

[85] Emporis GMBH, "Cities with the most skyscrapers," 2018. [Online]. Available: https://www.emporis.com/statistics/most-skyscraper-cities-worldwide.

[86] U.S. Department of Energy, "New York Price of Natural Gas Sold to Commercial Customers," 30 April 2018. [Online]. Available: https://www.eia.gov/dnav/ng/hist/n3020ny3m.htm.

[87] Data Centre Research, "Colocation Chicago," 2018. [Online]. Available: http://www.datacentermap.com/usa/illinois/chicago/.

[88] U.S. Department of Energy, "Illinois Price of Natural Gas Sold to Commercial Consumers," 30 April 2018. [Online]. Available: https://www.eia.gov/dnav/ng/hist/n3020il3m.htm.

[89] Fortis BC, "Mainland, Vancouver Island and Whistler - Rate 3," 1 January 2018. [Online]. Available: https://www.fortisbc.com/NaturalGas/Business/Rates/Mainland/Pages/LMRate3.aspx. 


\section{Appendix}

\section{Energy Inputs}

Figure 60 was used to calculate the optimal portions of data centre peak cooling load that should be provided by the CEN. This was then used to generate the load profile that was used to determine energy sharing and to feed into the geo-exchange models.

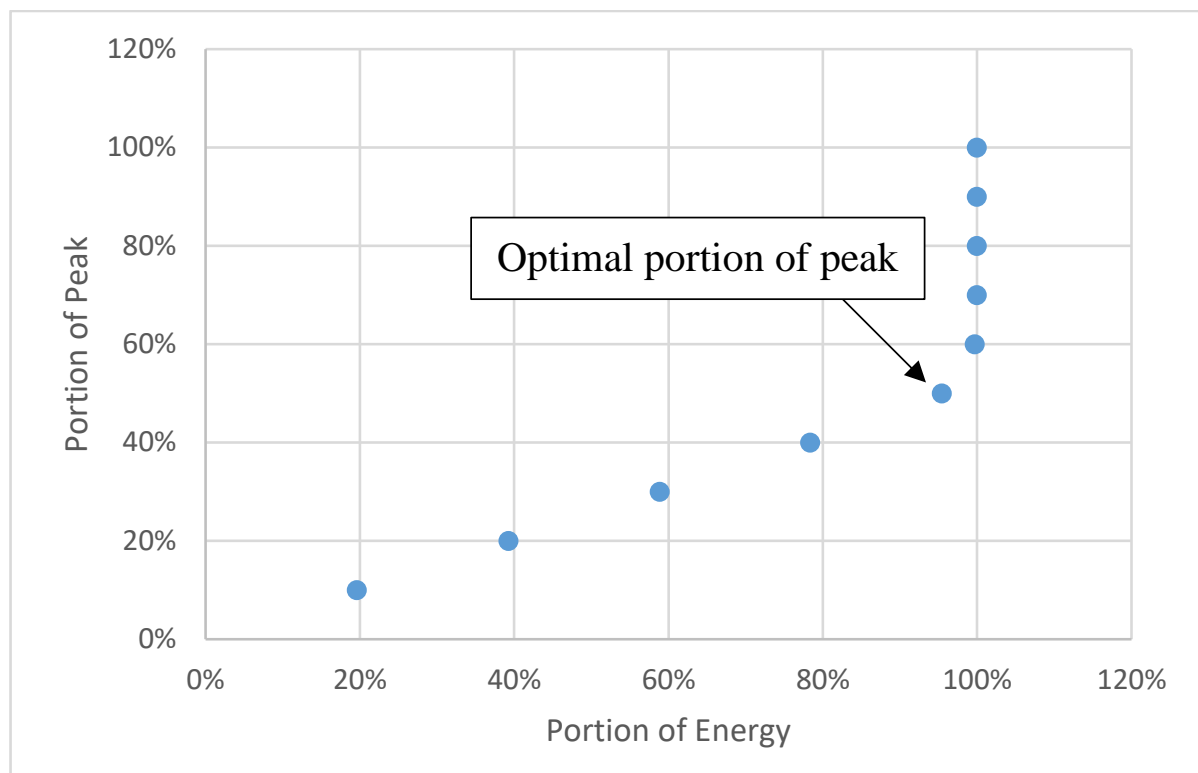

Figure 60: Optimization data centre cooling energy met by the CEN for minimized peak provided by the CEN

Table 37 outlines the energy consumption of equipment which was used in the CEN and also the energy consumption of existing equipment in the proposed cases.

Table 37: Energy consumption breakdown for all equipment in $\mathrm{kWh}$

\begin{tabular}{|l|c|c|c|}
\hline & $\begin{array}{c}\text { Energy } \\
\text { Sharing } \\
(\mathbf{k W h})\end{array}$ & $\begin{array}{c}\text { One- } \\
\text { Borefield } \\
(\mathbf{k W h})\end{array}$ & $\begin{array}{c}\text { Two- } \\
\text { Borefield } \\
(\mathbf{k W h})\end{array}$ \\
\hline Heating from Existing Boilers at MURBs & $10,196,154$ & $4,006,410$ & $4,006,410$ \\
\hline Cooling from Existing Chiller at Data Centre & $1,541,670$ & 140,960 & 140,960 \\
\hline Energy Sharing Heat Pump in Heating & $2,303,502$ & $2,302,499$ & $2,302,499$ \\
\hline Energy Sharing Heat Pump in Cooling & - & - & - \\
\hline Pump for Heating Distribution & 15,866 & 23,678 & 26,171 \\
\hline Pump for Cooling Distribution & 2,999 & 5,745 & 5,745 \\
\hline
\end{tabular}




\begin{tabular}{|l|c|c|c|}
\hline Heat Pump for Geo-exchange in Heating & - & $1,370,504$ & $1,243,344$ \\
\hline Heat Pump for Geo-exchange in Cooling & - & $1,120,527$ & - \\
\hline Pump for Geo-exchange in Heating & - & 23,456 & 23,456 \\
\hline Pump for Geo-exchange in Cooling & - & 78,747 & 3,205 \\
\hline Cooling Tower & - & 228,916 & - \\
\hline Dry Cooler & - & - & 397,453 \\
\hline Dry Cooler Circulation Pump & - & - & 10,472 \\
\hline Total CEN Energy Consumption & $2,322,367$ & $5,154,073$ & $4,012,344$ \\
\hline Total Including CEN and Existing Capacity & $14,060,191$ & $9,301,443$ & $8,159,714$ \\
\hline
\end{tabular}

\section{Financial Model Results}

Figures 66-68 show the cash flows from each energy sharing system's financial model. Capital recovery charges, which were explained as capacity charges in Section 3.6.2 are only used in the One- and Two-Borefield Systems.

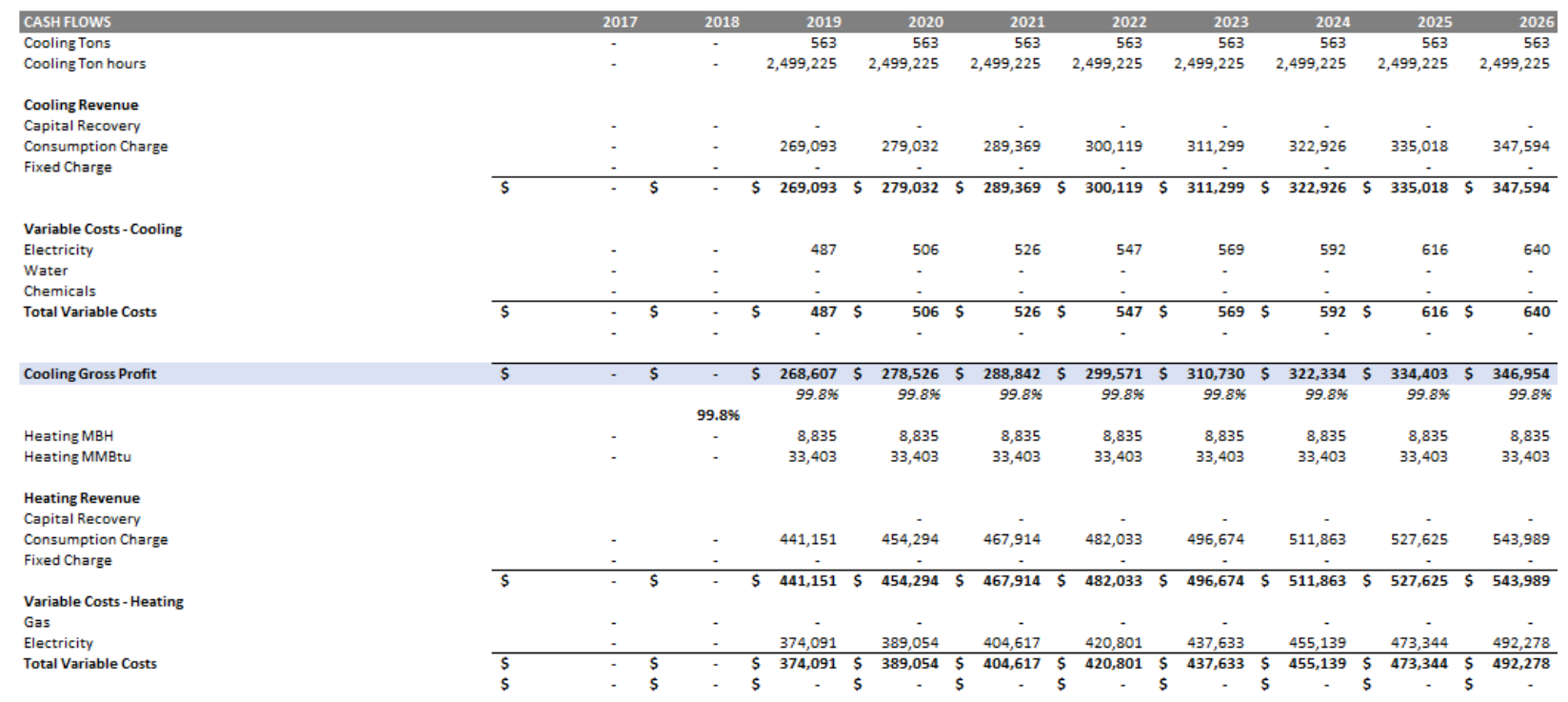




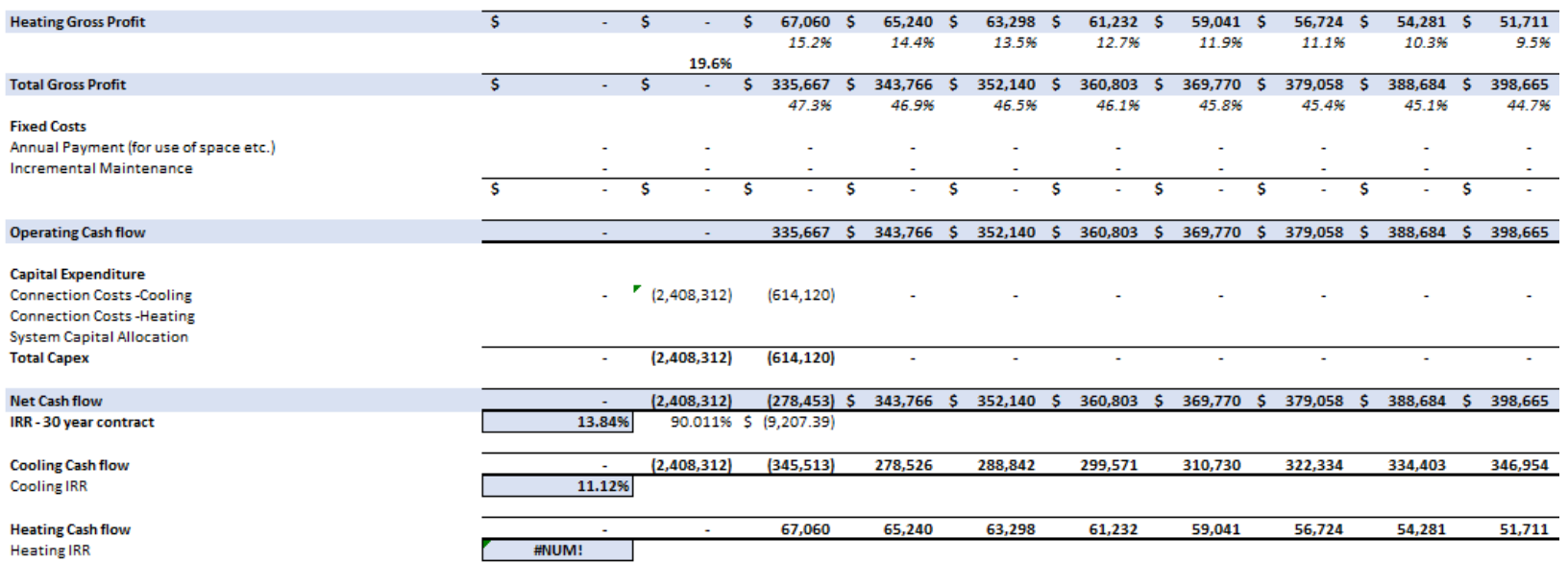

Figure 61: Snapshot of cashflows from the Energy Sharing System financial model in Microsoft Excel

\begin{tabular}{|c|c|c|c|c|c|c|c|c|c|c|c|}
\hline CASH FLOWS & & 2017 & 2018 & 2019 & 2020 & 2021 & 2022 & 2023 & 2024 & 2025 & 2026 \\
\hline Cooling Tons & & - & - & 563 & 563 & 563 & 563 & 563 & 563 & 563 & 563 \\
\hline Cooling Ton hours & & - & - & $4,787,463$ & $4,787,463$ & $4,787,463$ & $4,787,463$ & $4,787,463$ & $4,787,463$ & $4,787,463$ & $4,787,463$ \\
\hline \multicolumn{12}{|l|}{ Cooling Revenue } \\
\hline Capital Recovery & & - & - & 29,297 & 29,883 & 30,481 & 31,090 & 31,712 & 32,346 & 32,993 & 33,653 \\
\hline Consumption Charge & & - & - & 515,469 & 534,508 & 554,309 & 574,901 & 596,317 & 618,590 & 641,754 & 665,844 \\
\hline \multirow[t]{2}{*}{ Fixed Charge } & & - & - & - & - & - & - & - & - & - & - \\
\hline & s & - & - & $\$ 544,766$ & $\$ 564,391$ & $\$ 584,789$ & \$ 605,991 & $\$ 628,029$ & $\$ 650,936$ & \$ 674,747 & \$ 699,497 \\
\hline \multicolumn{12}{|l|}{ Variable Costs-Cooling } \\
\hline Electricity & & - & - & 226,624 & 232,854 & 239,262 & 245,854 & 252,635 & 259,612 & 266,789 & 274,172 \\
\hline Water & & - & - & 9,464 & 9,654 & 9,847 & 10,044 & 10,244 & 10,449 & 10,658 & 10,871 \\
\hline Chemicals & & - & - & 893 & 911 & 929 & 948 & 967 & 986 & 1,006 & 1,026 \\
\hline \multirow[t]{2}{*}{ Total Variable Costs } & $\$$ & $\$$ & - & $\$ 236,981$ & $\$ 243,418$ & $\$ 250,038$ & $\$ 256,846$ & $\$ 263,847$ & $\$ 271,047$ & $\$ 278,453$ & $\$ 286,070$ \\
\hline & & - & - & - & - & - & - & - & - & - & - \\
\hline \multirow[t]{3}{*}{ Cooling Gross Profit } & s & $\$$ & - & \$ 307,785 & $\$ 320,973$ & $\$ 334,751$ & $\$ 349,146$ & $\$ 364,183$ & $\$ 379,889$ & \$ 396,294 & $\$ 413,427$ \\
\hline & & & & $56.5 \%$ & 56.996 & $57.2 \%$ & $57.6 \%$ & $58.0 \%$ & 58.496 & 58.796 & $59.1 \%$ \\
\hline & & & $56.9 \%$ & & & & & & & & \\
\hline Heating MBH & & - & - & 13,321 & 13,321 & 13,321 & 13,321 & 13,321 & 13,321 & 13,321 & 13,321 \\
\hline Heating MMBtu & & - & - & 49,849 & 49,849 & 49,849 & 49,849 & 49,849 & 49,849 & 49,849 & 49,849 \\
\hline \multicolumn{12}{|l|}{ Heating Revenue } \\
\hline Capital Recovery & & & & & 29,970 & 30,569 & 31,180 & 31,804 & 32,440 & 33,089 & 33,751 \\
\hline Consumption Charge & & - & - & 658,346 & 677,960 & 698,285 & 719,355 & 741,205 & 763,871 & 787,394 & 811,815 \\
\hline \multirow[t]{2}{*}{ Fixed Charge } & & - & - & - & - & - & - & - & - & - & - \\
\hline & $\$$ & $\$$ & - & $\$ 658,346$ & $\$ 707,929$ & $\$ 728,854$ & $\$ 750,536$ & $\$ 773,009$ & $\$ 796,312$ & $\$ 820,483$ & $\$ 845,565$ \\
\hline \multicolumn{12}{|l|}{ Variable Costs - Heating } \\
\hline Gas & & - & - & - & - & - & - & - & - & - & - \\
\hline Electricity & & - & - & 597,009 & 620,890 & 645,725 & 671,554 & 698,416 & 726,353 & 755,407 & 785,623 \\
\hline \multirow[t]{2}{*}{ Total Variable Costs } & 5 & - & - & $\$ 597,009$ & $\$ 620,890$ & $\$ 645,725$ & $\$ 671,554$ & $\$ 698,416$ & $\$ 726,353$ & $\$ 755,407$ & $\$ 785,623$ \\
\hline & $\$$ & - & - & $\$$ & $\$$ & $\$$ & $\$$ & $\$$ & $\$$ & $\$$ & $\$$ \\
\hline
\end{tabular}




\begin{tabular}{l} 
Heating Gross Profit \\
\cline { 2 - 6 }
\end{tabular}

Figure 62: Snapshot of cashflows from the One-Borefield System financial model in Microsoft Excel

\begin{tabular}{|c|c|c|c|c|c|c|c|c|c|c|c|c|}
\hline CASHFLOWS & & 2017 & & 2018 & 2019 & 2020 & 2021 & 2022 & 2023 & 2024 & 2025 & 2026 \\
\hline Cooling Tons & & - & & - & 563 & 563 & 563 & 563 & 563 & 563 & 563 & 563 \\
\hline Cooling Ton hours & & - & & - & $4,787,463$ & $4,787,463$ & $4,787,463$ & $4,787,463$ & $4,787,463$ & $4,787,463$ & $4,787,463$ & $4,787,463$ \\
\hline \multicolumn{13}{|l|}{ Cooling Revenue } \\
\hline Capital Recovery & & . & & - & 29,297 & 29,883 & 30,481 & 31,090 & 31,712 & 32,346 & 32,993 & 33,653 \\
\hline Consumption Charge & & - & & - & 519,060 & 538,099 & 557,899 & 578,492 & 599,908 & 622,181 & 645,345 & 669,435 \\
\hline \multirow[t]{2}{*}{ Fixed Charge } & & - & & - & - & - & - & - & - & - & - & \\
\hline & $\$$ & - & $\$$ & $\$$ & 548,357 & $\$ 567,982$ & $\$ 588,380$ & $\begin{array}{ll}\$ 609,582 \\
\end{array}$ & $\$ \quad 631,620$ & $\$ 654,527$ & $\$ \quad 678,338$ & $\$ 703,088$ \\
\hline \multicolumn{13}{|l|}{ Variable Costs - Cooling } \\
\hline Electricity & & - & & - & 67,173 & 69,853 & 72,639 & 75,536 & 78,550 & 81,683 & 84,942 & 88,331 \\
\hline Water & & - & & - & - & - & - & - & . & - & - & - \\
\hline Chemicals & & - & & - & . & - & - & - & - & - & - & - \\
\hline \multirow[t]{2}{*}{ Total Variable Costs } & $\$$ & - & 5 & - & 67,173 & 69,853 & 72,639 & 75,536 & 78,550 & $\$ \quad 81,683$ & 84,942 & 88,331 \\
\hline & & - & & - & - & - & - & - & - & - & - & - \\
\hline \multirow[t]{3}{*}{ Cooling Gross Profit } & 5 & - & 5 & - & 481,184 & \begin{tabular}{|l|}
$\$ 498,129$ \\
\end{tabular} & $\$ 515,741$ & $\$ 534,045$ & $\$ \quad 553,070$ & $\$ 572,844$ & \begin{tabular}{l|}
593,395 \\
\end{tabular} & S 614,757 \\
\hline & & & & & $87.8 \%$ & 87.796 & 87.796 & $87.6 \%$ & $87.6 \%$ & $87.5 \%$ & $87.5 \%$ & 87.496 \\
\hline & & & & $87.4 \%$ & & & & & & & & \\
\hline Heating MBH & & - & & - & 13,321 & 13,321 & 13,321 & 13,321 & 13,321 & 13,321 & 13,321 & 13,321 \\
\hline Heating MMBtu & & - & & - & 49,849 & 49,849 & 49,849 & 49,849 & 49,849 & 49,849 & 49,849 & 49,849 \\
\hline \multicolumn{13}{|l|}{ Heating Revenue } \\
\hline Capital Recovery & & & & & & 30,004 & 30,604 & 31,216 & 31,840 & 32,477 & 33,127 & 33,789 \\
\hline Consumption Charge & & - & & - & 658,346 & 677,960 & 698,285 & 719,355 & 741,205 & 763,871 & 787,394 & 811,815 \\
\hline \multirow{2}{*}{ Fixed Charge } & & - & & - & - & - & - & - & - & - & - & . \\
\hline & $\$$ & - & s & -5 & 658,346 & $\$ 707,964$ & \$ 728,889 & \$ 750,571 & \$ 773,045 & \$ 796,349 & $\begin{array}{ll}\$ & 820,521\end{array}$ & $\$ 845,604$ \\
\hline
\end{tabular}




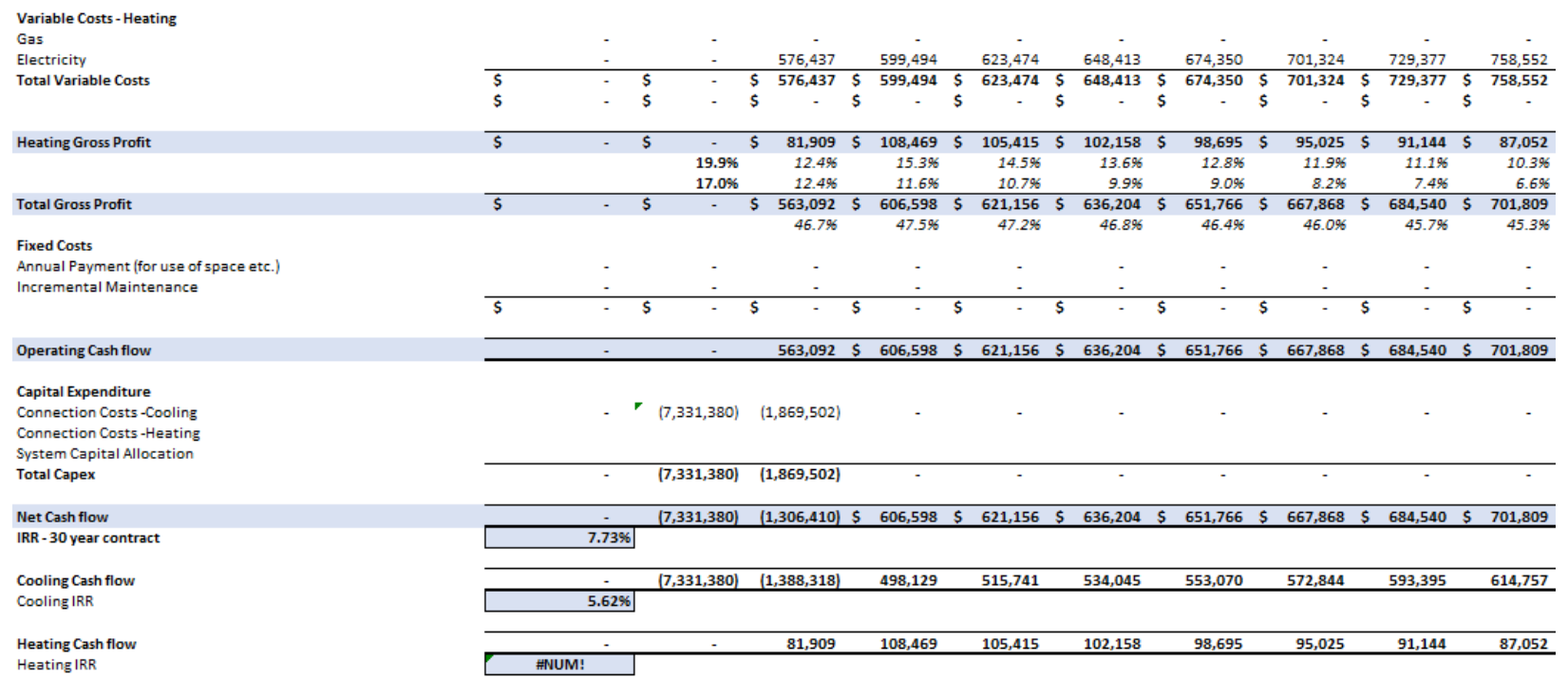

Figure 63: Snapshot of cashflows from the Two-Borefield System financial model in Microsoft Excel

\section{Simulations and Modelling}

\section{GLD}

Figure 64 shows the results from the 20-year hourly GLD simulation of the One-Borefield

Scenario. The seasonal heat pump COP and the number of boreholes required to ensure the peak

inlet temperatures were adequate were used in the financial model.

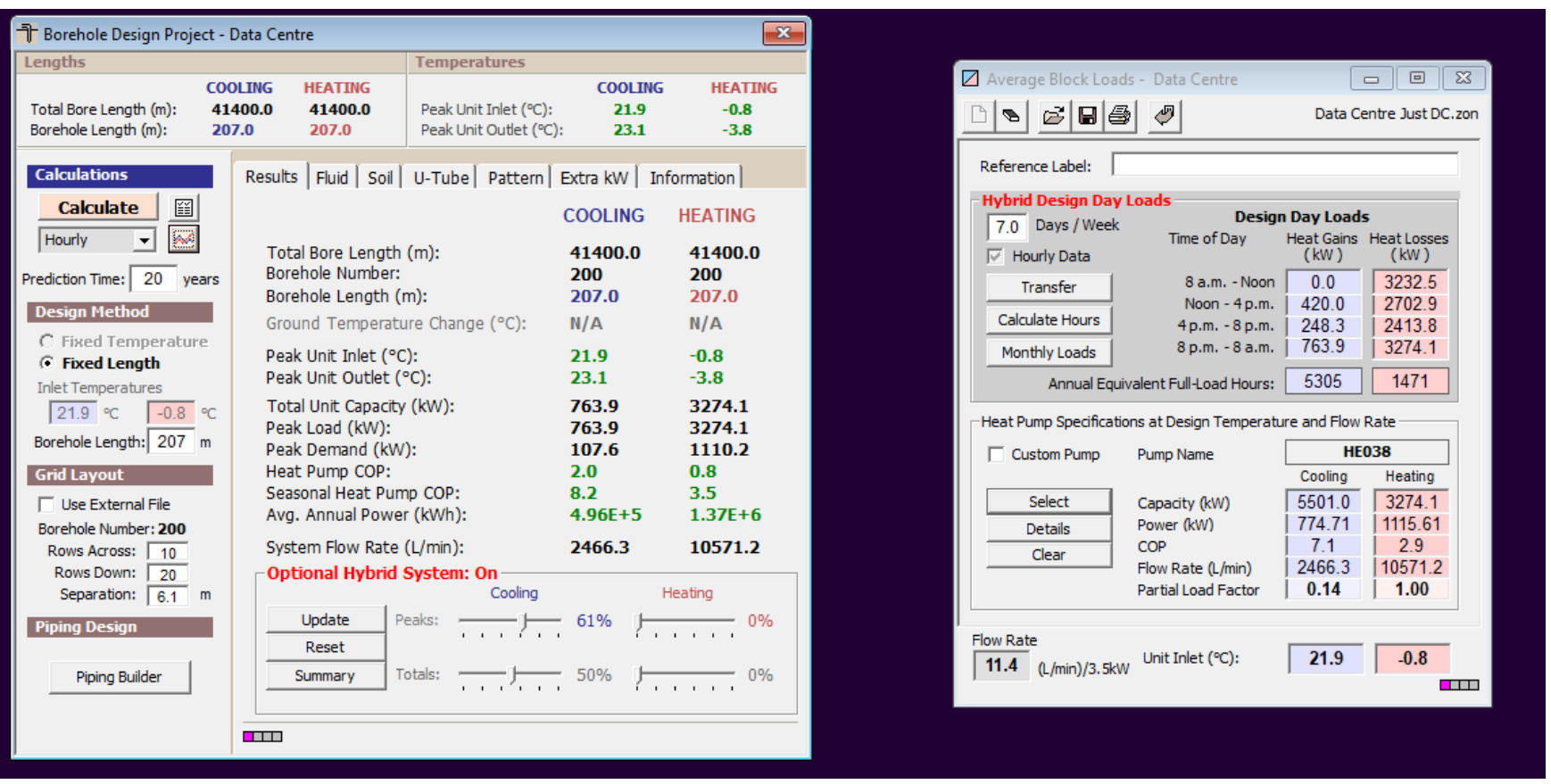

Figure 64: Snapshot of the 20-year hourly GLD simulation results for the One-Borefield System 


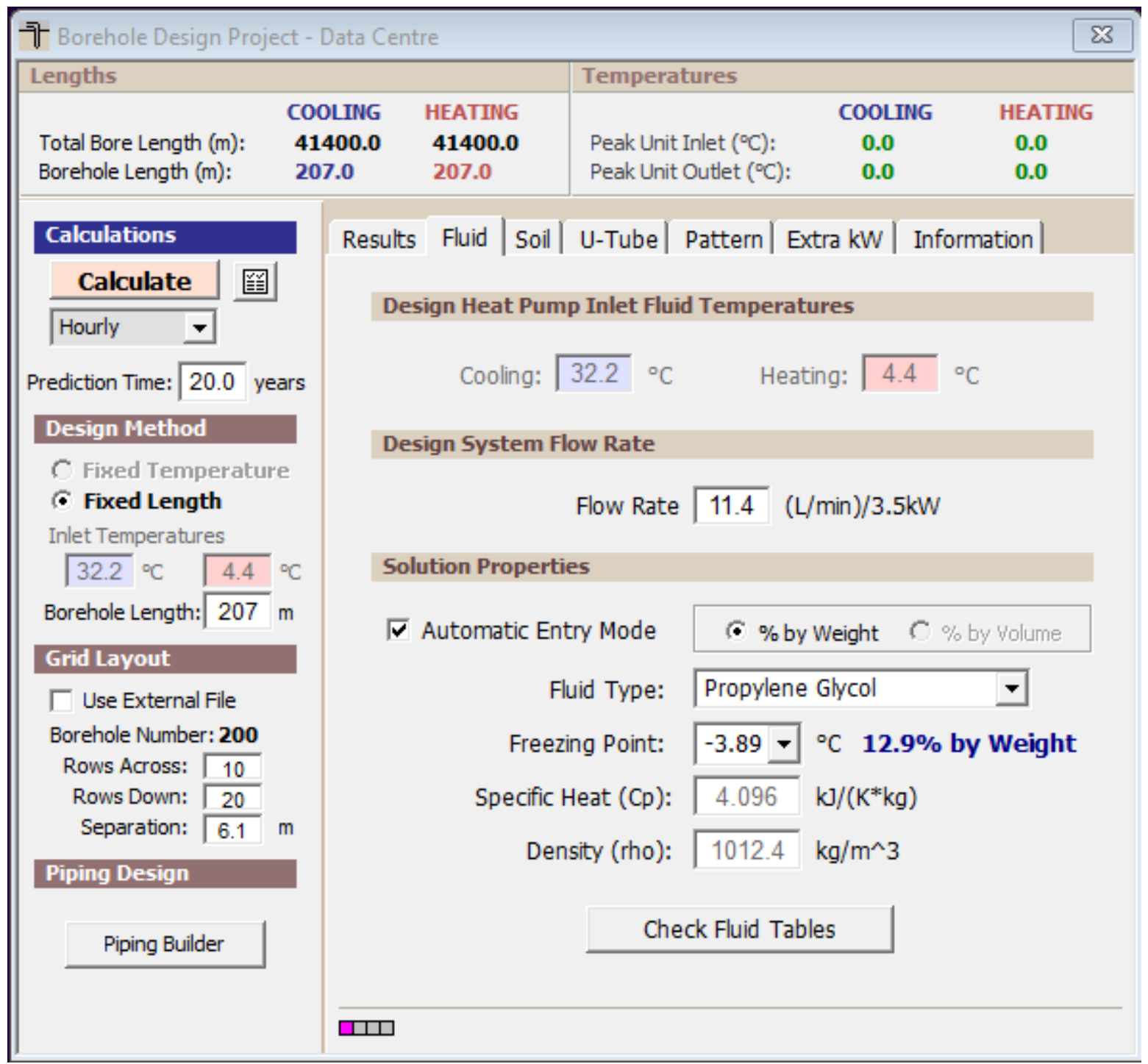

Figure 65: Snapshot of GLD fluid inputs for 20-year simulation 


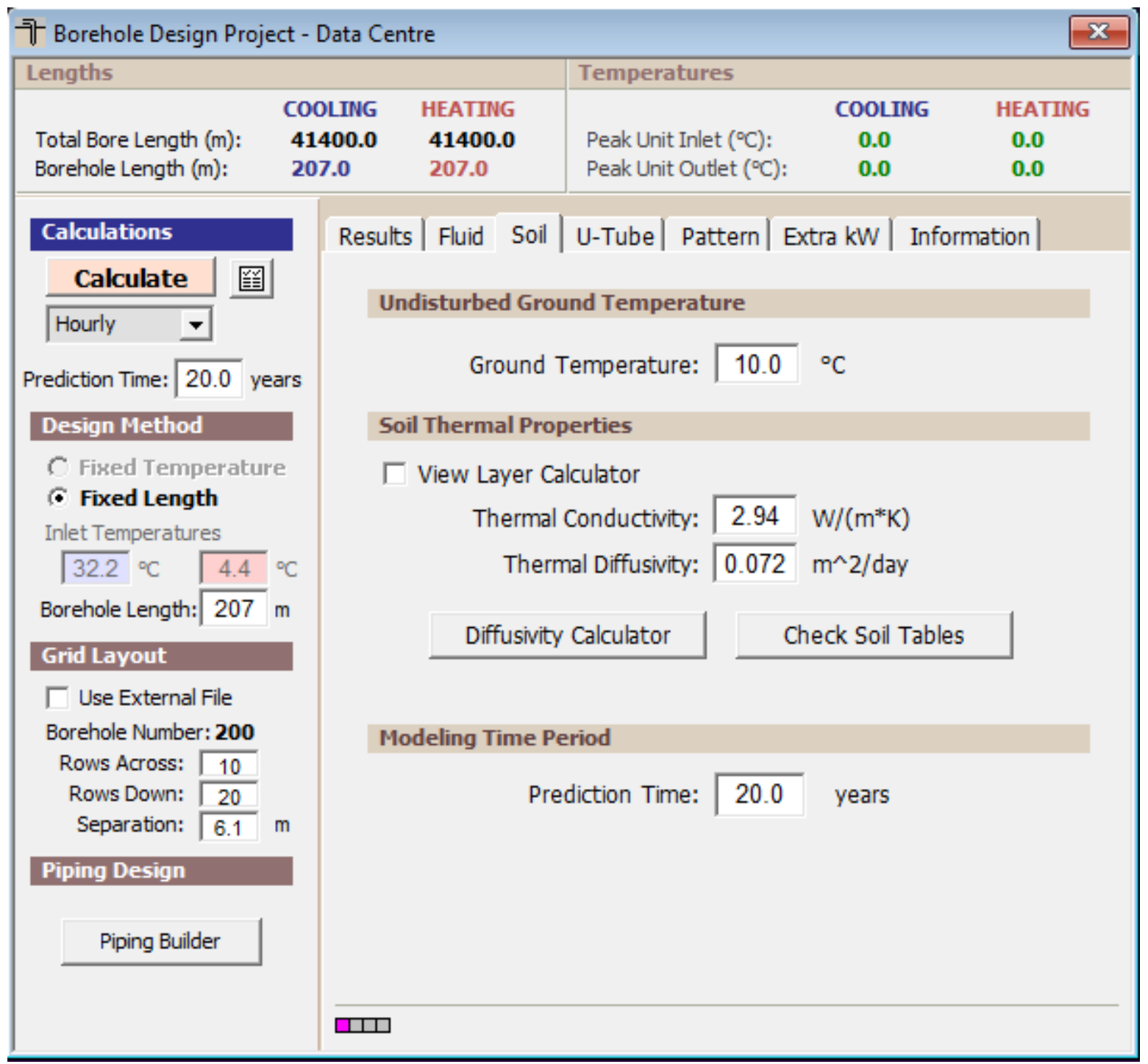

Figure 66: Snapshot of GLD soil inputs for 20-year simulation 


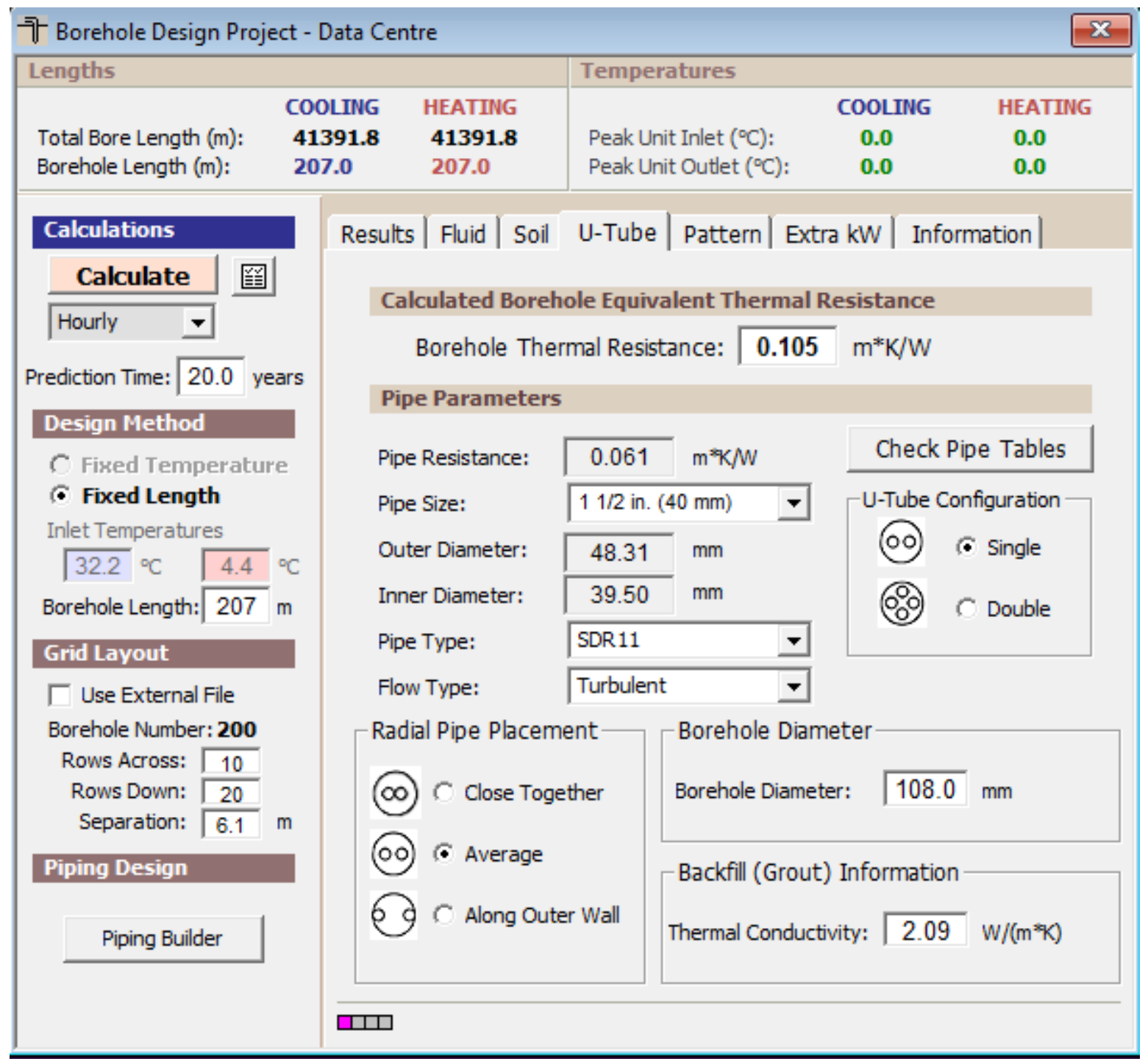

Figure 67: Snapshot of GLD borehole inputs for 20-year simulation 


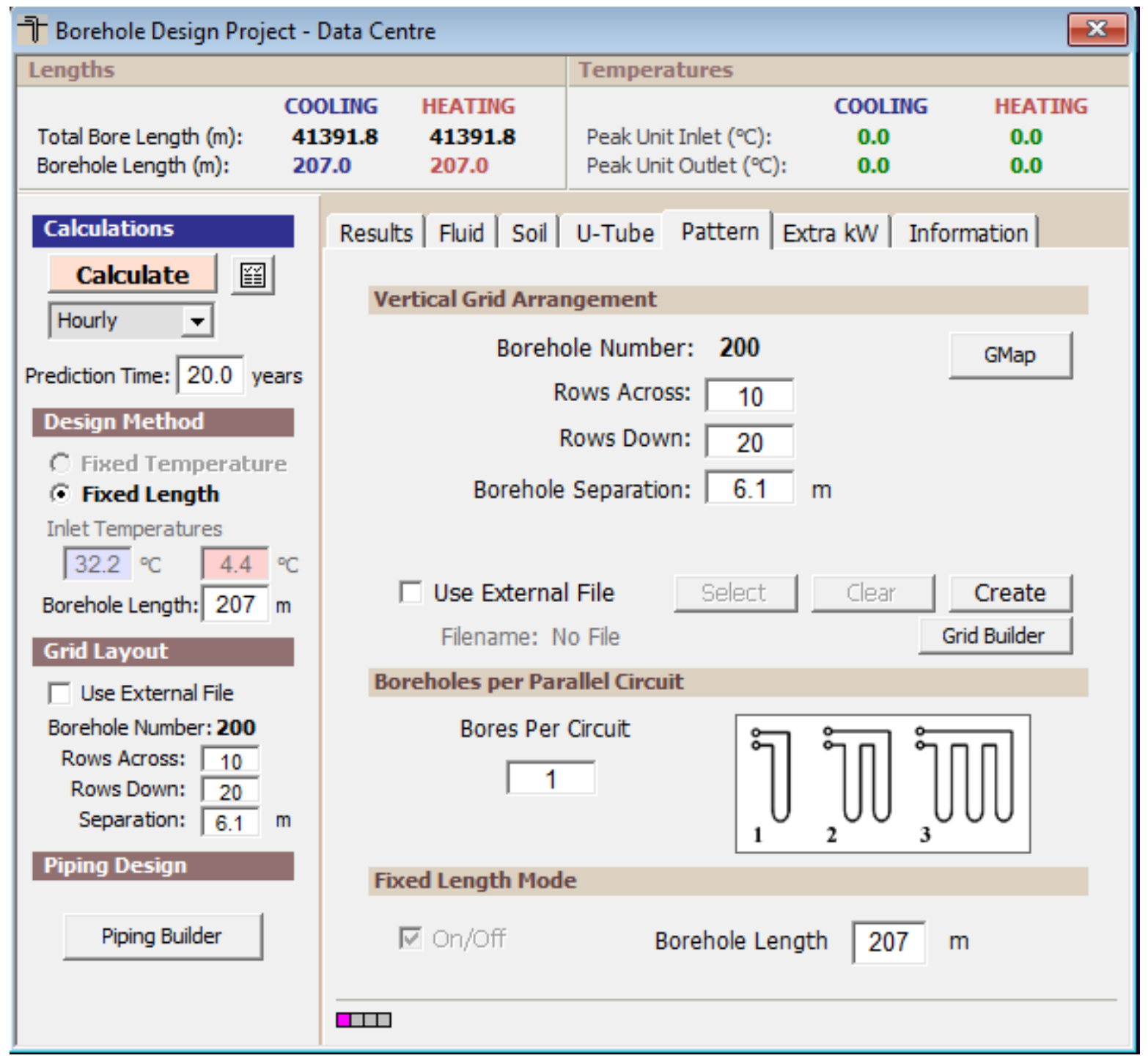

Figure 68: Snapshot of GLD borefield pattern inputs for 20-year simulation

\section{TRNSYS}

Figure 69 shows the TRNSYS model that was generated to simulate the Two-Borefield Scenario.

The model simulated hourly electricity consumption and temperatures, which fed into the financial model. 


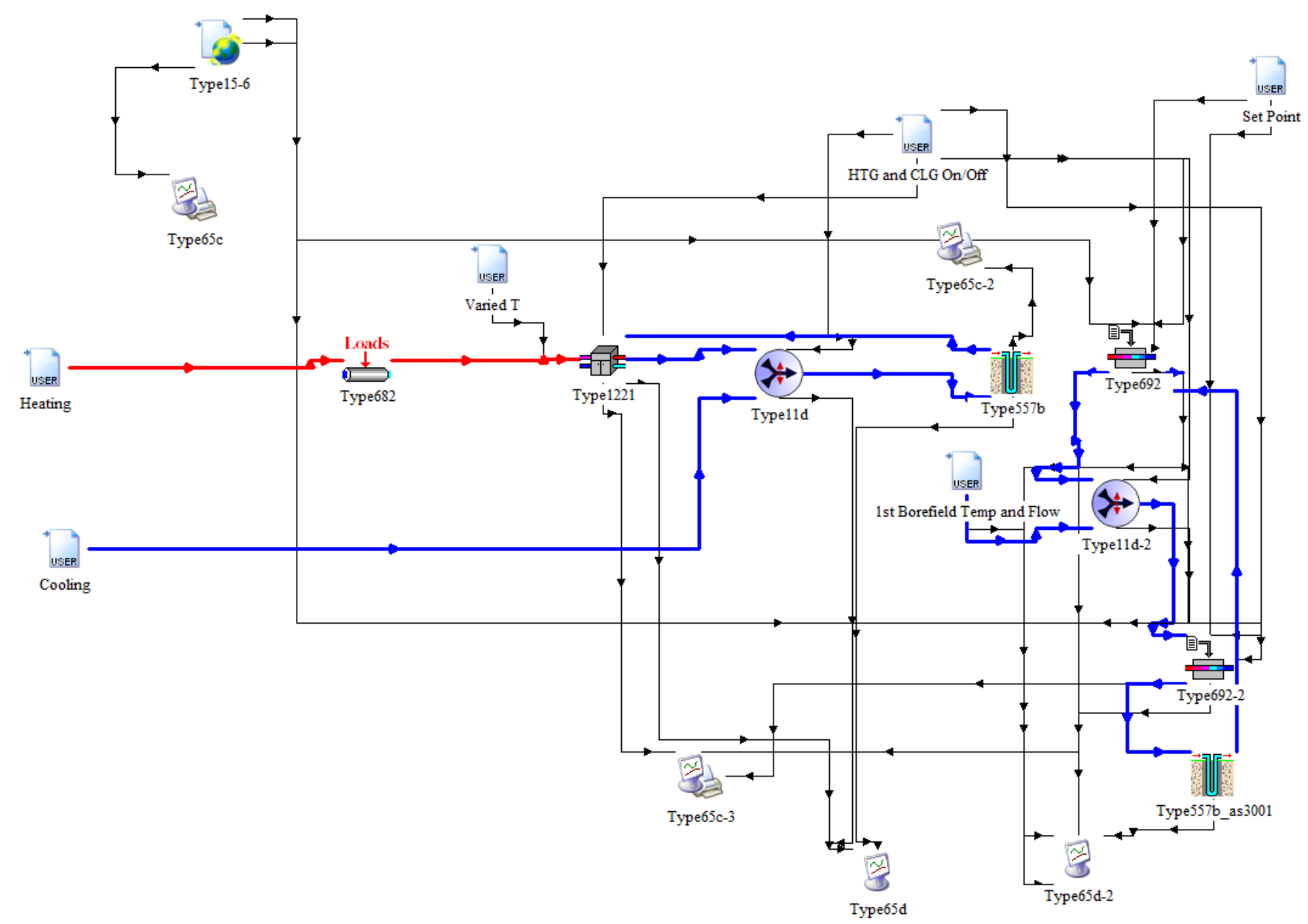

Figure 69: Snapshot of TRNSYS model used to simulate the Two-Borefield System

Table 38: "Hot" borefield input parameters used in the Two-Borefield System simulation

(Two Borefields Just DC Feb 12 10C 16C) Type557b

Parameter Input Output Derivative Special Cards Extemal Files Comment

\begin{tabular}{|c|c|c|c|c|c|c|}
\hline & & Name & Value & Unit & More & Macro \\
\hline 1 & 田 & Storage volume & 1666000 & $\overline{m^{\wedge} 3}$ & More... & $\square$ \\
\hline 2 & 田 & Borehole depth & 207 & $\mathrm{~m}$ & More... & $\square$ \\
\hline 3 & 田 & Header depth & 1.0 & $\mathrm{~m}$ & More... & $\square$ \\
\hline 4 & 田 & Number of boreholes & 250 & - & More... & $\square$ \\
\hline 5 & 田 & Borehole radius & 0.0539 & $\mathrm{~m}$ & More... & $\square$ \\
\hline 6 & 田 & No. of boreholes in series & 1 & - & More... & $\square$ \\
\hline 7 & 田 & Number of radial regions & 1 & - & More... & $\square$ \\
\hline 8 & 田 & Number of vertical regions & 10 & - & More... & $\square$ \\
\hline
\end{tabular}




\begin{tabular}{|c|c|c|c|c|c|c|}
\hline 9 & 固 & Storage thermal conductivity & 10.58 & $\mathrm{~kJ} / \mathrm{hr} \cdot \mathrm{m} . \mathrm{K}$ & More... & $\square$ \\
\hline 10 & 田 & Storage heat capacity & 3528 & $\mathrm{~kJ} / \mathrm{m}^{\wedge} 3 / \mathrm{K}$ & More... & $\square$ \\
\hline 11 & 田 & Fluid to ground resistance & 0.0293 & any & More... & $\square$ \\
\hline 12 & 圆 & $\begin{array}{l}\text { Negative of pipe-to-pipe } \\
\text { resistance }\end{array}$ & 0 & any & More... & $\square$ \\
\hline 13 & 田 & Fluid specific heat & 4.19 & $\mathrm{~kJ} / \mathrm{kg} \cdot \mathrm{K}$ & More... & $\square$ \\
\hline 14 & 圆 & Fluid density & 1000.0 & $\mathrm{~kg} / \mathrm{m}^{\wedge} 3$ & More... & $\square$ \\
\hline 15 & 圆 & Insulation indicator & 0 & - & More... & $\square$ \\
\hline 16 & 回 & Insulation height fraction & 0.5 & - & More... & $\square$ \\
\hline 17 & 田 & Insulation thickness & 0.0254 & $\mathrm{~m}$ & More... & $\square$ \\
\hline 18 & 田 & Insulation thermal conductivity & 10.58 & $\mathrm{~kJ} / \mathrm{hr} \cdot \mathrm{m} . \mathrm{K}$ & More... & $\square$ \\
\hline 19 & 田 & Number of simulation years & 1 & - & More... & $\square$ \\
\hline 20 & 田 & Maximum storage temperature & 100.0 & $\mathrm{C}$ & More... & $\square$ \\
\hline 21 & 田 & $\begin{array}{l}\text { Initial surface temperature of } \\
\text { storage volume }\end{array}$ & 10 & $\mathrm{C}$ & More... & $\square$ \\
\hline 22 & 圆 & $\begin{array}{l}\text { Initial thermal gradient of storage } \\
\text { volume }\end{array}$ & 0.0 & any & More... & $\square$ \\
\hline 23 & 田 & Number of preheating years & 0 & - & More... & $\square$ \\
\hline 24 & 回 & Maximum preheat temperature & 30.0 & $\mathrm{C}$ & More... & $\square$ \\
\hline 25 & (90) & Minimum preheat temperature & 10.0 & $\mathrm{C}$ & More... & $\square$ \\
\hline 26 & 田 & Preheat phase delay & 90 & day & More... & $\square$ \\
\hline 27 & 田 & $\begin{array}{l}\text { Average air temperature - } \\
\text { preheat years }\end{array}$ & 20.0 & $\mathrm{C}$ & More... & $\square$ \\
\hline 28 & 田 & $\begin{array}{l}\text { Amplitude of air temperature - } \\
\text { preheat years }\end{array}$ & 15.0 & deltaC & More... & $\square$ \\
\hline 29 & 田 & $\begin{array}{l}\text { Air temperature phase delay - } \\
\text { preheat years }\end{array}$ & 270 & day & More... & $\square$ \\
\hline 30 & 田 & Number of ground layers & 1 & - & More... & $\square$ \\
\hline 31 & 田 & Thermal conductivity of layer & 10.58 & $\mathrm{~kJ} / \mathrm{hr} \cdot \mathrm{m} . \mathrm{K}$ & More... & $\checkmark$ \\
\hline 32 & 田 & Heat capacity of layer & 3528 & any & More... & $\square$ \\
\hline 33 & 田 & Thickness of layer & 1000 & $\mathrm{~m}$ & More... & $\square$ \\
\hline 34 & 田 & Not used (printing 1) & 0 & - & More... & $\square$ \\
\hline 35 & 圆 & Not used (printing 2) & 0 & - & More... & $\checkmark$ \\
\hline
\end{tabular}


Table 39: Inputs tab of the "hot" borefield for the Two-Borefield System simulation

(Two Borefields Just DC Feb 12 10C 16C) Type557b

\begin{tabular}{|l|l|l|l|l|l} 
Parameter Input & Output Derivative & Special Cards Extemal Files Comment
\end{tabular}

\begin{tabular}{|c|c|c|c|c|c|c|}
\hline & & Name & Value & Unit & More & Macro \\
\hline 1 & 田 & Inlet fluid temperature & 4 & C & More... & $\square$ \\
\hline 2 & 田 & Inlet flowrate (total) & 192000 & $\mathrm{~kg} / \mathrm{hr}$ & More... & $\square$ \\
\hline 3 & 田 & Temperature on top of storage & 10 & $\mathrm{C}$ & More... & $\square$ \\
\hline 4 & 田 & Air temperature & 10 & C & More... & $\square$ \\
\hline 5 & 田 & Circulation switch & 1 & - & More... & $\square$ \\
\hline
\end{tabular}

Table 40: "Cold" borefield input parameters used in the Two-Borefield System simulation

(Two Borefields Just DC Feb 12 10C 16C) Type557b_as3001

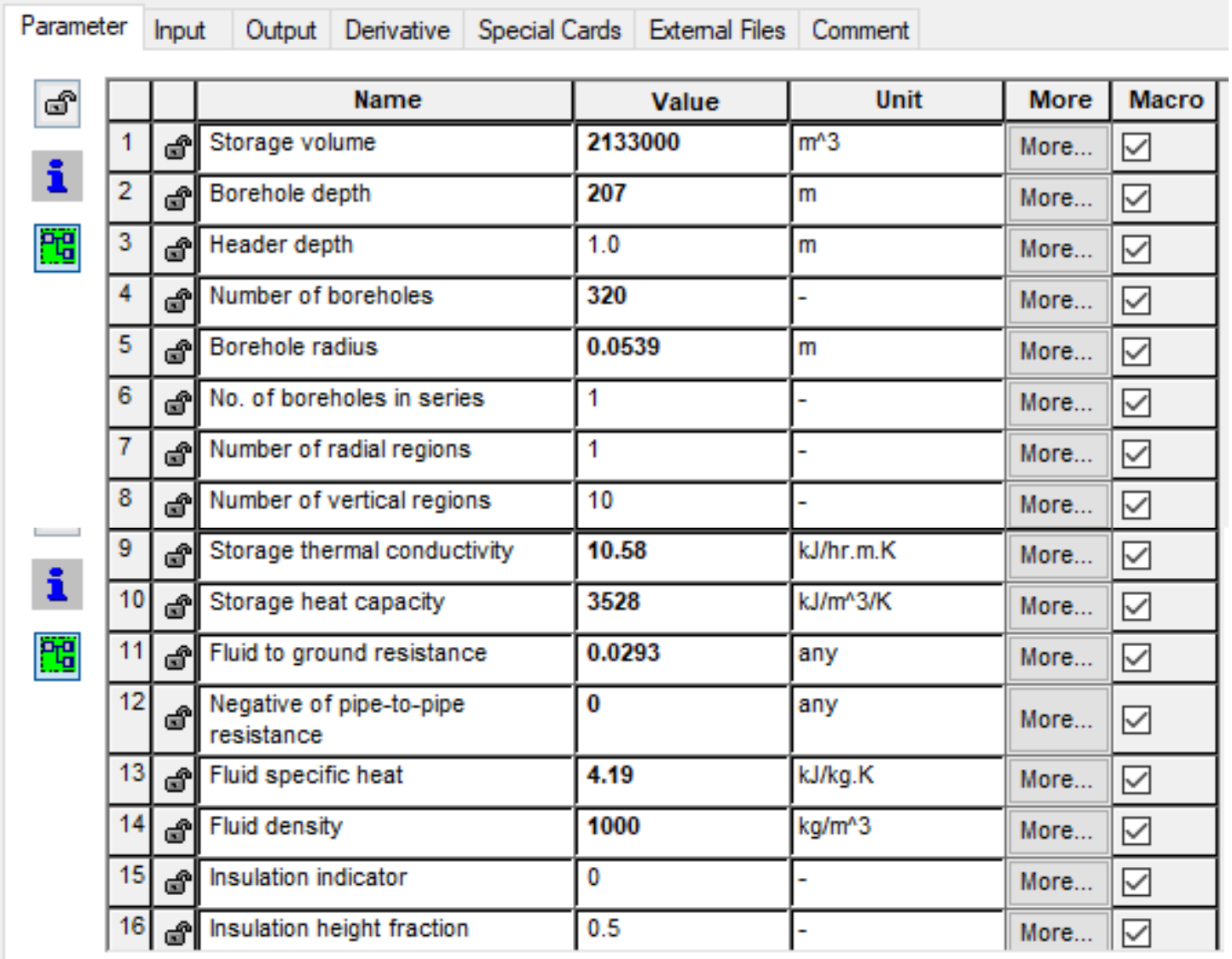




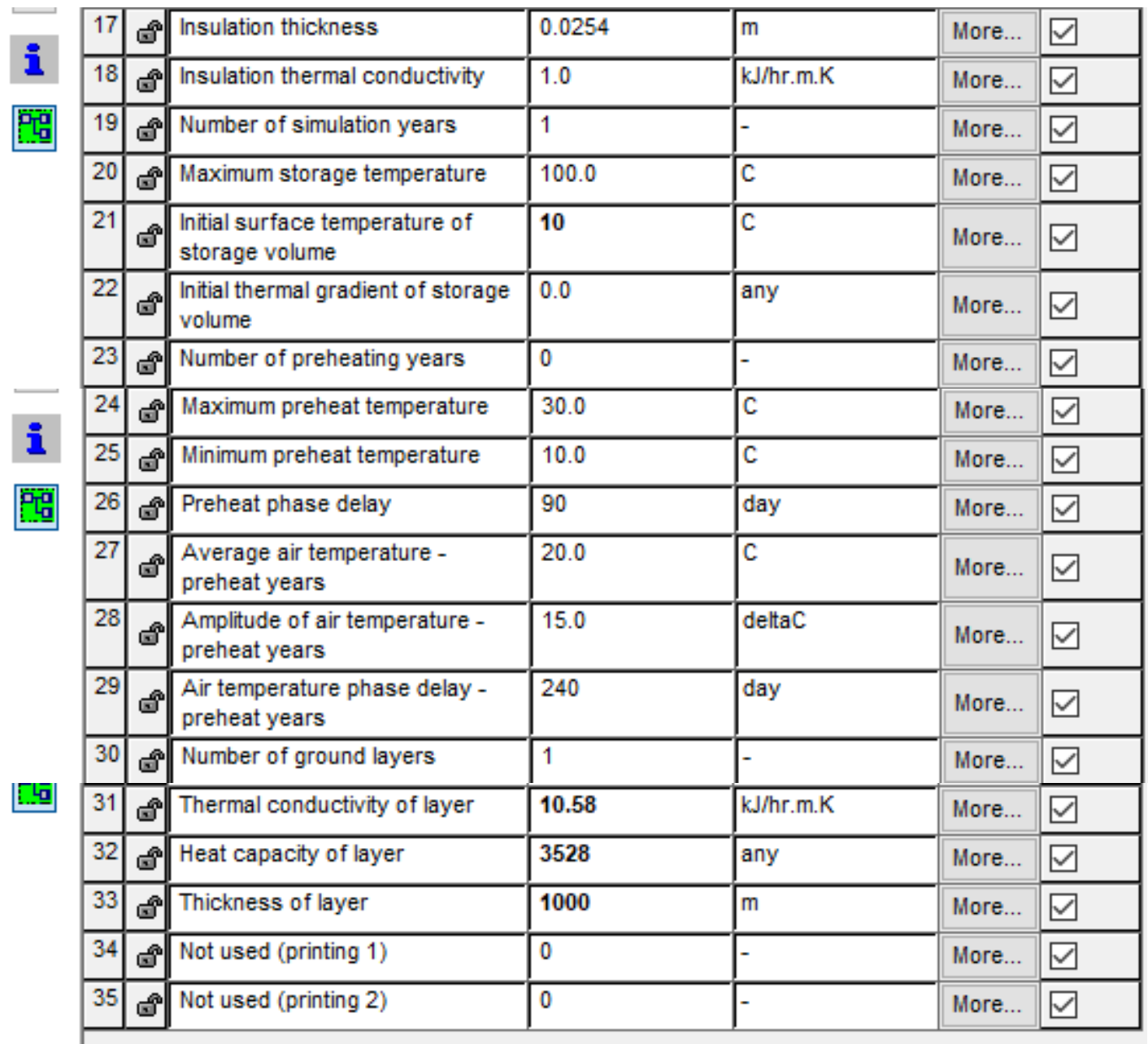

Table 41: Inputs tab of the "cold" borefield for the Two-Borefield System simulation

(Two Borefields Just DC Feb 12 10C 16C) Type557b_as3001

\begin{tabular}{|c|c|c|c|c|c|c|c|c|c|}
\hline \multicolumn{2}{|c|}{ Parameter } & Input & Output & Derivative & Special Cards & Extemal Files & \multicolumn{3}{|l|}{ Comment } \\
\hline \multirow[t]{2}{*}{ 田 } & & & \multicolumn{3}{|c|}{ Name } & Value & Unit & More & Macro \\
\hline & 1 & 田 & Inlet fluid te & mperature & 5 & & C & More... & $\square$ \\
\hline I & 2 & (90) & Inlet flowra & te (total) & 3330 & & $\mathrm{~kg} / \mathrm{hr}$ & More... & $\square$ \\
\hline \multirow[t]{3}{*}{\begin{tabular}{|l|l} 
㧽 \\
\end{tabular}} & 3 & (90) & Temperatur & e on top of s & torage & & C & More... & $\square$ \\
\hline & 4 & (0) & Air temper: & ture & 10 & & C & More... & $\square$ \\
\hline & 5 & 田 & Circulation & switch & -1 & & - & More... & $\square$ \\
\hline
\end{tabular}


Table 42: Input parameters for the two-stage water to water heat pump connected to the "hot" borefield used in the Two-Borefield System simulation

(Two Borefields Just DC Feb 12 10C 16C) Type1221

\begin{tabular}{|c|c|c|c|c|c|c|c|}
\hline \multicolumn{2}{|c|}{ Parameter } & Input & Output Derivative Special $C_{2}$ & Extemal Files & \multicolumn{3}{|l|}{ Comment } \\
\hline \multirow{2}{*}{ 四 } & & \multicolumn{2}{|r|}{ Name } & Value & Unit & More & Macro \\
\hline & 1 & 田 & Source fluid specific heat & 4.190 & $\mathrm{~kJ} / \mathrm{kg} \cdot \mathrm{K}$ & More... & $\square$ \\
\hline 2 & 2 & 固 & Load fluid specific heat & 4.190 & $\mathrm{~kJ} / \mathrm{kg} . \mathrm{K}$ & More... & $\checkmark$ \\
\hline \multirow[t]{5}{*}{ 跑 } & 3 & 回 & Source fluid density & 1000 & $\mathrm{~kg} / \mathrm{m}^{\wedge} 3$ & More... & $\checkmark$ \\
\hline & 4 & 田 & Load fluid density & 1000. & $\mathrm{~kg} / \mathrm{m}^{\wedge} 3$ & More... & $\square$ \\
\hline & 5 & 㘣 & $\begin{array}{l}\text { Logical unit number for 1st stage } \\
\text { cooling data file }\end{array}$ & 30 & - & More... & $\checkmark$ \\
\hline & 6 & 田 & $\begin{array}{l}\text { Logical unit number for } 2 \text { nd stage } \\
\text { cooling data file }\end{array}$ & 31 & - & More... & $\checkmark$ \\
\hline & 7 & 田 & $\begin{array}{l}\text { Number of source temperatures - } \\
\text { cooling }\end{array}$ & 8 & - & More... & $\checkmark$ \\
\hline \multirow{7}{*}{ 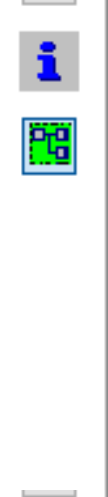 } & 8 & 田 & $\begin{array}{l}\text { Number of load temperatures - } \\
\text { cooling }\end{array}$ & 4 & - & More... & $\square$ \\
\hline & 9 & 田 & $\begin{array}{l}\text { Logical unit for 1st stage heating } \\
\text { data }\end{array}$ & 32 & - & More... & $\square$ \\
\hline & 10 & $\mathrm{\theta}$ & $\begin{array}{l}\text { Logical unit for } 2 \text { nd stage heating } \\
\text { data }\end{array}$ & 33 & - & More... & $\square$ \\
\hline & 11 & 圆 & $\begin{array}{l}\text { Number of source temps. - } \\
\text { heating }\end{array}$ & 6 & - & More... & $\square$ \\
\hline & 12 & 圆 & Number of load temps. - heating & 4 & - & More... & $\square$ \\
\hline & 13 & 田 & Number of source flow rates & 3 & - & More... & $\square$ \\
\hline & 14 & 圆 & Number of load flow rates & 3 & - & More... & $\square$ \\
\hline \multirow{6}{*}{$\begin{array}{l}3 \\
2\end{array}$} & 15 & 圆 & $\begin{array}{l}\text { Rated 1st stage cooling capacity } \\
\text { per heat pump }\end{array}$ & 10000000 & $\mathrm{~kJ} / \mathrm{hr}$ & More... & $\square$ \\
\hline & 16 & 固 & $\begin{array}{l}\text { Rated 2nd stage cooling capacity } \\
\text { per heat pump }\end{array}$ & 10000000 & $\mathrm{~kJ} / \mathrm{hr}$ & More... & $\square$ \\
\hline & 17 & 司 & $\begin{array}{l}\text { Rated 1st stage cooling power } \\
\text { per heat pump }\end{array}$ & 2000000 & $\mathrm{~kJ} / \mathrm{hr}$ & More... & $\square$ \\
\hline & 18 & 四 & $\begin{array}{l}\text { Rated } 2 \text { nd stage cooling power } \\
\text { per heat pump }\end{array}$ & 2000000 & $\mathrm{~kJ} / \mathrm{hr}$ & More... & $\square$ \\
\hline & 19 & 圆 & $\begin{array}{l}\text { Rated 1st stage heating capacity } \\
\text { per heat pump }\end{array}$ & 10000000 & $\mathrm{~kJ} / \mathrm{hr}$ & More... & $\square$ \\
\hline & 20 & | & $\begin{array}{l}\text { Rated 2nd stage heating capacity } \\
\text { per heat pump }\end{array}$ & 10000000 & $\mathrm{~kJ} / \mathrm{hr}$ & More... & $\square$ \\
\hline
\end{tabular}




\begin{tabular}{|c|c|c|c|c|c|c|}
\hline 21 & 固 & $\begin{array}{l}\text { Rated 1st stage heating power } \\
\text { per heat pump }\end{array}$ & 2000000 & $\mathrm{~kJ} / \mathrm{hr}$ & More... & $\square$ \\
\hline 22 & 田 & $\begin{array}{l}\text { Rated } 2 \text { nd stage heating power } \\
\text { per heat pump }\end{array}$ & 2000000 & $\mathrm{~kJ} / \mathrm{hr}$ & More... & $\square$ \\
\hline 23 & 田 & $\begin{array}{l}\text { Rated 1st stage source flow rate } \\
\text { per heat pump }\end{array}$ & 65 & Vs & More... & $\square$ \\
\hline 24 & 田 & $\begin{array}{l}\text { Rated } 2 \text { nd stage source flow } \\
\text { rate per heat pump }\end{array}$ & 65 & Vs & More... & $\square$ \\
\hline 25 & 圆 & $\begin{array}{l}\text { Rated 1st stage load flow rate } \\
\text { per heat pump }\end{array}$ & 65 & Vs & More... & $\checkmark$ \\
\hline 26 & 田 & $\begin{array}{l}\text { Rated 2nd stage load flow rate } \\
\text { per heat pump }\end{array}$ & 65 & Vs & More... & $\square$ \\
\hline 27 & 圆 & Number of identical heat pumps & 1 & - & More... & $\square$ \\
\hline
\end{tabular}

Table 43: Input parameters for dry cooler which operates during the winter, used in the Two-Borefield System simulation

(Two Borefields Just DC Feb 12 10C 16C) Type692

Parameter Input Output Derivative Special Cards Extemal Files Comment

\begin{tabular}{|c|c|c|c|c|c|c|}
\hline & & Name & Value & Unit & More & Macro \\
\hline 1 & 田 & Logical unit - performance data & 64 & - & More... & $\square$ \\
\hline 2 & 㘣 & Number of sink temperatures & 13 & - & More... & $\square$ \\
\hline 3 & 田 & Number of inlet fluid temperatures & 9 & - & More... & $\square$ \\
\hline 4 & 圆 & Fluid specific heat & 4.190 & $\mathrm{~kJ} / \mathrm{kg} \cdot \mathrm{K}$ & More... & $\square$ \\
\hline
\end{tabular}

(Two Borefields Just DC Feb 12 10C 16C) Type692

Parameter Input Output Derivative Special Cards Extemal Files Comment

\begin{tabular}{|c|c|c|c|c|c|c|}
\hline & & Name & Value & Unit & More & Macro \\
\hline 1 & 田 & Inlet fluid temperature & 13 & C & More... & $\square$ \\
\hline 2 & 田 & Inlet flow rate & 500000 & $\mathrm{~kg} / \mathrm{hr}$ & More... & $\square$ \\
\hline 3 & 田 & Sink temperature & 10 & C & More... & $\square$ \\
\hline 4 & 田 & Set point temperature & 10 & $\mathrm{C}$ & More... & $\square$ \\
\hline 5 & 田 & Control signal & 1.0 & - & More... & $\square$ \\
\hline
\end{tabular}


Table 44: Input parameters for dry cooler which operates during the shoulder seasons, used in the Two-Borefield System simulation

(Two Borefields Just DC Feb 12 10C 16C) Type692-2

\begin{tabular}{|l|l|l|l|l|l} 
Parameter Input & Output & Derivative & Special Cards & Extemal Files & Comment
\end{tabular}

\begin{tabular}{|c|c|c|c|c|c|c|}
\hline & & Name & Value & Unit & More & Macro \\
\hline 1 & 煦 & Logical unit - performance data & 66 & - & More... & $\square$ \\
\hline 2 & 田 & Number of sink temperatures & 13 & - & More... & $\square$ \\
\hline 3 & 田 & Number of inlet fluid temperatures & 9 & - & More... & $\square$ \\
\hline 4 & 田 & Fluid specific heat & 4.190 & $\mathrm{~kJ} / \mathrm{kg} \cdot \mathrm{K}$ & More... & $\square$ \\
\hline
\end{tabular}

(Two Borefields Just DC Feb 12 10C 16C) Type692-2

Parameter Input Output Derivative Special Cards Extemal Files Comment

\begin{tabular}{|c|c|c|c|c|c|c|}
\hline & & Name & Value & Unit & More & Macro \\
\hline 1 & 田 & Inlet fluid temperature & 13 & C & More... & $\square$ \\
\hline 2 & 囷 & Inlet flow rate & 333000 & $\mathrm{~kg} / \mathrm{hr}$ & More... & $\square$ \\
\hline 3 & 田 & Sink temperature & 10 & C & More... & $\square$ \\
\hline 4 & 囫 & Set point temperature & 10 & C & More... & $\square$ \\
\hline 5 & 田 & Control signal & 1.0 & - & \begin{tabular}{|l|} 
More... \\
\end{tabular} & $\nabla$ \\
\hline
\end{tabular}

\begin{tabular}{|c|c|c|c|c|c|c|c|c|c|c|c|}
\hline & \multicolumn{10}{|c|}{ Sink Temperatures $\left({ }^{\circ} \mathrm{C}\right)$} \\
\hline & & \multicolumn{2}{|l|}{-25} & \multicolumn{2}{|l|}{-20} & \multicolumn{2}{|l|}{-15} & \multicolumn{2}{|l|}{-10} & \multicolumn{2}{|l|}{-5} \\
\hline & & $\begin{array}{l}\text { Capacity } \\
\text { (kJ) }\end{array}$ & COP & $\begin{array}{l}\text { Capacity } \\
\text { (kJ) }\end{array}$ & COP & $\begin{array}{l}\text { Capacity } \\
\text { (kJ) }\end{array}$ & COP & $\begin{array}{l}\text { Capacity } \\
\text { (kJ) }\end{array}$ & COP & $\begin{array}{l}\text { Capacity } \\
\text { (kJ) }\end{array}$ & COP \\
\hline \multirow{8}{*}{ 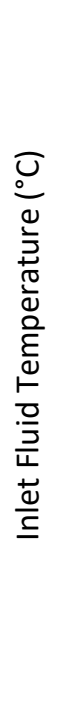 } & -20 & $25,000,000$ & 50 & 500 & 0 & 500 & 0 & 500 & 0 & 500 & 0 \\
\hline & -15 & $25,000,000$ & 50 & $25,000,000$ & 50 & 500 & 0 & 500 & 0 & 500 & 0 \\
\hline & -10 & $25,000,000$ & 50 & $25,000,000$ & 50 & $10,000,000$ & 20 & 5,000 & 0 & 5,000 & 0 \\
\hline & -5 & $25,000,000$ & 50 & $25,000,000$ & 50 & $10,000,000$ & 20 & 5,000 & 0 & 5,000 & 0 \\
\hline & 0 & $25,000,000$ & 50 & $25,000,000$ & 50 & $18,500,000$ & 37 & $10,000,000$ & 20 & 5,000 & 0 \\
\hline & 5 & $25,000,000$ & 50 & $25,000,000$ & 50 & $18,500,000$ & 37 & $25,000,000$ & 50 & $10,000,000$ & 20 \\
\hline & 10 & $37,500,000$ & 75 & $37,500,000$ & 75 & $25,000,000$ & 50 & $10,000,000$ & 20 & $10,000,000$ & 20 \\
\hline & 15 & $37,500,000$ & 75 & $37,500,000$ & 75 & $50,000,000$ & 100 & $25,000,000$ & 50 & $25,000,000$ & 50 \\
\hline
\end{tabular}




\begin{tabular}{|c|c|c|c|c|c|c|c|c|c|c|c|}
\hline & \multicolumn{10}{|c|}{ Sink Temperatures $\left({ }^{\circ} \mathrm{C}\right)$} \\
\hline & & \multicolumn{2}{|l|}{-25} & \multicolumn{2}{|l|}{-20} & \multicolumn{2}{|l|}{-15} & \multicolumn{2}{|l|}{-10} & \multicolumn{2}{|l|}{-5} \\
\hline & & $\begin{array}{l}\text { Capacity } \\
\text { (kJ) }\end{array}$ & COP & $\begin{array}{l}\text { Capacity } \\
\text { (kJ) }\end{array}$ & COP & $\begin{array}{l}\text { Capacity } \\
\text { (kJ) }\end{array}$ & COP & $\begin{array}{l}\text { Capacity } \\
\text { (kJ) }\end{array}$ & COP & $\begin{array}{l}\text { Capacity } \\
\text { (kJ) }\end{array}$ & COP \\
\hline \multirow{8}{*}{ 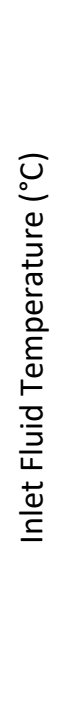 } & -20 & $25,000,000$ & 50 & 500 & 0 & 500 & 0 & 500 & 0 & 500 & 0 \\
\hline & -15 & $25,000,000$ & 50 & $25,000,000$ & 50 & 500 & 0 & 500 & 0 & 500 & 0 \\
\hline & -10 & $25,000,000$ & 50 & $25,000,000$ & 50 & $10,000,000$ & 20 & 5,000 & 0 & 5,000 & 0 \\
\hline & -5 & $25,000,000$ & 50 & $25,000,000$ & 50 & $10,000,000$ & 20 & 5,000 & 0 & 5,000 & 0 \\
\hline & 0 & $25,000,000$ & 50 & $25,000,000$ & 50 & $18,500,000$ & 37 & $10,000,000$ & 20 & 5,000 & 0 \\
\hline & 5 & $25,000,000$ & 50 & $25,000,000$ & 50 & $18,500,000$ & 37 & $25,000,000$ & 50 & $10,000,000$ & 20 \\
\hline & 10 & $37,500,000$ & 75 & $37,500,000$ & 75 & $25,000,000$ & 50 & $10,000,000$ & 20 & $10,000,000$ & 20 \\
\hline & 15 & $37,500,000$ & 75 & $37,500,000$ & 75 & $50,000,000$ & 100 & $25,000,000$ & 50 & $25,000,000$ & 50 \\
\hline
\end{tabular}

\begin{tabular}{|c|c|c|c|c|c|c|c|c|c|c|c|}
\hline & \multicolumn{10}{|c|}{ Sink Temperatures $\left({ }^{\circ} \mathrm{C}\right)$} \\
\hline & & \multicolumn{2}{|l|}{0} & \multicolumn{2}{|l|}{5} & \multicolumn{2}{|c|}{10} & \multicolumn{2}{|c|}{15} & \multicolumn{2}{|c|}{20} \\
\hline & & $\begin{array}{l}\text { Capacity } \\
(\mathrm{kJ})\end{array}$ & COP & $\begin{array}{l}\text { Capacity } \\
(\mathrm{kJ})\end{array}$ & COP & $\begin{array}{l}\text { Capacity } \\
\text { (kJ) }\end{array}$ & COP & $\begin{array}{l}\text { Capacity } \\
(\mathrm{kJ})\end{array}$ & $\mathrm{COP}$ & $\begin{array}{l}\text { Capacity } \\
\text { (kJ) }\end{array}$ & COP \\
\hline \multirow{8}{*}{ 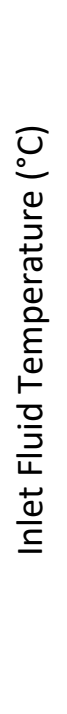 } & -20 & 500 & 0 & 500 & 0 & 500 & 0 & 500 & 0 & 500 & 0 \\
\hline & -15 & 500 & 0 & 500 & 0 & 500 & 0 & 500 & 0 & 500 & 0 \\
\hline & -10 & 5,000 & 0 & 5,000 & 0 & 5,000 & 0 & 500 & 0 & 500 & 0 \\
\hline & -5 & 5,000 & 0 & 5,000 & 0 & 5,000 & 0 & 500 & 0 & 500 & 0 \\
\hline & 0 & 5,000 & 0 & 5,000 & 0 & 5,000 & 0 & 500 & 0 & 500 & 0 \\
\hline & 5 & 5,000 & 0 & 5,000 & 0 & 5,000 & 0 & 500 & 0 & 500 & 0 \\
\hline & 10 & $10,000,000$ & 20 & $5,000,000$ & 10 & 5,000 & 0 & 500 & 0 & 500 & 0 \\
\hline & 15 & $25,000,000$ & 50 & $10,000,000$ & 20 & $5,000,000$ & 10 & 500 & 0 & 500 & 0 \\
\hline
\end{tabular}


Table 45: Weather input parameters used in the Two-Borefield System simulation

(Two Borefields Just DC Feb 12 10C 16C) Type15-6

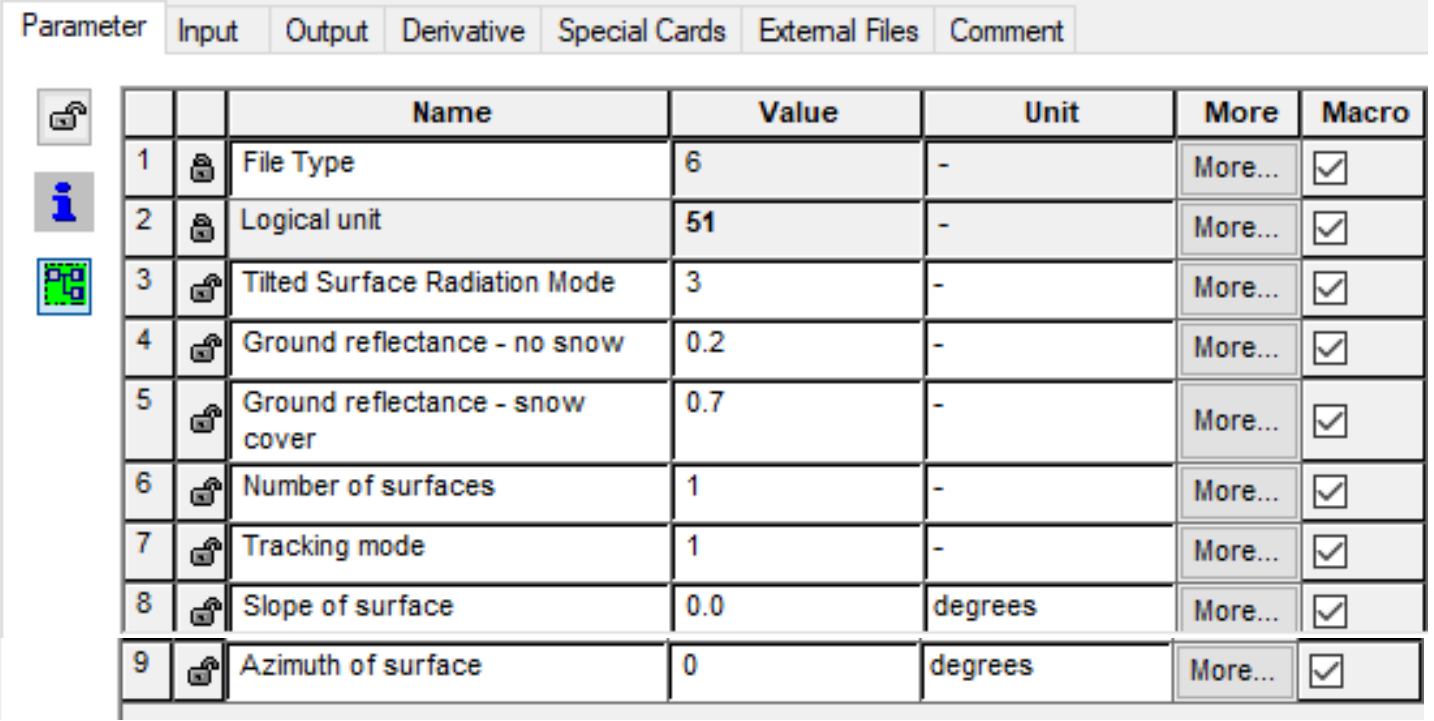

